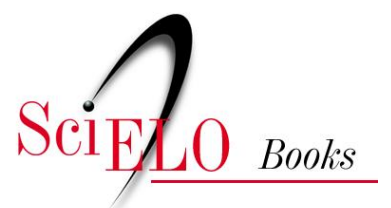

\title{
Fundamentos da vigilância sanitária
}

\author{
Suely Rozenfeld (org.)
}

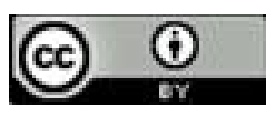

All the contents of this work, except where otherwise noted, is licensed under a Creative Commons Attribution 4.0 International license.

Todo o conteúdo deste trabalho, exceto quando houver ressalva, é publicado sob a licença Creative Commons Atribição 4.0.

Todo el contenido de esta obra, excepto donde se indique lo contrario, está bajo licencia de la licencia Creative Commons $\underline{\text { Reconocimento } 4.0 .}$. 


\section{FUNDAMENTOS DA VIGILÂNCIA SANITÁRIA}




\section{FUNDAÇÃO OSWALDO CRUZ}

Presidente

Paulo Gadelha

Vice-Presidente de Ensino, Informação e Comunicação

Maria do Carmo Leal

\section{EDITORA FIOCRUZ}

Diretora

Maria do Carmo Leal

Editor Executivo

João Carlos Canossa Mendes

Editores Científicos

Nísia Trindade Lima e Ricardo Ventura Santos

Conselho Editorial

Ana Lúcia Teles Rabello

Armando de Oliveira Schubach

Carlos E. A. Coimbra Jr.

Gerson Oliveira Penna

Gilberto Hochman

Joseli Lannes Vieira

Ligia Vieira da Silva

Maria Cecília de Souza Minayo 


\section{FUNDAMENTOS DA VIGILÂNCIA SANITÁRIA}

Suely Rozenfeld organizadora

6² reimpressão

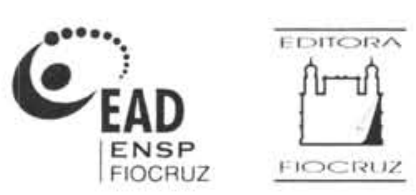


Copyright (c) 2000 dos Autores

Todos os direitos desta edição reservados à

Fundação Oswaldo Cruz / Editora

ISBN: 85-85676-73-6

1" edição: 2000

1" reimpressão: 2001

$2^{\circ}$ reimpressão: 2003

$3^{\mathrm{a}}$ reimpressão: 2004

4" reimpressão: 2005

5" reimpressão: 2006

$6^{a}$ reimpressão: 2009

Projeto Gráfico

Danowski Design Ltda.

e Adriana Cataldo

Preparação de originais e copidesque

Marcos Fernandes da Silva Moreira

Digitação final

Lauro Monteiro Damasceno

Revisão técnica

Suely Rozenfeld

Catalogação-na-fonte

Centro de Informação Científica e Tecnológica

Biblioteca Lincoln de Freitas Filho

R893f Rozenfeld, Suely (org.)

Fundamentos da Vigilância Sanitária. / Organizado por

Suely Rozenfeld. - Rio de Janeiro : Editora FIOCRUZ, 2000.

301p.

1.Vigilância Sanitária. 2.Vigilância Epidemiológica.

3. SUS (BR).

CDD - 20.ed. - 614.42

\section{9}

EDITORA FIOCRUZ

Av. Brasil, 4036, $1^{\circ}$ andar, sala 112, Manguinhos

21040-361, Rio de Janeiro, RJ

Tels.: (21) 3882-9039 e 3882-9007

Telefax: (21) 3882-9006

e-mail: editora@fiocruz.br

www.fiocruz.br/editora 


\section{Ana Célia Pessoa da Silva}

Departamento de Administração e Planejamento em Saúde Escola Nacional de Saúde Pública/Fundação Oswaldo Cruz anacelia@ensp.fiocruz.br

\section{Ana Luiza Villasbôas}

Instituto de Saúde Coletiva/Universidade Federal da Bahia analuv@ufba.br

\section{Carmen Fontes Teixeira}

Instituto de Saúde Coletiva/Universidade Federal da Bahia carment@ufba.br

\section{Ediná Alves Costa}

Instituto de Saúde Coletiva/Universidade Federal da Bahia edina@ufba.br

\section{Guido Palmeira}

Departamento de Epidemiologia e Métodos Quantitativos em Saúde Escola Nacional de Saúde Pública/Fundação Oswaldo Cruz guidopal@ensp.fiocruz.br

\section{Jairnilson Silva Paim}

Instituto de Saúde Coletiva/Universidade Federal da Bahia jairnil@ufba.br

\section{Margareth Crisóstomo Portela}

Departamento de Administração e Planejamento em Saúde Escola Nacional de Saúde Pública/Fundação Oswaldo Cruz mportela@ensp.fiocruz.br

\section{Marilene de Castilho Sá}

Departamento de Administração e Planejamento em Saúde Escola Nacional de Saúde Pública/Fundação Oswaldo Cruz marilene@ensp.fiocruz.br 


\section{Marilia Sá Carvalho}

Departamento de Epidemiologia e Métodos Quantitativos em Saúde Escola Nacional de Saúde Pública/Fundação Oswaldo Cruz marilia@procc.fiocruz.br

\section{Patricia T. R. Lucchese}

Departamento de Ciências Sociais/Escola Nacional de Saúde Pública Fundação Oswaldo Cruz

lucchese@ensp.fiocruz.br

\section{Regina Cele de A. Bodstein}

Departamento de Ciências Sociais/Escola Nacional de Saúde Pública Fundação Oswaldo Cruz

bodstein@ensp.fiocruz.br

\section{Sueli Gandolfi Dallari}

Departamento de Prática de Saúde Pública/Faculdade de Saúde Pública Universidade de São Paulo

dallari@originet.com.br

\section{Suely Rozenfeld (org)}

Departamento de Epidemiologia e Métodos Quantitativos em Saúde Escola Nacional de Saúde Pública/Fundação Oswaldo Cruz rozenfel@ensp.fiocruz.br

\section{Vera Lúcia Edais Pepe}

Departamento de Administração e Planejamento em Saúde Escola Nacional de Saúde Pública/Fundação Oswaldo Cruz verapepe@ensp.fiocruz.br 


\section{Prefácio}

\section{Apresentação}

\section{Marcos históricos e conceituais}

15 Constituição da Vigilância Sanitária no Brasil Ediná Alves Costa, Suely Rozenfeld

41 Conceitos e área de abrangência Ediná Alves Costa

49 SUS, modelos assistenciais e Vigilância da Saúde Carmem Fontes Teixeira, Jairnilson Silva Paim, Ana Luiza Vilasbôas

61 Organização e funções do Estado

63 Complexidade da ordem social contemporânea e redefiniçăo da responsabilidade pública Regina Cele de A. Bodstein

99 A Vigilância Sanitária, segundo as normas operacionais básicas do Ministério da Saúde Patricia T. R. Lucchese

113 Organização jurídica da administração pública em saúde Sueli Gandolfi Dallari

135 Epidemiologia

Guido Palmeira

195 Planejamento estratégico

Marilene de Castilho Sá, Vera Lúcia Edais Pepe

233 Informação: da produção à utilização Marilia Sá Carvalho

\section{Avaliação da qualidade}

259 Avaliação da qualidade em saúde Margareth Crisóstomo Portela

2710 Laboratório Oficial na avaliação analitica Ana Célia Pessoa da Silva 

Concebido como material didático para o Curso de Aperfeiçoamento à Distância em Vigilância Sanitária, o presente livro ultrapassou seu molde e ganhou vida própria: é mais do que um livro e mais do que um curso.

Como livro, por seu conteúdo atualizado e abordagem inovadora, é antes de tudo um guia qualificado para a ação em Vigilância Sanitária. Não uma cartilha de procedimentos normativos, ou um compêndio de erudição acadêmica, mas uma fonte dinâmica de referências conceituais e empíricas indispensáveis à competência profissional na área. Entendendo a saúde como produção social complexa, não mera contingência biológica, define e constrói um tripé de competências para qualificar o agir em Vigilância Sanitária: cónhecimento técnico, responsabilidade pública e compromisso ético. Alcança e interessa, assim, não só a profissionais de saúde, sejam gestores ou operadores do setor, como também a estudantes, professores e cidadãos em geral, na busca de uma educação para a cidadania.

Como componente do kit didático do Curso de Aperfeiçoamento à Distância em Vigilância Sanitária, acompanhado de outros materiais e do apoio docente à distância, fornece a base teórico-metodológica aos alunos que farão seu aprendizado, não através da leitura sequencial de seus capítulos, mas através do estudo orientado de um conjunto de situações-problema e study cases, apresentados em programas interativos integrantes de CD-ROMs de uso individual. Compondo um projeto educacional comprometido com as necessidades concretas dos serviços de saúde, o Curso propōe um trajeto pedagógico que, partindo da experiência prévia dos alunos, orienta-se para a construção de um novo conhecimento, habilitado a impactar positivamente as práticas de Vigilância Sanitária. 
Coordenada pela professora Suely Rozenfeld, a equipe de autores não poderia ser mais qualificada para a tarefa, dado o seu perfil peculiar que combina experiência acadêmica com experiência profissional em serviços.

$\mathrm{Na}$ verdade, o presente livro-curso condensa, de forma especial, o propósito maior do Programa de Educação à Distância da ENSP/FIOCRUZ, nos marcos e na perspectiva da Escola de Governo em Saúde: ampliar a capacidade e a qualidade de gestão da política pública de saúde no Brasil.

Pelo seu conteúdo programático e por sua abordagem pedagógica, tem condições de contribuir efetivamente para a consolidação do Sistema Único de Saúde, tanto na sua dimensão de reforma da saúde, quanto na de reforma do Estado.

Como reforma da saúde, na medida em que o objeto do livro-curso - a Vigilância Sanitária - é campo estratégico para a afirmação prática de um modelo de atenção que, para além das demandas clínico-assistenciais, seja capaz de se pautar pelas exigências intersetoriais de uma política de saúde voltada para a qualidade de vida.

Como reforma do Estado, na medida em que o curso estará capacitando, de forma descentralizada, flexível e adequada às realidades locais, um estoque de "gestores públicos de saúde" capazes de dotar as repartições estatais de qualificação técnica e responsabilidade social para a ação pública em saúde.

Antonio Ivo de Carvalho

Coordenador do EAD/ENSP 
Nos últimos dois anos, ocorrem mudanças significativas na Vigilância Sanitária. Entre elas, destaca-se a possibilidade de captação de recursos financeiros, por parte dos municípios, para as ações de Vigilância, como decorrência do processo de descentralização do SUS. Além disso, cresce o apoio à formação de recursos humanos, a cidadania está mais atenta aos seus direitos e são feitas alterações organizacionais importantes.

Ao mesmo tempo, acentua-se o desmonte das estruturas de sustentação do mundo do trabalho, patrocinada pelo modelo econômico neoliberal. Gera-se desemprego e terceirização da economia. Para compensar, cresce a procura por qualificação profissional, se valoriza a educação como forma de acesso ao mercado de trabalho, e surgem novas modalidades de ensino e aprendizado.

Esse panorama encontra a Escola Nacional de Saúde Pública/ENSP, da Fiocruz, realizando, na última década, um projeto de formação de profissionais em Vigilância Sanitária. Tal projeto, desenvolvido, ao mesmo tempo, em instituições de saúde pública de outros Estados, se assenta na busca do fio condutor a unir as diferentes dimensões da Vigilância e de nova conceituação para a área. Assim, são oferecidos cursos de especialização em Vigilância e módulos de Vigilância em outros cursos.

No início de 1998, a ENSP, dentro do Programa de Educação à Distância, e na perspectiva de ampliar o seu potencial para formar quadros, se propôs oferecer um curso de Vigilância Sanitária à distância, cujo primeiro produto é objeto desta apresentação.

Esse livro resulta do esforço para colocar à disposição dos profissionais de saúde um conjunto de textos, articulados entre si, um corpo de conhecimentos teóricos e metodológicos capazes de sustentar a prática em Vigilância Sanitária. O ponto de partida desse esforço é a com- 
preensão da Vigilância como parte da saúde pública. Tal compreensão não é automática. Afinal, em tempo pretérito, a Vigilância pertenceu aos órgãos públicos encarregados dos negócios da indústria e do comércio!

Dada sua natureza de instância de mediação entre a produção de bens e serviços variados e a saúde da população, a complexidade da Vigilância impôs um enfoque multidisciplinar. Esse enfoque aparece ao se observar os campos de origem de cada um dos capítulos desta coletânea: a sociologia, que fornece o instrumental para a análise histórica e para a compreensão do papel do Estado, a epidemiologia, o planejamento, a legislação e a avaliação, que fornecem os conceitos, os procedimentos e as técnicas necessárias ao desempenho da função reguladora e normativa.

O resultado desta composição deverá proporcionar aquisição de conhecimentos, num processo de leitura agradável e estimulante.

A realização do livro teve o apoio financeiro da Coordenação de Fiscalização Sanitária, da Secretaria de Estado de Saúde, do Rio de Janeiro, e da Agência Nacional de Vigilância Sanitária, do Ministério da Saúde.

Devo agradecimentos sinceros aos autores dos textos, pelo muito que se envolveram no caráter inovador e de formulação coletiva, e toparam empreender a árdua viajem. São especialistas da ENSP e de outras instituições do País, com larga experiência de ensino e pesquisa, em Vigilância ou em campos específicos da saúde pública. Devo agradecimentos especiais a Luis Carlos Wanderley Lima, Maria de Lourdes Moura, Gisele Huf e Marcos Moreira; eles colaboraram decisivamente para o resultado final.

Suely Rozenfeld 


\section{Marcos históricos e conceituais}

\section{Conteúdo}

Vigilância Sanitária, Vigilância Epidemiológica e Vigilância em Saúde. Conceitos e campos de abrangência. Origens, determinações econômicas, sociais e históricas da área. O Estado na regulação e na garantia da qualidade em saúde.

A leitura deve permitir:

- Compreender os diferentes modelos de atuação da Vigilância Sanitária no Brasil, ao longo do tempo. Perceber as articulações entre a função reguladora do Estado, o mercado e o consumo de bens e serviços. Identificar as relações da Vigilância Sanitária com as demais políticas do setor saúde.

- Conhecer o significado dos termos controle e fiscalização; defesa e proteção; higiene; inocuidade; nocividade; qualidade; segurança; risco.

- Compreender a evolução histórica dos conceitos de Vigilância Sanitária, Vigilância Epidemiológica e Vigilância da Saúde.

- Identificar as ações - normatização, registro, inspeção, fiscalização e monitoramento - e os produtos, serviços, ambientes e processos de trabalho que são objeto da Vigilância Sanitária. 



\title{
Constituição da Vigilância Sanitária no Brasil
}

\author{
Ediná Alves Costa, Suely Rozenfeld
}

\section{Introdução}

A Vigilância Sanitária é a forma mais complexa de existência da Saúde Pública, pois suas ações, de natureza eminentemente preventiva, perpassam todas as práticas médico-sanitárias: promoção, proteção, recuperação e reabilitação da saúde. A Vigilância Sanitária atua sobre fatores de risco associados a produtos, insumos e serviços relacionados com a saúde, com o ambiente e o ambiente de trabalho, com a circulação internacional de transportes, cargas e pessoas. Os saberes e práticas da Vigilância Sanitária se situam num campo de convergência de várias disciplinas e áreas do conhecimento humano, tais como química, farmacologia, epidemiologia, engenharia civil, sociologia política, direito, economia política, administração pública, planejamento e gerência, biossegurança, bioética e outras. De todas essas disciplinas e áreas a Vigilância Sanitária se alimenta e se beneficia, no sentido de ganhar mais eficácia.

No Brasil, até 1988, o Ministério da Saúde definia a Vigilância Sanitária como "um conjunto de medidas que visam elaborar, controlar a aplicação e fiscalizar o cumprimento de normas e padrões de interesse sanitário relativo a portos, aeroportos e fronteiras, medicamentos, cosméticos, alimentos, saneantes e bens, respeitada a legislação pertinente, bem como o exercício profissional relacionado com a saúde." A Lei n 8.080, de 19 de setembro de 1990, chamada Lei Orgânica da Saúde, organiza o Sistema Único de Saúde e definiu a Vigilância Sanitária como "um conjunto de ações capaz de eliminar, diminuir, ou prevenir riscos à saúde e de intervir nos problemas sanitários decorrentes do meio ambiente, da produção e circulação de bens e da prestação de ser- campo de convergência de disciplinas 


\section{definição de} vigilância sanitária

ideologia do consumo

interesses difusos viços de interesse da saúde." Ao contrário da anterior - de caráter burocrático, normativo - esta definição introduz o conceito de risco e confere um caráter mais completo ao conjunto das ações, situando-as na esfera da produção. E assim, harmoniza-se melhor com o papel do Estado hodierno, em sua função reguladora da produção econômica, do mercado e do consumo, em benefício da saúde humana.

A evolução de uma definição a outra se deu no processo social no seio do qual se formou o movimento pela democratização da saúde, cujas proposições, sistematizadas na 8a Conferência Nacional de Saúde, de 1986, foram, em grande parte, acolhidas na Constituição Federal de 1988. Segundo esta Constituição, a saúde é um direito de todos e um dever do Estado. E nesse novo conceito se incluem as ações de Vigilância Sanitária.

Uma das principais características das sociedades modernas é o consumo sempre crescente de mercadorias, bens e serviços, inclusive de produtos de interesse sanitário, de tecnologias médicas e de serviços de saúde. Esse consumo está distante das reais necessidades das pessoas, pois não se baseia em escolhas livres e conscientes, mas num sistema de necessidades determinado por toda a organização social. Isso ocorre porque o modo de produção capitalista - cujo móvel é o lucro cria o imperativo de produzir e de vender, em escala crescente, não apenas produtos que aprimoram o bem-estar dos homens, mas também velhos produtos "maquiados", ou novos produtos, elaborados para atender fictícias necessidades, ou necessidades artificialmente criadas. Um complexo sistema de propaganda alimenta as necessidades, num processo coletivo que aprisiona as vontades individuais e estimula incessantemente o consumo. A ideologia do consumo transforma as coisas e as pessoas em objeto de compra, mascara as diferenças entre os vários segmentos da sociedade e simula a igualdade entre todos.

Na dinâmica contraditória e complexa desses processos são gerados muitos riscos e danos à saúde do indivíduo e da coletividade, assim como ao meio ambiente e à economia do consumidor. As açōes de Vigilância Sanitária se inserem no âmbito das relações sociais de produção e consumo, onde se origina a maior parte dos problemas de saúde sobre os quais é preciso interferir. Tais problemas podem advir de falhas, ou defeitos, em algum ponto da cadeia de produção, ou de ilicitudes intencionais de fabricantes, comerciantes ou prestadores de serviços. Assim, existe a necessidade de regulação das relações de produção e consumo, se reconhece a vulnerabilidade do consumidor e se criam instrumentos para proteger a saúde de toda a coletividade.

Nos dias atuais, amplia-se a abrangência da Vigilância Sanitária, com o alargamento do campo dos interesses difusos, cujo conceito gira 
em torno da noção de qualidade de vida. Os interesses difusos dizem respeito à sociedade de massa, na qual os grupos tomam o lugar dos indivíduos. E se referem a áreas e temas de largo espectro social, tais como, a ecologia, a qualidade de vida, a tutela de consumidores, a defesa dos direitos humanos, das etnias e outros. Esses temas ultrapassam os interesses dos indivíduos e alcançam toda a coletividade.

O modelo criado para regular as relações produção-consumo desenvolvido na Vigilância Sanitária, no Brasil, ao longo do tempo, se tem calcado no poder de polícia, com pouca visibilidade para o público e até mesmo para os profissionais de saúde. Sua ação mais visível é a fiscalizadora, mesmo quando insuficientemente exercida. $\mathrm{O}$ poder de polícia é inerente ao Estado, é um poder-dever que se concretiza na elaboração de normas jurídicas e técnicas e na fiscalização de seu cumprimento, assim limitando as liberdades individuais, e as condicionando aos interesses coletivos assegurados pelo Poder Judiciário.

A redução das práticas da Vigilância ao próprio poder de polícia e à fiscalização, tem produzido sérias distorções. A fiscalização é uma função essencial e intransferível do Estado, mas reduzir a ação da Vigilância à mesma é simplificar o longo processo histórico de construção do seu objeto e limitar seu alcance na transformação das condições de saúde.

A instrumentalização legal é condição para o exercício de diversas práticas da Vigilância Sanitária, devido à natureza jurídico-política de sua intervenção, disciplinadora da vida em sociedade, e aos aspectos técnico-sanitários. A lei é uma expressão do sistema jurídico definido na Constituição, a lei magna do país; a lei contém a essência dos direitos e deveres referentes a seu objeto de normatização, e expressa a vontade da organização social, através do Poder Legislativo. As normas técnicas, congregando direito e norma, compõem os códigos que visam assegurar os princípios de saúde pública, acompanhando a evolução da ciência e da tecnologia.

Para que a Vigilância Sanitária possa cumprir suas finalidades, num universo abrangente, dinâmico e complexo, suas práticas devem articular-se, integrar-se, estrategicamente, ao conjunto das práticas sanitárias, com o uso concomitante de vários instrumentos, com participação e controle social. Como decorrência do caráter interdisciplinar, as ações da Vigilância incorporam várias acepções da noção de risco, tais como: perigo virtual ou ameaça de agravos relacionados com determinados elementos que o homem aprendeu a identificar na experiência cotidiana; e, na acepção epidemiológica, no sentido de probabilidade, estatisticamente verificável, de ocorrer um evento adverso à saúde, na presença de determinado fator. Antes mesmo do surgimento da medici- poder de policia

instrumentalização legal 
comunicação e educação em saúde

sistemas de informação na científica e do desenvolvimento da epidemiologia, e, consequentemente da elaboração do conceito de risco, já haviam sido estabelecidas normas de proteção à saúde da coletividade.

Existem riscos à saúde em incontáveis áreas da produção. Há ris$\cos$ no uso de medicamentos, hemoderivados, vacinas, alimentos, saneantes, cosméticos, agrotóxicos etc. As ações de controle sanitário nos portos, aeroportos e fronteiras visam proteger não apenas a população dos riscos inerentes à circulação de mercadorias e pessoas, como também proteger a agricultura e os rebanhos contra a introdução de doenças exóticas, que podem acarretar enormes prejuízos econômicos. $\mathrm{Na}$ prestação de serviços - direta ou indiretamente relacionados com a saúde - também há riscos, multiplicados pelo uso concomitante de várias tecnologias. Devemos igualmente lembrar os potenciais efeitos nocivos dos resíduos manejados inadequadamente. O consumo de recursos naturais e outras intervenções sobre o meio ambiente podem trazer riscos à saúde humana e à saúde animal. São inumeráveis os riscos à saúde em ambientes de trabalho, devidos a substâncias químicas, máquinas e equipamentos, poeiras, ruídos, temperaturas extremas entre outros. Muitas vezes a deposição dos resíduos industriais constitui sérios riscos à saúde humana e ambiental, e ultrapassa as fronteiras de um país. Os resíduos radioativos, por exemplo, constituem sério problema de saúde coletiva, em escala planetária. Esta situação é ainda mais grave em países como o nosso, onde os problemas ligados ao saneamento básico ainda não foram resolvidos.

Uma vez identificados os riscos, é preciso empreender ações de controle. Para tanto, devem ser empregados múltiplos instrumentos, além da legislação e da fiscalização: a comunicação e a educação sanitá. ria, os sistemas de informação, o monitoramento da qualidade de produtos e serviços, a vigilância epidemiológica de eventos adversos, relacionados às condições do trabalho e do ambiente e ao consumo de tecnologias médicas, de água e de alimentos.

A comunicação e a educação em saúde são de fundamental importância para as ações de Vigilância, tanto pela democratização do conhecimento, quanto pelo caráter pedagógico dos atos administrativos. Quando se baseiam no diálogo, as práticas desse campo contribuem para a construção da consciência sanitária, dando aos cidadãos meios de defesa contra inumeráveis riscos, e contra práticas nocivas do sistema produtivo, na busca incessante de lucros.

Os sistemas de informação alimentam as práticas de Vigilância, fornecendo subsídios para a avaliação do impacto das ações e para manter a Vigilância atualizada com os avanços do conhecimento científico e tecnológico. 
O monitoramento se incorporou recentemente ao campo da Saúde Pública. Essa prática nasceu na área de cuidados intensivos de saúde, como coleta sistemática de informações, para alertar quanto à necessidade de intervenção. O termo significa acompanhar e avaliar, controlar mediante acompanhamento, controlar e ajustar ou olhar atentamente, observar ou controlar com propósito especial. ${ }^{1}$

A Vigilância Epidemiológica criou um modelo de acompanhamento de doenças infecciosas, posteriormente ampliado a um conjunto de eventos que abrange desde as malformações congênitas até as doenças crônico-degenerativas; este instrumento vem, pouco a pouco, sendo empregado pelos órgãos de Vigilância Sanitária das administrações públicas estaduais e federais.

É importante ressaltar o papel do laboratório na estrutura da Vigilância Sanitária. O laboratório deve ser moderno e estar equipado para dar respostas ágeis na avaliação da qualidade de produtos e das repercussões de riscos e de agravos sobre a saúde das pessoas.

Conhecer o desenvolvimento histórico da Vigilância Sanitária no Brasil, ainda que de maneira resumida, assim como a evolução dos conceitos que sustentam a mesma, contribui para a escolha da melhor forma de o profissional atuar em cada situação.

\section{Origens históricas}

A busca da saúde acompanha a história das civilizações. Ações de controle sobre o exercício da medicina, o meio ambiente, os medicamentos e os alimentos existiram desde longínquas eras. Povos antigos, como os babilônios e os hindús, estabeleceram preceitos morais e religiosos - fixados nos códigos de Hamurabi e de Ur-Namu, respectivamente - e regras sobre a conduta dos profissionais que tratavam das doenças. A saúde era considerada essencial à dignidade humana. Achados arqueológicos demonstram que no século XVI a.C. o homem já possuía habilidade para preparar drogas, e lhes delimitar prazos de validade. Os alimentos também faziam parte das preocupações de povos antigos, e até mesmo os perfumes, que poderiam ser objeto de práticas desonestas por parte dos comerciantes. Na Índia, em 300 a.C., uma lei proibiu a adulteração de alimentos, medicamentos e perfumes. Desde a Antigüidade Clássica até a Idade Média se desenvolveram ações de saneamento do meio

\footnotetext{
${ }^{1}$ WALDMAN, E. Vigilância epidemiológica como prática de Saúde Pública. São Paulo, 1991 [Tese de Doutoramento - Faculdade de Saúde Pública da USP, Departamento de Epidemiologia].
}

\section{Vigilância \\ Epidemiológica}

monitoramento

\section{laboratório}


1348, vigilância

dos portos

poder público

processo de acumulação de capital ambiente (controle da água e do esgoto, limpeza das ruas e dos mercados); normatização da prática profissional dos médicos, dos cirurgiões e dos farmacêuticos; determinação de observância de cuidados para com os medicamentos, as boticas, os alimentos. A partir das medidas estabelecidas em Veneza, em 1348, teve início a vigilância dos portos para impedir a entrada de epidemias nas cidades. Veneza era o porto mais importante da Europa para a chegada das mercadorias vindas do Oriente. Visando barrar a entrada da peste nessa cidade, se estabeleceu a inspeção das embarcações e das suas cargas, especialmente quando infectadas ou suspeitas, colocando-se os passageiros sob regime de quarentena, com exposição ao ar e à luz solar. ${ }^{2}$

Desde a Antigüidade, a solução desses problemas cabia à administração das cidades, sinal de ser a proteção da saúde da coletividade uma função do poder público. Leis e normas disciplinavam a vida em sociedade, a despeito do desconhecimento do modo como os agentes causadores das doenças se relacionavam com as mesmas.

A partir de meados do século XVI, uma transformação da ordem econômica, ensejou a ascensão de uma nova classe social - a burguesia - e a conformação de uma nova noção de riqueza - a mercantil, baseada no comércio de mercadorias e no dinheiro. Em alguns países europeus se intensificaram as trocas comerciais, inclusive com as colônias e com os países do Oriente. Houve um processo de acumulação de capital comercial, fundamental para a formação do capital industrial, passo seguinte do desenvolvimento econômico.

Nesse período se formou o Estado moderno, e surgiram os conceitos de Estado, Governo, Nação e Povo. Estava iniciada a história contemporânea. O absolutismo dominava a filosofia política, e constituiu o primeiro sistema estatal internacional moderno. Monarcas introduziram o exército permanente, o sistema fiscal nacional, a codificação do direito, os princípios do mercado unificado, e as regulamentações econômicas se tornaram mais exigentes. Na vigência desse regime, o trabalho passou a ser considerado a principal fonte de riqueza. O cerne da política social era a raison d'État. Controlando os fluxos monetários e os respectivos fluxos de mercadoria entre as nações, e as atividades produtivas da população, o Estado poderia estabelecer os fluxos comerciais e assegurar a entrada do maior volume possível de moedas. Com as moedas, o Estado pagava o exército, para garantir e defender os territórios, e mantinha outras estruturas. aue asseguravam a forca real de um Estado frente aos demais.

\footnotetext{
2 Ver o importante trabalho de GEORGE ROSEN, Uma história da Saúde Pública, editado em 1994 pela Unesp/Hucitec/ABRASCO (2a edição, revista, 1998).
} 
As bases para a intervenção na saúde do povo se estabeleceram segundo o pensamento de que para aumentar o poder e a riqueza nacionais era necessário uma população grande, bem cuidada e controlada. Nesse contexto, surgiram, no século XVIII, as estatísticas populacionais e o conceito de polícia médica. O termo polícia, derivado da palavra grega politeia, - constituição ou administração de um Estado - já era usado por escritores alemães no século XVII, como ramo da administração da Saúde Pública.

Com a publicação da obra de Peter Frank ${ }^{3}$ a noção de polícia médica disseminou-se em países europeus, servindo de base para muitas propostas de intervenção sobre os problemas de saúde e saneamento do meio, sendo especialmente útil como guia para os funcionários públicos encarregados de regular a atividade humana. Nessa obra, os problemas eram organizados num sistema de higiene pública e privada, e seria responsabilidade do Estado conformar e aplicar um código de leis de promoção e manutenção da saúde. Assim, regulamentavam-se as profissões, o partejo, a pureza da água e dos alimentos, a higiene do meio, a responsabilidade pelos acidentes etc.

Contrapondo-se ao absolutismo, o liberalismo cresceu, no século XVIII, adquirindo consistência como doutrina. Com as revoluções burguesas, deu-se a apropriação do poder político pela nova classe social, criando-se, e consolidando-se, o Estado liberal. Com a nova configuração político-econômica, no início do século XIX, o conceito de polícia médica, como superestrutura ideológica sustentada pelo absolutismo e pelo mercantilismo, estava ultrapassado. Restou, contudo, a noção de sistematização das atividades administrativas e de fiscalização do cumprimento das normas sanitárias. Outro conceito fundamental na constituição da Vigilância Sanitária surgiu no final do século XVIII, na França: a noção de salubridade. Este conceito dizia respeito ao estado das coisas, do meio e de seus elementos constitutivos que, em sendo salubres, favorecem a saúde. Dessa noção, se originou, no século XIX, a de higiene pública, como controle político-científico do meio. ${ }^{4}$

A intensificação da industrialização ampliou o campo da regulamentação, e, consequentemente, a produção de normas. Impulsionaram essa produção a natureza do Estado moderno, o desenvolvimento da ciência e da tecnologia, as forças produtivas e a evolução da luta de classes. A criação dos institutos de pesquisa e dos laboratórios de saúde pública, nas últimas décadas do século passado, deram novas bases para a ampliação polícia médica

Peter Frank

cumprimento

das normas sanitárias

salubridade

industrialização

\footnotetext{
${ }^{3}$ Ver ROSEN, nota anterior.

${ }^{4}$ Ver também FOUCAULT, M. Microfísica do Poder. $1^{14}$ ed. Rio de Janeiro, Graal, 1993, p. 79-98.
} 
adulteração e falsificação de produtos talidomida das práticas sanitárias em geral e, em especial, de práticas fundamentais no campo da Vigilância Sanitária. Nos Estados Unidos, por exemplo, a produção industrial de alimentos e de medicamentos cresceu muito no final do século XIX, e se fez acompanhar de muitas denúncias de adulteração e de falsificação de produtos e de utilização abusiva de conservantes. Análises laboratoriais, divulgadas para o público, fomentaram a mobilização popular na luta em defesa de medidas de proteção à saúde, e resultaram em ampla legislação de controle, no início do século XX. Desde então, eventos negativos para a saúde da população têm servido de elemento propulsor para as reformulações de normas reguladoras da produção, do comércio e do consumo de produtos relacionados com a saúde e, também, de serviços e de intervenções no ambiente, em muitos países.

Na década de 1960, o episódio da talidomida - que resultou no nascimento de milhares de bebês com deformidades dos membros - constituiu-se num marco da história da regulamentação sanitária em todo o mundo. Após esse trágico acontecimento, criaram-se órgãos nacionais de controle e se publicou farta legislação, na maioria dos países, com vistas a se garantir a segurança dos produtos. Inaugurou-se uma era, na qual se atribuiu aos fabricantes responsabilidade pela qualidade dos produtos oferecidos ao mercado e onde o monitoramento dos efeitos adversos, sobretudo de medicamentos, passou a ser comum em países desenvolvidos.

A constituição da Organização Mundial da Saúde, após a Segunda Guerra, se acompanhou da proclamação da saúde como um dos direitos humanos fundamentais. E tem estimulado, entre outras matérias, o aperfeiçoamento da legislação sanitária e de práticas do campo da Vigilância, como a Farmacovigilância e a Vigilância Epidemiológica das toxiinfecções alimentares; essas práticas permitem acompanhar a situação de saúde, tendo por referência a qualidade de produtos sob controle da Vigilância. E a legislação sanitária internacional facilita as trocas comerciais entre os países.

\section{A constituição da Vigilância Sanitária no Brasil}

Da monarquia até o fim da República Velha (1930)

Com relação à história do controle sanitário no Brasil-Colônia, o livro de Machado e seus colaboradores ${ }^{5}$ traz muitas informações sobre

\footnotetext{
5 MACHADO, R. et al. Danação da Norma: a Medicina Social e a Constituição da Psiquiatria no Brasil. Rio de Janeiro, Graal, 1978.
} 
o pensamento dominante na organização sanitária, expresso nos regimentos editados pelos soberanos. O controle baseava-se no modelo existente em Portugal, com ênfase na necessidade de se legitimar os ofícios de físico, cirurgião e boticário e de se arrecadar emolumentos. Às Câmaras Municipais cabiam as medidas de higiene pública: limpeza das cidades, controle da água e do esgoto, comércio de alimentos, abate de animais e controle das regiões portuárias. Embora de eficácia reduzida, desde o século XVI houve ações de fiscalização e de punição no Brasil.

A chegada da família real portuguesa, em 1808, desencadeou profundas mudanças, relacionadas com a nova inserção do Brasil nas transformações da ordem capitalista mundial e com as necessidades de aumentar a produção, defender a terra e cuidar da saúde da população. Foram criadas várias instituições, entre as quais as Escolas de Cirurgias. Como o Brasil passou a fazer parte das rotas comerciais inglesas, e de outras "nações amigas", intensificou-se o fluxo de embarcações e a circulação de passageiros e de mercadorias. Aumentou assim, a necessidade de controle sanitário, para se evitarem as doenças epidêmicas e para se criarem condições de aceitação dos produtos brasileiros no mercado internacional. ${ }^{6}$ As atividades sanitárias mantinham seu caráter fiscalizador, julgador e punitivo, e as autoridades detinham o poder de tributar, e de arrecadar as taxas sobre os respectivos serviços.

Em 1810, entrou em vigência o Regimento da Provedoria, que dava forma a um novo tipo de prática, baseada no modelo da polícia médica, difundido no continente europeu, e expressava uma nova relação entre a medicina e o Estado. Através desse Regimento, a sociedade passava a ser objeto de regulamentação médica e a saúde passava a ser um problema social. Estabeleceram-se normas para o controle sanitário dos portos, instituíram-se a quarentena e o Lazareto, para isolamento de doentes de moléstias contagiosas; o controle de alimentos; a inspeção de matadouros, açougues públicos, boticas, drogas e medicamentos; a fiscalização e os exames para a concessão de licença para o exercício da medicina e da farmácia. Mas essas ações tinham pouco alcance nas áreas do território brasileiro situadas para além da sede do governo. ${ }^{7}$

Com o reaparelhamento geral do Estado, após a Independência, decretou-se na capital a municipalização dos serviços sanitários. Em conseqüência, as Câmaras Municipais passaram a reorganizar-se e a estabelecer seus Regimentos. A Sociedade de Medicina e Cirurgia. cria- século XVI, ações

de fiscalizaçāo

produtos brasileiros no

mercado internacional

1810, Regimento

da Provedoria

6 COSTA, N.R. Lutas urbanas e controle sanitário: origens das politicas de saúde no Brasil. Petrópolis, Vozes/ABRASCO, 1985.

${ }^{7}$ MACHADO, R. et al, 1978, ibidem. 
1832, Código

de Posturas da em 1829, constituiu-se em importante aliada do Estado. Inspirada na medicina francesa, a entidade centralizava a explicação das doenças no meio ambiente, criando, assim, uma relação entre a ordem moral e a saúde, e colaborava na elaboração de normas sanitárias e na proposição de medidas para o combate de doenças. E cobrava do Estado ação enérgica contra todas as demais práticas de cura, consideradas charlatanismo, mesmo se as práticas da medicina oficial só abarcassem uma pequena faixa da população. Com o apoio dessa Sociedade, a Câmara Municipal do Rio de Janeiro elaborou um Código de Posturas, e o promulgou em 1832. O Código estabelecia normas para cemitérios e enterros, para doenças contagiosas, para pântanos e águas infectadas, matadouros, currais, açougues e gêneros alimentícios, para o exercício da medicina e da farmácia, para o controle de medicamentos, hospitais, casas de saúde e fábricas. O Código introduziu, ainda, a prática da licença no controle das fábricas. ${ }^{8}$

No transcorrer do tempo, a organização sanitária passou por reformas, de maior ou menor envergadura, e pela ampliação de suas funções. Em 1851, por exemplo, numa medida inédita, uma portaria do Ministro de Negócios do Império proibiu a criação de novas casas de saúde sem consulta prévia à Junta de Higiene Pública. E se caracterizou pela atribuição de determinadas funções ao plano federal - a exem. plo do controle sanitário dos portos e fronteiras e do exercício da medicina e farmácia - e, em menor parte, a Estados e Municípios. Porém, em decorrência da precariedade desses, em 1849, numa situação epidêmica, se revogou a municipalização, recriando-se órgãos centralizados, numa tentativa de melhorar os Serviços Sanitários do Império. A nação brasileira que veio se formando, desde a Colônia, se caracterizou por imensas desigualdades sociais, pela manutenção de um quadro sanitário negativo para a maioria da população e pela edição de muitas leis e normas, sem observância das mesmas. E por sistemas de saúde que vão se estruturando essencialmente voltados para a doença, com imenso descaso pelas medidas de cunho preventivo e coletivo e de promoção da saúde.

Ao final do período monárquico, o país registrava cerca de seiscentos estabelecimentos industriais. Em termos de capital investido, a indústria de alimentos ocupava o segundo lugar e a de produtos químicos e análogos, o terceiro. ${ }^{9}$ Finda a escravidão, intensificaram-se o fluxo de imigrantes europeus. vara atender às necessidades de forca de traba-

\footnotetext{
8 Idem, ibidem

9 PRADO JÚNIOR, C. História econômica do Brasil. 2 a edição, São Paulo, Brasiliense, 1981.
} 
lho na economia em expansão, e o fluxo migratório interno, em direção às áreas produtivas mais dinâmicas. Houve profundas mudanças geoeconômicas e demográficas, incremento do processo de urbanização e empobrecimento econômico do Nordeste. Expandiram-se a produção cafeeira e o comércio internacional, deram-se melhorias nas cidades portuárias, para garantia de condições sanitárias capazes de assegurar a exportação de mercadorias e a vinda de imigrantes para trabalhar na agricultura.

A instauração da República marcou o início da organização das administrações sanitárias estaduais e a constituição de órgãos de Vigilância Sanitária nas Unidades da Federação. Atribuiu-se à União a responsabilidade pelos estudos das doenças, pelas medidas profiláticas, pelas estatísticas demográfica e sanitária, pela fiscalização do exercício profissional da medicina e da farmácia, pela análise de substâncias importadas e pelo controle das doenças na Capital Federal, nos portos e nas fronteiras. A ação de combate às doenças infectocontagiosas passou a fundamentar-se na pesquisa bacteriológica - beneficiada pela criação dos Institutos de Pesquisa - e nas intervenções da polícia sanitária. Intensificaram-se a produção de normas e o esquadrinhamento do espaço urbano, e o saber médico ganhou mais valor.

Mas a persistência de graves problemas sanitários, principalmente representados pelas doenças epidêmicas, transformava o país em objeto de pressões internacionais. E constituía ameaça às classes dominantes e ao processo de acumulação de capital, pois comprometia o comércio portuário, num país grande exportador de gêneros alimentícios e de produtos extrativistas, além de importante mercado consumidor. A intervenção sobre o Rio de Janeiro, no período de Oswaldo Cruz, e o célebre episódio da revolta de vacina, ilustram o primeiro período da República, e suas contradições, em meio a posições divergentes quanto às competências da União e dos Estados para legislar sobre as questões sanitárias: ${ }^{10}$ a Constituição da República, calcada no ideal liberal, seguiu a idéia de Unidades Federadas, como no modelo norte-americano, e nenhuma referência fez à saúde.

Na época de Oswaldo Cruz, a implantação de novo Regulamento dos Serviços Sanitários da União, aprovado pelo Decreto n² 5.156 de 1904, previu, pela primeira vez, a elaboração de um Código Sanitário pela União e a instituição, no Distrito Federal, do Juízo dos Feitos de Saúde Pública. A esse órgão incumbiria o iulgamento de causas de inte- administrações

sanitárias estaduais

Decreto no 5.156/04, Regulamento dos Serviços Sanitários da União

10 COSTA, N.R., 1985, ibidem 
resse da saúde pública, tais como, crimes e contravenções de higiene e salubridade públicas e a cobrança de multas e taxas sanitárias. Em razão do federalismo, a partir de 1889 Estados passaram a dispor de Código Sanitário próprio, antes mesmo da elaboração do Código Sanitário Federal, em 1923.

Nas duas primeiras décadas desse século, as ações da Vigilância Sanitária parecem adquirir certa consistência em alguns Estados, como o de São Paulo, com a implantação de ações de controle de medicamentos, estabelecimentos comerciais e alimentos, e a instalação de serviços de controle sanitário de carnes e leite, e de ações destinadas a fixar condições para a mão-de-obra estrangeira e viabilizar o processo de acumulação.

Nesse período, expandiu-se a atividade industrial e comercial, cresceu o movimento operário e organizaram-se os empresários. A Primeira Guerra impulsionou a indústria brasileira, estimulada pela exportação e pelo declínio das importações de mercadorias dos tradicionais países fornecedores, então envolvidos no conflito. O Censo de 1920 revelou a existência de 13.336 estabelecimentos industriais; a indústria de alimentos ocupava o primeiro lugar com $40,2 \%$ da produção, em conseqüência do aparecimento da indústria de congelamento de carnes destinadas ao mercado europeu. ${ }^{11}$ Além das subsidiárias de empresas estrangeiras do setor de alimentos, instalaram-se no País subsidiárias de outros ramos industriais, tais como as de produtos químico-farmacêuticos.

Mas, se as exportaçōes de alimentos aumentavam, graças a preços atraentes, as necessidades internas não eram atendidas, e a fome agravou o quadro epidêmico da gripe espanhola de 1918, um grave momento no qual a máquina estatal perde o controle. Assim, entre as reivindicações dos trabalhadores, nas greves de 1917, em São Paulo, estava a de obter preços mais baixos na compra de alimentos e a de controlar a falsificação dos mesmos.

$\mathrm{Na}$ década de vinte o país experimentou importantes transformações econômicas e políticas. A economia cafeeira atingiu seu auge, acelerou-se o processo de urbanização e de desenvolvimento industrial; as doenças de massa já haviam adquirido importância e a saúde pública crescia como questão social. Um conjunto de fenômenos determinou mudanças na forma de intervenção do Estado na saúde, intervenção que passa a se desenvolver em dois ramos. Ou seja, um modelo de assistência curativa-individual, dirigida à força de trabalho indispensável ao processo de acumulacão: e um modelo sanitário. camnanhis-

11 PRADO JUNIOR, C., 1981, ibidem 
ta, ${ }^{12}$ com um braço encarregado do controle de novos objetos, de importância crescente no processo industrial.

Com a Reforma Carlos Chagas, criou-se, através do Decreto-Lei n 3.987, de 1920, o Departamento Nacional de Saúde Pública (DNSP) que substituiu a Diretoria Geral de Saúde Pública, esta última criada em 1897. O DNSP estendeu a sua ação ao saneamento urbano e, formalmente, ao rural; aos serviços de higiene infantil; à higiene industrial e profissional; à supervisão dos hospitais públicos federais, e à fiscalização dos demais; à propaganda sanitária e ao combate às endemias e epidemias rurais. Mas em virtudes das limitações do país, essas ações tinham pouco alcance.

Em 31 de dezembro de 1923 se editou o Decreto n 16.300, com 1.679 artigos. Através desse Decreto que vigorou, por muito tempo, como Regulamento Sanitário Federal, pretendeu-se incluir praticamente a totalidade da vida social na ordem sanitária, e se fixaram disposições normativas minuciosas, muitas vezes inaplicáveis. O Decreto estabeleceu as competências do DNSP e dos órgãos afins e normatizou sobre: controle do exercício profissional; licenciamento prévio de farmácias, drogarias, laboratórios, ervanários e fábricas de medicamentos; licenciamento ou fiscalização de produtos farmacêuticos, soros, vacinas e produtos biológicos, desinfetantes, produtos de higiene e toucador, águas minerais naturais, com propriedades farmacêuticas; inspeção sanitária dos empregados domésticos, das amas-de-leite e de estabelecimentos comerciais; fiscalização de estabelecimentos destinados à infância, maternidades, hospitais, consultórios, escolas, creches e outros; fiscalização de mananciais, e análise das águas de abastecimento; domicílios, lugares e logradouros públicos, fábricas, oficinas, estabelecimentos comerciais e industriais, mercados, hotéis e restaurantes; fiscalização de gêneros alimentícios, inclusive de corantes e edulcorantes; defesa sanitária marítima e fluvial, e inspeção médica de imigrantes. Em relação ao controle sanitário de produtos se estabeleceram multas e penas de prisão, inafiançáveis, para os falsificadores de alimentos e outros produtos sob controle do DNSP, como medicamentos e produtos biológicos. O Regulamento incorporou a expressão Vigilância Sanitária, empregada indistintamente para o controle sanitário de pessoas doentes, ou suspeitas de moléstias transmissíveis, e de estabelecimentos e locais.

Esse diploma legal, tão amplo e detalhado, conformou o arcabouço das práticas de controle sanitário doravante implementadas. E se lhe

12 BRAGA, J.C.S \& PAULA, S.G. Saúde e previdència: estudos de politica social. 2a ed. São Paulo, Hucitec, 1985.
Decreto-Lei n² 3.987/20, Departamento Nacional de Saúde Pública

Decreto no $16.300 / 23$ 
Decreto ne 3.171/41, Serviço Nacional de Fiscalização da Medicina (SNFM)

Comissāo de Revisão da Farmacopéia; Comissão de Biofarmácia

Decreto-Lei ne 19.606/31 e Decreto ne 20.377/31, exercício da farmácia foram acrescentando mudanças ao longo do desenvolvimento histórico da Saúde Pública e, em particular, da Vigilância Sanitária, em consonância com o processo econômico e social.

\section{De 1930 a 1945, o Estado Novo}

O ano de 1930 demarcou um novo momento na sociedade brasilei$\mathrm{ra}$, com o rompimento da estrutura de poder da Primeira República e a emergência de um Estado forte, autoritário, centralizador. Este Estado, no contexto de uma crise de hegemonia, agia com certa independência em relação às oligarquias regionais. A opção pela industrialização, como alternativa viável de crescimento econômico, foi favorecida pela crise internacional de 1929, quando ganhou evidência a fragilidade do modelo econômico agro-exportador. Destacaram-se, pelo enorme desenvolvimento, a indústria químico-farmacêutica e a de agrotóxicos, impulsionadas, sobretudo, pelos acontecimentos ligados à Segunda Guerra Mundial. ${ }^{13}$

Houve intensa produção normativa e legal no período - com a promulgação, inclusive, das Constituições de 1934 e de 1937 - e as estruturas de saúde pública passaram por várias reformas, com criação e/ou especialização de órgãos e ampliação das suas funções. Merece destaque a criação, através do Decreto n 3.171/41, do Serviço Nacional de Fiscalização da Medicina (SNFM). O Serviço de Saúde dos Portos e o Serviço Federal de Águas e Esgotos, que já existiam à época da criação do SNFM, se mantém como órgãos separados. O Instituto Oswaldo Cruz, além de pesquisar e fabricar produtos farmacêuticos, passou a realizar exames laboratoriais, inclusive os relacionados ao controle sanitário de produtos químico-farmacêuticos. Juntamente com o SNFM foram criadas a Comissão de Revisão da Farmacopéia e a Comissão de Biofarmácia; esta última elaborou um grande número de normas, editadas em portarias, restringindo a produção e a comercialização de produtos, em benefício da saúde pública.

A edição de normas concentrou-se, principalmente, no campo dos medicamentos, dos soros e das vacinas. O Decreto-Lei ne $19.606 / 31$, e o Decreto ne 20.377/31, tratavam do exercício da farmácia e vigoraram por um longo período; muitas das suas normas vieram do Regulamento de 1923, mas adquiriram outro significado no contexto de industrialização e urbanização no Estado autoritário. Tal como se deu no Regulamento de 1923, muitos preceitos fixados nos decretos de 1931, embora

\footnotetext{
13 BODSTEIN, R. C. de A. (org). História e saúde pública: a politica de controle do câncer no Brasil. Rio de Janeiro, PC-ENSP, 1987.
} 
válidos, jamais foram cumpridos. A propaganda de produtos farmacêuticos e dos profissionais de saúde passou a ser regulamentada por instrumento específico, o Decreto-Lei n 4.113/42. Na área dos alimentos, surgiu o Decreto ne 19.604/31, reafirmando-se como crime, sujeito às penalidades previstas no Código Penal dar, vender e expor ao consumo público gêneros alimentícios fraudados. Um outro objeto do campo de abrangência da Vigilância Sanitária passou a contar com legislação específica - fixada no Decreto n 780/36 e no Decreto ne 891/38: o controle dos entorpecentes. O Decreto-Lei ne 7.841/45 aprovou o Código de Águas Minerais, sendo as suas ações atribuídas ao Ministério da Agricultura.

De 1945 a 1967

Junto a uma política econômica de incentivo à expansão do grande capital monopolista, ocorreram profundas mudanças de governo e de regime no País, secundadas por alterações na organização sanitária e no plano normativo. Promulgou-se uma nova Constituição. Após a queda de Getúlio Vargas, em 1945, seguiu-se um intenso movimento de entrada de capitais estrangeiros, inclusive o da indústria químico-farmacêutica e de alimentos. Houve remessa de lucros para o exterior, sustentada pelo discurso liberal e por um clima político de crescimento dos ideais redemocratizantes, acompanhado de políticas de cunho populista. ${ }^{14}$

$\mathrm{Na}$ área de medicamentos surgiu o Decreto ne 20.397/46, para regulação da indústria farmacêutica. Esse Decreto continha normas para controle de produtos - especialidades farmacêuticas, produtos oficinais e biológicos -, disposições especiais sobre psicotrópicos e entorpecentes, normas relativas a produtos químico-farmacêuticos, antissépticos, desinfetantes, de higiene e toucador, e regras para o funcionamento dos laboratórios fabricantes, tais como a licença prévia e a responsabilidade técnica. Apresentava, ainda, regras sobre propaganda, fraudes, análises fiscais, sanções para os infratores, colidência do nome de marca, cópia de fórmulas em produtos similares. Apesar da preocupação com a nocividade dos produtos, o conteúdo normativo deste Decreto estava intensamente voltado para legalização das atividades e para regulamentar a concorrência entre os fabricantes.

$\mathrm{Na}$ área de alimentos ocorreram grandes mudanças. A Lei ne 1.283/ 50 tornou obrigatória a prévia fiscalização de todos os produtos de origem animal, assim como o registro dos estabelecimentos industriais.
Decreto-Lei ne 4.113/42, propaganda de produtos farmacêuticos e dos profissionais de saúde

Decreto no $19.604 / 31$, alimentos

Decreto ne $780 / 36$

e Decreto ne 891/38, entorpecentes

Decreto-Lei ne 7.841/45, Código de Águas Minerais

Decreto no 20.397/46, regulação da indústria farmacêutica

Lei n $1.283 / 50$, alimentos 
Lei n² 1.944/53, iodaçăo do sal de cozinha

1953, Ministério da Saúde, Lei n² 1920/53

1961, Laboratório Central de Controle de Drogas, Medicamentos e Alimentos (LCCDMA)

1957, Serviço Nacional de Fiscalização da Medicina e Farmácia (SNFMF), Decreto ne $41.904 / 57$

1961, Código Nacional de Saúde

Decreto ne 50.040/61, aditivos químicos em alimentos

Codex Alimentarius

denúncia na área de alimentos e de medicamentos
Atribuiu-se esse controle ao Ministério da Agricultura, cabendo a Estados e Municípios fiscalizar os produtos de circulação restrita aos seus territórios; o conjunto da legislação e a estrutura centralizada, visavam, principalmente, atender às exigências dos países importadores - sobretudo dos Estados Unidos - e tornar a carne brasileira mais competitiva no mercado internacional. A Lei ne 1.944/53 tornou obrigatória a iodação do sal de cozinha, com fins de controle do bócio endêmico, inicialmente nas áreas de maior prevalência da doença, para depois estender-se para todo o país. Essa foi uma das mais importantes iniciativas na área de alimentos, para controle de uma doença.

Em 1953 foi criado o Ministério da Saúde (Lei n 1920/53), que manteve em sua estrutura o Serviço Nacional de Fiscalização da Medicina (SNFM) e o Serviço de Saúde dos Portos. No ano seguinte criou-se o Laboratório Central de Controle de Drogas e Medicamentos (LCCDM), para realizar análises e estabelecer padrões. Em 1961 o LCCDM incorporou a área de alimentos, passando a incumbir-se da análise prévia e do registro de produtos alimentícios, transformando-se no Laboratório Central de Controle de Drogas, Medicamentos e Alimentos (LCCDMA). Em 1957 o SNFM se transformou em Serviço Nacional de Fiscalização da Medicina e Farmácia (SNFMF), incorporando o LCCDMA, as Comissões de Biofarmácia e de Revisão da Farmacopéia, essas últimas como instâncias deliberativas (Decreto n 41.904/57).

Em 1961, ao final do governo Kubitschek, se regulamentou o Código Nacional de Saúde; esse Código nasceu da Lei n².312/54, que estabelecia normas gerais sobre defesa e proteção da saúde. E atribuiu ao Ministério da Saúde extenso espectro de atuação na regulação de alimentos, estabelecimentos industriais e comerciais, pessoal, veículos, e na distribuição, na propaganda comercial e no controle de resíduos de pesticidas. Desde então, o controle de alimentos industrializados se dividiu entre os Ministérios da Saúde e da Agricultura, gerando-se, muitas vezes, conflitos de competências ou indefinições. Nesse período, surgiu o Decreto n 50.040/61, estabelecendo normas reguladoras do emprego de aditivos químicos em alimentos e criando a Comissão Permanente de Aditivos para Alimentos.

A partir do começo dos anos 1960, a área de alimentos passou a sofrer muita influência do Codex Alimentarius internacional, que reúne normas para o comércio internacional de alimentos, e estimula o controle sobre os riscos relacionados ao consumo desses produtos.

Vale notar que o começo da década de 1960 sofreu o impacto da denúncia de graves acontecimentos na área de alimentos e de medicamentos: as mortes por consumo de peixes contaminados com mercúrio, no Japão; as mortes de animais que se alimentaram com ração com afla- 
toxinas; a revelação da contaminação da carne brasileira com fármaco anabolizante; o nascimento de bebês malformados, em virtude do uso da talidomida.

Nos anos que precederam o golpe militar alguns fatos importantes marcaram a cena da política de saúde. Propostas de descentralização e de municipalização dos serviços dominaram os debates das Conferências Nacionais de Saúde de 1962 e 1963. Deu-se a instalação das Comissões Parlamentares de Inquéritos sobre o comportamento da indústria farmacêutica no País e a criação do Grupo Executivo da Indústria Farmacêutica (GEIFAR) para disciplinar o setor e controlar os abusos.

Houve a regulamentação de importantes áreas. Entraram em vigência normas técnicas para orientar a organização, o funcionamento e a fiscalização das instituições de assistência médico-social (Decreto n 52.464/63); para o controle dos produtos cosméticos e de higiene e da atividade hemoterápica e do sangue; para a vigilância de portos e fronteiras e saúde dos imigrantes, criando-se para isso as Inspetorias de Saúde dos Portos, nas várias regiões do País (Decreto n 57.743/66).

Depois de instaurada a ditadura, em 1964, o país passou a ser conduzido sob a égide do binômio desenvolvimento e segurança. Esse período corresponde ao aumento da abrangência do campo de ação da Vigilância Sanitária, com a incorporação de novos objetos e práticas de controle, acompanhando o crescimento da produção e do consumo de produtos e serviços de interesse sanitário. O governo militar promulgou uma nova Constituição e o decreto-lei, instrumento editado pelo Poder Executivo, voltou a ser utilizado como instrumento de regulação, ao invés da lei. Consolidou-se, no final do período, o conceito de vigilância no controle de doenças transmissíveis e o termo Vigilância Sanitária passou a denominar o conjunto de ações nas áreas de portos e fronteiras. Esse conceito se ampliou, na década de 1970, para incluir o controle sanitário de produtos e serviços de interesse da saúde. Nesse período também ocorreu a regulamentação do exercício de várias profissões da área da saúde, através da criação dos Conselhos Federais e Regionais.

\section{De 1967 a 1988}

O período de 1968 a 1974 caracterizou-se por acelerado crescimento da economia, com base na associação com o capital internacional, violenta repressão aos movimentos sociais e migração de expressivos contingentes da população rural para os grandes centros urbanos, em decorrência da capitalização da agricultura. A conjuntura pós-1974, caracterizada pelo fim do "milagre econômico", foi marcada pela crise
Decreto ne 52.464/63, fiscalização das instituiçōes de assistência médico-social

Decreto ne 57.743/66, Inspetorias de Saúde dos Portos

década de 1970 , criaçăo dos Conselhos Federais e Regionais 
complexo

médico-industrial

Decreto-Lei no 200/67, reforma administrativa federal

Decreto-Lei no 209/67, Código Brasileiro de Alimentos

farmacovigilância econômica e social e pelas reformas no setor saúde. Com o crescimento da medicina curativa, individual, no setor previdenciário, conformaram-se as bases para a expansão da produção e do consumo no âmbito do complexo médico-industrial, complexo que inclui medicamentos, equipamentos, aparelhos e instrumentos usados na assistência médica.

Com a reforma administrativa federal de 1967 - regida pelo Decreto-Lei ne 200/67, que pretendia modernizar o país - o campo de ação do Ministério da Saúde sofreu redefinições. Couberam-lhe a formulação e a coordenação da política nacional de saúde, o controle de drogas, medicamentos e alimentos e a Vigilância Sanitária de fronteiras, portos e aeroportos. Com a reorganização de 1970, aprovada pelo Decreto-Lei ne 66.623/70, nasceu a Secretaria de Saúde Pública, que abrigou a Divisão Nacional de Fiscalização, à qual ficaram subordinados o Serviço Nacional de Fiscalização da Medicina e Farmácia (SNFMF), o Serviço de Saúde dos Portos (SSP), o Laboratório de Controle de Drogas, Medicamentos e Alimentos (LCCDMA), a Comissão Nacional de Fiscalização de Entorpecentes (COFEN) e a Comissão Nacional de Hemoterapia (CNH). A Comissão Nacional de Normas e Padrões para Alimentos (CNNPA) e a Comissão Nacional de Alimentação (CNA) permaneceram na Divisão de Organização Sanitária.

O painel normativo na área de alimentos foi muito modificado com a instituição do Código Brasileiro de Alimentos (CBA), pelo Decreto-Lei n 209/67. Esse Código continha as normas de defesa e proteção da saúde individual e coletiva, desde a produção até o consumo de alimentos; embora prevista nas normas, devido a limitações institucionais, só no começo da década de oitenta os Estados passaram a ter participação rẹlevante no processo de registro dos produtos e de autorização de funcionamento de estabelecimentos. Cerca de dois anos depois, o DecretoLei nะ 986/69 revogou o CBA, introduziu o conceito de padrão de identidade e qualidade e instituiu as normas básicas sobre alimentos, em vigor até hoje. Nenhum dos dois Decretos menciona as competências do Ministério da Agricultura.

Na década de 1970, a Organização Mundial da Saúde editou resoluções sobre condições higiênicas na cadeia de produção e na manipulação de alimentos, e sobre os efeitos, na saúde, das técnicas modernas da industrialização de alimentos, inclusive de resíduos, aditivos e contaminantes; essas resoluções influenciaram as medidas de regulamentação em nosso país.

No campo dos medicamentos, nasceu, em 1971, a Central de Medicamentos. A CEME, além de regular a produção e a distribuição de medicamentos, deveria dotar o país de um sistema de farmacovigilância, pois havia grande preocupação no plano mundial com os efeitos do 
lançamento no mercado de inúmeros fármacos muito potentes, e pouco conhecidos, em termos toxicológicos.

A partir de 1973 se iniciou uma fase de importante revisão da legislação sanitária, com a edição de leis e decretos que vigoram até os dias de hoje. Destacam-se as Leis n 5.991/73, n 6.360/76 e n 6.368/76 e a Lei n 6.437/77. Isto se deu, também, em vários outros países, sob estímulo da OMS, cujas legislações continham inúmeras lacunas.

Inaugurou esse processo a publicação da Lei n 5.991/73, de controle sanitário do comércio de drogas, medicamentos, insumos farmacêuticos e correlatos. Esta lei revogou a ultrapassada regulamentação de 1931, estendendo sua ação para o comércio atacadista, o distribuidor, o representante, o importador e o exportador. Entre seus aspectos inovadores, destacam-se a explicitação da finalidade dos produtos de interesse da saúde, a necessidade de obediência a padrões de qualidade e o estabelecimento da colheita periódica de amostras para exames laboratoriais, prática até então sob o juízo da autoridade sanitária.

No decorrer dos trabalhos da CPI do Consumidor, que levantou denúncias sobre as práticas comerciais da indústria farmacêutica, o Poder Executivo encaminhou ao Congresso o anteprojeto que originou a Lei n 6.360/76, chamada Lei de Vigilância Sanitária. Esta lei normatiza as operações industriais a que se sujeitam os medicamentos, as drogas, os insumos farmacêuticos, os correlatos, os cosméticos, os produtos de higiene e os perfumes, os saneantes domissanitários, as embalagens e rotulagens, os estabelecimentos produtores, os meios de transporte e a propaganda. A Lei consagrou a Vigilância como atividade permanente, fundamentada no controle de qualidade e atribuiu ao produtor a responsabilidade de informar sobre as reações adversas aos medicamentos.

A seguir, sancionou-se a Lei ne $6.368 / 76$, voltada para o controle das substâncias tóxicas e entorpecentes, controle esse efetuado com participação de vários setores. A esta Lei se seguiram várias instruções e portarias, para regulamentação dos diferentes elos da cadeia de produção, distribuição e uso dessas substâncias.

A Lei ne 6.437/77 atualizou as disposições penais e administrativas, caracterizando trinta e um tipos de infrações sanitárias em geral - entre as quais as da área da Vigilância - e discriminando as respectivas penalidades. Esta Lei é um instrumento de utilidade abrangente até os dias atuais e trata do processo administrativo, da aplicação do auto de infração, da notificação, da defesa ou impugnação, da apreensão de amostras, da inutilização de produtos, do cancelamento de registro, etc.

O Decreto n 79.056/76 formalizou a nova estrutura do Ministério da Saúde, na qual o campo do controle sanitário passou à condição de secretaria ministerial, a Secretaria Nacional de Vigilância Sanitária. Se,
Lei no 5.991/73, comércio de drogas, medicamentos, insumos farmacêuticos e correlatos

Lei no 6.360/76, Lei de Vigilância Sanitária

Lei ne 6.368/76, substâncias tóxicas e entorpecentes

Lei n 6.437/77, infraçōes sanitárias

Decreto ne 79.056/76, nova estrutura do Ministério da Saúde 
1981, Instituto Nacional de Controle de Qualidade em Saúde (INCQS) por um lado, a nova estrutura representou o reconhecimento da relevância do setor, por outro lado sedimentou a cisão com a Vigilância Epidemiológica, desperdiçando-se, assim, o potencial de emprego dos métodos epidemiológicos nas práticas da Vigilância Sanitária. O Decreto previa a substituição das comissões ministeriais por Câmaras Técnicas, voltadas para objetos específicos, com composição ampla e funções consultiva e normativa. Consolidaram-se, no texto legal, preocupações com riscos, inocuidade e nocividade dos produtos, e se tomaram providências preliminares para a instalação de um sistema nacional de vigilância farmacológica, providências que, lamentavelmente, não saíram do papel. O LCCDMA foi transferido para a Fundação Oswaldo Cruz, onde renasceu, em 1981, com estrutura moderna e um novo nome Instituto Nacional de Controle de Qualidade em Saúde/INCQS. A SNVS estruturou-se em divisões especializadas, que passaram a ser conhecidas pelas suas siglas: DINAL, DIMED, DISAD, DICOP e DIPAF.

Ainda na década de 1970 houve intensa produção de decretos, portarias e resoluções normativas sobre edificações destinadas a serviços de saúde; condições sanitárias de exercício de profissões e ocupações técnicas; potabilidade e fluoretação da água nos sistemas de abastecimento; princípios de higiene nas operações com alimentos; registro de saneantes domissanitários; rotulagem de agrotóxicos; enquadramento de correlatos, quanto ao registro e à prescrição; licenciamento de unidades hemoterápicas; tipificação dos medicamentos, quanto à exigência de receita médica para a compra; experimentação terapêutica de substância nova; inspeção sanitária nas indústrias farmacêuticas; autorização para produção de matérias-primas, insumos farmacêuticos e aditivos; exames médicos para ingresso de estrangeiros no país; controle e prevenção de infecções hospitalares e seleção de germicidas.

A década de 1980 se caracterizou pela retomada dos movimentos em direção ao exercício da cidadania e à redemocratização da sociedade brasileira, consagrados na campanha pelas eleições diretas para a Presidência da República e pela instalação da Assembléia Nacional Constituinte. O período também imprimiu suas marcas na história da Vigilância Sanitária, que se torna mais conhecida, revelando as contradições de um Estado a oscilar entre a proteção à saúde da população e os interesses da produção e da venda de mercadorias e de serviços. A estruturação de inúmeros órgãos estatais, ou da sociedade civil - tais como o Conselho de Defesa do Consumidor, os PROCONs, as delegacias e comissões, o Instituto Brasileiro de Defesa do Consumidor (IDEC) e outros - forçaram o governo a pender em direção ao lado da balança onde está o cidadão. Em 1985 o Decreto ne 91.469 criou o Conselho Nacional de Defesa do Consumidor, para assessorar a Presidência da 
República. E a Lei ne 7.347/85 disciplinou a ação civil pública de responsabilidade por danos causados ao meio ambiente, ao consumidor, a bens e direitos de valor artístico, estético e turístico; essa Lei constitui um marco na evolução legislativa no campo dos direitos coletivos.

O primeiro governo civil, instalado em 1985, chamado Nova República, incorporou técnicos do movimento pela reforma sanitária. Pela primeira vez, uma equipe de sanitaristas assumiu o órgão nacional de Vigilância Sanitária. E compartilhou a sua ação com a dos profissionais das Secretarias Estaduais de Saúde, na busca da ruptura do modelo autoritário e centralizador da Vigilância e da construção de um novo modo de operar o setor; a realização da Conferência Nacional de Saúde do Consumidor, em 1986, expressou esse projeto. Até o afastamento da equipe responsável pela Vigilância Sanitária, em 1987, em meio a conflitos entre a nova concepção e a orientação do Ministro da Saúde na época, alguns episódios alcançaram a grande imprensa: a contaminação de sucos e gelatinas com excesso de conservantes; as manobras da indústria para impedir o controle dos medicamentos psicotrópicos e entorpecentes; o acidente radioativo em Goiânia; a controvérsia sobre a liberação do uso de adoçantes artificiais em refrigerantes; as precárias condições de fabricação de bolsas de sangue. Tais episódios geraram intensa produção normativa para regulamentar uma grande variedade de produtos, entre os quais os alimentos para lactentes, e diversos serviços, tais como os que utilizam equipamentos que emitem radiações ionizantes, as creches, os bancos de leite humano, e outros.

Encerraram o período o enfrentamento da questão do fumo e a conseqüente limitação da sua publicidade, e a publicação da Resolução $\mathrm{n}{ }^{2} 1 / 88$, com orientações para garantir a conduta ética e a segurança na pesquisa que envolve seres humanos.

\section{De 1988 a 1999}

Ao final da década de 1980, em paralelo ao processo de redemocratização, o País se via mergulhado na inflação, na recessão e no desemprego. As eleições de 1989 levaram ao poder um candidato desvinculado dos partidos políticos tradicionais que seduziu grande parte da população com um discurso aparentemente modernizante, governou por dois anos e foi afastado, através de impeachment. Durante o curto período do Governo Collor de Mello, de orientação neoliberal, houve retrocesso significativo na Vigilância, em função do Projeto Inovar, cujo objetivo central era dar resposta ágil às petições dos produtores, desconsiderando as análises técnico-científicas. Assim, foram liberados, irregularmente, registros para uma enorme quantidade de produtos,
Lei ne 7.347/85, disciplina a ação civil pública de responsabilidade por danos ao meio ambiente e ao consumidor

1986, Conferência Nacional de Saúde do Consumidor

Resolução n 1/88, pesquisa em seres humanos

Projeto Inovar 


\section{Mercosul}

enfoque de risco

consulta pública

descentralização

Lei no 8.078/90,

Código de Defesa do Consumidor sobretudo medicamentos. Ignorou-se a natureza protetora das ações de Vigilância, como se a doutrina do liberalismo e a desregulamentação pudessem sobrepor-se às práticas da Vigilância, como se fosse possível esquecer que o modo de produção cria lógicas que entram em choque com os interesses sanitários da coletividade.

Seguindo os ditames da Constituição Federal de 1988, que afirmou ser a saúde um direito de todos e destacou as atribuições da Vigilância Sanitária como obrigação do Estado, produziu-se intensa atividade regulatória. Este efeito foi estimulado, também, pela criação do mercado comum do Cone Sul, o Mercosul, que demandou intenso trabalho de harmonização de normas entre os vários países, trabalho concentrado na qualidade da produção e nas boas práticas de fabricação.

Tomado o período em seu conjunto, é possível afirmar que, nele, a visão da Vigilância como ação da cidadania, e sua fundamentação na epidemiologia e no enfoque de risco, tornaram-se mais consistentes. Aumentou a participação da sociedade civil e em órgãos colegiados e introduziu-se o hábito de submeter as regulamentações à consulta pública, através do diário oficial, antes da publicação definitiva. Deramse alguns passos rumo à descentralização para os Estados e Municípios, e iniciou-se a estruturação de programas de formação de recursos humanos. Ganharam funcionalidade algumas estruturas de assessoramento no plano federal e alguns órgãos se tornaram mais permeáveis à participação da sociedade.

Entre os principais marcos normativos do período merecem destaque: a Lei ne 8.078/90, que estabelece normas de proteção e defesa do consumidor; a Lei ne 8.080/90, que organiza o Sistema Único de Saúde; a Portaria 1.565/94, que define o Sistema Nacional de Vigilância Sanitária, estabelecendo as bases para a descentralização de serviços e ações; o Decreto ne 793/93, que estabeleceu a obrigatoriedade do emprego da denominação genérica de medicamentos; e a Portaria n 1.428/93, que aprovou diretrizes e regulamentos para a Vigilância de alimentos.

A Lei n 8.078/90, o chamado Código de Defesa do Consumidor, reforçou a legislação de proteção e defesa da saúde, reafirmando a responsabilidade do produtor pela qualidade do produto e do serviço e the impondo atividades de informação ao consumidor. O Código introduziu a "inversão do ônus da prova", isto é, em caso de alegação de impropriedade, cabe ao fabricante provar ser o produto bom para o consumo. O conceito de vulnerabilidade do consumidor no mercado é um dos princípios de sustentação dos direitos do consumidor, e confirma a essencialidade da regulação das relações produção-consumo para a proteção do elo mais frágil. A legislação destina-se, também, a proteger interesses econômicos gerais, pois práticas abusivas contra o consumi- 
dor podem ameaçar a confiança nos produtos e nos fabricantes, e levar a prejuízos econômicos.

A Lei ne 8.080/90, do SUS, inaugurou uma nova condição jurídicoformal para a Vigilância Sanitária; nela destaca-se a abrangência das ações de Vigilância, ao incluir, entre as competências do SUS, a vigilância de produtos, de serviços, dos ambientes e dos processos de trabalho, através de execução direta ou mediante a participação de outros setores. Ademais, atribuiu-se à Vigilância o papel de coordenar a Rede Nacional de Laboratórios para a Qualidade em Saúde.

Uma das mais importantes, e polêmicas, medidas do período 1988-1995 foi a edição do Decreto n² 793, no Governo Itamar Franco, que firmou a obrigatoriedade de se dar destaque ao nome genérico, na rotulagem dos medicamentos, assim como a de se usar essa denominação na prescrição. A polêmica deve-se ao fato de essa regra, que resulta em diminuição dos preços dos medicamentos, contrariar os interesses das indústrias, pois as mesmas se valem dos nomes de marca nas suas estratégias de mercado.

Também a área de controle de alimentos experimentou avanços consideráveis. Houve definição das atribuições dos Ministérios da Agricultura e da Saúde, continuando as bebidas como matéria de competência de ambos. Porém, a regulamentação do uso de edulcorantes em refrigerantes significou uma vitória das indústrias de bebidas e de aditivos. Introduziu-se a obrigatoriedade da colocação nos rótulos das bebidas alcoólicas de advertência sobre seus prejuízos à saúde. Houve regulamentação de complementos e suplementos nutricionais, de alimentos para fins especiais, de alimentos para os lactentes, e atualização dos padrões da água para consumo humano e da adição de iodo ao sal.

É preciso destacar a edição da Portaria 1.428/93 que aprovou o Regulamento Técnico para Inspeção Sanitária de Alimentos, as Diretrizes para o Estabelecimento de Boas Práticas de Produção e de Prestação de Serviços na área de Alimentos, e o Regulamento Técnico para o Estabelecimento de Padrão de Identidade e Qualidade para Serviços e Produtos na área de Alimentos. Assim, introduziu-se nas normas o enfoque de risco epidemiológico, a ser incorporado ao planejamento das inspeções e ao estabelecimento de prioridades, por meio do Sistema de Avaliação dos Perigos em Pontos Críticos de Controle, instrumento que permite controlar a contaminação dos alimentos.

Num curto espaço de tempo foram produzidas, ou reatualizadas, regulamentações sobre um amplo leque de objetos de relevância sanitária, não apenas os tradicionais, mas também alguns contemporâneos: medicamentos fitoterápicos, hepatoprotetores e antidiarréicos; sangue e hemoderivados; licenciamento de estabelecimentos de saúde, sobretudo hospitais; proteção radiológica; clínicas geriátricas; infecções hospitala-
Lei ne 8.080/90, SUS

Decreto no 793, nome genérico dos medicamentos

edulcorantes em refrigerantes

bebidas alcoólicas

Portaria 1.428/93, Regulamento Técnico para Inspeção Sanitária de Alimentos 
Programa Nacional de Inspeçāo em Indústrias Farmacêuticas e Farmoquimicas (PNIFF)

produtos falsificados e defeituosos

Lei ne 9.677/98, delitos hediondos

Lei ne 9.695/98, novas penalidades res; produtos de higiene, cosméticos, perfumes e produtos de uso infantil; saúde dos imigrantes e vigilância nos portos; controle dos agrotóxicos, inclusive com a reavaliação dos organoclorados; correlatos; engenharia genética e biossegurança; sistemas de monitoramento e farmacovigilância.

Nesse período também houve a formulação do Sistema Nacional de Vigilância Sanitária e a determinação de se encaminharem todas as petições aos órgãos estaduais e federais - Portaria Ministerial ne 1.565/ 94 e Portaria SVS no 109/94, respectivamente. E, impulsionada pelos ditames do Mercosul, criaram-se instrumentos para aprimorar a qualidade dos produtos, a saber, os guias de boas práticas de fabricação e os roteiros para inspeção de indústrias de medicamentos, domissaneantes e cosméticos. Criou-se também o Programa Nacional de Inspeção em Indústrias Farmacêuticas e Farmoquímicas/PNIFF, vigente até os dias atuais, embora pouco ativo.

De um modo geral, o aperfeiçoamento da Vigilância Sanitária, e sua evolução normativa, não foram devidamente acompanhados por transformações profundas nas ações dos governos, nos planos federal, estadual ou municipal. Ao longo do tempo, cresceram uma volumosa demanda do setor produtivo, e a percepção social e sanitária da importância da Vigilância Sanitária. E, sem que houvesse, correspondentemente, políticas públicas de fôlego para capacitação institucional, aumentaram as críticas sobre a atuação da Vigilância Sanitária no país e surgiram propostas de reformulação do modelo de organização e de operação da mesma. No final dos anos noventa, o derrame no mercado, em níveis alarmantes, de produtos falsificados e defeituosos, por falta de cumprimento das boas práticas de fabricação, tornou-se um escândalo, fragilizou a imagem da instituição, e do próprio segmento produtivo, e impulsionou a edição de muitas normas e a mudança do modelo da instituição. Essa mudança ocorreu no momento em que estava em curso a reforma do Estado, tendo por eixo as privatizações, a descentralização de funções para os Estados e Municípios e a ampliação das responsabilidades, no plano federal, de controle de áreas estratégicas.

Entre as normas elaboradas para dar respostas à crise, destaca-se a Lei n 9.677/98. Esta Lei, que alterou dispositivos do Código Penal para incluir a falsificação (e a corrupção, a adulteração ou a alteração) de substâncias ou produtos de interesse da saúde, na classificação dos delitos hediondos, aumentando-se as penalidades por esses delitos; a Lei n 9.695/98, alterando a Lei 6.437/77, aumentou os valores de multas e introduziu novas penalidades, como a intervenção no estabelecimento que receba recursos públicos.

Outras normas sobre aspectos específicos do controle dos medicamentos foram editadas mediante portarias. Além disso, passou-se a exi- 
gir Autorização de Funcionamento das Empresas Transportadoras de Produtos Farmacêuticos e Farmoquímicos - um preceito legal que não vinha sendo cumprido - e se estabeleceu um Guia de Boas Práticas de Transporte e um de Boas Práticas de Distribuição.

Neste momento criou-se a Agência Nacional de Vigilância Sanitária. A ANVS deveria ser uma autarquia com um modelo administrativo mais ágil, com independência financeira e estabilidade de seus dirigentes. Lamentavelmente, o governo preferiu não atender a uma recomendação da 10a Conferência Nacional de Saúde, de realização de uma Conferência Nacional de Vigilância à Saúde, de modo a se ampliar a construção democrática de um Sistema Nacional de Vigilância Sanitária, sob as diretrizes da Portaria 1.565/94, com a participação dos três niveis de governo. Em 27 de janeiro de 1999, o Congresso Nacional promulgou a Lei ne 9.782; esta Lei dispõe sobre o Sistema Nacional de Vigilância Sanitária, cria a Agência Nacional de Vigilância Sanitária (ANVS), que substitui a Secretaria Nacional, e dá outras providências na sua área de atuação. A Lei definiu que a ANVS terá por finalidade institucional "promover a proteção da saúde da população, por intermédio do controle sanitário da produção e da comercialização de produtos e serviços submetidos à Vigilância Sanitária, inclusive dos ambientes, dos processos, dos insumos e das tecnologias a eles relacionados, bem como o controle de portos, aeroportos e fronteiras."

Definiram-se, ainda, novas atribuições da Vigilância Sanitária, como o monitoramento da qualidade de bens e produtos, por meio de programas especiais, sistemas de vigilância farmacológica e toxicológica, e sistema de informação, e o controle de produtos fumígenos, como os derivados do tabaco, e de resíduos de medicamentos veterinários em alimentos. Entretanto, não se incluíram as temáticas do meio ambiente e da ecologia humana, da saúde do trabalhador e da informação e educação sanitária da população e dos consumidores. Completando essas reformulações legislativas a Lei ne 9.787/99 estabeleceu os medicamentos genéricos e dispôs sobre a utilização de nomes genéricos em produtos farmacêuticos, assim resgatando parte dos preceitos estabelecidos no Decreto ne 793/93.

Vários segmentos da organização social brasileira deverão estar representados no Conselho Consultivo da ANVS, e se encontra em curso o processo de descentralização das ações e serviços de saúde no Brasil. Assim, espera-se que a influência da sociedade civil na política de saúde, através deste Conselho, do Conselho Nacional de Saúde, dos conselhos estaduais e municipais, possa fomentar um processo de verdadeiro avanço nas práticas da Vigilância Sanitária, cuja importância para a saúde e a qualidade de vida de toda a população é imensa. empresas transportadoras de produtos farmacêuticos e farmoquímicos

Lei no 9.782, Agência Nacional de Vigilância Sanitária 


\section{Referências bibliográficas}

BODSTEIN, R. de A. (org), 1987. História e saúde pública: a política de controle do câncer no Brasil. Rio de Janeiro: PEC-ENSP.

BRAGA, J.C.S; PAULA, S.G., 1985. Sáude e previdência: estudos de política social. 2a edição, São Paulo: Hucitec.

COSTA, E. A., 1998. Vigilância sanitária e proteção da saúde. São Paulo. [Tese de Doutoramento - Faculdade de Saúde Pública da USP]. p. 327.

COSTA, E. A., 1999. A Vigilância Sanitária e a Saúde do Consumidor. In: Rouquayrol, M.Z. \& Almeida Filho, N. A. Epidemiologia e Saúde. 5a edição, Rio de Janeiro: MEDSI - Editora Médico Científica. pg 327-352.

COSTA, N. R., 1985. Lutas urbanas e controle sanitário: origens das politicas de saúde no Brasil. Petrópolis:Vozes/ABRASCO.

FOUCAUlT, M., 1993. Microfisica do Poder. 11" edição, Rio de Janeiro: Graal. p. 79-98: O nascimento da medicina social.

MACHADO, R. et al., 1978. Danação da Norma: a Medicina Social e a Constituiçâo da Psiquiatria no Brasil. Rio de Janeiro: Graal.

PRADO JUNIOR, C., 1981. História econômica do Brasil. 2a edição, São Paulo: Brasiliense. ROSEN, G., 1994. Uma história da Saúde Pública. São Paulo: UNESP/HUCITEC, ABRASCO.

WALDMAN, E., 1991. Vigilância epidemiológica como prática de Saúde Pública. São Paulo [Tese de Doutoramento - Faculdade de Saúde Pública da USP, Departamento de Epidemiologia]. 


\section{Conceitos e área de abrangência}

Ediná Alves Costa

Os conceitos que permeiam as normas de Vigilância nem sempre são claros, em virtude da natureza dos seus objetos de cuidado e também da natureza da linguagem jurídica, que se nutre da linguagem natural. Em decorrência, fala-se, em termos jurídicos, de conceitos indeterminados e de conceito estipulativo.

Os conceitos indeterminados, ou abertos, compreendem conceitos de experiência ou de valor. Quando o respectivo termo não está definido estipulativamente (na expressão "para os efeitos dessa lei entende-se por..."), o exame de um conceito desse tipo requer uma tarefa de preenchimento que se faz com a incorporação de elementos doutrinários e parâmetros buscados na realidade. Já o conceito estipulativo - que não se deve confundir com o conceito jurídico - corresponde a uma definição sobre determinado elemento que a norma jurídica faz, com o objetivo de superar a imprecisão, ou a ambigüidade, do termo correspondente ao conceito.

Estas questões ficam mais claras nos seguintes exemplos: a Lei ne 5.991/73, avançando em relação a diplomas legais anteriores, oferece um conceito estipulativo de medicamento, definindo-o como "produto farmacêutico, tecnicamente obtido ou elaborado, com finalidade profilática, curativa, paliativa ou para fins diagnósticos." Esta definição não corresponde, ainda, ao conceito de medicamento, pois, o conceito original de phármakon reconhecia no medicamento a mistura de dois elementos, remédio e veneno. Assim, o preenchimento do conceito de medicamento - que não é um produto qualquer, e sim um bem social cujo uso contém riscos, além de estar sob controle oficial e ter finalidade especificada -, inclui segurança, eficácia, inocuidade (no sentido de não ser nocivo, ter o mínimo possível de riscos). E sua produção e co- conceitos

indeterminados

conceito estipulativo 
mercialização, e seu uso, devem orientar-se pelo princípio do benefício. Esses elementos constam da Lei ne 6.360/76, cuja evolução ganhou impulso com a experiência negativa da talidomida, em todo o mundo.

Sem levar em conta a multidisciplinaridade da área, e a natureza da linguagem jurídica, a aproximação dos dois campos do saber - o da saúde e o jurídico - ainda é incipiente, e, em geral, as leis sanitárias não se expressam com a linguagem da área da saúde. Assim, no processo social e técnico-científico, o campo da Vigilância Sanitária incorpora termos nem sempre precisos. Mas, tal como as palavras e expressões jurídicas, suas significações são perfeitamente determináveis. Esses termos vão aproximando os campos de saber, e são fundamentais para a compreensão dos conceitos. Merecem destaque os seguintes termos:

\section{Controle e fiscalização}

O termo controle é empregado, comumente, para ações sanitárias sobre pessoas, atividades, substâncias, produtos, serviços e órgãos, para que estes não se desviem de normas pré-estabelecidas. E também para designar ações sobre doenças e agravos, agentes nocivos ao homem agentes animais e vegetais - causadores de doenças e prejuízos econômicos nas atividades produtivas, a fim de que suas freqüências não se desviem da normalidade, avaliada através de medidas de incidência e prevalência. O termo apareceu inicialmente no Código Nacional de Saúde, em 1961. Na legislação específica de Vigilância Sanitária, o termo surgiu com as Normas Técnicas Especiais sobre Aditivos, publicadas concomitantemente ao Código de 1961, e se ampliou ao controle de fabricação e venda, ao controle do consumo, à análise de controle etc, que são processos mais gerais do âmbito da Vigilância Sanitária.

No campo da Vigilância Sanitária, controle e fiscalização se confundem. Mas controle é mais amplo, pois inclui a fiscalização e se estende desde a regulamentação até ações educativas, e de informação ao consumidor. Fiscalização é ação verificadora do cumprimento da norma, e se dá, muitas vezes, mediante a inspeção de estabelecimentos, atividades e ambientes. O termo fiscalização confunde-se com a própria Vigilância Sanitária, pois esteve incluído no nome do órgão federal da década de 1920 até a de 1970. Até hoje, muitos órgãos estaduais e municipais incluem esse termo na sua denominação. A expressão fiscalização do exercício da medicina mantem, na origem, identidade com o "poder cego" da fisicatura durante o período do Brasil colônia, isto é, mantem a força de arbítrio da antiga noção de poder de polícia desvinculada de 
um saber, em estreita correlação com a cobrança de emolumentos. A Lei ne 5.991/73 inova na denominação do conjunto das ações de Vigilância Sanitária, sendo usado o termo controle sanitário. No último reordenamento, quando se criou a Agência Nacional de Vigilância Sanitária, e as taxas passaram a ser determinantes para a autonomia financeira do órgão, denominou-se taxa de fiscalização, indistintamente, os valores cobrados por quaisquer ações.

O controle inclui licença, autorização de funcionamento e registro, meios utilizados pela Administração Pública para intervir nas atividades dos particulares, e as adequar aos interesses coletivos. Além da responsabilidade técnica existem, ainda, análises fiscal, prévia e de controle de produtos. Podemos chamar esses conceitos de conceitos operativos, através dos quais a Vigilância desenvolve sua ação de proteger a saúde e elevar a qualidade de vida.

\section{Defesa e proteção da saúde}

A expressão apareceu nas Constituições de 1937, 1946,1967 e 1988 e diz respeito à competência do Estado para legislar sobre a saúde. E ganhou ênfase na década de 1950, com a criação do Ministério da Saúde e de órgãos e estruturas para acompanhar e apoiar o projeto de desenvolvimento industrial. Nesse contexto, quando o aparato estatal em Saúde Pública se ampliou, a expressão defesa e proteção demarcava um espaço da saúde, seja para legitimação retórica das ações de assistência à saúde, ou para criar condições sanitárias que permitissem o desenvolvimento econômico no país. No contexto da defesa e proteção do país, sob a doutrina da segurança nacional, usada no período ditatorial, após a década de 1960, várias normas técnicas do Código de Saúde são consideradas normas de defesa e proteção da saúde relativas a alimentos, saneantes, cosméticos e produtos de higiene, correlatos etc.

Nos anos recentes aparecem as expressões defesa da saúde do consumidor e defesa e proteção da saúde do consumidor, defesa da saúde do usuário; proteção à saúde pública; proteção de direitos e bem-estar; defesa e proteção da saúde individual e coletiva; proteção do meio ambiente; proteção de florestas, de ambiente hídrico e de outros ecossistemas; proteção da qualidade ambiental; proteção da vida e saúde do homem, dos animais e das plantas e do meio ambiente etc. A ampliação da noção de defesa e proteção da saúde se dá com a apropriação social da abrangência do conceito de saúde como também da dimensão coletiva e do ambiente, a ser protegido e defendido de agressões resultantes do modo de operação do sistema produtivo. 


\section{Higiene}

Este termo aparece desde os Regulamentos de 1923 e de 1931, como parte da Higiene do Trabalho, a que todos os estabelecimentos industriais, inclusive os da indústria farmacêutica, deviam obedecer. Mantendo-se fiel às suas origens ligadas à limpeza (limpeza espiritual que se estende à física), o termo higiene se associava, predominantemente, a locais e alimentos, a meios de transporte e a veículos destinados ao transporte de produtos sujeitos à Vigilância Sanitária e ainda, em menor grau, aos manipuladores de alimentos. E assumia, amiúde, o sentido de asseio-higiene. A higiene é parte das condições sanitárias exigidas das embarcações e das áreas aeroportuárias, que a inspecão sanitária deve verificar. A higiene pessoal e ambiental é, ainda, finalidade de determinadas classes de produtos. O termo higiene sempre aparece nas normas de alimentos, seja como requisito do produto, seja dos locais onde são produzidos, manipulados ou envasados; e a noção atual de higiene neste campo contempla, além dos padrões microbiológicos, parâmetros em relação aos resíduos de pesticidas e outros contaminantes. A higiene da alimentação é preceito normativo que fundamenta o cancelamento, temporário ou definitivo, do registro de um dado alimento, e a interdição, ou a apreensão, de alimentos e bebidas.

\section{Inocuidade}

Termo usado em oposição a nocividade. Tem por referência a noção do que não causa dano a saúde, não é nocivo. É atributo dos produtos (cosméticos, medicamentos, etc) e também de materiais, equipamentos, utensílios e embalagens usadas no preparo, no fabrico, no envasamento ou acondicionamento e no transporte dos mesmos. No caso de alimentos refere-se apenas aos alimentos irradiados, aos aditivos e às embalagens, equipamentos e utensílios revestidos com produtos e substâncias específicas.

O termo inocuidade, quando diz respeito aos medicamentos e aos aditivos, aparece de modo incoerente nas normas de controle sanitário, face aos seus significados de inofensivo e inerte. A confusão se explica em virtude do aparecimento do termo na legislação de 1931 no sentido de inerte, como requisito dos materiais usados na fabricação de aparelhos, instrumentos, utensílios e vasilhames empregados no preparo, na fabricação, no envasamento e no acondicionamento das substâncias e produtos destinados ao uso farmacêutico. Esse termo, no sentido de inerte, não se aplica aos fármacos e às especialidades farmacêuticas. Portanto, seu significado correto corresponde ao da origem do termo, isto é, não-nocivo. 


\section{Nocividade}

A noção de nocividade permeia todo o campo do controle sanitário, sendo o fundamento da existência das ações do mesmo. Quando o Estado intervém em atividades de particulares visa evitar que a possível nocividade de produtos e serviços, apropriada por meio da noção de risco, prejudique a saúde individual, coletiva e ambiental. Nos textos normativos, um produto, uma substância podem ser nocivos, como também determinada prática, microrganismos ou seres vivos (neste último caso, aqueles que justificam a permissão para fabricação de agrotóxicos). A palavra nocividade vem do latim e significa o que prejudica, ou causa dano.

No campo da Vigilância Sanitária essa noção se amplia para abranger a nocividade que não decorre apenas de delinqüência sanitária, por adição ou supressão, mas se relaciona à evolução do conhecimento científico, que evidencia que determinado produto ou substância, até então considerado terapeuticamente útil, passa a ser nocivo à saúde. Graças à sua função protetora e preventiva, o aparato institucional pode, ante suspeita ou alegação de nocividade, ordenar a suspensão da fabricação e venda de produtos que se tornem suspeitos de serem nocivos à saúde humana, embora tenham registro.

A noção correspondente ao termo - sem definição nas normas -, parece ser socialmente definida, uma vez que tem sido usada para impor medidas de controle, tais como a proibição da fabricação e do uso de lança-perfume, por Jânio Quadros, em 1961, e as restrições, impostas gradualmente, ao uso do fumo e do álcool.

\section{Qualidade}

Diz respeito à noção de atributo intrínseco, presumivelmente esperado de bens materiais e imateriais relacionados com a saúde, sendo de responsabilidade do produtor e do prestador de serviços. As primeiras referências à qualidade, presentes nas normas, se referem à supressão de qualidade, e constam das definições de produtos fraudados, ou como especificações da Farmacopéia Brasileira, ou de outros códigos. O termo é escassamente referido nos Regulamentos de 1931 e de $1946 . \mathrm{Na}$ legislação de alimentos, introduzida em 1967, é um dos elementos a conformarem o padrão de alimento ou de aditivo, dito padrão de identidade e qualidade. Para compor este padrão, a norma determina a fixação de critérios de qualidade. O conceito de padrão de identidade e qualidade, ou padrão de qualidade, incorpora-se às normas editadas após a inovação. 
A qualidade deve ser verificada pelo Estado, através de análises laboratoriais, e é condição para a concessão do registro de um produto. Nos últimos anos, a qualidade se estabeleceu no discurso sanitário institucional, e se iniciou a incorporação do termo como qualidade de vida. O Decreto 109/91, reorganizou o Ministério da Saúde e atribuiu ao órgão federal responsável pela Vigilância Sanitária a promoção de auditorias para verificar a qualidade de produtos e serviços. Nos últimos anos, surgiu o conceito de padrão de identidade e qualidade de serviços na área de produtos alimentícios. O Código de Defesa do Consumidor e a Lei Orgânica da Saúde fundamentam as normas de melhoria da qualidade.

\section{Segurança}

O termo se liga, nos textos normativos, a categorias como trabalho, espaço, saúde e poder do Estado. Aparece, inicialmente, na legislação de 1961, ligado ao trabalho e ao meio-ambiente. Na Lei $6.360 / 76$ a segurança sanitária justifica a intervenção governamental na suspensão da fabricação e da venda de produtos suspeitos de serem nocivos à saúde humana. Nos últimos anos aparece a noção de enfoque de segurança, na Lei de Agrotóxicos, na Lei de Biossegurança e nas normas sobre as indústrias do âmbito do Mercosul. Atualmente, em países desenvolvidos, vem adquirindo consistência o conceito de segurança sanitária, cujo conteúdo, bem amplo, se refere ao presente e ao futuro e à toda a coletividade, e inclui as preocupações com produtos transgênicos.

\section{Risco}

É usado nas acepções da linguagem comum e no sentido epidemiológico. Diz respeito à probabilidade de ocorrência de eventos adversos relacionados a objetos submetidos a controle sanitário. O termo risco começou a aparecer no Código Sanitário de 1961, empregado erroneamente como risco da saúde. Refere-se à saúde do homem, mas também às dos animais e das plantas.

O termo risco é complexo e tem sido usado com significados distintos: como perigo ou ameaça (com relação, por exemplo, ao efeito danoso dos agrotóxicos, raticidas e inseticidas domésticos) e como causa de risco. A legislação mais recente procura utilizá-lo na forma de expressões mais precisas, tais como fatores de risco, grau de risco, potencial de risco, grupos de risco, gerenciamento de risco e risco potencial, este último como inerente a cada item no exame da qualidade e da segurança do 
produto e da segurança do trabalhador, em sua interação com os produtos e processos de fabricação.

\section{Área de abrangência}

Vistos os termos, relevantes para a compreensão dos conceitos essenciais da Vigilância Sanitária, a área de abrangência da mesma pode ser descrita assim:

- normalização e controle de bens, da produção, do armazenamento, da circulação, do transporte, da comercialização e do consumo de produtos de interesse da saúde, e de suas matérias-primas, coadjuvantes de tecnologias, equipamentos e processos;

- normalização e controle de tecnologias médicas, tanto de equipamentos como de procedimentos, dos mais rudimentares aos mais requintados, da chamada tecnologia de ponta;

- normalização e controle de serviços direta ou indiretamente relacionados com a saúde, prestados, direta ou indiretamente, pelo Estado e pelo setor privado. Sob o título de fiscalização das condições do exercício profissional, o Estado partilha responsabilidades com entidades corporativas, às quais se atribuiu, em época mais recente, parte dessas competências;

- normalização e controle específico de portos, aeroportos e fronteiras, de veículos, cargas e pessoas;

- normalização e controle de aspectos do ambiente, do ambiente de trabalho e da saúde do trabalhador. 


\section{Referências bibliográficas}

BODSTEIN, R. de A. (org), 1987. História e saúde pública: a política de controle do câncer no Brasil. Rio de Janeiro: PEC-ENSP.

BRAGA, J.C.S; PAULA, S.G., 1985. Sáude e previdência: estudos de política social. 2a edição, São Paulo: Hucitec.

COSTA, E. A., 1998. Vigilância sanitária e proteção da saúde. São Paulo. [Tese de Doutoramento - Faculdade de Saúde Pública da USP]. p. 327.

COSTA, E. A., 1999. A Vigilância Sanitária e a Saúde do Consumidor. In: Rouquayrol, M.Z. \& Almeida Filho, N. A. Epidemiologia e Saúde. 5a edição, Rio de Janeiro: MEDSI - Editora Médico Científica. pg 327-352.

COSTA, N. R., 1985. Lutas urbanas e controle sanitário: origens das politicas de saúde no Brasil. Petrópolis:Vozes/ABRASCO.

FOUCAULT, M., 1993. Microfísica do Poder. 11a edição, Rio de Janeiro: Graal. p. 79-98: O nascimento da medicina social.

MACHADO, R. et al., 1978. Danação da Norma: a Medicina Social e a Constituiçẫo da Psíquiatria no Brasil. Rio de Janeiro: Graal.

PRADO JUNIOR, C., 1981. História econômica do Brasil. 2a edição, São Paulo: Brasiliense. ROSEN, G., 1994. Uma história da Saúde Pública. Sâo Paulo: UNESP/HUCITEC, ABRASCO.

WALDMAN, E., 1991. Vigilância epidemiológica como prática de Saúde Pública. São Paulo [Tese de Doutoramento - Faculdade de Saúde Pública da USP, Departamento de Epidemiologia]. 


\title{
SUS, modelos assistenciais e Vigilância da Saúde *
}

\author{
Carmem Fontes Teixeira, Jairnilson Silva Paim, Ana Luiza Vilasbôas
}

\section{Introdução}

No processo de construção do Sistema Único de Saúde (SUS) o debate político-institucional tem privilegiado o financiamento e a gestão. Apesar da retórica governamental, tem sido negligenciada a questão dos modelos assistenciais, isto é, as formas de organização tecnológica do processo de prestação de serviços de saúde. O sistema de saúde brasileiro é palco da disputa entre modelos assistenciais diversos, com tendência à reprodução, conflitiva, dos modelos médico-assistencial privatista (ênfase na assistência médico-hospitalar e nos serviços de apoio diagnóstico e terapêutico) e sanitarista (campanhas, programas especiais e ações de Vigilância Epidemiológica e Sanitária), ao lado de alguns esforços de construção de "modelos" alternativos (Mendes, 1993; Paim, 1994).

Para além do intercâmbio de experiências e da elaboração de princípios e diretrizes gerais que norteiam as diversas iniciativas desencadeadas nos municípios, consideramos necessária a sistematização de elementos conceituais, metodológicos e instrumentais capazes de contribuir para a adoção de decisões e implementação de ações no âmbito municipal. Nosso propósito é a construção do(s) modelo(s) assistencial (ais) coerentes com a problemática de cada município e viáveis, do ponto de vista da disponibilidade de recursos e da capacidade técnica, gerencial e política dos sistemas municipais de saúde.

\footnotetext{
- Versão resumida do texto elaborado para a Oficina de Vigilância em Saúde do IV Congresso Brasileiro
} de Epidemiologia, publicado no Informe Epidemiológico do SUS, ano VII, n² 2, abril/jun 1998. construção de modelos assistenciais coerentes e viáveis 
construção de um modelo fundamentado na Vigilância da Saúde

\section{A Vigilância da Saúde no contexto da municipalização}

Durante a elaboração da NOB 001/96, além da tentativa de se estabelecer um critério populacional padrão para se definir o volume de recursos financeiros que caberia a cada município habilitado para as ações básicas, foram introduzidos "fatores de estímulo" à implementação de inovações; entre essas inovações o Programa de Saúde da Família (PSF) e as ações de Vigilância Epidemiológica e Sanitária.

Nesse contexto, o município tem condições de articular o conjunto das propostas, programas e estratégias que vêm sendo definidos no nível federal e, em vários estados. E de desencadear, em seu âmbito, um processo de reorientação do "modelo assistencial" do SUS que não signifique a mera reprodução do "modelo médico assistencial privatista", e a subordinação do "modelo sanitarista", ou seja, a chamada "inampização" do SUS.

Pelo contrário, levando-se em conta a existência de instrumentos financeiros, como o Piso Assistencial Básico (PAB fixo e variável), gerenciais e técnico-operacionais, a exemplo da Programação Pactuada Integrada (PPI), do Programa de Agentes Comunitários de Saúde (PACS), do PSF e do VIGISUS, que podem ser utilizados para a criação de uma proposta que aponta em outra direção, o município pode caminhar para a construção de um modelo fundamentado na Vigilância da Saúde.

A Figurá 1 sintetiza essa possibilidade de atuação do município, articulando, para cada um dos níveis de atenção, as distintas propostas que se encontram em debate na presente conjuntura.

Figura 1 Vigilância da Saúde: articulação entre intervençōes

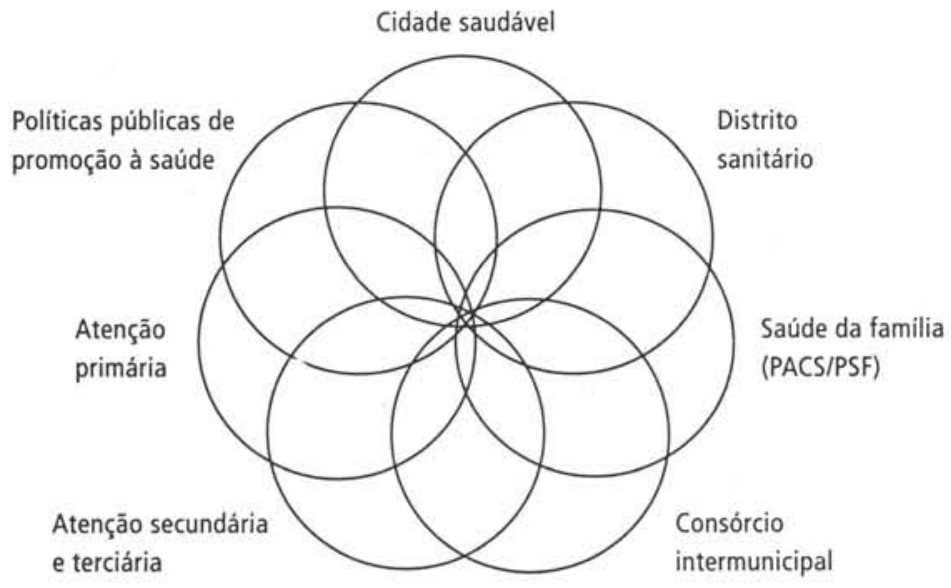




\section{Vigilância à Saúde e Vigilância da Saúde}

\section{A Vigilância no campo da Saúde Pública}

A incorporação da noção de risco e, especialmente, a busca de identificação dos fatores de risco envolvidos na determinação das doenças, não só as infectocontagiosas mas principalmente as crônico-degenerativas, que passam a ocupar um lugar predominante no perfil epidemiológico das populações em sociedades industriais, vêm provocando a modernização das estratégias de ação no campo da Saúde Pública. Essa modernização se dá tanto pela ampliação e diversificação do seu objeto quanto pela incorporação de novas técnicas e instrumentos de geração de informações e organização das intervenções sobre "danos", "indícios de danos", "riscos" e "condicionantes e determinantes" dos problemas de saúde (Paim, 1994).

Desse modo, além da ampliação do objeto dos "programas de controle" que tendem a ultrapassar o limite estreito das doenças infecciosas e parasitárias, e se dirigem a grupos populacionais expostos a riscos diferenciados de adoecer e morrer, - a exemplo dos programas de "saúde materno-infantil", "saúde do trabalhador", "saúde do idoso", etc., - se vem observando, ainda, notadamente a partir dos anos 70, a formulação e a implementação de propostas dirigidas à montagem de "sistemas de Vigilância Epidemiológica", cuja tradução operacional pretende ser uma ampla rede de unidades geradoras de dados que permitam a adoção de decisões e a execução de ações de investigação e de controle.

A institucionalização dos programas de erradicação e controle e a implantação da Vigilância, no Brasil, ao longo dos últimos noventa anos, implicou, do ponto de vista político-institucional, na organização centralizada (federal) de órgãos e departamentos responsáveis pelas campanhas e programas. Ao mesmo tempo, cristalizava-se uma distinção entre a Vigilância Epidemiológica, voltada para o controle de "casos" e "contatos", e a Vigilância Sanitária, voltada para o controle de "ambientes, produtos e serviços." Embora se possa considerar que, do ponto de vista técnico-operacional, especificidades justificam a existência dessas "vigilâncias", a primeira, a epidemiológica, obedecendo uma racionalidade técnico-sanitária fundada na clínica e na epidemiologia, e a segunda, obedecendo uma racionalidade político-jurídica, fundada nas normas que regulamentam a produção, a distribuição e o consumo de bens e serviços (Costa, 1998), não se justifica a sua institucionalização como órgãos separados, particularmente no âmbito municipal. Isto gerou, inclusive, a reflexão sobre os limites e possibilidades de "integração" institucional das "vigilâncias", debate ainda atual na medida em noção de risco e ação em Saúde Pública

Vigilância Epidemiológica e Vigilância Sanitária 
oferta organizada de serviços que se avance para a formulação e a implementação de um sistema de Vigilância da Saúde, como proposto em uma oficina de trabalho realizada no Congresso Brasileiro de Epidemiologia de 1995.

A fundamentação dessa proposta se baseia, de um lado, nos avanços conceituais, metodológicos e instrumentais no campo da Epidemiologia e, de outro, na análise do contexto político-institucional decorrente do processo de construção do SUS, especialmente no que se refere à descentralização das ações de Vigilância da Saúde para os municípios.

\section{As vertentes do debate sobre Vigilância da Saúde no Brasil}

Paim (1994) discute a possibilidade de análises mais abrangentes da situação de saúde conduzirem a propostas de reorganização dos serviços, com base em um diagrama (Figura 2) que ilustra o processo de transição para um novo modelo assistencial. Nesse modelo, a oferta organizada de serviços viria a suplantar as ações dirigidas ao atendimento da chamada "demanda espontânea", e as realizadas a partir da implantação dos chamados "programas especiais", dirigidos a grupos populacionais específicos. A "organização da oferta", ou "oferta programada", seria o espaço de articulação do enfoque epidemiológico, na medida em que a programação e a execução das ações e serviços deveriam partir da identificação dos problemas e necessidades da população, em territórios delimitados, a exemplo do que vinha ocorrendo em vários Distritos Sanitários em processo de implantação.

Figura 2 Diagrama de transição para os novos modelos assistenciais

$\begin{array}{lr}\text { Modelo } & \text { Novos modelos } \\ \text { anterior ao SUS } & \text { assistenciais }\end{array}$

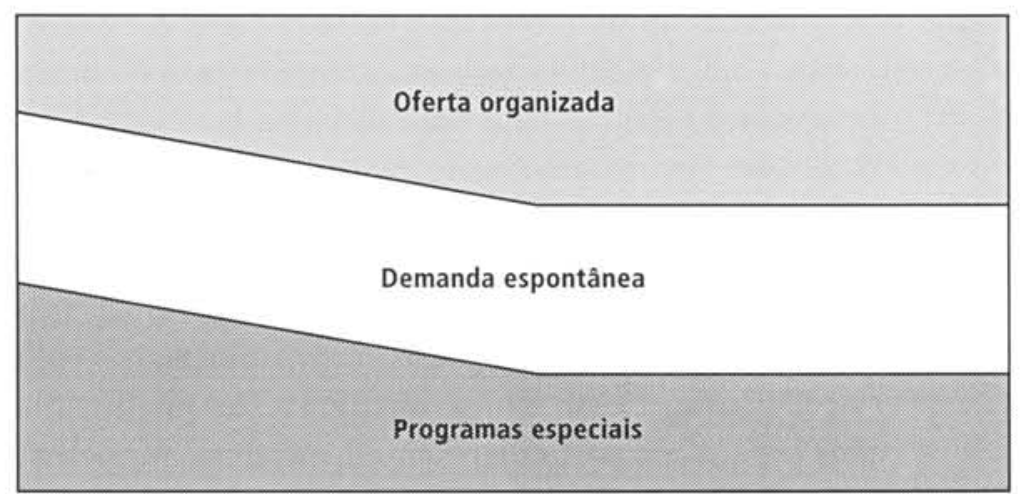


Já no III Congresso Brasileiro de Epidemiologia (1995) aparece a distinção entre uma concepção "ampla" e outra "restrita" de Vigilância da Saúde. A concepção "restrita" entende por Vigilância à Saúde, "um conjunto de ações voltadas para o conhecimento, a previsão, a prevenção e o enfrentamento continuado de problemas de saúde selecionados e relativos aos fatores e condições de risco, atuais e potenciais, e aos acidentes, incapacidades, doenças - incluindo as zoonoses, e outros agravos à saúde de uma população num território determinado."

Dá-se, portanto, uma ampliação da Vigilância Epidemiológica, com a incorporação da Vigilância Sanitária. Não se prevê, entretanto, a reorganização do conjunto das ações e serviços de atenção à saúde, inclusive a intervenção sobre determinantes sociais, de um lado, e a assistência médico-hospitalar, de outro.

Por seu turno, a concepção ampliada fundamentar-se-ia no diagrama da Figura 3, articulando os novos conceitos e métodos - gerados a partir de uma visão ampliada de saúde e dos modelos atuais de interpretação dos determinantes, riscos, agravos e danos - em um esquema operacional que resgata e amplia o modelo clássico da História Natural das Doenças; nesse esquema, se incorporam desde as ações sociais organizadas pelos distintos atores até as ações específicas de prevenção de riscos e agravos, bem como as de recuperação e reabilitação de doentes.

Portanto, no debate atual sobre a Vigilância da Saúde poderiam ser sintetizadas as seguintes vertentes:

a) Vigilância da Saúde como análise de situações de saúde. Ainda que ampliando e redefinindo o objeto de análise - situações de saúde de grupos populacionais definidos em função de suas condições de vida, esta acepção restringe o alcance da proposta ao monitoramento da situação de saúde, não incorporando as ações voltadas ao enfrentamento dos problemas. Do ponto de vista da prática epidemiológica em serviços, tem significado uma ampliação dos objetos de Vigilância Epidemiológica, que passam a abarcar não apenas as doenças transmissíveis, mas incorporam investigações e montagem de bancos de dados sobre outros agravos - como mortalidade infantil, mortalidade materna, doenças crônicas, acidentes e violência - como também aspectos relativos à organização e à produção dos serviços de saúde, e, assim, contribuem para um planejamento de saúde mais abrangente (Waldman, 1992).

b) Vigilância da Saúde como proposta de "integração" institucional entre a Vigilância Epidemiológica e a Vigilância Sanitária. Inicialmente restrita ao âmbito do processo de descentralização das ações para os órgãos estaduais (SES), essa vertente atualmente se insere no processo de municipalização. E se concretizou em várias das reformas administrativas monitoramento da situaçăo de saúde 
Figura 3 Diagrama de Vigilância da Saúde

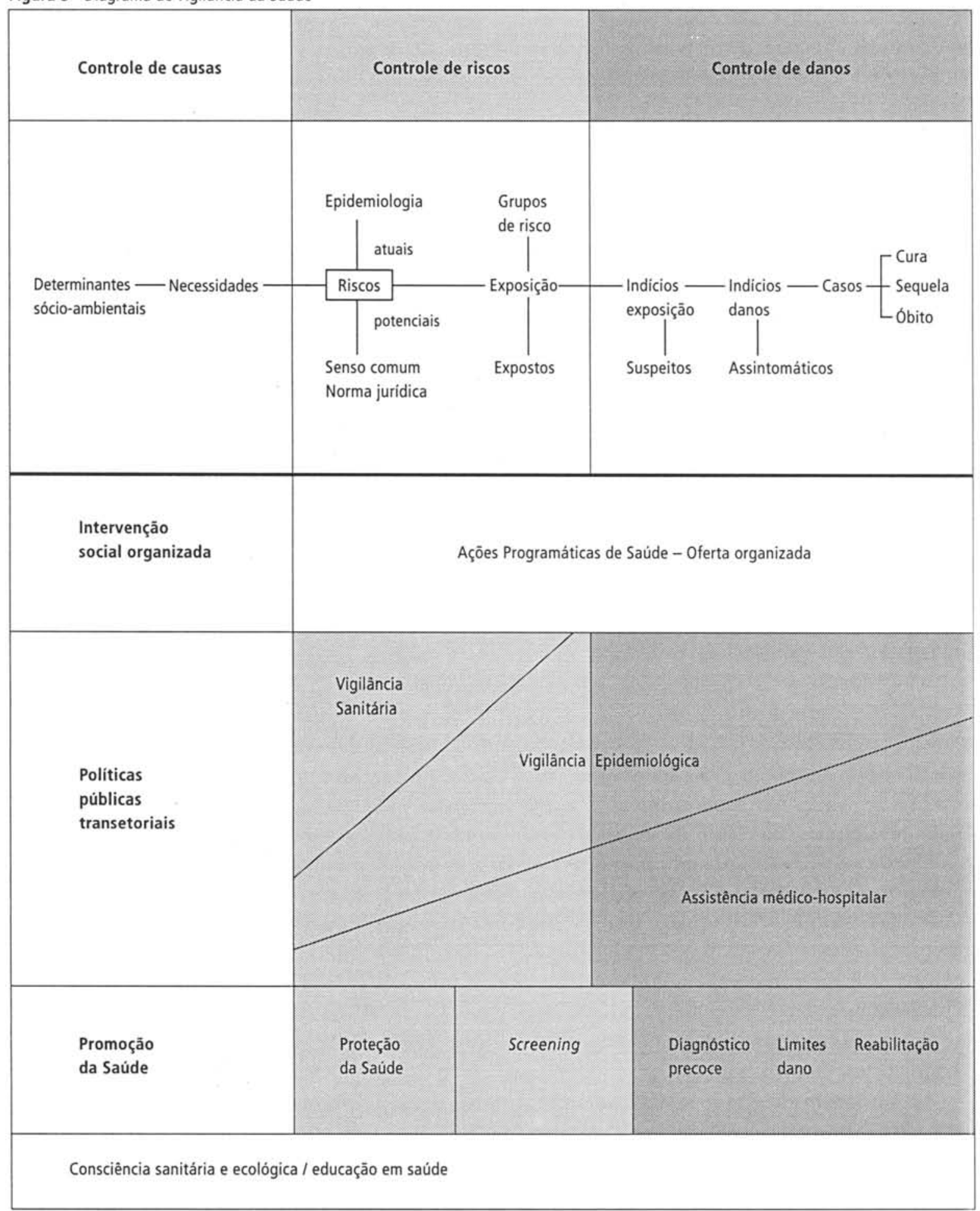


levadas a cabo pelas Secretarias Estaduais de Saúde na primeira metade dos anos 90, com a criação de Departamentos de Vigilância da Saúde.

c) Vigilância da Saúde como proposta de redefinição das práticas sanitárias. Há duas concepções dessa vertente, que enfatizam aspectos distintos:

- uma, privilegia a dimensão técnica, ao conceber a Vigilância da Saúde como um modelo assistencial alternativo, conformado por um conjunto de práticas sanitárias que encerram combinações tecnológicas distintas, destinadas a controlar determinantes, riscos e danos (Paim, 1994);

- uma reforça a dimensão gerencial, caracterizando a Vigilância da Saúde, como "uma prática que organiza processos de trabalho em saúde sob a forma de operações", para confrontar problemas de enfrentamento contínuo, num território delimitado (...) através de operações montadas segundo os problemas, nos seus diferentes períodos do processo saúdedoença (Mendes, 1993).

Comparando a Vigilância da Saúde com os modelos assistenciais vigentes (médico-assistencial e sanitarista, hegemônicos) constatam-se diferenças quanto a sujeitos, objeto, métodos e forma de organização dos processos de trabalho (Quadro 1). Enquanto o modelo médico-assistencial privilegia o médico, tomando como objeto a doença, em sua expressão individualizada, e utiliza como meios de trabalho os conhecimentos e tecnologias que permitem o diagnóstico e a terapêutica das diversas patologias, o modelo sanitarista tem como sujeitos os sanitaristas, cujo trabalho toma por objeto os modos de transmissão e fatores de risco das diversas doenças, segundo uma perspectiva epidemiológica, e utiliza um conjunto de meios que compõem a tecnologia sanitária (educação em saúde, saneamento, controle de vetores, imunização, etc.)

A Vigilância da Saúde, todavia, propõe a incorporação de novos sujeitos, extrapolando o conjunto de profissionais e trabalhadores de saúde, ao envolver a população organizada, o que corresponde à ampliação do objeto, que abarca, além das determinações clínicoepidemiológicas, no âmbito individual e coletivo, as determinações sociais que afetam os distintos grupos populacionais em função de suas condições de vida. Nessa perspectiva, a intervenção também extrapola o uso dos conhecimentos e tecnologias médico-sanitárias e inclui tecnologias de comunicação social que estimulam a mobilização, a organização e a atuação dos diversos grupos na promoção e na defesa das condições de vida e saúde.

As formas de organização dos processos de trabalho, em cada um desses modelos, são diversas. Do trabalho intensivo condensado na rede de prestação de serviços de saúde, cujo locus privilegiado, no modelo médico-assistencial, é o hospital, passa-se, no modelo sanitarista, às uni- criação dos

Departamentos de

Vigilância da Saúde

combinaçōes tecnológicas distintas $\mathrm{x}$ processos de trabalho sob a forma de operaçōes

ampliaçāo do objeto e do caráter da intervenção 
caracteristicas

de Vigilância da Saúde dades de saúde, a partir das quais se operacionalizam as campanhas, programas e ações das Vigilância Epidemiológica e Sanitária. A proposta de Vigilância da Saúde, entretanto, transcende os espaços institucionalizados do "sistema de serviços de saúde", se expande a outros setores e órgãos de ação governamental e não-governamental, e envolve uma trama complexa de entidades representativas dos interesses de diversos grupos sociais.

Em síntese, a Vigilância da Saúde apresenta sete características básicas: a) intervenção sobre problemas de saúde (danos, riscos e/ou determinantes); b) ênfase em problemas que requerem atenção e acompanhamento contínuos; c) operacionalização do conceito de risco; d) articulação de ações promocionais, preventivas e curativas; e) atuação intersetorial; f) ações sobre o território; g) intervenção sob forma de operações.

Quadro 1 Modelos assistenciais e Vigilância da Saúde

\begin{tabular}{|c|c|c|c|c|}
\hline Modelo & Sujeito & Objeto & $\begin{array}{l}\text { Meios de } \\
\text { trabalho }\end{array}$ & $\begin{array}{l}\text { Formas de } \\
\text { organização }\end{array}$ \\
\hline Modelo & Médico & Doença (patologia e outras) & Tecnologia & Rede de serviços de saúde \\
\hline $\begin{array}{l}\text { médico- } \\
\text { assistencial } \\
\text { privatista }\end{array}$ & $\begin{array}{l}\text { - especialização } \\
\text { - complementariedade } \\
\text { (paramédicos) }\end{array}$ & Doentes (clinica e cirurgia) & $\begin{array}{l}\text { médica } \\
\text { (individuo) }\end{array}$ & Hospital \\
\hline
\end{tabular}

\begin{tabular}{|c|c|c|c|c|}
\hline $\begin{array}{l}\text { Modelo } \\
\text { sanitarista }\end{array}$ & $\begin{array}{l}\text { Sanitarista } \\
\text { - auxiliares }\end{array}$ & $\begin{array}{l}\text { Modos de transmissão } \\
\text { Fatores de risco }\end{array}$ & $\begin{array}{l}\text { Tecnologia } \\
\text { sanitária }\end{array}$ & $\begin{array}{l}\text { Campanhas sanitárias } \\
\text { Programas especiais } \\
\text { Sistemas de Vigilância } \\
\text { Epidemiológica e Sanitária }\end{array}$ \\
\hline
\end{tabular}

$\begin{array}{llll}\begin{array}{l}\text { Vigilância } \\ \text { da Saúde }\end{array} & \begin{array}{l}\text { Equipe de saúde } \\ \text { População (cidadãos) }\end{array} & \begin{array}{l}\text { Danos, riscos, necessidades } \\ \text { e determinantes dos modos } \\ \text { de vida e saúde (condiçōes } \\ \text { de vida e trabalho) }\end{array} & \begin{array}{l}\text { Tecnologias de } \\ \text { comunicação social, } \\ \text { de planejamento } \\ \text { e programação } \\ \text { local situacional } \\ \end{array} \\ & & \begin{array}{l}\text { e tecnologias } \\ \text { médico-sanitárias }\end{array}\end{array}$

Políticas públicas saudáveis

- Açōes intersetoriais

- Intervenções especificas (promoçāo, prevençāo e recuperação)

- Operaçōes sobre problemas e grupos populacionais 


\section{A operacionalização da Vigilância da Saúde no município}

No momento atual, a elaboração de propostas de operacionalização da Vigilância toma como eixo central o processo de municipalização. Considerando os incentivos financeiros previstos na NOB 96, as ações de capacitação de pessoal e de cooperação técnica, previstas no VIGISUS, a possibilidade de assessoria por parte das Secretarias Estaduais de Saúde e de instituições acadêmicas, o município vê-se diante do desafio de reorientar o conjunto de ações e serviços desenvolvidos no sistema municipal de saúde. Quais sejam: a) assumir e consolidar a Vigilância Epidemiológica; b) assumir e consolidar a Vigilância Sanitária; c) assumir e implementar os programas de saúde da família; d) reorganizar o perfil de oferta das unidades básicas, considerando os programas especiais e o perfil epidemiológico da população; e) articular a atenção de média e alta complexidades, fortalecendo a rede pública e renegociando a compra de serviços ao setor privado; f) redefinir as assistências laboratorial e farmacêutica.

Adotar a concepção ampliada de Vigilância da Saúde, visando a transformação do modelo de atenção à saúde ao nível municipal, implica, em primeiro lugar, avançar no processo de municipalização da gestão do sistema e da gerência das unidades de saúde localizadas no território dos municípios. Em segundo lugar, implica investir na articulação intersetorial, na reorganização da atenção primária (oferta organizada e ações de promoção da saúde e prevenção de riscos e agravos, partindo dos territórios da "saúde da família" aos territórios distrital e municipal) e no fortalecimento do controle social sobre a gestão do sistema de saúde.

O ponto de partida para o desencadeamento do processo de planejamento da Vigilância da Saúde é a territorialização do sistema municipal de saúde. Isto é, - o reconhecimento e o esquadrinhamento do território do município segundo a lógica das relações entre condições de vida, saúde e acesso às ações e serviços de saúde. Isto implica um processo de coleta e sistematização de dados demográficos, socioeconômicos, político-culturais, epidemiológicos e sanitários que, posteriormente, devem ser interpretados segundo o mapa básico e os mapas temáticos do município.

Um mapa básico contem a delimitação territorial do município, com o desenho da configuração urbano-rural. Ou seja, contem a delimitação dos distritos, bairros, ruas, contempla o adensamento demográfico da população. Os mapas temáticos implicam, em primeiro lugar, a localização espacial dos serviços de saúde e outros equipamentos sociais, como creches, escolas, igrejas, etc, e a delimitação das vias de 
definição de prioridades

tomada de decisões

\author{
reorganização de \\ equipes de trabalho \\ e controle gerencial \\ e social
}

acesso da população aos serviços; essas medidas fornecem uma idéia dos fluxos de demanda às diversas unidades de saúde do município.

Em segundo lugar, deve-se caracterizar os diversos grupos populacionais dos municípios, segundo suas condições de vida, o que permitirá a justaposição do mapa básico aos mapas temáticos dos serviços de saúde e o das condições de vida. Finalmente, é necessário fazer a distribuição espacial dos principais problemas de saúde, identificados em função de informações epidemiológicas extraídas de bancos de dados oficiais, ou obtidas através de "estimativa rápida", com "informanteschave", e cruzar estas informações com os mapas elaborados anteriormente.

O propósito fundamental desse processo de territorialização é permitir a definição de prioridades, em termos de problemas e grupos, a mais aproximada possível, o que se refletirá na definição das ações mais adequadas, de acordo com a natureza dos problemas identificados, bem como na concentração de intervenções sobre grupos priorizados. Querse, conseqüentemente, conseguir um maior impacto positivo sobre os níveis de saúde e as condições de vida. Uma vez que se conte com a territorialização do município, segundo as condições de vida e saúde, enquanto parte da análise da situação de saúde, é possível dar seguimento ao processo de planejamento e programação local; esse processo, porém, não se esgota na mera racionalização da oferta de serviços ambulatoriais e hospitalares, tal como ocorreu na maioria dos Estados durante o primeiro movimento da Programação Pactuada Integrada (PPI).

O município pode construir uma "árvore de problemas", ou um "fluxograma situacional", para sistematizar as informações acerca dos problemas de saúde, e subsidiar, assim, um processo de tomada de decisões com relação ao "que fazer" para enfrentá-los. Essas decisões contemplam uma "árvore de objetivos", da qual derivam as ações a serem realizadas nos territórios considerados segundo uma perspectiva intersetorial.

O conjunto das ações e serviços definidos para o enfrentamento dos problemas selecionados constituem as operações a serem implementadas, segundo uma lógica que privilegie não a organização de estruturas burocráticas para administrar os recursos humanos e materiais envolvidos, mas sim a perspectiva de flexibilização gerencial (por projetos). Essa última, implica a reorganização de equipes de trabalho e o gerenciamento descentralizado e modular, e privilegia o controle gerencial e social do processo de implementação das ações. Do ponto de vista do conteúdo, as operações definidas no âmbito do município poderão incorporar desde ações políticas, de mobilização social, no âmbito de organizações governamentais e não-governamentais, até ações de sa- 
úde propriamente ditas, envolvendo a educação sanitária e a comunicação social, dirigidas a grupos específicos, em função da distribuição social dos problemas de saúde, ações de Vigilância Epidemiológica, Sanitária e nutricional, e até serviços de assistência direta a pessoas, ao nível ambulatorial e hospitalar.

Na perspectiva técnica da implementação da Vigilância da Saúde, a metodologia de planejamento e programação poderia ser aplicada em distintos momentos, na seguinte seqüência lógica: análise da situação de saúde; desenho de situação-objetivo; desenho das estratégias; programação, acompanhamento e avaliação.

\section{Comentários finais}

Planejar e programar o desenvolvimento da Vigilância da Saúde em um território específico, exige um conhecimento detalhado das condições de vida e trabalho das pessoas que residem no território, bem como das formas de organização e de atuação dos diversos órgãos governamentais e não-governamentais, para que se possa ter "visão estratégica", isto é, clareza sobre o que é necessário, e possível, fazer. Exige também uma disponibilidade e um interesse em desenvolver uma ação comunicativa, isto é, em participar de um diálogo permanente com os representantes desses órgãos, com os representantes dos grupos sociais, e com as pessoas, de um modo geral, buscando envolvê-las em um trabalho coletivo.

A operacionalização dessas idéias supõe identificar novas maneiras de pensar o processo de trabalho em saúde. Independentemente das diversas concepções de Vigilância, é possível destacar a preocupação com o impacto sobre o estado de saúde da população e a situação epidemiológica. Isto significa uma possibilidade de reconceitualização do objeto das práticas de saúde. E, por conseguinte, a formulação de indagações sobre a pertinência, a consistência ou a eficácia dos meios de trabalho e do trabalho propriamente dito, indagações a serem utilizadas para a apreensão e/ou transformação desse objeto. 


\section{Referências bibliográficas}

COSTA, E. A., 1998. Vigilância Sanitária: defesa e proteção da saúde. São Paulo: Tese de doutoramento - Faculdade de Saúde Pública - USP, p. 327.

MENDES, E. V., 1993. Planejamento e programação local da Vigilância da Saúde no Distrito Sanitário. Série Desenvolvimento de Serviços de Saúde, n² 13, Brasília: OPS,

PAIM, J. S., 1994. A Reforma Sanitária e os Modelos Assistenciais. In: ROUQUAYROL, M. Z. Epidemiologia \& Saúde, São Paulo: MEDSI, p. 455-466.

TEIXEIRA, C. F., 1993. Planejamento e programação situacional em distritos sanitários. In: MENDES, E.V. Distrito Sanitário: o processo social de mudança das práticas sanitárias do Sistema Único de Saúde. São Paulo: HUCITEC/Abrasco, p. 237-265.

WALDMAN, E. A., 1992. As concepçōes de vigilância como instrumento de saúde pública e a implantação do SUS. In: Seminário Nacional de Vigilância Epidemiológica. Anais. Brasília: MS.FNS. CENEPI, p. 45-51. 


\section{Organização e funções do Estado}

\section{Conteúdo}

Estruturação das sociedades modernas. Conceitos básicos para a compreensão das sociedades complexas. O Estado, direitos e democracia na modernidade: a coletivização e o direito à saúde. As Normas Operacionais Básicas: histórico, responsabilidades e requisitos. Organização jurídica da administração pública: Estado Constitucional, Estado de Direito e Estado Democrático de Direito; controle social; descentralização; Sistema Nacional de Proteção ao Consumidor.

A leitura deve permitir:

- Compreender os conceitos de Estado, estrutura social, sistema econômico, relações sociais de produção, ideologia e direitos, e sua aplicação na sociedade brasileira, com vistas a contextualizar o papel da Vigilância como política pública e a compreendê-la na sua dimensão ética e cidadã.

- Entender o caráter político da ação da cidadania, vinculando-a às noções de igualdade e de direitos, e à construção da democracia.

- Valorizar a participação social no desempenho das ações de Vigilância, reconhecendo as múltiplas possibilidades de articulação da mesma com os diferentes órgãos e atores sociais, com ênfase no movimento de defesa do consumidor.

- Conhecer as Normas Operacionais Básicas do Ministério da Saúde, seu papel no financiamento das ações de saúde coletiva, bem como seus alcance e limitações como instrumento de descentralização e de repartição do poder.

- Descrever os principais instrumentos jurídicos de proteção aos direitos individuais e coletivos, assim como os mecanismos de partici- 
pação direta na administração pública, em particular os conselhos de saúde, as conferências de saúde e o código de defesa do consumidor.

- Identificar a natureza política e jurídica da repartição constitucional de competências entre as três esferas de governo, na proteção e na defesa da saúde, assim como as responsabilidades atribuídas aos municípios pela lei orgânica. Compreender o potencial de ação sustentado pela legislação dos poderes constitucionais da República quanto, à garantia do direito à saúde. 


\section{Complexidade da ordem social contemporânea e redefinição da responsabilidade pública}

Regina Cele de A. Bodstein

\section{Caracterização das sociedades complexas}

O ponto de partida da análise vem da concepção moderna de sociedade, que emerge na Europa ocidental durante os séculos XVII e XVIII. Tal concepção é inseparável, por um lado, da crescente divisão do trabalho e, por outro, da representação do indivíduo como princípio éticomoral, auto-instituinte da vida sócio-cultural. Esses dois conjuntos de transformação, um vinculado à ordem econômica, e outro a valores culturais e simbólicos, permitem compreender os diversos significados da nova sociedade em gestação.

O primeiro aspecto diz respeito à chamada Revolução Industrial que instaura, através da introdução da ciência e da técnica no universo da produção, acentuadas divisão e especialização do trabalho. Como conseqüência, o mundo do trabalho se transforma inteiramente, provocando um inédito crescimento da produção, do mercado e do consumo. Nessa perspectiva, podemos definir uma sociedade complexa como uma sociedade em acelerado processo de industrialização.

O outro aspecto, mais crucial, ainda que menos visível, refere-se a ser a complexidade dessa sociedade representada pelo aparecimento de um conjunto de valores ideológicos e s.mbólicos que transforma o indivíduo, em sua singularidade, no centro aesta sociedade. Isto é, estamos diante de uma configuração social em que se incentiva e se espera que os indivíduos sejam tomados, um a um, como iguais e soberanos. E, nessa condição básica de igualdade, possam assumir novas posições e novos deveres no universo do trabalho. Os indivíduos passam a ser representados como "trabalhadores livres", na medida em que aparecem libertos das antigas e rígidas posiçōes da ordem feudal. Mas, sobre-
Revolução Industrial 
individualização

e diferenciação

liberdade individual

igualdade diante da lei tudo, porque, simbolicamente, se vêem livres e iguais em direitos, longe, portanto, das antigas crenças, hierarquias e valores tradicionais.

Coloca-se, portanto, no centro da discussão desse período, a ruptura com os vínculos de dependência social que subordinavam os indivíduos a uma ordem hierárquica de funções e papéis sociais, rígidos e estabelecidos pela condição de nascimento, marca indelével da ordem feudal, até então dominante. A transformação histórica da modernidade vem no bojo da recriação contínua de novos valores e de novos direitos: os indivíduos, cada um em sua singularidade, têm a liberdade de ir e vir e de assumir qualquer contrato de trabalho. Podem ousar crer, querer e agir conforme suas preferências e valores. Em termos sociológicos, entendeu-se a emergência da modernidade como um processo de individualização e diferenciação.

"A partir da crescente diferenciação da sociedade e com a conseqüente individualização dos indivíduos, esse caráter diferenciado de uma pessoa em relação a todas as demais torna-se algo que ocupa um lugar particularmente elevado na escala social de valores. Nessas sociedades, torna-se um ideal pessoal de jovens e adultos diferir dos semelhantes de um modo ou de outro, distinguir-se - em suma, ser diferente" (Elias, 1994:118).

No bojo desse longo processo, o direito à diferença, à singularidade, à recriação de identidades e papéis e, portanto, a ampliação constante de direitos, transforma-se em um dos mais altos valores da afirmação da liberdade individual, fundamento da nova complexidade da ordem social e da procura de novas instituições políticas. Nas sociedades que se modernizam, esse fenômeno de diferenciação e afirmação de valores individuais adquire centralidade, impulsionando um conjunto enorme de transformações socioculturais.

A experiência da cidadania, e seus desdobramentos no direito a ter direitos, parece ser a chave para a compreensão do principal problema social contemporâneo: a inclusão dos indivíduos em um sistema de valores comuns que lhes garanta, apesar de toda diferença entre eles, a igualdade básica de todos diante da lei, e, assim, um nível mínimo de consenso e legitimidade.

A modernidade estabelece uma inversão e uma descontinuidade com todo o pensamento político antigo, instalando momentos de ruptura e de cisão. E traz para o centro do debate os direitos humanos, que o sentido da revolução francesa tão bem explicita: igualdade, liberdade e fraternidade. A modernidade inaugura um sentimento de perplexidade e de dúvida (que a ciência moderna traduz) diante do mundo e dos fenômenos humanos, já que o significado da história e da sociedade não se encontra mais no legado da tradição (Arendt, 1971:47). O despertar 
para a modernidade se dá concomitantemente ao estabelecimento de um novo fundamento, a busca de um princípio legitimador da nova ordem social em construção.

É no contexto histórico de transição para uma sociedade em via de modernização que o trabalho deixa de ser considerado um fenômeno meramente natural, privado e necessário, porém vergonhoso. E passa a ser a capacidade criativa mais especificamente humana e nobre, a gerar, em tese, toda a riqueza e todo o desenvolvimento sociocultural, caminho possível de superação da pobreza e das desigualdades sociais.

As discussões em torno da sobrevivência e da desigualdade, centrais para o pensamento político moderno e para a chamada economia política nascente, emergem nesse contexto. Assim, uma das transformações mais fantásticas da modernidade, e uma das peculiaridades da sociedade ocidental do período, é a valorização do trabalho e de sua crescente divisão e especialização, a ponto de torná-lo o centro mesmo da vida social. O trabalho passa a ser representado como uma atividade produtiva, emancipadora do homem, capaz de libertá-lo da miséria e da pobreza.

Parece fácil entender que a valorização do homem livre, produtivo e empreendedor é uma conseqüência da valorização do trabalho como eixo diferenciador/integrador das novas classes sociais em formação. E como atividade em torno da qual ocorre a radical distinção entre a classe trabalhadora, privada dos meios de produção, e a dos capitalistas, aqueles que possuem e concentram os meios de produção. Paradoxalmente, se o trabalho torna-se fonte de riqueza e liberdade, constitui, ainda, um espaço de exploração e de dominação de uma minoria sobre uma maioria, maioria para a qual a atividade produtiva representa um pesado fardo.

De qualquer forma, é inegável que a crescente divisão do trabalho demonstra os benefícios da especialização e da busca de maior competência técnica, bem como o mérito e o potencial transformador da liberdade individual e da iniciativa privada. O espaço da liberdade individual, do mercado e do mundo privado, baseia-se, paradoxalmente, em um longo processo de redefinição do universo da produção e do trabalho, em que cadeias de interdependência se multiplicam de forma incontrolável. Isto é, junto à crescente divisão social do trabalho e da especialização burocrática de tarefas e, portanto, da supervalorização do trabalho e do mundo privado - campo fértil para o florescimento do individualismo -, ocorre a formação de cadeias cada vez mais complexas de dependência entre os indivíduos, no universo do trabalho, cadeias que, desde então, se espalham para o resto da sociedade.

Locke, um dos mais vigorosos pensadores liberais do século XVII, sintetiza, com bastante clareza, a concepção da sociedade nascente a trabalho

\section{desigualdade}

\author{
distinção entre \\ a classe trabalhadora \\ e os capitalistas
}


sociedade individualista

A construção de uma utopia social baseada na ideologia individualista, na afirmação política do cidadão livre e titular de direitos, constitui-se em um dos principais aspectos da transformação da sociedade tradicional em uma sociedade contemporânea e moderna. A garantia, isto é, a prerrogativa de cada indivíduo poder reivindicar, sempre que desejar, a igualdade jurídica, a condição de cidadão e de sujeito político, e de poder buscar, por caminhos múltiplos e incertos, a transformação do 
status quo, sem dúvida se constituiu na principal alavanca ideológica da modernidade e em seu principal fundamento político.

A concepção individualista desdobra-se em um conjunto inteiramente novo de categorias político-sociais: liberdade, igualdade e direitos individuais. E indica, acima de tudo, uma cisão com a representação das relações políticas e dos valores culturais até então dominantes. Devemos lembrar que, na antiga sociedade feudal, a desigualdade de status e a condição social eram afirmadas em lei. O ponto de partida é, pois, a caraterização do homem livre e empreendedor e, portanto, produtor/trabalhador autônomo. Trata-se de pensar a dinâmica de transformação da categoria de trabalhador livre para a de homem livre, desprendido de um sistema hierárquico secular, baseado em vínculos feudais de lealdade e de obediência. Esse processo permite a entrada triunfal do novo homem livre e produtivo no centro das preocupações sociopolíticas da modernidade.

Apesar da multiplicidade de posições e funções distintas no processo produtivo, essa sociedade moderna, como a analisa Hannah Arendt, é igualitária no sentido de que se espera alguma atividade produtiva de todos os homens. O efeito mais notável e paradoxal desse processo é, na sociedade moderna e complexa, a ascensão do trabalhador ao universo público e aos direitos de cidadania. A capacidade de exercer qualquer trabalho produtivo será, desde então, critério de acesso ao status de cidadão.

$\mathrm{Na}$ brilhante análise do longo processo civilizador, ou seja, das precondições para o surgimento da sociedade moderna, Norbert Elias esmiuça as exigências impostas à conduta dos indivíduos. E traz à tona a discussão entre princípios de igualdade e de diferenciação social. Elias revela ter sido a tendência fundamental do processo civilizador, em toda a parte, a de promoção de um autocontrole individual, isto é, de um certo adiamento da satisfação de impulsos e desejos, em prol de relações sociais mais previsíveis e seguras. Este processo, deflagrado primeiro no comportamento das classes superiores ocidentais, vai paulatinamente difundir-se a todos os estratos, diminuindo os grandes contrastes de comportamento entre os diferentes grupos sociais.

"Essa redução dos contrastes na sociedade e nos indivíduos, essa mistura peculiar de padrões de conduta que derivam de níveis sociais inicialmente muito diferentes, são altamente característicos da sociedade ocidental. E constitui uma das peculiaridades mais importantes do "processo civilizador" (Elias, 1993:211).

Por outro lado, é importante perceber que a crescente divisão social do trabalho se baseia no incentivo ao desenvolvimento das aptidões e vocações distintas, justifica a especialização do trabalhador, isto é, sua liberdade, igualdade e direitos individuais

autocontrole individual

desenvolvimento das aptidões e vocações 
conflito e confrontação

teoria do direito natural

contrato diferenciação. O indivíduo produtivo, o novo cidadão que se quer forjar, é representado, na sua singularidade, como o mostramos, a partir de uma condição inicial de igualdade: igualdade de todos perante a lei. Esse artifício lógico permitiu, por um lado, a harmonia entre os princípios da igualdade e da diferenciação e, por outro, a livre expressão e a reivindicação de direitos. O conflito e a confrontação marcam essa nova ordem social, que freqüentemente nega, ou impede, aos cidadãos, a igualdade nos direitos, o livre desenvolvimento de suas potencialidades e a capacidade de ser diferente, se assim o desejarem.

Desencadeando a procura de um novo princípio legitimador da ordem social ou de um novo fundamento para o poder, surge a moderna "teoria do direito natural." Segundo Dumont, "... os princípios fundamentais da constituição do Estado (e da sociedade) devem ser extraídos, ou deduzidos, das propriedades e qualidades inerentes no homem, considerado como um ser autônomo, independentemente de todo e qualquer vínculo social ou político" (Dumont, 1993:87).

A concepção do homem livre ocupa lugar central na ideologia individualista da sociedade, marca registrada do pensamento filosófico europeu a partir do século XVII. Como o sintetiza Dumont, o problema desse pensamento filosófico está em exprimir a unidade do grupo social e político e em estabelecer, a partir de indivíduos isolados e diferenciados, a sociedade e o Estado (Dumont, 1993:90). O fator que explica o consenso e o estabelecimento de novos vínculos sociais é o contrato, base do Estado democrático moderno. Da idéia de contrato nasce a idéia de que os indivíduos abrem mão da vontade própria para transferí-la ao soberano, em troca da liberdade civil, e passam a desfrutar, então, da existência em sociedade, agora sob a proteção do Estado de Direito.

Os critérios definidores da cidadania são, doravante, atributos e direitos naturais, que todos possuem, pelo nascimento. Se, de fato, não podem desfrutá-los, é legítimo reivindicá-los e denunciar a distância entre norma (lei) e fato. É exatamente a concepção do direito natural, ou da doutrina dos direitos humanos, que constitui a pedra angular do pensamento social e da teoria política moderna.

Como o mostra Dumont, o direito natural moderno está referido a indivíduos, "homens que se bastam a si mesmos enquanto feitos à imagem de Deus e enquanto depositários da razão" (Dumont, 1993:87). Trata-se de perceber que a força do projeto de modernização vem do fato de se considerar o sujeito/indivíduo/cidadão como centro e princípio último da sociedade e, portanto, da afirmação do direito de cada um, individualmente, criar, com liberdade, sua própria identidade. Assim, o individualismo não necessariamente deságua na ausência de uma esfera pública e na representação do social como um conjunto desarticula- 
do de indivíduos. A experiência da cidadania plena, como veremos adiante, representa medida de igualdade jurídica e possibilidade de reafirmação, tanto de novos vínculos como também de novas formas de solidariedade social.

O princípio da cidadania, eixo estruturador da nova sociedade, provoca, desde então, uma profunda transformação na representação da ordem social, e questiona a desigualdade e todas as formas de injustiça social "...a concepção do homem como indivíduo implica o reconhecimento de uma ampla liberdade de escolha. Alguns valores em vez de emanarem da sociedade, serão determinados pelo indivíduo para seu próprio uso (...), o indivíduo como valor (social) exige que a sociedade lhe delegue uma parte de sua capacidade de fixar os valores. A liberdade de consciência é o exemplo típico" (Dumont, 1993:269).

\section{Democracia e Estado de direito}

A rejeição da hierarquia e o movimento de reivindicação igualitária constituem o conjunto de valores mais poderoso e atuante dentro da ideologia moderna. É a grande força a sustentar os movimentos revolucionários que sacudiram a Europa a partir do século XVII, iniciados na Inglaterra, e cuja culminância é a Revolução Francesa, no final do século XVIII. A experiência da modernidade está intrinsecamente associada à própria idéia de utopia e libertação social, de uma sociedade em busca da justiça, igualdade e liberdade. Liberdade entendida para além de sua forma negativa - simples libertação da miséria e da opressão, mas como uma forma positiva que oferece a possibilidade de participação no espaço público e nos assuntos políticos.

Os princípios igualitários, universalizantes e homogeneizadores, longe de se vincularem a uma sociedade mais estável, equilibrada e previsível, paradoxalmente, colocam a sociedade moderna sob o risco do conflito, da mudança e da revolução. O indivíduo, da mesma forma paradoxal, parece prestes a se perder na impessoalidade das leis e dos códigos, sem vínculos sociais definidos e estáveis. O status de igualdade civil deve ser reinventado pois também está ameaçado. A universalidade das leis é sempre reivindicada pelos estratos sociais até então excluídos dos benefícios da cidadania. Ao mesmo tempo recriam-se, de acordo com as práticas sociais vigentes, novas formas de diferenciação de funções e de papéis sociais, e nascem, no mesmo movimento, novas formas de solidariedade e de exclusão social.

Assim, o dilema da sociedade moderna é que a livre e radical expressão das individualidades deixa em aberto, contraditoriamente, cidadania

reivindicação igualitária

dilema da sociedade

moderna 
fragmentação

Estado de Direito tanto a possibilidade de maior anomia ${ }^{1}$ e exclusão social, quanto, ao contrário, o fortalecimento de uma nova forma de vida ética, exercida através das diversas organizações da sociedade civil, funcionando como canais de interlocução com o Estado.

O fundamental para o entendimento da modernidade vem do fato de ser a fragmentação do mundo social - a radicalização da autonomia e da liberdade individuais -, um risco permanente. Mas, o mundo social pode, e é freqüentemente recomposto em todos os espaços onde se exercem plenamente os direitos, e se resgatam, para a sociedade civil novas formas e lugares de convivência democrática.

O chamado Estado de Direito, o pressuposto jurídico do Estado Democrático Moderno (Bobbio, 1987:20), é que irá estabelecer um princípio legitimador e pacificador dos conflitos sociais. Para que exista, de fato, o estado constitucional moderno, é preciso que sejam garantidas algumas precondições: os direitos fundamentais, a igualdade dos direitos, a igualdade perante a lei, a liberdade de opinião, de reunião, de informação, etc (Bobbio, 1987:20).

As leis civis e os princípios constitucionais do Estado de Direito, introduzem, dessa forma, a garantia da igualdade jurídica. A igualdade, assim, não é definida como um fato histórico, anulando toda a diferença entre os indivíduos e, muito menos, acabando com a divisão entre ricos e pobres. O progresso rumo à igualdade e à justiça social, princípios que a sociedade democrática incentiva, dependerá de uma série de conflitos e de lutas, que visam derrubar barreiras e privilégios a separarem superiores e inferiores, na escala social. Cabe a cada sociedade, segundo seus padrões e valores culturais, definir o nível e o limite de acumulação de riqueza e de propriedade que melhor lhe convém. Não se deve confundir igualdade jurídica com a igualdade real entre os indivíduos. Trata-se, no caso das sociedades modernas, de estabelecer o princípio da igualdade jurídica, base e fundamento último das sociedades democráticas e pluralistas.

A igualdade de direitos deve ser associada, como vimos, ao fim da rígida estratificação social, da exclusão e da discriminação vigentes na antiga ordem feudal. Essa igualdade está, sem dúvida, na origem do conceito moderno da cidadania, referido ao usufruto de direitos iguais, introduzido no cenário político do Ocidente a partir da Revolução Francesa. A igualdade, como princípio estruturador da vida social, é um dos aspectos mais polêmicos da cidadania moderna, e do próprio significado substancial da democracia.

\footnotetext{
1 A noção de anomia diz respeito à ausência de leis, normas ou regras sociais.
} 
Cidadania e democracia aparecem como processos articulados no cenário político da múdernidade, e convivem em total harmonia, pois ambas se referem ao processo de institucionalização da igualdade. Como nos mostra Bobbio, a igualdade dos direitos compreende a igualdade naqueles direitos fundamentais enumerados numa constituição, a serem gozados por todos os cidadãos, sem discriminação, aqueles direitos diante dos quais todos os cidadãos são iguais (Bobbio, 1988:41).

Porém, o medo atávico das classes dirigentes, diante da possibilidade de extensão e aprofundamento das condições reais ou materiais de igualdade (democracia no seu sentido substancial) - e a conseqüente abolição de privilégios - alimenta uma permanente tensão. Nesse sentido, a extensão dos direitos modernos suscitou, historicamente, as mais violentas reações e contestações.

A própria consolidação da democracia, compreendendo a extensão dos direitos políticos, sofreu a mais ferrenha oposição, na medida em que representou o principal mecanismo de defesa dos direitos de liberdade e de todos os valores liberais. Lefort (1991), um dos mais brilhantes filósofos políticos da atualidade, revela-nos que o paradoxo da democracia é exatamente ter permitido a constituição de novos personagens e atores na arena pública. O autor mostra que o Estado Liberal, guardião das liberdades civis, na prática assegurou a proteção dos interesses de uma minoria dominante. Essa realidade só foi contestada pela luta das massas, mobilizadas quer pela ampliação, quer pela criação de novos direitos (Lefort,1991:39). Daí não ser conveniente menosprezar o poder ambíguo, mas ao mesmo tempo inovador, da democracia que, bem ou mal, abre espaço para a constituição e renovação dos atores políticos e dos temas que compõem a agenda pública. Mais do que isso, foi somente através da institucionalização da democracia que todas formas de opressão, tirania, desigualdade extrema e injustiça social puderam ser denunciadas.

Para Lefort, os direitos do homem e a "revolução democrática" marcam uma mutação fundamental no pensamento político, " minha convicção continua sendo a de que só teremos alguma oportunidade de apreciar o desenvolvimento da democracia e as oportunidades para a liberdade com a condição de reconhecer na instituição dos direitos do homem os sinais da emergência de um novo tipo de legitimidade e de um espaço público no qual os indivíduos são tanto produtos quanto instigadores; com a condição de reconhecer, simultaneamente, que esse espaço só poderia ser devorado pelo Estado a custo de uma violenta mutação que daria nascimento a uma nova forma de sociedade" (Lefort, 1991:47).

Trata-se de pensar o Estado, ou o poder político, em sua função de viabilizar e proteger os direitos fundamentais dos indivíduos e de todos

cidadania e democracia

reações e contestações

paradoxo da democracia

o Estado na proteção dos direitos dos individuos 
espaço público ampliado

reinvenção dos direitos os projetos políticos de emancipação humana. É necessário considerar que a democracia moderna só existe quando ocorre o reconhecimento dos direitos básicos de cidadania e, portanto, um espaço público ampliado. Assim, liberdade política e renovação e ampliação dos direitos são indissociáveis. E o século XX apresenta vários casos de sociedades que, ao abolirem ou restringirem a liberdade política, acabaram por sufocar os direitos humanos. Quando o Estado restringe o direito de reunião, de expressão e de voto, acaba também por impedir o exercício dos demais direitos, na medida em que impede que interesses diversos, e opostos, manifestem-se de modo autônomo. Assim, o Estado democrático moderno continua sendo a mais poderosa salvaguarda dos direitos dos cidadãos contra os regimes totalitários.

Dessa forma, uma defesa da democracia compreende também uma defesa dos direitos fundamentais do homem, se abordados na sua radicalidade: como questionamento contínuo da ordem social estabelecida. Daí a democracia ser uma invenção e os direitos implicarem sempre a possibilidade de novos direitos. Os direitos do homem, para além de qualquer crítica em torno da limitação de seu exercício, certamente se constituem em formidável inovação histórica, e constituem, até o momento, o caminho mais fértil de transformação e democratização da ordem social.

Outro ponto fundamental, resgatado por Lefort, está centrado na vinculação dos direitos dos seus titulares, ou seja, dos sujeitos e atores sociais concretos. A esse respeito ele declara, "a compreensão democrática do direito implica a afirmação de uma fala - individual ou coletiva -, que sem encontrar sua garantia nas leis estabelecidas, ou na promessa de um monarca, faz valer sua autoridade, na expectativa de confirmação pública, em razão de um apelo à consciência pública..." (Lefort, 1991:55) .

Em síntese, a sociedade complexa é pensada politicamente pelo caminho da invenção democrática. Esta, por sua vez, é resgatada a partir do significado dos direitos para a nova ordem social, que, em conseqüência, se alimenta da afirmação e do exercício de direitos bem como do alargamento do espaço público. O otimismo com a sociedade democrática moderna está atrelado ao processo de constante reinvenção dos direitos, e da existência de um espaço público ampliado, próprio para a afirmação destes direitos. As experiências totalitárias recentes, com a ruína dos direitos humanos e das liberdades civis começaram, sempre, com o colapso da democracia e do Estado de direito. Regimes totalitários de direita, como o nazismo e o fascismo, ou de esquerda, como a experiência da antiga União Soviética, por exemplo, são sempre antimodernos. Mostram uma intolerância enorme diante da autonomia, quer dos indivíduos, na esfera privada, quer da autonomia que se 
expressa no âmbito político, através do voto. Esses regimes, através do questionamento da legitimidade do Estado de direito e da democracia, culminam por acabar com a livre expressão da cidadania.

Uma característica fundamental da democracia é fazer emergir um novo domínio público. Não somente novas questões emergem e são politizadas neste espaço, como também novos sujeitos sociais, com novas reivindicações, aparecem no cenário político.

Segundo Lefort, é forçoso considerar que o desdobramento dos direitos implica o reconhecimento de novos sujeitos e de novas identidades, que, ao apelarem aos princípios da liberdade pública e dos direitos básicos do homem, podem alargar a própria dimensão do público e o sentido do exercício político. Esse processo vincula-se à noção, cunhada por Arendt, de direito a ter direitos (Lefort, 1991:55). Com efeito, uma das argumentações centrais do autor diz respeito a não-separação dos direitos tidos por fundamentais (os direitos do homem), daqueles que são frutos de conquistas mais recentes (Lefort, 1991:55). O reconhecimento dessa característica inicial, inerente à cidadania, permite o alargamento posterior, e sempre desejável, do escopo dos direitos. Ao mesmo tempo, estende-se, ao conjunto da cidadania, o direito de ação, de resistência e de luta em prol de novos direitos.

Nessa medida, é necessário insistir, o exercício de um direito pressupõe a conformação de sujeitos sociais, individuais ou coletivos, que adquirem, no processo, capacidade de vocalização. Isto é, capacidade de se fazerem ouvir e de se representarem no espaço público, e de introduzir novas reivindicações e novos temas para o debate público. $\mathrm{O}$ público resulta, por assim dizer, de organização, de conquistas e de lutas sociais prévias, na conformação e no reconhecimento de atores políticos, ou seja, na experiência da cidadania ativa. Da mesma forma que os direitos mais recentes são inseparáveis dos direitos básicos do homem, o conjunto dos direitos parece também inseparável da consciência política quanto aos mesmos; não há afirmação de direitos sem a emergência de sujeitos políticos no espaço público.

Assim, as prerrogativas da sociedade liberal e democrática tornam possíveis reivindicações e contestações da ordem, e fazem avançar a discussão sobre os valores especificamente ligados à liberdade e à igualdade. O importante é perceber que a consciência, o debate e a politização do abismo entre normas/direitos e realidade social, sem dúvida, marcam a trajetória da época moderna. O pensamento marxista e os ideais socialistas representam a radicalização dessa consciência, e a denúncia da distância entre norma e fato social, e representam, portanto, a procura de princípios de justiça social. novos sujeitos sociais

direito a ter direitos

capacidade

de vocalização reivindicações

e contestações da ordem

social 
público e privado
$\mathrm{Na}$ modernidade e nas sociedades plurais, de outro lado, as fronteiras entre público e privado estão em permanente discussão e revisão. O princípio da autonomia e da individualidade estimula, como vimos, a diferença e a necessidade de ser essa diferença publicamente reconhecida. A modernidade, assim, faz emergir um espaço heterogêneo e ambíguo, porém coerente com a constante renovação de atores e temas que compõem a esfera pública. Institui-se uma nova forma de sociedade baseada numa figura simbólica...

"O lugar do poder, nela, se apresenta como um lugar vazio. É um lugar que não pode ser ocupado por ninguém; aqueles que exercem a autoridade política o fazem temporariamente, ao final de uma competição cujas condições devem ser conservadas. A legitimidade do poder de fato está assim ligada à permanência do conflito: suas bases nunca estão asseguradas. Ao mesmo tempo, a sociedade sabe que está dividida; o conflito político aponta para o conflito social; os interesses se nomeiam e se defrontam; os direitos adquiridos acarretam o desejo de mais direitos" (Lefort, 1989:136).

\section{Cidadania, e seus desdobramentos}

cidadania

O processo de expansão e de desenvolvimento da cidadania é o fio condutor do conflito moderno, e o eixo estruturador da nova sociedade. Sem a reinvenção constante da autonomia humana, é impossível aprofundar e ampliar os direitos na sociedade atual. Dessa forma, o conceito clássico de cidadania, de Marshall, um dos teóricos mais famosos desse tema, constitui a pedra angular para seu entendimento. Em suas palavras, "a cidadania é um status concedido àqueles que são membros integrais de uma comunidade. Todos aqueles que possuem o status são iguais com respeito aos direitos e obrigações pertinentes ao status. Não há nenhum princípio universal que determine o que estes direitos $\mathrm{e}$ obrigações serão, mas as sociedades nas quais a cidadania é uma instituição em desenvolvimento criam uma imagem de uma cidadania ideal em relação à qual o sucesso pode ser medido e em relação à qual a aspiração pode ser dirigida. A insistência em seguir o caminho assim determinado equivale a uma insistência por uma medida efetiva de igualdade, um enriquecimento da matéria-prima do status e um aumento no número daqueles a quem é conferido o status" (Marshall, 1967:76).

"O conceito de cidadania, assim, não se resume à posse de determinado conjunto de direitos, que podem variar de sociedade para sociedade de acordo com diferenças concretas. Antes, ela (cidadania) implica 
possuir os mesmos direitos, na esfera civil, do político e do social" (Marshall, 1967:63).

Aqui aparecem, em resumo, as duas idéias básicas do autor. A cidadania como o princípio jurídico da igualdade de direitos, e a célebre divisão entre os três elementos ou dimensões que compõem a noção de cidadania: civil, político e social. O direito civil, segundo indicações do autor, serve de fundamento e de patamar mínimo para os demais: "é composto dos direitos necessários à liberdade individual - liberdade de ir e vir, liberdade de imprensa, pensamento e fé, o direito à propriedade e de concluir contratos válidos e o direito à justiça. Este último difere dos outros porque é o direito de defender e afirmar todos os direitos em termos de igualdade com os outros e pelo devido encaminhamento processual" (Marshall, 1967:63).

Mas as conquistas em torno das liberdades políticas e do próprio exercício da democracia constituem um aspecto inseparável da cidadania. O direito político, como o próprio Marshall o mostra, deve ser entendido como o direito de participar no exercício do poder político. Já a noção de direito social, na análise do autor, diz respeito ao direito de um mínimo de bem-estar econômico e de segurança, e abrange o direito de participar, por completo, na herança social e de levar uma vida de ser civilizado, de acordo com os padrões que prevalecem na sociedade (Marshall, 1967:63-64). Isto significa que a consolidação da cidadania atrela-se à forte consciência, adquirida na experiência democrática da maioria dos países ocidentais, do valor dos direitos e das prerrogativas políticas da democracia moderna.

Trata-se de pensar, aqui, no processo através do qual conflitos, temas e interesses sociais são traduzidos em ação política. Isto é, o sentido democrático dos direitos repousa na reinvenção de novos espaços, novas temáticas e, portanto, de novos atores. Isso nos coloca diante da fluidez e da pluralidade inerentes ao conflito moderno. A modernidade deve ser entendida também como um valor, um estilo de vida, enfim, como uma experiência social (Bodstein, 1997). Os direitos sociais acompanham a extensão da democracia a outros espaços e a novas temáticas sociais: questões do universo da produção e do trabalho; do desemprego; da desigualdade no acesso à escola e aos demais bens da infra-estrutura social de cada país; as questões ligadas à desigualdades entre gêneros, etc. Todas estas temáticas necessitam de atores que denunciem injustiças e desigualdades, e, a partir daí, afirmem direitos. Tais direitos só adquirem legitimidade no espaço público graças à presença organizada desses atores e à sua capacidade de "vocalização de demandas." As injustiças e desigualdades precisam ganhar visibilidade pública, ou não serão consideradas injustiças e desigualdades "sociais." direito civil

direito politico

direito social

ação política 
democracia

cidadania

e diversidade
Nessa perspectiva compreende-se que as três dimensões da cidadania, definidas por Marshall, se articulam intrinsecamente e que o avanço na cidadania social, na conquista de direitos sociais, é inseparável da igualdade civil e da liberdade política. Se pensarmos, por exemplo, que o traço mais marcante da democracia é a igualdade, fica mais fácil entender essa articulação intrínseca das dimensões da cidadania.

A democracia pressupõe não a igualdade entre pobres e ricos, não o fim da distância, ou do abismo, entre as classes sociais. A igualdade referida diz respeito a essa desigualdade social não estar enraizada, fundamentalmente, na hierarquia preexistente e na transmissão familiar. A democracia não elimina a diferenciação entre as classes, mas modifica a base sobre a qual essa relação é construída. A democracia projeta uma sociedade idealmente igualitária, no sentido de que, apesar das diferenças e desigualdades acentuadas entre as classes, propõe uma base comum, condições básicas de igualdade: todos se podem definir como cidadãos, com os mesmos direitos. A igualdade que se define assim, e que as relações democráticas procuram proteger, situa-se no plano da norma e das regras sociais, e não no plano das condições materiais de vida. A democracia é, assim, inseparável da crença na igualdade como valor. A democracia permite, enfim, que a distância abusiva ou abissal entre fatos e valores, que existe, em maior ou menor escala, em todas as sociedades humanas, seja legitimamente denunciada. Em última instância, a sociedade democrática moderna visa garantir o direito a reivindicar direitos, e a denúncia de injustiças e desigualdades sociais.

Da mesma forma, temos que reconhecer que se a ordem social moderna não acaba com a pobreza e a desigualdade, nem tampouco com a radical diferença entre as classes, pelo menos introduz uma base de igualdade jurídica, isto é, fundada nos direitos humanos, ou nos chamados direitos naturais. É preciso lembrar ser o protesto indignado contra as desigualdades sociais, na medida em que são fixas e herdadas, parte constituinte da ideologia individualista e da noção de modernidade (Dumont, 1993:93).

O sentido sociológico da cidadania diz respeito a uma representação de igualdade e de justiça que caminha junto com a concepção individualista da sociedade. Isto é, a cidadania é o terreno compartilhado que define, em termos jurídicos, o que todos os seres humanos têm em comum, para as pessoas terem liberdade de ser diferentes (Dahrendorf, 1997:52-53). A cidadania incentiva, portanto, a diversidade, pois cria instrumentos para lidar com a mesma.

Outro aspecto igualmente importante refere-se ao fato de que as dimensões civil e política da cidadania, apesar das intensas reações históricas suscitadas, não ameaçaram diretamente o legado da tradição do 
pensamento liberal. Já os avanços dos direitos sociais, ainda que inseparáveis das outras dimensões da cidadania e da própria consolidação do processo democrático, provocam, na atualidade, uma reação mais intensa das forças políticas, entrincheiradas em um novo movimento, reacionário, de oposição aos novos papéis do Estado: o chamado neoliberalismo. Mas, antes de entendermos as concepções neoliberais tão difundidas hoje em dia, devemos compreender o processo de complexificação do próprio Estado.

\section{Estado e processo de coletivização}

É necessário introduzir uma nova dimensão na discussão até aqui desenvolvida, que diz respeito à noção de Estado-Nação, que é também uma das principais conseqüências da sociedade moderna. Paradoxalmente, junto à afirmação do individualismo, da liberdade e dos direitos, a vida na sociedade moderna encontra-se cada vez mais moldada, em seus aspectos cotidianos e em seus microespaços, pela presença do Estado. Onde se busca autonomia do sujeito, liberdade da sociedade civil e fortalecimento do espaço público, encontram-se poderosos processos de coletivização. Como explicar esse fenômeno aparentemente paradoxal e contraditório, em que se defrontam processos de individualização a processos de coletivização?

O longo processo civilizador, como nos mostra Elias (1990), com seus mecanismos de disciplinarização e autocontrole, dá a chave para o entendimento da presença extraordinária e crescente do Estado nas sociedades complexas. O processo civilizador diz respeito ao fato de que, sob a pressão da competição, e portanto, da individualização e do mercado - ante a obrigação de cada um se destacar e de ser o melhor -, as funções sociais tornam-se cada vez mais diferenciadas, mais especializadas, porém dependentes umas das outras; e exigem, portanto, um comportamento mais estável, previsível e regulado. Daí a pressão, socialmente difusa, para que todos os indivíduos obtenham maior autocontrole, de acordo com as necessidades dessa nova cadeia de interdependência.

Nas sociedades complexas, dessa maneira, formam-se redes de interdependência cada vez maiores, fato que a constituição das fábricas e das grandes unidades produtivas e, também, dos espaços urbanos, não nos deixa esquecer. A interdependência coloca, para todos os envolvidos (no espaço da produção ou no local de moradia), novos e crescentes riscos, advindos quer da perda individual do autocontrole, quer do desvio de padrões éticos e morais. Mais do que isso, através da interdepen- individualizaçăo

e coletivizaçăo

redes de

interdependência 
externalidade

associaçōes da sociedade civil risco dência podemos entender que a ameaça a uns poucos, ou a um só indivíduo, tem a potencialidade de transformar-se, às vezes em curto espaço de tempo, em ameaça a toda a coletividade.

O conceito de "efeito externo" ou "externalidade" procura exatamente dar conta de deficiências, efeitos negativos ou colaterais, enfim, de adversidades que acabam por atingir e prejudicar outras pessoas ou o conjunto da sociedade, além daquelas diretamente responsáveis ou envolvidas (Bodstein, 1995). Um exemplo típico pode ser dado pelas externalidades causadas pela ocorrência de surtos de doenças infectocontagiosas, que, se não controlados, ameaçam a sobrevivência do conjunto da coletividade. A produção de medicamentos, de vacinas, de alimentos e bebidas, o controle da qualidade da água, entre outros, pela abrangência e pelos riscos sanitários intrínsecos, são exemplos da importância de organismos públicos de controle e vigilância, para se evitar, ao máximo, a propagação e a difusão do risco.

Além dos órgãos públicos encarregados do controle dessas situações, é comum o aparecimento de associações da sociedade civil que tentam chamar a atenção pública para determinados problemas, riscos ou ameaças. São organismos de defesa da cidadania que lutam quer pelos direitos do consumidor em geral, quer pelos direitos dos doentes, dos menores, dos consumidores, etc. Nas grandes concentrações urbanas, as externalidades (riscos sanitários, epidêmicos, violência descontrolada, etc) afetam muito rapidamente a população como um todo, e demonstram, entre outras coisas, a nova dimensão que assume o fenômeno da interdependência em sociedades complexas. Esse fenômeno, sem dúvida, coloca novos e crescentes desafios à ação coletiva, e exige, por sua vez, um novo perfil de intervenção do Estado e de implementação de políticas públicas de saúde e de Vigilância Sanitária.

As interdependências típicas da nova ordem social só fazem aprofundar e trazer para o centro da agenda política atual o conceito de risco. Ao Estado, envolvido no crescimento e desenvolvimento econômico, caberá, daqui para a frente, o exercício das funções de autocontrole social em esferas da vida e em tipos de comportamento antes considerados de âmbito privado e familiar. A coletivização aparece, assim, como contrapartida ao processo de individualização: como necessidade de tornar viáveis ações coletivamente coordenadas tanto para evitar riscos e perdas socialmente relevantes quanto para a obtenção de bens públicos. Esses bens, segundo Rawls, não podem ser divididos quantitativamente, e sua provisão passa, necessariamente, por arranjos políticos, e não pelo mercado (Rawls, 1971:266-267). A distribuição e a oferta dos mesmos requer, quase sempre, uma estrutura financeira e administrativa complexa. 
Quando estão em jogo deficiências, adversidades e riscos que afetam pessoas que não aquelas diretamente envolvidas, a intervenção do Estado, e sua capacidade de planejamento e de coordenação são fundamentais, já que medidas preventivas são sempre necessárias. Trata-se da produção de bens, serviços e valores impossíveis de serem produzidos/gerenciados espontaneamente, de forma privada, ou exclusiva pelo mercado.

O Estado contemporâneo estabelece, e procura fortalecer, um largo aparato burocrático e jurídico, para equacionar conflitos que, inevitavelmente, surgem no enfrentamento das questões e assuntos que, em dado momento, aparecem como disfuncionais ou de risco e, portanto, são de interesse público. O Estado passa, assim, diante da complexificação das sociedades contemporâneas, a gerenciar e controlar um número considerável de questões ligadas à pobreza, ao crescimento populacional, ao meio ambiente, à sexualidade, ao adoecer, à morte, à intensificação do processo de urbanização, de produção de bens e serviços, etc. E acaba por criar sistemas nacionais de previdência e de assistência social, enfim, de tratamento dos doentes, dos loucos, dos deficientes, das crianças, das gestantes, de vigilância da saúde, etc. Cabe ao Estado coordenar e operacionalizar, portanto, questões que, uma determinada coletividade identifica e vocaliza como "públicas ou coletivas" e cujas externalidades, quando não enfrentadas, representam um custo social bastante elevado.

Não existe, é bom salientar, uma natureza intrinsecamente coletiva ou pública de um dado bem, serviço ou problemática. Em princípio, tudo, ou quase tudo, numa sociedade em processo de complexificação, pode ser representado como um "bem coletivo", já que, nessas sociedades são sempre novas e crescentes as redes de interdependência, e sempre se formam novos sujeitos de direito. Assim, nas formações sociais modernas coloca-se, pari passu, a crescente interdependência, e a necessidade de ações coletivamente orientadas e de intervenções e controles públicos que procurem eficiência e efetividade crescentes.

A ordem social contemporânea, na perspectiva aqui privilegiada, implica um redimensionamento da dependência mútua, das próprias necessidades de convivência em sociedade, dos vínculos de solidariedade e de cooperação, implica um novo perfil de Estado. Importa ressaltar que o processo de coletivização, ao criar ou consolidar interesses comuns, produz, simultaneamente, uma dada representação de cidadania mais ou menos integrada e solidária diante de interesses e de bens públicos. A coletivização é um processo que pressupõe idéias, motivações, valores, ou seja, a percepção dos próprios atores, a definir e, redefinir, quando necessário, se um determinado assunto, bem ou serviço

solidariedade e cooperação 
espaço público

aperfeiçoamento da ação coletiva e de instâncias administrativas reguladoras deve ser ou não elevado à esfera pública e sujeito ao controle público e à regulação estatal.

O espaço público, como conquista da democracia e do exercício da cidadania, sofre, como vimos, um processo de intensa complexificação, em decorrência da multiplicação de sujeitos, identidades e instituições que compõem a vida moderna. A coletividade formada de cidadãos de um determinado estado nacional, implica uma estabilidade consideravelmente maior do que aquela constituída, por exemplo, em torno dos usuários de serviços de saúde ou de consumidores de medicamentos falsificados ou de sangue contaminado. Por este caminho entendemos a causa da fragmentação e da fluidez das formas de organização das sociedades complexas.

Os movimentos sociais, atualmente, acompanham essa metamorfose de interesses, identidades e atores, em permanente processo de renovação. Por outro lado, convém não esquecer que existe, para as sociedades modernas, um conjunto básico de questões que devem ter um controle mais direto do Estado e do governo: exército e segurança pública, arrecadação de impostos, Vigilância Sanitária, etc. Mas, a partir daí, outras questões estão presentes, conforme a demanda social, e a capacidade de investimento dos setores público e privado: saneamento e abastecimento d'água, transportes, serviços de comunicação, produção de vacinas etc. Daí a necessidade de aperfeiçoamento da capacidade de ação coletiva e de instâncias administrativas reguladoras destas políticas, que envolvem negociações, complexos e delicados arranjos políticos e, às vezes, longos processos de tomada de decisões.

Assim, fenômenos que provocam grandes e extensas externalidades, ou que deixam em evidência aquilo que De Swann chama de "paradigma da interdependência urbana" (De Swann, 1988:124), merecem prioridade e exigem soluções negociadas, com intuito de se atingir um determinado consenso. O caráter público, neste caso, é bastante evidente, sendo difícil imaginar indivíduos, ou setores da sociedade, que não tenham interesse, diretamente, em uma solução a curto e médio prazos desses problemas. A defesa e a fiscalização dos alimentos e dos mananciais d'água que abastecem uma determinada cidade ou povoado são exemplos claros da necessidade de ação coletiva para solucionar, ou prevenir, um problema que ameaça a sobrevivência de todos.

A consciência do alcance e da intensidade dos efeitos externos condicionam, em grande parte, a resposta da sociedade, que pode ser de caráter público ou privado. $\mathrm{O}$ fato de a sociedade já apresentar um aparato estatal, mais ou menos organizado, e com alguma garantia de eficiência e eficácia em suas políticas, influi, decisivamente, na opção pelo setor público. Em casos de possíveis surtos de intoxicação alimentar, de 
medicamentos ou de sangue contaminados, é necessário o estabelecimento urgente e emergencial de um conjunto de ações governamentais eficientes, voltadas para a vigilância e a prevenção (muitas vezes implicando a adoção de medidas preventivas mais amplas e ações de saneamento urbano), e a adoção de medidas voltadas para determinados grupos de risco e para o tratamento dos doentes, etc.

O fortalecimento e o extraordinário crescimento do Estado na sociedade contemporânea, consagrado sob a denominação de Estado regulador, é, em grande parte, fruto do processo de complexificação, e de interdependência mútua e da tentativa de evitar incertezas, riscos e infortúnios. Certamente a coletivização de inúmeros aspectos e dimensões da vida social pressupõe tanto o processo de ação coletiva como a formação das mais variadas identidades e interesses vinculados a diferentes atores sociais.

Em resumo, o que se procura demonstrar é que o fortalecimento do mundo privado, e do próprio mercado, caminha, pari passu, com o processo de coletivização e de alargamento do espaço público. Dessa forma, há que se perceber que a modernidade recupera o indivíduo, em sua singularidade, para, em um mesmo movimento, colocá-lo na cena pública, sob a proteção do Estado.

\section{Estado de bem estar social e neoliberalismo}

Como vimos, a complexificação das relações entre Estado e Sociedade coloca em novo patamar a discussão política. Nesse sentido, é necessário o aprofundamento das formas de convivência e de colaboração entre mercado e justiça social ou, ainda, entre desenvolvimento econômico e política distributiva e de justiça social. Essa necessidade ensejou o aparecimento, no decorrer do século XX, do chamado Estado de Bem Estar Social, com a ampliação dos direitos e prerrogativas sociais, a criação do sistema de proteção pelo sistema previdenciário e a multiplicação dos serviços assistenciais. O problema político passa a ser agora, o de compatibilizar direitos sociais ampliados, crescimento econômico e livre mercado.

O exercício dos direitos pressupõe, como vimos, o reconhecimento e a legitimidade da fala e da opinião de atores políticos, que se constituem, justamente, em movimentos de resistência ou de reivindicações por novos direitos. É assim que se multiplicam as instâncias de representações da sociedade civil: órgãos de defesa do consumidor, de proteção à mulher, ao índio, ao menor, ao aidético, numa infinidade de instâncias, de temáticas e de novos segmentos sociais ou minorias organi-

\section{Estado regulador}

ampliação dos direitos

e prerrogativas sociais 
crise do capitalismo

neoliberalismo

desregulamentação

mercado

Estado minimo não-intervencionista zadas. Por outro lado, é necessário esclarecer que o sentido do Estado de Bem Estar Social se dá pelo desdobramento das políticas sociais em diversos setores, de abrangência diversa: serviços sociais propriamente ditos, políticas fiscais, legislações trabalhista, sanitária e previdenciária. Esse conjunto de medidas simultâneas, em setores tão diversificados e abrangentes, ultrapassa medidas pontuais e emergenciais de assistência e previdência social, e constitui, propriamente, o sistema denominado de proteção e de bem estar.

A ação governamental, nos países de capitalismo avançado, de conciliação de todos esses setores e interesses, num arranjo complexo, logrou êxito desde o período após a segunda guerra até meados dos anos 70. Porém, a crise do capitalismo, e seus efeitos mundiais, no início da década de 70, provocou um desgaste da concepção do Estado Social e novos argumentos em favor do Estado Mínimo. Assim, ganhou ênfaze o antagonismo entre desenvolvimento, crescimento econômico, mercado livre, livre concorrência, de um lado, e políticas sociais, de outro.

Fortalecimento do mercado e intervenção estatal, principalmente aquela de caráter social, nesse contexto, parecem à beira de um divórcio definitivo, marcado por conflitos e antagonismos irreconciliáveis. $\mathrm{O}$ impacto da crise econômica trouxe à ordem do dia, no final dos anos 70 , as teses neoliberais, que advogam o fim da manutenção do padrão intervencionista e regulador do Estado.

As críticas mais reacionárias às políticas sociais do Estado passam a se congregar, então, em torno do chamado neoliberalismo, em torno de um conjunto de idéias de defesa, intransigente, da economia de mercado e da desregulamentação econômica. O novo liberalismo emerge como uma clara reação às teses em prol do planejamento econômico centralizado e do intervencionismo estatal. O ponto central da matriz teórica do neoliberalismo é o apego à idéia de que o mercado se regula por si mesmo e que, portanto, qualquer intervenção neste mecanismo provoca desequilíbrios e efeitos nocivos, e afeta o conjunto da sociedade. As políticas governamentais de proteção e bem-estar social, incluindo medidas de combate à pobreza e de assistência social, são vistas com extrema desconfiança, ou explícita hostilidade. Isto é, as proposições neoliberais defendem, senão o fim, pelo menos a redução da intervenção do Estado e do poder público na área social. Ora, como sabemos, populações inteiras, marginais e periféricas ao mercado e, por isso mesmo, de baixo poder aquisitivo, ficariam, se seguíssemos o receituário neoliberal, sem acesso aos serviços de educação, saúde, previdência, etc. A política de defesa de um Estado mínimo não-intervencionista, na verdade, acaba por reforçar a marginalização de segmentos inteiros da 
população. Esses segmentos, se entregues à própria sorte, sem proteção do Estado, nunca poderão comprar esses bens no mercado.

O projeto democrático, e em prol de um novo Estado, mais dinâmico, mais eficiente e menos atrelado a interesses corporativos, está em jogo atualmente. A questão política relevante tem sido a de como estender os espaços e os assuntos sobre os quais as decisões são tomadas de forma democrática, sem afetar a eficiência econômica.

Este é o contexto em que se dá o debate sobre a reforma do Estado, na medida em que tanto o poder público como o governo têm responsabilidade pela promoção de políticas redistributivas e de maior justiça social. Daí a convivência difícil, hoje em dia, entre o pensamento que entende como benéfica a ampliação das decisões democráticas, e o neoliberalismo, que defende o mercado como o único e legítimo mecanismo de regulação social. Mas é conveniente observar que a pura ótica do mercado, do lucro e do aumento da produção, sem a presença de um Estado forte, tem promovido, sempre, o esmagamento dos interesses públicos e dos mecanismos institucionais de regulação e promoção dos bens coletivos.

Por outro lado, devemos reconhecer que o ponto chave do debate se dá em torno dos custos e benefícios do atual sistema de proteção e de assistência social, em uma conjuntura econômica recessiva. Este debate certamente interessa a todos, já que põe em questão a preservação da capacidade de regulação do Estado e seus efeitos sobre as políticas sociais. Isto é, devemos ter a ousadia de reconhecer que nem todas as medidas assistenciais, de proteção social ou previdenciárias, são socialmente justas. Ao contrário, podem estar defendendo interesses de determinadas corporações e de minorias que desfrutam privilégios no interior do aparelho estatal. Isto é, trata-se de pensar na possibilidade da existência de políticas sociais que de sociais só têm o nome, já que, perversamente, estão voltadas para reforçar privilégios de setores e segmentos sociais minoritários.

A polêmica, envolve, portanto, a relação entre direitos sociais e o conjunto de propostas do Estado protetor ou social, tendo em vista que muitos interesses, muitos "direitos", escondem, na verdade, inúmeros privilégios. É necessário reconhecer que a universalidade e a igualdade de direitos nem sempre promovem justiça distributiva e maior eqüidade. Ao contrário, muitas vezes, provocam o aumento das desigualdades sociais. Justiça social diz respeito ao reconhecimento, pelo governo, de situações críticas de desigualdade social e à implementação de políticas públicas apoiadas no critério da eqüidade. Assim, freqüentemente, as políticas sociais e de regulação do Estado, quando preocupadas com a eqüidade, devem, em princípio, estar voltadas para os que mais neces- custos e benefícios do atual sistema de proteção e de assistência social 
efeitos perversos

e indesejáveis

do desenvolvimento

da ciência e da técnica sitam, e discriminar e focalizar, quando for o caso, determinadas políticas e determinados segmentos sociais que merecem prioridade.

\section{Estado regulador e a globalização}

Em razão da complexidade da sociedade moderna, aos problemas redistributivos (renda, emprego, proteção e seguro social), típicos de uma agenda social e do perfil do chamado Estado de Bem Estar Social, aliam-se problemas relativos aos riscos e ameaças que envolvem a própria produção de bens (Beck, 1997:17). É preciso reconhecer e analisar a imprevisibilidade das ameaças provocadas pelo desenvolvimento técnico - industrial. Estamos pois, na virada do novo milênio, diante do que sociólogos chamam de conseqüências da modernidade (Giddens, 1991). Essas são, paradoxalmente, efeitos perversos, ou imprevisíveis, do próprio progresso e do desenvolvimento tecnológico, de externalidades geradas a partir dos, e através dos, meios e instrumentos mais avançados que a sociedade e a ciência contemporânea desenvolveram.

As ciências sociais foram unânimes em apontar os efeitos perversos da emergência do trabalho industrial, em termos de degradação das condições higiênicas, da introdução precoce no mercado dos menores e das mulheres, etc. Porém, não conseguiu prever todo o potencial destrutivo da ciência e da técnica em relação ao meio ambiente, e gerou uma descrença profunda em relação ao progresso tecnológico e científico (Giddens, 1991:17-18). Uma das mais sérias conseqüências da modernidade é a emergência da denominada sociedade de risco: "uma fase no desenvolvimento da sociedade moderna, em que os riscos sociais, políticos, econômicos e individuais tendem cada vez mais a escapar das instituições para o controle e a proteção da sociedade industrial" (Beck, 1997:15-17).

Os efeitos perversos e indesejáveis do desenvolvimento da ciência e da técnica tornam-se, agora, particularmente visíveis, e fontes de riscos globais incontroláveis. A tecnologia nuclear, a engenharia genética e a microeletrônica formam o novo tripé do desenvolvimento econômico. Riscos e incertezas nesse contexto se multiplicam e se globalizam, exigindo, algumas vezes, soluções ainda não vislumbradas. Nesse sentido, a insegurança parece dar o tom da nova sociedade pós-industrial e informatizada, que não compartilha mais da crença ingênua na ciência e na técnica. Diante das incertezas quanto ao rumo do desenvolvimento, o papel e a responsabilidade do Estado são gigantescos, e é importante reconhecer a necessidade de fomentar parcerias entre o Estado $e$ o mercado, ou entre a sociedade civil e o governo. 
Nesse cenário, é essencial perceber que o Estado deve ser redefinido ou reformado, para adquirir, paradoxalmente, um papel maior e mais complexo. A nova sociedade informatizada e globalizada impõe novos desafios. Do ponto de vista político, o Estado é confrontado, e de certa forma ameaçado, for todo o tipo de interesse, de grupos de pressão e de minorias politicamente ativas. Assim, quando se fala em reforma do Estado, está em jogo a definição de um novo modelo que supere tanto o Estado mínimo como o Estado autoritário intervencionista, pouco ágil em dar respostas e encontrar as soluções que a sociedade exige. Assim, o Estado deve ser compreendido como um arranjo político complexo, cada vez mais necessário para a manutenção e o aprofundamento da democracia. Democracia, aliás, particularmente problemática, dada a interdependência crescente das sociedades atuais, confrontadas com a pluralidade de movimentos, de interesses e de demandas setoriais em permanente conflito. E, principalmente, com o poder globalizante do capital financeiro especulativo.

A globalização da economia e a generalização da chamada sociedade pós-industrial levam o fenômeno da interdependência a novos e perigosos patamares. A globalização, sob o nosso ponto de vista, deve ser vista como inerente à modernidade. Nessa medida, representa um processo de intensificação das relações sociais em escala mundial, a ligar localidades distantes e a interconectar eventos e acontecimentos (Giddens, 1991:69). As tecnologias da informação aproximam pessoas, e tornam, de fato, possível a referência a uma aldeia global. Ao mesmo tempo, tornam mais visíveis e traumáticos os efeitos da questão social, da miséria e da pobreza, bem como os desequilíbrios do mercado e os riscos tecnológicos, que exigem nova e crescente capacidade de ação coletiva e de eficiência administrativa do Estado.

Longe de permitir um processo de enfraquecimento do Estado, o fenômeno da globalização tem exigido a redefinição dos campos de responsabilidade dos governos. Cabe ao Estado um conjunto inteiramente novo de tarefas, cabe-lhe concentrar seus esforços em criar alternativas e buscar soluções para riscos futuros e para aquelas conseqüências inesperadas do desenvolvimento tecnológico. Na área da saúde, o desenvolvimento acelerado de novas tecnologias médico-terapêuticas e de novos medicamentos que, em semanas, estão disponíveis em vários continentes e países, assim como a presença dos chamados vírus emergentes, impõem uma responsabilidade maior aos antigos setores de Vigilância Sanitária.

É possîvel pensar na criação de instâncias jurídicas globais (justiça globalizada para julgar crimes contra a humanidade ou contra os direitos humanos), órgãos de defesa do meio ambiente e da vida e de defesa reforma do Estado

globalização

responsabilidade da Vigilância Sanitária 
paises de capitalismo maduro dos consumidores, agências internacionais de vigilância em saúde com eficiência para além dos limites do Estado-Nação. Esse cenário, sem dúvida, permite compreender o fenômeno da globalização em uma perspectiva mais abrangente, em toda a complexidade dos seus efeitos e desdobramentos atuais.

Assim, a consolidação dos direitos sociais, durante o século XX, diz respeito a um processo de democratização da sociedade que dá origem ao Estado de Serviço ou de Bem-estar, Estado Assistencial ou Social, em oposição ao Estado mínimo e à simples regulação pelo mercado. Dá-se a complexificação do Estado e do processo de extensão da democracia a outras esferas da vida, a diversos aspectos da sociedade civil. Ora, tal processo exige, ao contrário do que reza a tradição liberal, uma intervenção estatal de novo tipo, como vimos, mais efetiva e eficiente diante dos riscos e ameaças que se globalizam de maneira acelerada e surpreendente. A globalização dos mercados e da economia e a hegemonia do capital especulativo compõem, sem dúvida, esse novo contexto.

Então, ao Estado Mínimo opõe-se hoje não só o Estado Social, mas um aparato estatal de novo tipo, para acompanhar, com a rapidez necessária, as transformações radicais desse novo contexto de final de milênio. Ou seja, consolida-se a consciência de ser necessário redesenhar o Estado, já que lhe cabem não só funções redistributivas, de eqüidade $\mathrm{e}$ de justiça social típicas de uma agenda do estado assistencial (Estado de bem-estar social), mas outras tantas funções de regulamentação, de controle e de vigilância, algumas delas ultrapassando as fronteiras nacionais.

Os governos dos países de capitalismo maduro e mais desenvolvidos, mesmo que apregoando, para efeito externo, as concepções neoliberais e do Estado Mínimo, exercem, internamente, uma pesada política regulatória. Não abrem mão, portanto, de manter um eficiente aparato técnico-burocrático para regular, fiscalizar e disciplinar o mercado. Aparato apoiado em leis e ações jurídicas, rápidas e eficazes, para evitar, ou punir, abusos, sobre a economia e o mercado, ou sobre os cidadãos e consumidores, em geral. A presença regulatória do poder público e do Estado é forte nos diversos setores da economia e da sociedade. O governo, no contexto atual dos países de economia avançada, não se envolve diretamente no sistema produtivo, ou pelo menos evita tal envolvimento. Mas nem por isso deixa o mercado caminhar totalmente livre, sem regras e normas disciplinares rígidas. São inúmeros os órgãos de regulamentação, de controle e de fiscalização do Estado, hoje em dia, voltados para disciplinar o mercado. Medidas de qualidade e padrões mínimos de segurança são constantemente avaliados e exigidos. Na área da saúde, da segurança e da proteção dos consumidores, 
as medidas e os órgãos de fiscalização são particularmente fortes e têm alta eficiência, e procuram sempre manter independência e autonomia diante das pressões do mercado e dos responsáveis pela produção de bens e serviços.

Em resumo, é necessário reconhecer que a globalização e a consolidação de sociedades altamente informatizadas colocam em um novo patamar a discussão dos efeitos perversos e danosos do desenfreado desenvolvimento tecnológico. Sem dúvida, tais processos abrem a possibilidade - positiva para a humanidade como um todo -, da instituição de organismos e fóruns globais de discussão dos mais diversos assuntos e interesses da cidadania, e das possíveis conseqüências perversas da introdução, no mercado globalizado, de novos produtos e processos. E trazem as questões da ética, diante da vida humana e da vida de todos os seres vivos, ao centro do debate da ciência contemporânea. Assim, é fundamental, mais do que nunca, exercer o controle e a regulamentação pública dos avanços científicos e tecnológicos que interferem, direta ou indiretamente, na saúde e na vida.

\section{Cidadania, direito e Estado no Brasil}

$\mathrm{Na}$ sociedade brasileira, em particular, modernização e "individualização" implicam um longo processo de incorporação de novas regras, e orientam, no cotidiano, a transformação das relações sociais, de rompimento com os princípios antiigualitários, tão cristalizados na ideologia e na cultura nacionais. Trata-se de fortalecer órgãos de representação coletiva de interesses, por meio de associações voluntárias, como os sindicatos, os partidos políticos, os órgãos de representação de classe e de defesa do consumidor, etc. É necessário um esforço a mais, já que tudo isso exige abrir-se mão de padrões e modelos de convivência social tão enraizados em nossa tradição, abrir-se mão dos direitos/privilégios do sangue, da filiação, do casamento, da amizade e do compadrio (Da Matta, 1983:180).

O processo de modernização e complexificação social pressupōe, como vimos, uma disciplinarização/coletivização rigorosa, capaz de preparar o caminho para que as relações sociais operem em um novo ambiente administrado e mediatizado pelo Estado, pela burocracia e pelas instituições da sociedade democrática-moderna. Ambiente este que exige um certo nível de despersonalização, burocratização e normatização. À primeira vista, tal processo parece implicar apenas a sujeição aos princípios jurídicos do Estado Moderno. Porém, é necessário observar que sem a vivência e o reconhecimento do sentido da individualiza- ética

representação coletiva de interesses 
ideologia paternalista e autoritária

hierarquização e desigualdade social

descrédito em relação ao Estado ção e do igualitarismo, é impossível a representação do valor das leis, e o próprio exercício da cidadania moderna.

Mais uma vez, é necessário enfatizar que o processo de individualização significa, antes de tudo, uma auto-representação dos indivíduos como iguais, porque igualmente portadores de direitos. Quer dizer, não só implica a ruptura com aspectos cruciais da ideologia paternalista e autoritária, mas, acima de tudo, pressupõe uma atitude ativa de participação na construção da ordem pública.

Assim, cabe enfatizar a contradição entre a ideologia aristocrática e antiigualitária, tão presente na sociedade brasileira, completamente avessa ao universalismo de direitos e deveres, e a concepção individualista. $\mathrm{Na}$ visão tradicionalista e hierárquica do social, como brilhantemente o mostrou Da Matta, as diferenças entre superiores e inferiores são tão bem marcadas que se permite certa intimidade e cordialidade entre estes dois segmentos sociais, e se cria um ambiente inicial propício à troca de favores. Mas, desde que os 'inferiores', na hierarquia social, ousem contestar relações estabelecidas tradicionalmente, e afirmar direitos, a harmonia e a cordialidade inicial se quebram. A ordem social moderna pressupõe a afirmação de direitos, e não o toma lá-dá-cá da troca de favores, de atitudes populistas e paternalistas, que acabam por negar aos inferiores, aos subalternos, ou aos pobres, o exercício da cidadania. A hierarquização e a desigualdade social, explícitas e escancaradas, traduzem uma profunda e assumida assimetria social.

A ausência de valores igualitários compartilhados, ou reivindicados, é exatamente o que dá margem à cordialidade, à camaradagem, à confiança e à troca de favores entre os dois pólos extremos da hierarquia social, imagem que as elites nacionais gostam de reafirmar a todo o momento. Como o explica Da Matta, na sociedade brasileira quase não há necessidade de segregação social ou racial, já que todos sabem seu lugar, suas obrigações e seus deveres. A discriminação só se explicita quando o indivíduo, por um motivo ou outro, não reconhece e não aceita seu lugar na rede de relações pessoais, e insiste em desafiar a tradição e a hierarquia. Cada indivíduo, nessa ordem tradicional, tem um lugar determinado, onde o princípio da cidadania e da igualdade quase nunca está presente, às vezes, nem mesmo no plano jurídico-formal. Isto acaba gerando um profundo descrédito, em especial dos que se situam na escala inferior da hierarquia social, em relação ao funcionamento das leis, do poder judiciário, e do Estado como instância de reafirmação do espaço público e do bem comum.

O poder público e o aparelho jurídico-legal, nesse caso, longe de promoverem uma igualdade de tratamento, reproduzem a desigualdade extrema, e beneficiam, via de regra, os estratos superiores e ameaçam, 
ou punem, as classes dominadas. As leis transfiguram-se em relações personalizadas, adaptam-se, passam a traduzir a imagem perfeita da distribuição de poder na sociedade. A questão, enfim, resume-se ao "manda quem pode, obedece quem tem juízo." Isto é, as leis são apropriadas de forma privada por aqueles que detêm o poder, e reforçam, sempre, os interesses dominantes.

A noção de res publica, ou seja, o sentido da separação entre o que é privado e o que é de interesse público, tem dificuldade de se afirmar na sociedade brasileira. Como conseqüência, a idéia de uma classe burocrática independente, baseada nos princípios impessoais, universalizantes e igualitários, preocupada com o bem público, também raramente está presente. Raramente, ou quase nunca, se aplica o procedimento comum de se identificar o caso com a regra geral. Ao contrário, ocorre uma freqüente separação entre a regra e a prática (Da Matta, 1983:143).

O mando e a subserviência, formas de dominação personalizadas, marcam o conjunto das relações sociais. A ideologia brasileira pode ser vista, ainda hoje, como a da síntese, a da conciliação sistemática das posições polares e antagônicas. Evitam-se, sempre que possível, o conflito e o confronto. Segundo Da Matta, ainda hoje "no Brasil impede-se, assim, a todo custo, a individualização que conduziria fatalmente ao confronto direto, inapelável, impessoal, binário e dicotômico entre brancos e pretos, inferiores e superiores, dominantes e dominados etc" (Da Matta, 1983:150).

Dessa forma, evidencia-se a dificuldade da sociedade brasileira para lidar com sistemas e princípios igualitários e universalizantes, e se empobrece o sentido da cidadania entre nós.

A sociedade brasileira, assim, se representa a si mesma através da cordialidade, onde a ideologia da intimidade, do favor e do jeitinho predomina. Daí que, segundo Da Matta (1983), as relações pessoais formam o núcleo da sociabilidade, em contraste com o domínio das normas e leis, quer dizer, das relações impessoais. Os diversos paradoxos e ambigüidades da cultura brasileira, revelam que as relações cotidianas, tão marcadas por valores como consideração, intimidade, favor, etc, se acompanham de conflito e de autoritarismo. Subjaz a estas relações sociais, na verdade, um apego às posições hierárquicas e aos sistemas de identificação social o que torna possível recriar múltiplas hierarquizações e formas de exclusão.

Assim, em sociedades de forte hierarquização, como a brasileira, onde ainda é bastante gritante a presença de um contingente considerável de população excluída da cidadania, são inúmeras as dificuldades para se avançar na representação da igualdade e na construção da esfe- res publica

conflito e confronto

relaçöes pessoais $x$ normas e leis 
grau de regulamentação $\mathrm{x}$ impacto das leis

justiça social

impulsos corporativos ra pública. Uma conseqüência dessa realidade quase inevitável diz respeito à peculiar presença do Estado no Brasil, e ao aparentemente alto grau de regulamentação das mais diversas esferas do mundo da vida e das atividades produtivas. Ao mesmo tempo, o Estado brasileiro demonstra sua fraqueza colossal, em virtude do baixo impacto das leis, da existência de leis que pegam e que não pegam. O Estado parece incapaz de implementar, fiscalizar e punir, de fazer a lei ser respeitada e acatada.

$\mathrm{Na}$ verdade, o Estado brasileiro possui baixa eficácia e eficiência, com capacidade quase nula de enforcement, isto é, de fazer com que suas decisões sejam implementadas e acatadas, de evitar a impunidade dos infratores. E sofre toda sorte de pressão, tendo que ceder aos grupos politicamente mais fortes. As elites políticas dominantes utilizam o Estado e as leis de acordo com seus interesses, fazendo como que os limites entre o público e o privado sejam transgredidos a todo momento. Nesse sentido, o Estado deixa de ser o locus da autoridade e o pólo aglutinador do consenso social e da solidariedade. E não cumpre o seu papel fundamental, o de zelar pelos interesses públicos e pela administração da justiça social.

Aliás, justiça social, convém esclarecer, significa que o Estado e as instituições governamentais estão empenhados em assegurar um padrão, uma estrutura básica de direitos, em cada sociedade, para o conjunto da cidadania (Rawls, 1971:9). Essas estruturas básicas operam no sentido de que um conjunto de desigualdades sejam consideradas arbitrárias e, portanto, injustas, a não ser que resultem em benefício para todos. Assim, parece adequado, neste caso, sacrificar interesses individuais em benefício do bem público e do interesse geral. É o caso de se ter em mente que interesses e reivindicações de uma categoria social politicamente forte são capazes de influir, decisivamente, na formulação e na reorientação de determinadas políticas públicas, que resultam, quase sempre, em prejuízo da coletividade como um todo. Neste caso, buscam-se privilégios e prebendas, sem qualquer sentido de justiça distributiva ou de conquista de princípios de justiça social.

Os impulsos corporativos e de procura de novos e crescentes privilégios para categorias restritas, freqüentemente encontram respaldo nas estruturas de poder dos estados modernos e nas arenas decisórias onde as políticas públicas são implementadas. Os grupos de interesses corporativos não só expressam demandas nas arenas decisórias, como participam destas arenas, implementando políticas e substituindo funções tradicionalmente afeitas aos partidos políticos, e ao próprio governo. Isso significa, na prática, a privatização do espaço e dos interesses públicos. Os arranjos corporativos têm participação decisiva nos espaços decisó- 
rios governamentais e, portanto, na definição e na implementação das políticas de cunho social. Assim, leva-se ao extremo o monopólio da representação dos interesses setoriais, aumenta a distância entre sociedade civil e Estado, e se impede a implementação de políticas redistributivas, como no caso, por exemplo, da saúde e da educação.

No Brasil, diante das imensas distâncias que marcam nossa estrutura social, e implicam o monopólio do poder pelas elites dirigentes, o Estado, em que pese sua democratização relativamente recente, tem enorme dificuldade em promover a cidadania e garantir direitos universais. A dimensão do direito quase nunca aparece e, quando presente, resvala, freqüentemente, para a manutenção de privilégios e de interesses corporativos. Nesse sentido, é bom lembrar que o fortalecimento da cidadania, e os movimentos sociais que se alastraram pelo país no decorrer dos anos 80, têm uma importância histórica na reversão dessas tendências. O processo cuja culminância foi a Constituição de 1988 serve como um divisor de águas para a cidadania, no país.

A cidadania, como vimos, remete à crença na eficácia das leis e dos mecanismos institucionais, universalizantes e igualitários. No nosso caso, a permanência de características de uma sociedade fortemente hierarquizada, aliada às distorções na aplicação das leis e no funcionamento das instituições democráticas, lhe enfraquecem o significado. No processo de ruptura com o tradicional sistema de patronagem e com o coronelismo, representações políticas tão presentes entre nós, o poder público e os princípios básicos da res publica - isto é, de definição de um sistema de governo baseado na separação ética entre interesses públicos e privados -, revelam-se incapazes de promover uma nova sociabilidade, baseada na solidariedade e em um novo princípio ético.

\section{Cidadania e movimentos de defesa do consumidor}

Desde o fim da ditadura no Brasil, e a partir da consolidação da democracia entre nós, são inúmeras as demonstraçōes da vitalidade e da presença dos movimentos da sociedade civil e de defesa da cidadania. O dinamismo desta sociedade pode ser atestado pela proliferação dos movimentos de bairro e das associações de moradores, contra a carestia e o custo de vida, para não falar dos movimentos feministas, dos homossexuais, dos negros, dos índios, dos aposentados etc. No caso da saúde, inúmeros movimentos surgiram em torno das precárias condições de moradia e saneamento, e do acesso a serviços públicos de saúde. Outros movimentos deram origem a associações que se organizam e defendem os direitos dos diabéticos, dos portadores de deficiência física, dos HIV positivos, em um processo contínuo de invenção de direitos universais 
atores

Instituto Brasileiro de Defesa do Consumidor

Código de Proteção e Defesa do Consumidor

autocontrole e controle externo novos sujeitos coletivos e de novos direitos. Todo esse conjunto representa um processo legítimo de constituição de atores - reveladores da complexidade de interesses presentes na sociedade brasileira atual -, que se organizam em defesa de determinadas reivindicações e demandas, e buscam diálogo com o poder público.

Um bom exemplo desses movimentos é a criação de órgãos de defesa dos direitos do consumidor. Esses órgãos representam, indubitavelmente, um antídoto contra a privatização do espaço público e contra os interesses corporativos, muitas vezes encastelados no Estado e no setor público como um todo. O Instituto Brasileiro de Defesa do Consumidor (IDEC) é uma entidade não-governamental que, junto com outras tantas organizações civis, é fundamental para a afirmação dos direitos da cidadania no país. O objetivo do IDEC é informar e defender o consumidor diante da justiça, realizar pesquisas e testes de produtos visando o estabelecimento de padrões de qualidade; promover, enfim, política e legislação de interesse do consumidor, com a criação de grupos de cidadãos preocupados com a defesa do consumidor (Silver, 1992).

O Código de Proteção e Defesa do Consumidor, lançado em 1990, significa, sem dúvida, uma grande transformação nas relações entre consumidores (o público em geral) e empresas de produtos e serviços. E evidencia a incapacidade do mercado, por si só, proteger e garantir os direitos do consumidor. Ao contrário, atesta que a pura lógica do mercado e da produção amiúde descuida da segurança e da saúde dos cidadãos.

O Código atua, assim, no sentido de estabelecer claramente, para efeitos legais, os direitos básicos do consumidor. Atribui responsabilidade ao fabricante, ao fornecedor, ao produtor, ao construtor pela reparação de danos causados aos consumidores, e estabelece, inclusive, infrações penais. Desde a promulgação do Código, a Vigilância Sanitária desempenha um papel essencial de articulação e de interlocução entre governo e sociedade civil, e passa a acrescentar às suas funções o aspecto educativo e preventivo. A afirmação dos direitos dos consumidores e, por extensão, de toda a cidadania inclui o direito de obter informação acerca dos riscos à saúde decorrentes do consumo de produtos e serviços. Isto é, o Estado pauta sua intervenção em duas frentes, atuando quer no controle e na regulamentação do processo de produção de bens e serviços, quer na proteção ao direito básico do consumidor (Eduardo, 1998).

Além disso, segundo Maria Eduardo, o Código de Defesa do Consumidor traz duas inovações conceituais importantes. A primeira se refere à concepção de autocontrole, na medida em que o produtor deve ser responsável pela qualidade daquilo que produz. De outro lado, traz a idéia de controle externo, cabendo ao poder público, e à sociedade 
como um todo, a defesa e a vigilância da qualidade de bens e produtos postos à disposição dos consumidores. Nessa medida, reforça o papel da Vigilância Sanitária na elaboração de normas, no licenciamento dos estabelecimentos, na fiscalização, na aplicação de medidas, na orientação e educação, visando a proteção da saúde da população (Eduardo, 1998). De qualquer forma, convém acentuar que, do ponto de vista das políticas públicas e da gestão do sistema, a Vigilância Sanitária pressupõe independência administrativa e autonomia financeira e, ao mesmo tempo, uma interlocução permanente com os diversos órgãos da sociedade civil.

Várias entidades e movimentos emergem, nesse contexto, em defesa dos direitos da cidadania e dos consumidores, da saúde e do meio ambiente, numa demonstração clara do potencial de transformação dos movimentos sociais e das chamadas Organizações não Governamentais (ONG). O próprio IDEC, entre outros organismos, trava uma luta permanente pela implantação e pelo cumprimento do Código de Defesa do Consumidor, assim como os PROCONs.

Porém, como em outras áreas e setores, o Brasil sofre do paradoxo de apresentar uma legislação atualizada e favorável ao consumidor, porém de aplicabilidade muito baixa. E essa realidade aumenta o grau de descrença da população nos dispositivos legais. Aqui, como em outras esferas da sociedade brasileira, a distância entre lei e prática social é enorme. De qualquer forma o caminho continua sendo o de fortalecimento da sociedade civil, dos movimentos sociais, em geral, e dos órgãos de defesa do consumidor, em particular.

\section{Considerações finais}

Segundo os princípios da Constituição de 1988, que estabeleceu ser a saúde um direito de todos, e dever do Estado, a universalização e a operacionalização deste direito, dependem da criação do Sistema Único de Saúde (SUS). A Constituição propõe um novo modelo de organização da atenção e uma nova lógica de financiamento do setor saúde no país. Os modelos ou sistemas de saúde universalistas, comumente, são financiados com os impostos gerais, e não através de impostos ou contribuições de categorias, ou de grupos específicos de trabalhadores. São Sistemas Únicos, ou Unificados, no sentido de serem respaldados por um modelo de financiamento decidido centralmente (pelo governo federal), apesar de suas ações e serviços serem executados de forma descentralizada, através de estados e municípios. A operacionalização do SUS envolveu, desde seu início, a implementação de outros princípios reformistas
PROCONS

Sistema Único de Saúde 
descentralização/municipalização

relação público/privado mais afeitos ao chamado modelo assistencial em saúde: regionalização, hierarquização e integralidade dos serviços médico-sanitários vis-à-vis a descentralização e a participação social.

Sem dúvida, o SUS aparece como um contraponto crítico ao modelo até então vigente de políticas sociais e de saúde no Brasil, pois foi pensado como um modelo alternativo, voltado para a superação do caráter altamente centralizado, burocratizado, privatista e excludente das políticas públicas. A perspectiva da descentralização/municipalização aparece, nesse contexto, como um instrumento adequado para o uso e a reçistribuição mais eficiente dos escassos orçamentos públicos e para a busca de maior eficiência e resolutividade dos serviços prestados. Reivindicam-se a descentralização das políticas sociais e de saúde, visando uma completa democratização das instituições e a diminuição da distância entre centros decisórios e cidadãos. Nesse sentido, em tese, a descentralização significa a possibilidade de implementação de políticas sociais segundo a lógica da eqüidade, com a ampliação do direito e do acesso a serviços e bens. E permite a participação dos cidadãos na gestão pública e potencializa os instrumentos de fiscalização e de alocação dos gastos públicos.

O contexto atual de reforma do Estado, e o conjunto de restrições advindas da política de ajuste econômico, mostra-se, paradoxalmente, favorável à retomada do debate sobre a relação público/privado e sobre a descentralização, no âmbito das políticas sociais. O processo de descentralização, indubitavelmente, aparece como um rumo novo e desejável na política de saúde, caminho possível de implantação do SUS e campo fértil para inovações na gestão do sistema de saúde. Sem dúvida, o deslocamento da arena decisória para os níveis estaduais e municipais, consumada na última década - e com o fortalecimento, em especial, do nível municipal -, representa um enorme desafio técnico e gerencial. A questão central é grande parte dos municípios brasileiros depender, ainda hoje, dos repasses federais do SUS para a organização de sua rede e para o funcionamento dos seus serviços de saúde. Em termos de financiamento do sistema, no geral, os estados gastam com a saúde, em média, de $6 \%$ a $8 \%$ do que arrecadam, sendo que $80 \%$, em média, destes recursos se destinam ao pagamento de pessoal. Já os municípios investem aproximadamente entre $9 \%$ a $11 \%$ do total arrecadado. Uma arrecadação maior não significa, necessariamente, um investimento maior no setor saúde, já que não foi ainda aprovado o projeto de lei que vincula parte da arrecadação da união, dos estados e dos municípios a gastos e investimentos no setor saúde.

É necessário destacar a importância que terá, na efetiva municipalização do setor saúde, no país, a implementação, pelo Ministério da 
Saúde, do chamado Piso Assistencial Básico (PAB), cujo objetivo é mudar a lógica de repasse e de distribuição dos recursos do SUS para os municípios. É bem conhecido que, até então, tais repasses se calculavam com base na quantidade de procedimentos realizados por cada unidade de atendimento local. Isto é, quanto maior o número de ações médico-assistenciais realizadas e apresentadas ao Ministério da Saúde, mais recursos são repassados pelo SUS, respeitando-se um certo limite (teto financeiro global). O PAB altera essa lógica, naquilo que é compreendido pelo Ministério da Saúde como procedimentos básicos, propondo para todos os municípios da união, uma alocação de recursos segundo o referencial da população existente em cada município. Inverte-se o princípio do governo federal pagar pela quantidade de procedimentos médico-sanitários realizados. O sistema inaugura o repasse fundo a fundo, baseado em um valor per capita. A questão é que, independente do valor fixado, o $\mathrm{PAB}$, em princípio, opera pela lógica da eqüidade: quanto maior a população do município, maior o repasse. O repasse do SUS, portanto, não dependerá mais da capacidade instalada (rede de serviços de saúde) de cada município.

Assim, municípios pobres, com infra-estrutura de serviços precária, ou praticamente inexistente - a maioria dos municípios brasileiros - receberão uma quantidade de recursos ligeiramente maior, considerando-se a situação até então existente. Por um lado, deve-se prestar atenção ao caráter distributivo da proposta do PAB - já que tende a beneficiar municípios e populações até então excluídos dos cuidados e ações primárias em saúde. E, por outro, na necessidade de haver fiscalização na utilização dos novos recursos recebidos pelos municípios. Como os repasses do PAB são automáticos e regulares, e depositados em contas específicas nos municípios habilitados ${ }^{2}$, acabam com uma série de intermediações e mecanismos de negociação das verbas do SUS.

O novo sistema por si só, como se sabe, não é garantia de maior investimento em saúde, mesmo nos municípios contemplados com um volume maior de recursos. São necessárias novas formas de acompanhamento e de controle dos gastos, para se garantir, de fato, o fim do
Piso Assistencial Básico

\footnotetext{
2 Os municípios, para receber o $\mathrm{PAB}$, em princípio, devem requerer sua habilitação e atender a uma das condiçōes de gestão estabelecidas na NOB SUS 01/96. O processo é então encaminhado à Comissão bipartite de cada Estado. Os municípios precisam comprovar a existência de Fundo Municipal de Saú. de, de Conselho Municipal de Saúde (CMS); de Plano Municipal de Saúde (PMS); de capacidade técnica e administrativa para arcar com as responsabilidades de contratação, pagamento, controle e auditoria dos serviços sob sua gestão; de médico responsável pela autorização prévia, pelo controle e pela auditoria de procedimentos e serviços realizados; de capacidade para desenvolver ações de Vigilância Sanitária e de Vigilância Epidemiológica; de disponibilidade de estrutura de recursos humanos para a supervisão e a auditoria da rede de unidades, dos profissionais e dos serviços realizados (Brasil, 1998).
} 


\section{fiscalização e controle sanitário de produtos, serviços e ambientes}

\section{sistema gerencial ágil} e eficiente

ética da responsabilidade desvio de verbas e a prioridade nos investimentos em ações preventivas e básicas.

Um outro ponto a ser esclarecido é que o PAB, além dessa parte fixa, é composto de uma parte variável, onde se incluem algumas atividades definidas como especiais pelo Ministério da Saúde: Programa de Agentes Comunitários de Saúde (PACS); Programa de Saúde da Família (PSF); assistência farmacêutica básica; programa de combate às carências nutricionais; ações de Vigilância Sanitária e, finalmente, ações de Vigilância Epidemiológica e ambiental. As ações de Vigilância Sanitária compreendem fiscalização e controle sanitário de produtos, serviços e ambientes e atividades de educação em Vigilância Sanitária.

O ponto central da discussão e dos debates sobre o perfil das políticas de saúde no país - no sentido da construção de um sistema público de saúde capaz de garantir universalidade, e eqüidade, e de incentivar uma mudança radical no conjunto das práticas de saúde -, é a redefinição gerencial e a recapacitação técnica dos quadros profissionais do setor, mais do que a ausência ou a escassez de recursos financeiros. Trata-se da implantação de um sistema gerencial ágil e eficiente em todos os níveis da administração pública mas, em particular, nos municípios mais afastados dos grandes centros.

É necessário, sem dúvida, aliar uma maior capacidade técnicogerencial a vontade política, compromisso social e respeito ao poder público. As experiências de acompanhamento e avaliação da municipalização em saúde têm mostrado ser comum o poder político local estar bem intencionado e ter disposição para investir no setor saúde mas estar tecnicamente despreparado. O contrário também acontece, pois há municípios com uma considerável estrutura física, técnica e de recursos humanos no setor saúde, que não incluem o setor saúde como prioridade na agenda pública local. Nos dois casos as mudanças são difíceis.

Convém chamar a atenção para o aspecto ético-político que envolve o exercício da autoridade política, o papel do profissional e do funcionário público, e tornam cada vez mais importante a introdução de uma ética da responsabilidade. Esta ética se define não só pela preocupação em adequar meios e fins, mas também pela busca da eficácia, ou seja, pela procura dos meios mais adequados aos objetivos pretendidos. Assim, compreende a questão dos valores e da responsabilidade pelas conseqüências que envolvem a ação da autoridade e do profissional, na função pública. 


\section{Referências bibliográficas básicas}

BECK, Ulrich, 1997. Modernização reflexiva. (Politica, Tradição e Estética na Ordem Social Moderna). São Paulo: Editora da Universidade Estadual Paulista.

BOBBIO, Norberto, 1988. Liberalismo e Democracia. São Paulo: Brasiliense.

BODSTEIN, Regina Cele de A., 1995. Cidadania e Direitos Sociais: Dilemas da Questão Social. [Tese de Doutorado - Escola Nacional de Saúde Pública - FIOCRUZ - Rio de Janeiro].

BODSTEIN, Regina Cele de A., 1997. Cidadania e Modernidade: emergência da questão social na agenda pública. Cadernos de Saúde Pública, Rio de Janeiro, 13(2):185-204, abr-junho.

DAHRENDORF, Ralf, 1997. Após 1989 (Moral, Revolução e Sociedade Civil). Rio de Janeiro: Paz e Terra.

DA MATTA, Roberto, 1983. Carnavais, Malandros e Heróis (Para uma Sociologia do Dilema Brasileiro). Rio de Janeiro: Zahar, 4a Edição.

DUMONT, Louis, 1993. O Individualismo: Uma Perspectiva Antropológica da Ideologia Moderna. Rio de Janeiro: Rocco.

ELIAS, Norbert, 1990. Processo Civilizador (Uma História dos Costumes), v. 1. Rio de Janeiro: Jorge Zahar.

LEFORT, Claude, 1991. Pensando o Político (Ensaios sobre Democracia, Revolução e Liberdade). São Paulo: Paz e Terra.

GIDDENS, Anthony, 1991. As Conseqüências da Modernidade. São Paulo: Editora da Universidade Estadual Paulista.

MARShalL, T. H., 1967. Cidadania, Classe Social e Status. Rio de Janeiro: Zahar.

SILVER, Lynn, 1992. Os Movimentos de Defesa do Consumidor: Cidadão e Saúde. Saúde para Debate (Divulgação 7) (pp. 41-47), maio.

\section{Referências bibliográficas complementares}

ARENDT, Hannah, 1971. Sobre a Revolução. Lisboa: Moraes Editores. 1972. Entre o Passado e o Futuro. São Paulo: Perspectiva, 2a Edição. 1989. A Condição Humana. Rio de Janeiro: Forense Universitária.

BOBBIO, Norberto, 1987. O Futuro da Democracia (Uma Defesa das Regras do Jogo). Rio de Janeiro: Paz e Terra, 3a Edição.

BRASIL, Ministério da Saúde, 1998. O Que Muda com o PAB? Brasília.

CASSIRER, Ernst, 1992. A Filosofia do Iluminismo. Campinas: Editora da Universidade de Campinas.

DE SWAAN, Abraan, 1988. In Care of the State: Health Care, Educacion in USA in the Modern Era. London: Polity Press.

EDUARDO, Maria B., 1998. O Modelo de Vigilância Sanitária e a Defesa da Cidadania. Revista de Administração Pública. Rio de Janeiro. 32 (2):147-65, mar/abr.

ELIAS, Nobert, 1993. Processo Civilizador (Formação do Estado e Civilização), v. 2, Rio de Janeiro: Jorge Zahar. 1994. A Sociedade dos Individuos. Rio de Janeiro: Jorge Zahar.

LEFORT, Claude, 1989. Em Torno do Marxismo. (Entrevistas no Le Monde). São Paulo: Ática,

RAWLS, John, 1971. Theory of justice. Cambridge Mass. 



\section{A Vigilância Sanitária, segundo as normas operacionais básicas do Ministério da Saúde}

Patricia T. R. Lucchese

\section{Histórico}

A descentralização da atenção à saúde, no âmbito do Sistema Único de Saúde, foi desencadeada a partir de 1991. Deu-se imediatamente após o ordenamento jurídico, complementar à Constituição, destinado a regular em todo o território nacional as açōes e serviços de saúde - a Lei n 8.080 de 19 de setembro de 1990 e a Lei ne 8142 , de 28 de dezembro de 1990 .

Desde então, o Ministério da Saúde vem utilizando, como instrumento normativo para operacionalizar a descentralização do sistema, em especial no que diz respeito à gestão descentralizada da assistência médica, ambulatorial e hospitalar, normas operacionais básicas, publicadas no Diário Oficial da União. Essas normas são editadas na medida em que o processo de descentralização das ações e serviços de saúde impõe aperfeiçoamentos e inovações.

No período de 1991/1998 se publicaram quatro Normas Operacionais Básicas (NOB): a NOB 01/91, a NOB 01/92, a NOB SUS 01/93 e a NOB SUS 01/96. Cada uma introduziu mudanças importantes - e muitas vezes polêmicas - na organização da gestão das ações e serviços e, principalmente, na operacionalização das relações político-institucionais e financeiras entre as três esferas de governo.

A partir da edição da NOB SUS 01/93 este instrumento normativo passa a ser identificado como um instrumento político relevante. Não apenas por corresponder à síntese de negociações e pactos entre os três niveis gestores do SUS mas, principalmente, por respeitar a estratégia de descentralização discutida, e aprovada, nas Conferências Nacionais de Saúde e no Conselho Nacional de Saúde (CNS). descentralização 
NOB SUS $01 / 93$

Comissão Intergestores

Tripartite, Conselho Nacional de Saúde
A formulação das normas operacionais a partir da NOB SUS 01/93: um processo dinâmico e participativo

É possível caracterizar o processo de formulação das NOBs como dinâmico e participativo, e bastante permeável à diversidade de demandas dos diferentes atores setoriais. O fórum privilegiado de discussão técnica e de negociação política é a Comissão Intergestores Tripartite (CIT), composta por 5 representantes do Ministério da Saúde, 5 representantes do Conselho Nacional de Secretários Municipais de Saúde (CONASEMS) e 5 representantes do Conselho Nacional de Secretários Estaduais de Saúde (CONASS). O Conselho Nacional de Saúde atua como instância de discussão e de aprovação final das NOBs, para publicação de portaria ministerial no Diário Oficial da União e posterior implementação.

A NOB SUS 01/93 correspondeu à tradução operacional da estratégia política de descentralização aprovada na IX Conferência Nacional de Saúde, detalhada no documento oficial - A Descentralização das Ações e Serviços de Saúde: a Ousadia de Cumprir e Fazer Cumprir a Lei. Este documento, elaborado e largamente divulgado pela direção do Ministério da Saúde, constituiu a referência básica para um longo processo de discussão e negociação com os vários atores setoriais no âmbito da Comissão Intergestores Tripartite e do Conselho Nacional de Saúde. Estes órgãos analisaram as contribuições e críticas encaminhadas ao Ministério da Saúde pelas Secretarias Estaduais e Municipais de Saúde, pelo setor privado, por entidades de representação popular e sindical, por instituições públicas federais e por entidades científicas; essas contribuições foram incorporadas, muitas vezes, ao documento.

Estabelecido o pacto na Comissão Intergestores Tripartite, e aprovada a versão final do documento, pelo Conselho Nacional de Saúde, o conteúdo do mesmo foi traduzido operacionalmente. E a resultante Norma Operacional Básica SUS 01/93 foi publicada no Diário Oficial da União (Portaria MS n 545, de 20 de maio de 1993), disciplinando os procedimentos reguladores da implementação da descentralização das ações e serviços de saúde no país.

A NOB SUS 01/93, ainda que procurasse contemplar todas as ações e serviços do Sistema Único de Saúde, restringiu-se às atividades ambulatoriais e hospitalares, que já trilhavam uma trajetória de descentralização no âmbito do Inamps. As demais áreas, como as ações de saúde coletiva, de Vigilância Sanitária, de vigilância nutricional e de medicamentos, encontravam-se, ainda, num estágio inicial de discussão. E, assim, não lograram apresentar propostas operacionais, a tempo de se incluírem, na versão publicada da norma, as redefinições das atribui- 
ções das três esferas de governo e os mecanismos de financiamento das mudanças. Estabeleceu-se o prazo de 90 dias para elaboração e publicação de normas complementares, que, no entanto, não ocorreu.

Assim, a estratégia operacionalizada através da NOB SUS 01/93 se implementou, apenas, para as assistências ambulatorial e hospitalar. E, vale dizer, de forma parcial, dados os inúmeros constrangimentos financeiros, políticos e administrativos a afetarem a gestão ministerial, na conjuntura. A estratégia de descentralização da Vigilância Sanitária só adquiriu contornos um pouco mais claros no âmbito da NOB SUS 01/96, como veremos adiante.

A formulação da NOB SUS 01/96, publicada no Diário Oficial da União, em 6 de novembro de 1996 (Portaria ne 2.203, de 5 de novembro de 1996), seguiu o processo amplo e participativo de formulação da norma anterior, embora diferenciado da mesma.

Em primeiro lugar, a NOB 01/96 surgiu como demanda, dos gestores federal, estaduais e municipais, de aperfeiçoamento da operacionalização da descentralização, como resultado dos Encontros Macroregionais da Secretaria de Assistência à Saúde do Ministério da Saúde (SAS/ MS) com as Comissões Intergestores Bipartite (CIB), de praticamente todos os estados brasileiros, ao longo do ano de 1995. Nestes Encontros deram-se três etapas de reuniōes, com compromissos e tarefas definidos, para se estabelecerem as bases de uma programação pactuada e integrada da assistência ambulatorial e hospitalar, entre as instâncias federal, estadual e municipal de governo. A avaliação dos Encontros constatou a urgência de se avançar a descentralização das ações de epidemiologia e controle de doenças, e as de Vigilância Sanitária, para efetivar-se a implantação do Sistema Único de Saúde. A idéia de uma nova Norma Operacional (NOB SUS 01/96), portanto, surge como demanda de aperfeiçoamento do instrumento normativo vigente naquele momento - a NOB SUS 01/93, não sendo precedida pela discussão de uma estratégia política, geral, de reorientação. Assim, todo o processo de negociação, ainda que orientado politicamente, adquiriu um caráter predominantemente técnico.

Pode-se afirmar, também, em segundo lugar, que o processo de formulação da NOB SUS 01/96 se diferencia do anterior porque, ao enfatizar a organização do modelo assistencial do SUS, promoveu o diálogo entre as diferentes áreas do Ministério da Saúde, até então completamente desarticuladas e sem comunicação. A pressão dos gestores estaduais e municipais por definições, e a disposição da gestão ministerial de investir em um novo modelo de atenção à saúde no país, concorreram para a aproximação entre as áreas de saúde coletiva e as de atenção individual. Assim, se desenharam novas configurações para a ges- assistências ambulatorial e hospitalar

NOB SUS 01/96

Comissões Intergestores Bipartite (CIB)

aproximação entre saúde coletiva e atenção individual 
tão descentralizada da Vigilância Sanitária e das ações de epidemiologia e de controle de doenças.

Em terceiro lugar, merece destaque a participação ativa e sistemática do Conselho Nacional de Saúde, que acompanhou e influiu, detalhadamente, nas várias versões do documento, durante toda a elaboração da Norma, numa demonstração da relevância e do amadurecimento da participação dos diferentes atores setoriais no direcionamento da política de saúde.

E, por fim, diferentemente do processo anterior, a NOB SUS 01/96 não nasceu em conseqüência de uma Conferência Nacional de Saúde, como a NOB 93 nasceu da IX CNS. Ao contrário, esta norma foi encaminhada à X Conferência após publicação de versão para consulta pública, no Diário Oficial da União, com o intuito de se recolherem avaliações críticas e sugestões para análise e aprovação final do Conselho Nacional de Saúde, após a realização da Conferência.

Assim, parece lícito afirmar que a formulação das NOBs vem apresentando um caráter bastante dinâmico, participativo e flexível, potencialmente sensível aos diversos interesses de diferentes atores, e adaptável às oscilações da conjuntura no setor saúde. Esse caráter pode ser apontado como um dos aspectos a favorecerem a legitimidade e a implementação gradativa das inovações.

\section{A implementação das NOBs: processo gradativo e incompleto}

A implementação das NOBs, como processo operacional inscrito na realidade social, sofre constrangimentos das mais variadas naturezas: econômica, política, institucional, jurídica, administrativa e cultural. Portanto, a implementação da norma é sempre incompleta.

Um dos aspectos mais importantes no processo de implementação das NOBs é o mecanismo previsto para o exercício da negociação e do pacto entre os três gestores do sistema. As Comissões Intergestores Tripartite, na esfera federal (CIT), e Bipartite, na esfera estadual (CIB) - desempenham um papel fundamental na medida em que identificam as especificidades regionais, estaduais e municipais e viabilizam o exercício da negociação e do pacto. Tudo o que diga respeito à descentralização dos procedimentos necessários para a implementação da gestão descentralizada do SUS é amplamente discutido, tecnicamente analisado e negociado politicamente nestes fóruns.

A NOB SUS 01/93 previa duas condições de gestão descentralizada do sistema, para os Estados (parcial e semiplena), e três condições de gestão, para os municípios (incipiente, parcial e semiplena). Condições estabelecidas segundo responsabilidades, prerrogativas e mecanismos 
de financiamento, que o gestor se dispunha a assumir, segundo sua vontade política e as condiçōes técnicas e materiais, com a aprovação do respectivo Conselho de Saúde. ${ }^{1}$

Publicada a norma em maio de 1993, somente em agosto de 1994 as condições jurídico-administrativas para a operacionalização dos repasses financeiros, da esfera federal para as esferas estadual e municipal, via transferência fundo a fundo, a fim de viabilizar as condições de gestão parcial e semiplena, ganharam regulamentação (Decreto n 1.232 , de 30 de agosto, da Presidência da República). No entanto, em função da disponibilidade de recursos financeiros no Fundo Nacional de Saúde, só foi possível efetivar os repasses financeiros para a gestão semiplena de municípios.

Independentemente da inexistência de recursos para as demais condições de gestão, estados e municípios aderiram à sistemática e se mobilizaram para o cumprimento dos requisitos previstos para a condição que se propuseram desenvolver, habilitando-se a implantar a gestão descentralizada do sistema. Assim, em janeiro de 1997, o país já contava com 2.367 municípios habilitados à gestão incipiente, 616 à gestão parcial e 144 a operar efetivamente a gestão semiplena (11 capitais); esses números correspondiam a $63 \%$ do total de municípios brasileiros. Quanto aos estados, 9 habilitaram-se à gestão parcial e 7 à gestão semiplena. ${ }^{2}$

Vale registrar que nos municípios em gestão semiplena residiam $17 \%$ da população brasileira e para esses municípios se transferiam, direta e automaticamente, $25 \%$ dos recursos federais para assistência médica ambulatorial e hospitalar. ${ }^{3}$

A NOB SUS 01/96, publicada em novembro de 1996, no período de interinidade do Ministro José Carlos Seixas, em plena transição da gestão de Adib Jatene à de Carlos Albuquerque, no Ministério da Saúde, foi objeto de discussão durante praticamente todo o ano de 1997, em repasses financeiros

\footnotetext{
${ }^{1}$ Sobre os conteúdos, instrumentos e fluxos (etapas e trâmites) do processo de habilitação às diferentes condições de gestão da NOB 93, inclusive definiçōes quanto à participação das diferentes instâncias (Secretarias de Saúde, Conselhos de Saúde e Comissões Intergestores) no processo decisório sobre a habilitação, ver Instrução Normativa ne 01/93, de 23/09/93, publicada no Diário Oficial da União em 7/10/93.

2 Fonte: Banco de Dados de Habilitação da Coordenação Geral de Desenvolvimento e Avaliação de Serviços de Saúde (CGAS) do Departamento de Assistência e Promoção à Saúde (DAPS) da Secretaria de Assistência à Saúde (SAS) do Ministério da Saúde.

${ }^{3}$ Para uma descrição detalhada do processo de formulação e implementação da NOB SUS 01/93, ver LUCCHESE, P.T.R. Descentralização do Financiamento e Gestão da Assistência à Saúde no Brasil: a Implementação do Sistema Único de Saúde - Retrospectiva 1990/1995, In: Planejamento e Politicas Públicas. Brasília: IPEA, no 14, dezembro, 1996.
} 
novas práticas de gerência virtude da necessidade de esclarecimentos e detalhamento das inovações previstas no âmbito da nova conjuntura ministerial; essa realidade adiou a implementação efetiva da norma para 1998.

A NOB 96 prevê duas condições de gestão descentralizada, para os estados (gestão avançada do sistema estadual e gestão plena do sistema estadual) e duas para os municípios (gestão plena da atenção básica e gestão plena do sistema municipal), estabelecidas, também, com base em responsabilidades, prerrogativas e mecanismos de financiamento. ${ }^{4}$

Ressalte-se que a implementação da NOB 96 vem apresentando ritmo bem mais rápido do que o da NOB 93. Pouco antes de completar dois anos de publicação, em setembro de 1998, 4.395 municípios, isto é, $80 \%$ do total estavam em processo de implantação da condição de gestão plena da atenção básica e $441(8 \%)$ a gestão plena do sistema municipal. E já recebiam, direta e automaticamente, recursos financeiros previstos para isso; ou seja, $88 \%$ do total de municípios já haviam aderido à nova sistemática. ${ }^{5}$

Quanto aos estados, em outubro de 1998, Alagoas implantava a gestão plena de sistema e o Distrito Federal implantava a gestão avançada. Rio Grande do Sul, São Paulo e Bahia estavam habilitados à condição de gestão avançada de sistema, e Minas Gerais à gestão plena de sistema, e aguardavam homologação pelo Ministério da Saúde, para implantação da condição.

Tais dados expressam o fato de vir o processo de descentralização adquirindo agilidade, com a consolidação de novas práticas de gerência e de relacionamento entre as três esferas de governo, e com a redefinição do fluxo de decisão na gestão do sistema.

Existe um conjunto significativo de documentos oficiais, de algumas pesquisas de opinião e de informações sistematizadas sobre o processo de descentralizacão nos últimos anos ${ }^{6}$. bem como de estudos bas-

\footnotetext{
${ }^{4}$ Sobre as responsabilidades, prerrogativas e requisitos das diferentes condições de gestão ver itens 15 e 16 da NOB SUS 01/96 - Condições de Gestão do Município e Condições de Gestão do Estado, respectivamente. Sobre o processo de habilitação ver Instrução Normativa n² 01/98, de 2 de janeiro de 1998 , publicada no Diário Oficial de 06/01/98.

5 Fonte: Ministério da Saúde (www.saude.gov.br).

${ }^{6}$ Desde 1995, o Ministério da Saúde, especialmente a Secretaria de Assistência à Saúde vem avaliando a gestão descentralizada da atenção ambulatorial e hospitalar do SUS, e produzindo relatórios com informaçōes estratégicas sobre estados e municípios. Da mesma forma, a Secretaria de Controle Interno do Ministério da Saúde (CISET/MS), tem desenvolvido um trabalho permanente de auditoria operacional, através do qual vem avaliando a gestão semiplena nos municípios e produzindo informações relevantes, consolidadas em relatórios. Além disso, realizaram-se duas pesquisas de opinião sobre a gestão descentralizada - Pesquisa UNICEF/GALLUP e Pesquisa CONASS/IBOPE. E por fim, os sites do Ministério da Saúde, do CONASS e do CONASEMS na Internet apresentam informações atualizadas sobre o processo de descentralização.
} 
tante relevantes que evidenciam áreas bem sucedidas e alguns nós críti$\cos .^{7}$ No entanto, ainda está por se fazer uma avaliação mais abrangente e detalhada sobre o que a habilitação e a implementação das condições de gestão descentralizada, nos estados e municípios, vem representando em termos de mudanças e resultados na ponta do sistema. Principalmente no que diz respeito às condições e organização do trabalho, à qualidade do atendimento prestado, ao acesso do cidadão às ações e serviços de saúde e à satisfação do usuário.

\section{A Vigilância Sanitária, segundo as normas operacionais básicas}

Como mencionamos anteriormente, as ações de Vigilância Sanitária receberam um tratamento extremamente superficial na Norma Operacional Básica 01/93. Isso se deu em função da imaturidade da discussão sobre a descentralização nesta área e da inexistência de propostas estruturadas naquele momento. Assim, embora haja referência à mesma na descrição das responsabilidades e dos requisitos que estados e municípios devem cumprir para poderem assumir as diferentes condições de gestão (ver Quadro 1) a essa referência não correspondem propostas para a operacionalização da Vigilância. ${ }^{8}$

Como se pode constatar, as proposições contidas na NOB 93, sem definições mais precisas sobre as características das ações básicas em Vigilância, atribuídas aos municípios, e das ações de âmbito estadual, por exemplo, refletem a ausência de um projeto para a gestão descentralizada dessas ações. Tudo indica que tais responsabilidades e requisitos não foram considerados na implantação das condições de gestão, e que tiveram impacto desconhecido na reorganização do sistema.

Menciona-se a Vigilância Sanitária, também, no item que diz respeito ao financiamento da descentralização na NOB 93. Contudo, dá-se apenas um prazo de 90 dias para se estabelecerem definições específicas para a área (item 3.5); o que não ocorreu.

\footnotetext{
7 Dentre estes, destaca-se a pesquisa A Descentralização do Sistema de Saúde no Brasil - uma Proposta de Investigação sobre o Impacto de Políticas realizada pelo Instituto de Saúde de São Paulo, com o apoio do Institutional Development Research Center/Canadá, em atendimento à solicitação da Coordenação Geral de Desenvolvimento e Avaliação de Serviços de Saúde da Secretaria de Assistência à Saúde do Ministério da Saúde, durante a gestão do Ministro Adib Jatene. O relatório da pesquisa sobre a gestão semiplena em 14 municípios de diferentes regiōes do pais, estâ disponível no site Conferência de Saúde On Line (http://www.datasus.gov.br/cns/cns.htm).

8 Ver na NOB 93 o item 4 - Das Condiçōes de Gestão.
}

NOB 93 e as açōes em Vigilância Sanitária 
Quadro 1 Responsabilidades e requisitos da área de Vigilância Sanitária - NOB SUS 01/93

\begin{tabular}{|c|c|c|c|c|}
\hline \multirow{2}{*}{$\begin{array}{l}\text { Condição } \\
\text { de gestão }\end{array}$} & \multicolumn{2}{|l|}{ Estados } & \multicolumn{2}{|l|}{ Municipios } \\
\hline & Responsabilidades & Requisitos & Responsabilidades & Requisitos \\
\hline Incipiente ${ }^{\star}$ & $x$ & $x$ & $\begin{array}{l}\text { Incorporar à rede de } \\
\text { serviços ações básicas } \\
\text { de Vigilância Sanitária } \\
\text { e desenvolver ações } \\
\text { de vigilância de ambi- } \\
\text { entes e processos de } \\
\text { trabalho. }\end{array}$ & $\begin{array}{l}\text { Manter o registro e a } \\
\text { remessa mensal de da- } \\
\text { dos para manutenção e } \\
\text { atualizaçāo dos bancos } \\
\text { de dados de registro de } \\
\text { estabelecimentos e de } \\
\text { produtos para a saúde. }\end{array}$ \\
\hline
\end{tabular}

\begin{tabular}{|c|c|c|c|c|}
\hline Parcial & $\begin{array}{l}\text { Coordenar a rede de } \\
\text { laboratórios de saúde } \\
\text { pública e assumir a } \\
\text { formulação, a execu- } \\
\text { ção e o controle das } \\
\text { ações de vigilância de } \\
\text { ambientes e processos } \\
\text { de trabalho. }\end{array}$ & $\begin{array}{l}\text { Manter o registro e a } \\
\text { remessa mensal de } \\
\text { dadós para manuten- } \\
\text { ção e atualização dos } \\
\text { bancos de dados de } \\
\text { registro de estabele- } \\
\text { cimentos e de produ- } \\
\text { tos para a saúde. }\end{array}$ & $\begin{array}{l}\text { Incorporar à rede de } \\
\text { serviços ações básicas } \\
\text { de Vigilância Sanitária } \\
\text { e assumir a formulação, } \\
\text { a execução e o controle } \\
\text { das açōes de vigilância } \\
\text { de ambientes e proces- } \\
\text { sos de trabalho. }\end{array}$ & Idem \\
\hline Semiplena & $\begin{array}{l}\text { Coordenar no seu } \\
\text { âmbito as ações de } \\
\text { Vigilância Sanitária e } \\
\text { a rede de laboratórios } \\
\text { de saúde pública. }\end{array}$ & Idem & $\begin{array}{l}\text { Assumir a execuçāo } \\
\text { e o controle das açōes } \\
\text { básicas de vigilåncia. }\end{array}$ & Idem \\
\hline
\end{tabular}

- Não há condiçăo de gestăo incipiente para os Estados.

Dessa forma, sem se apresentar um projeto claro de reorganização da gestão e sem se indicarem novas possibilidades de financiamento para a área, a Vigilância Sanitária não adquiriu centralidade na agenda política da descentralização, no âmbito da NOB 93.

É possivel afirmar que a NOB SUS 01/96, no plano mais geral, avança em relação à anterior, ao abordar a Vigilância Sanitária. Em primeiro lugar, ao referir-se ao papel do gestor federal de, entre outras ações, redimensionar a direção nacional do SUS em termos de estrutura, agilidade, integração, e de estratégias, mecanismos e articulação entre os três gestores, esta norma prevê, para a área de Vigilância Sanitária a necessidade de reorientação e implementação: 
- dos sistemas de Vigilância Sanitária, e o redimensionamento das atividades relacionadas à Vigilância Sanitária dos portos, aeroportos e fronteiras;

- dos sistemas de informações sobre a produção de serviços e insumos críticos;

- do sistema de redes de laboratórios de referência para o controle de qualidade e para a Vigilância Sanitária.

Por outro lado, ao apresentar as bases para o novo Modelo de Atenção à Saúde, a NOB 96 dá ênfase a um modelo capaz de valorizar a qualidade de vida das pessoas e o meio ambiente. E de contribuir para a construção da ética do coletivo e para a articulação com outros setores, visando a criação das condições indispensáveis à promoção, à proteção e à recuperação da saúde. Essas recomendações se associam, sem dúvida, às ações de Vigilância Sanitária e de intervenção ambiental. Da mesma forma, inclui a Vigilância entre as atividades da Programação Pactuada e Integrada, nas três esferas de governo. ${ }^{9}$

Por fim, mesmo se incorpora de forma ainda tímida, e pouco precisa, a área de Vigilância Sanitária no rol de responsabilidades das diferentes condições de gestão, a NOB 96 inova, ao prever mecanismos de financiamento para o custeio das ações da mesma, como veremos adiante.

No Quadro 2 se sintetizam as responsabilidades e os requisitos relacionados à área de Vigilância Sanitária, para cada condição de gestão na NOB 96.

Como se pode observar, na NOB 96 estão estabelecidas algumas bases para a gestão descentralizada da Vigilância Sanitária. Obedecendo ao ordenamento jurídico do SUS, descentraliza-se a execução de ações para os municípios e atribuem-se aos estados responsabilidades de caráter predominantemente regulatório, típicas do âmbito estadual - a normalização, a organização e a coordenação de ações e serviços de uma rede hierarquizada e regionalizada, a gerência de serviços de referência estadual e a cooperação técnica e financeira ao conjunto dos municípios. A atribuição dessas responsabilidades aos gestores estaduais é fundamental para a qualificação do processo de descentralização.

A responsabilidade pela execução de ações básicas, de média e/ou alta complexidade é atribuída ao estado apenas no que se refere aos municípios não-habilitados a executá-las, conforme as condições de ges-

\footnotetext{
${ }^{9}$ A Programação Pactuada e Integrada (PPI) instrumento operacional instituido pela NOB 96, é a base para a programação ascendente e negociada das atividades do sistema, para a reorganização do Modelo de Atenção e da Gestão do SUS, para a alocação de recursos e para a explicitação do pacto entre os gestores do SUS, sob acompanhamento e aprovação dos Conselhos de Saúde. Para maiores detalhes, ver item 11 da NOB SUS 01/96 - Programação, Avaliação, Controle e Auditoria.
}

novo Modelo de Atenção à Saúde

\section{Programação Pactuada e Integrada}


Condição Estados

de gestão
Responsabilidades
Requisitos

$\begin{array}{ll}\text { Gestão } & \text { - Gerência das unidades estatais da hemorede } \\ \text { avançada } & \text { e de laboratórios de referência para controle } \\ \text { do sistema } & \text { de qualidade, para Vigilância Sanitária. } \\ \text { estadual } & \text { - Normalização complementar de mecanismos } \\ & \text { e instrumentos de administração da oferta } \\ & \text { de medicamentos e insumos especiais. } \\ \text { - Cooperação técnica e financeira, com o conjunto } & \text { dos municipios, na consolidação do processo } \\ & \text { de descentralização e na organização da rede } \\ & \text { regionalizada e hierarquizada de serviços de } \\ & \text { Vigilância Sanitária. } \\ \text { - Coordenação e execução das atividades de Vigilân- } \\ \text { cia Sanitária, conforme previsto na Lei ne 8.080/90. } \\ \text { - Execução das ações básicas,de média e de alta } \\ \text { complexidade, de Vigilância Sanitária, referentes } \\ \text { aos municipios não-habilitados à execução destas } \\ \text { açōes, segundo as diferentes condições de gestão. } \\ \text { - Execução do Programa Desconcentrado de Ações } \\ \text { de Vigilância Sanitária (PDAVS)* nos termos } \\ \text { definidos pela SVS/MS. }\end{array}$

Comprovar o funcionamento do serviço de Vigilância Sanitária no estado, organizado segundo a legislação e a capacidade de desenvolvimento de ações de Vigilância Sanitária.

$\begin{array}{lll}\text { Gestão plena } & \text { Idem } & \text { Idem } \\ \text { do sistema } & & \\ \text { estadual } & \end{array}$

\section{Condiçāo Municipios}

de gestāo

$\begin{array}{ll}\text { Responsabilidades } & \text { Requisitos }\end{array}$

Gestão plena Execução das ações básicas de Vigilância

da atenção Sanitária incluidas no PBVS.

básica
Comprovar a capacidade de desenvolvimento de açōes de Vigilância Sanitária.
Gestāo plena

do sistema

municipal
Execução das açōes básicas, de média e alta complexidade, em Vigilância Sanitária, bem

como as açōes do PDAVS, opcionalmente.
Comprovar o funcionamento de serviço estruturado de Vigilância Sanitária e a capacidade para o desenvolvimento de açōes de Vigilância Sanitária.

\footnotetext{
* O PDAVS, um programa ainda não regulamentado, consiste no pagamento direto, às Secretarias Estaduais de Saúde (SES) e Secretarias Municipais de Saúde (SMS), pela prestação de serviços de competência exclusiva da Secretaria de Vigilância Sanitária do Ministério da Saúde (SVS/MS), contra a apresentaçāo de demonstrativo de atividades realizadas pela SES ao Ministério da Saúde, com base na remuneraçăo de procedimentos estabelecidos em tabela especifica.
} 
tão previstas na NOB 96. Entretanto, como não definiu as atividades e os procedimentos correspondentes aos diferentes níveis das ações e serviços de Vigilância - básicas, de média e de alta complexidade - que poderiam configurar, com mais precisão, o campo das ações municipal e estadual, no âmbito de um sistema descentralizado, a NOB 96 não viabiliza a operacionalização imediata das responsabilidades específicas previstas em cada condição de gestão.

Finalmente, no que diz respeito ao financiamento das ações de Vigilância Sanitária, a NOB 96 introduz mecanismos pouco conhecidos na área. Seguindo a orientação geral, e especialmente a configuração do custeio das assistências ambulatorial e hospitalar, estabelecem-se duas modalidades de custeio das ações, no contexto da gestão descentralizada do sistema: a transferência regular e automática de recursos, fundo a fundo, e a remuneração por serviços produzidos; esses recursos, somados, configuram o Teto Financeiro da Vigilância Sanitária (TFVS).

Para a transferência regular e automática de recursos federais diretamente do Fundo Nacional de Saúde aos fundos estaduais e municipais, dar-se-iam através de dois instrumentos operacionais: o Piso Básico de Vigilância Sanitária (PBVS) e o Índice de Valorização do Impacto em Vigilância Sanitária (IVISA). O primeiro consiste em um montante de recursos financeiros destinado ao custeio das ações básicas da Vigilância Sanitária, de responsabilidade tipicamente municipal; calcula-se esse montante a partir de um valor per capita, nacional, multiplicado pela população de cada município. A formalização do elenco de procedimentos a serem custeados pelo PBVS, bem como o valor per capita, único, para o cálculo do Piso, dar-se-á através de portaria da SVS/MS, após negociação na CIT e aprovação do Conselho Nacional de Saúde.

O IVISA consiste na atribuição de valores adicionais, equivalentes a até $2 \%$ do teto financeiro do Estado, a serem transferidos ao Fundo Estadual de Saúde como incentivo à obtenção de resultados de impacto significativo sobre as condições de vida da população, segundo critérios definidos na CIT, e fixados em portaria da SVS/MS, após aprovação do Conselho Nacional de Saúde; os estados podem transferir recursos do IVISA para os municípios, conforme definição na CIB.

Quanto à remuneração por serviços produzidos, dois outros instrumentos estão previstos: o Programa Desconcentrado de Ações de Vigilância Sanitária (PDAVS) e a remuneração de Ações de Média e Alta Complexidade em Vigilância Sanitária. O primeiro, consiste no pagamento direto, às Secretarias Estaduais de Saúde (SES) e às Secretarias Municipais de Saúde (SMS), de serviços de competência exclusiva da Secretaria de Vigilância Sanitária do Ministério da Saúde (SVS/MS); esses serviços seriam pagos contra a apresentação de demonstrativo de modalidades de custeio 
atividades, realizadas pela SES, ao Ministério da Saúde, com base na remuneração de procedimentos, definidos e valorizados em tabela específica publicada em portaria da SVS/MS, após negociação na CIT e aprovação do Conselho Nacional de Saúde. O segundo consiste no pagamento direto, às SES e SMS, pela execução de ações de alta e média complexidade, de competências estadual e municipal, dentro das mesmas condições e com a mesma sistemática descrita para o PDAVS.

Passados três anos da publicação da NOB 96, algumas Portarias Ministeriais vêm redesenhando os traços originais esboçados para o financiamento da gestão descentralizada de Vigilância Sanitária.

A Portaria ne 1.882/GM, de 18 de dezembro de 1997, extinguiu o PBVS, ao tornar sem efeito todos os itens da NOB 96 relacionados ao mesmo. E criou um novo incentivo ao incremento das ações básicas de Vigilância Sanitária - conceituadas como "ações básicas de fiscalização e controle sanitário em produtos, serviços e ambientes sujeitos à Vigilância Sanitária" - e às atividades de educação em Vigilância Sanitária (Artigo 5, \$4); esse novo incentivo se incorporou à parte variável do Piso Assistencial Básico (PAB). ${ }^{10}$

A Portaria ne 2.091, de 26 de fevereiro de 1998, retificou o caput do Artigo 5, introduzindo a participação da CIT na definição dos critérios técnicos para o cálculo da parte variável do PAB.

A Portaria ne 2.283, de 10 de março de 1998, estabeleceu o valor, per capitalano, deste novo incentivo, em $\mathrm{R} \$ 0,25$ centavos para cada município brasileiro, para o ano de 1998.

E por fim, a Portaria n².565, de 4 de maio de 1998, estabeleceu que somente os municípios habilitados de acordo com a NOB 96 estão qualificados para receber o incentivo.

\section{Considerações finais}

A configuração da gestão descentralizada da Vigilância Sanitária vem sendo objeto de modificações, que podem implicar em mudanças substantivas da tendência inicial da proposta publicada na NOB 96.

\footnotetext{
10 O Piso Assistencial Básico (PAB), estabelecido pela NOB 96, consiste em um montante de recursos financeiros destinado exclusivamente ao custeio de procedimentos de atenção básica. A Portaria n² 1882/GM regulamenta o $\mathrm{PAB}$ e sua composição em duas partes: uma fixa, destinada à assistência básica e uma variável, relativa a incentivos para o desenvolvimento de açōes nas áreas de Vigilância Sanitária, Vigilância Epidemiológica e Ambiental, Assistência Farmacêutica Básica, Programas de Saú. de da Família e de Agentes Comunitários de Saúde, de Combate às Carências Nutricionais, e outros que venham a ser agregados.
} 
O processo de normatização complementar, em curso, procura melhor definir os campos de intervenção federal, estadual e municipal do sistema de Vigilância, para então operacionalizar as inovações previstas e necessárias, em particular, no que diz respeito ao financiamento.

Quanto a este aspecto, cabe uma observação: pela primeira vez na história da intervenção pública na área de Vigilância Sanitária introduziu-se o mecanismo de remuneração por serviços produzidos, através do PDAVS, e da remuneração de ações de média e alta complexidade. Ainda que estes instrumentos não estejam normatizados, cabe questionar a pertinência desse tipo de lógica para o financiamento de ações de impacto coletivo. Quais procedimentos deveriam compor uma tabela específica? Como atribuir valor a cada procedimento? Seria interessante criar a vinculação pagamento/produção para a Vigilância, quando são conhecidas as distorções que este mecanismo trouxe para a assistência médica ambulatorial e hospitalar? Por que "pagar" às SES e SMS pela execução de ações de alta e média complexidade, de competência estadual e municipal, através desse mecanismo? Não estaria a Vigilância Sanitária sacrificando a elaboração de um projeto inovador apenas para garantir uma fatia dos escassos recursos ministeriais, sugados, em sua quase totalidade, pela assistência médica, ambulatorial e hospitalar? Seria esta uma alternativa eficaz para garantir recursos para ações e serviços de qualidade?

O acompanhamento da política de saúde e a análise dos gastos do Ministério da Saúde, nos últimos anos, trazem preocupações quanto ao financiamento desta área, sempre subordinada às pressões financeiras colocadas pela necessidade de pagamento dos serviços de rede ambulatorial e hospitalar do SUS, nos três níveis de governo.

No entanto, a NOB 96 trata de operacionalizar novos mecanismos de repasse direto e automático de recursos fundo a fundo, como, por exemplo, o PAB e as condições de gestão plena de sistema municipal e plena de sistema estadual. O objetivo desse processo é reduzir o volume de recursos transferidos como pagamento de serviços produzidos e efetivar a descentralização da gestão da assistência médica ambulatorial e hospitalar para estados e municípios. Assim, não seria oportuno buscar alternativas mais criativas para financiar a Vigilância Sanitária?

Os canais de participação estão instituídos. O Ministério da Saúde, o CONASS e o CONASEMS têm posto à disposição da sociedade informações relevantes que permitem acompanhar os resultados do processo de formulação política. Cabe, a todos os interessados em contribuir e intervir no direcionamento da área, elaborar e encaminhar, seja através dos Conselhos de Saúde, das Comissões Intergestores, do CONASS, do CONASEMS, seja através de seu próprio local de trabalho, proposições consistentes e capazes de disputar prioridade na agenda de trabalho dos diferentes fóruns.

normatização complementar

questionamentos sobre a NOB 


\section{Referências bibliográficas}

INSTRUÇĀO NORMATIVA n² 01/93, de 23/09/93, publicada no Diário Oficial da Uniāo em $7 / 10 / 93$.

INSTRUÇĀO NORMATIVA n² 01/98, de 02/01/98, publicada no Diário Oficial da Uniāo em 06/01/98.

LUCCHESE, P. T. R., 1996. Descentralização do Financiamento e Gestão da Assistência à Saúde no Brasil: a Implementação do Sistema Único de Saúde. Retrospectiva 1990/ 1995, In: Planejamento e Politicas Públicas. Brasília: IPEA, ne 14, dezembro. 


\section{Organização jurídica da administração pública em saúde}

Sueli Gandolfi Dallari

\section{Estado constitucional, Estado de Direito e Estado Democrático de Direito}

A Constituição contemporânea é o documento onde se registram as conquistas do povo, em especial no que respeita aos seus direitos e garantias, à organização do governo e aos mecanismos de controle do exercício do poder. Tradicionalmente, a Constituição vem sendo o registro histórico do término de períodos revolucionários; isso explica a necessidade da forma escrita para o documento. Pode explicar, também, a necessidade de Constituições mais longas - com maior número de artigos, pois as funções do governo devem ficar claramente estabelecidas, para todos poderem controlar a maneira de se exercer o poder e, igualmente, compreender os limites dos direitos declarados e a extensão da garantia dos mesmos. ${ }^{1}$

Os burgueses idealizaram uma Constituição que se restringisse a estabelecer normas sobre o controle do poder dos governantes. As funções públicas seriam clara e taxativamente definidas. E todos os limites à atuação do Estado, visando proteger a liberdade e a propriedade individuais, seriam explicitamente apresentados. Isso era matéria constitucional. Contudo, a exigência de rigorosa observância das formalidades envolvidas - necessária à preservação da autonomia do indivíduo - transformou-se no próprio objeto constitucional. Por essa razão, passaram a figurar no corpo da Constituição normas que não têm natureza consti-
Constituição

\footnotetext{
${ }^{1}$ Para melhor compreensão do tema, inclusive da evolução histórica do conceito, veja-se DALLARI, D.A., 1985. Constituição e constituinte. São Paulo: Saraiva, 3a Edição.
} 
justiça $\mathrm{x}$ legalidade tucional, embora lhe preservem o rótulo; da mesma forma, passaram a existir leis que não são verdadeiras Leis. ${ }^{2}$

O Estado de Direito colocou sob controle da legalidade alguns atos da Administração - aqueles derivados da atuação concreta da lei, isto é. de aplicação, ao caso concreto, de normas gerais e abstratas. E manteve a exclusão dessa apreciação para todos os atos que o legislador não regulou. Esta esfera de atuação arbitrária do Estado foi restringida, sob influência do positivismo jurídico, passando a Administração a ser integralmente limitada pela lei. Nesse período histórico, que coincidiu com a mitificação da chamada teoria da separação dos poderes, a realidade revelou a injustiça como conseqüência de tal submissão. De fato, a existência de leis de sentido apenas formal desvinculou o exame da legalidade de uma preocupação com o Direito. A assunção do Estado Demo. crático de Direito, entretanto, ao vincular a justiça à legalidade, permite concluir estar a discricionariedade administrativa limitada tanto pela lei como pela idéia de justiça. Assim, o administrador se vê obrigado a interpretar o conceito adotado pela norma jurídica e a valorizar os princípios constitucionais, determinando as diretrizes aplicáveis ao caso e buscando, na realidade, os elementos que lhe permitam precisar os termos que o exprimem. Somente então lhe poderá ser reconhecida a prerrogativa de decidir entre duas ou mais soluções, consideradas juridicamente perfeitas, a que melhor atende às necessidades coletivas. ${ }^{3}$

Ora, o Brasil definiu-se, em 1988, como um Estado Democrático de Direito (C.F. art.1@), ou seja, adotou o princípio básico do chamado Estado de Direito de vincular a Administração Pública às estritas previsões legais. Não existe plena autonomia da vontade quando está em pauta a prática de um ato administrativo. Assim, enquanto para o indivíduo é lícito fazer tudo aquilo que a lei não proíbe, na administração da coisa pública "só se pode querer o que sirva para cumprir uma finalidade antecipadamente estabelecida em lei." ${ }^{4} \mathrm{E}$ as leis, único instrumento hábil para criar, modificar ou extinguir direitos, em um Estado Democrático de Direito, só podem ser feitas, com autenticidade, pelo povo. Essa expressão supera, portanto, os conceitos de Estado Democrático e de Estado de Direito, incorporando-lhes um componente de

\footnotetext{
2 Isto é possível porque, embora seus conteúdos não correspondam a matérias a serem tratadas por uma lei ou pela Constituição - a Lei Maior -, obedeceram a todos os procedimentos previstos para a feitura, quer seja de uma lei, quer seja de uma regra constitucional.

3 É esclarecedora a análise da doutrina, sobre esse tema, realizada pela professora Maria Sylvia Zanella DI PIETRO, 1990, em sua tese Da discricionariedade administrativa. São Paulo: FADUSP.

4 Cf. BANDEIRA DE MELLO,C.A., 1981. Ato administrativo e direito dos administrados. Sâo Paulo: Revista dos Tribunais, p. 13.
} 
transformação, verdadeiramente revolucionário: o direito há que ser democrático. ${ }^{5}$

A afirmação da exigência de legalidade formal no Estado de Direito fez com que, especialmente nos Estados de tradição legal codificada - como o Brasil, por exemplo - a Administração se vinculasse absolutamente à lei. Assim, a capacidade de regular comportamentos, detida pelo Poder Executivo, nesses Estados, é quase nula, uma vez que a lei tende a descrever - com o maior número de detalhes possível - os comportamentos autorizados, e os proibidos. A experiência dos Estados com tradição de direito costumeiro - como os anglo-saxões - é bastante diferente. Assim, tomando-se a Constituição dos Estados Unidos da América como exemplo, observa-se que a legalidade exigida como conseqüência da separação de poderes admite grande capacidade reguladora da Administração Pública. A lei define os princípios e os grandes objetivos a serem atingidos pelo Estado, e o poder executivo - por meio de normas administrativas - disciplina os comportamentos para a consecução daquelas metas.

No Brasil, a exigência de legalidade estrita dos atos da Administração é matéria constitucional. Com efeito, quando enumera as competências do Chefe do Poder Executivo, a Constituição estabelece que a ele cabe "expedir decretos e regulamentos para sua (da lei) fiel execução" e que, mesmo para "dispor sobre a organização e o funcionamento da administração" será necessário fazê-lo "na forma da lei" (C.F. art.84, IV e VI). À Administração, portanto, resta um pequeno poder para regulamentar qualquer comportamento, poder cujos limites são dados pela lei em sentido estrito, ou seja, por aquela norma originada do processo legislativo adotado nos Parlamentos.

Entre os atos administrativos está, primeiramente, o decreto, reservado ao Chefe do Poder Executivo; esse ato só pode ser expedido para fiel execução da lei, sendo assim, um decreto regulamentar. Convencionou-se que os demais atos administrativos normativos, emanados de autoridade que não o Chefe do Executivo, revestem a forma de resolução ou de portaria. Chama-se circular ao documento que transmite ordens internas, uniformes, da chefia aos subordinados; despacho é a forma da decisão da autoridade administrativa sobre processo submetido à sua apreciação; ao ato de aprovação de parecer proferido por órgão técnico sobre assunto de interesse geral, chama-se despacho normativo;

\section{Administração e lei}

decreto, resolução, portaria, circular, despacho, alvará

5 O professor José Afonso DA SILVA, em seu Curso de Direito Constitucional Positivo. São Paulo: Revista dos Tribunais, situa a origem doutrinária do conceito em Portugal, na Espanha e na Alemanha. 
este ato obriga a toda a Administração; alvará é a forma do instrumento de licença ou autorização.

É imperioso lembrar, contudo, ser a Constituição um documento político que transforma em lei os objetivos da sociedade, e inclusive a organiza para os alcançar. Cumpre, portanto, reconhecer a primordial importância dos princípios que, mesmo se não-explicitados, conformam o documento, pois refletem valores que caracterizam uma dada sociedade, derivados de seu contexto político e social. ${ }^{6} \mathrm{E}$ entre os princípios constitucionais, se impõe, com freqüência a solução do conflito que os envolve, certamente presente. Assim, a defesa do meio ambiente e a manutenção da livre iniciativa - princípios abrigados na vigente Constituição brasileira - podem opor-se frontalmente. E porque se trata de princípios, a solução do conflito pode considerar a importância atribuída a cada um deles. ${ }^{7}$ Não há, portanto, qualquer dúvida sobre a prioridade da análise principiológica quando se pretende a implementação constitucional. 8

Hoje se exige do constituinte o mínimo de respeito aos seus representados, que escreva somente o que se pretende seja efetivo direito do povo e do Estado. ${ }^{9} \mathrm{~A}$ teoria da Constituição não se compraz em acolher, no seio constitucional, as chamadas normas programáticas, pois uma Constituição moderna deve conter apenas normas aplicáveis; as regras que refletem objetivos quiméricos, de alcance antevisto apenas como sonho, não são normas constitucionais.

A assunção, no texto constitucional, dos resultados que se pretende alcançar com a implementação de políticas permite distinguir normas que têm o caráter de diretrizes para a atuação e a interpretação do Direito. É importante as distinguir, claramente, das normas programáticas, para não se as caracterizar como simples expedientes, travestidos de normas, das quais não se espera algum efeito jurídico. As diretrizes constitucionais estabelecem obrigação de resultado e vinculam a legalidade da norma à submissão aos fins nelas declarados. E, freqüentemen-

\footnotetext{
6 As bases políticas da lei e, especialmente, o papel dos princípios são discutidos na obra, clássica, de Ronald DWORKIN, 1985. A matter of principle. Cambridge: Harvard University Press.

${ }^{7}$ Eros Roberto GRAU, 1990. Contribuição para a interpretação e a crítica da ordem econômica na Constituição de 1988. São Paulo (tese), especialmente no capítulo dedicado ao Estado a à economia, p. 39 a 62 . 8 No Brasil, nos tempos hodiernos, o professor Celso Antônio BANDEIRA DE MELLO divulgou esta tese, já defendida, no continente americano, por Agustin GORDILLO. (in Elementos de direito administrativo. São Paulo: Revista dos Tribunais,1980).

9 É o entender unânime dos mais importantes constitucionalistas contemporâneos: CANOTILHO, J.J.G., 1982. Constituiçâo dirigente e vinculaçâo do legislador. Coimbra: Coimbra; GRAU, E.R., 1988. Direito, conceito e normas jurídicas. São Paulo: Revista dos Tribunais; FERRAJOLI,L., 1989. Diritto e ragione. Roma: Laterza.
} 
te, empregam conceitos abertos, em especial porque essas normas devem ser aplicadas a inúmeras situações, de difícil determinação prévia. Os termos que as expressam, conforme acolhidos na diretriz, exigem a consideração da realidade onde a norma há de se efetivar. ${ }^{10}$

Em particular quanto à formulação e à implementação de políticas públicas, quando mais se exige do administrador o preenchimento de conceitos jurídicos abertos, é necessária clareza na distinção entre princípios e diretrizes, e regras jurídicas. Trata-se de viabilizar a aplicação das normas que o povo fixou para a gestão da vida social, normas que têm um único e determinado sentido. E tais regras tanto podem estar contidas em princípios e diretrizes constitucionais, como na norma jurídica infraconstitucional. Já se observou que, dada a inexorabilidade da interpretação constitucional realizar-se por inteiro, o primeiro parâmetro para a compreensão da mesma será a valoração dos princípios que informam a Constituição. Assim, cabe ao aplicador, ou ao intérprete, da norma escolher, entre princípios expressos por termos imprecisos, aquele mais importante para a manutenção do sistema, cabe-lhe decidir da legalidade da regra de direito. ${ }^{11}$

A própria norma jurídica contém, em muitos casos, conceitos expressos por termos ambíguos ou imprecisos. Em particular quanto à atividade administrativa de implementação de políticas públicas, dada a variabilidade, no tempo e no espaço, das necessidades coletivas, os conceitos abertos seduzem o legislador. Pois esses conceitos se amoldam à exigência de reação administrativa conveniente e oportuna àquelas necessidades. Torna-se, portanto, imprescindível reconhecer a necessidade do exercício da discricionariedade na função administrativa, para se poder julgar da legalidade dos atos decorrentes da aplicação de conceitos vagos.

\section{Controle social na democracia direta e representativa: mecanismos constitucionais de participação social em saúde}

A Constituição federal reconheceu que o direito à saúde deve ser garantido, e criou mecanismos privilegiados para a proteção do mesmo.

\footnotetext{
10 Eros Roberto GRAU, partindo do estudo da doutrina referente à natureza das normas de planejamento, analisa exaustivamente a literatura sobre o tema, optando por nomear essa espécie legal normas-objetivo. Seu trabalho encontra-se publicado em Direito, conceitos e normas jurídicas. São Paulo: Revista dos Tribunais, 1988. ${ }^{11}$ Essa conclusão, que pode assustar os tradicionais defensores do positivismo jurídico, é exemplarmente justificada na análise da decisão da Corte de Cassação belga, realizada por Chaïm PERELMAN, La logica juridica y nueva retorica. Madrid: Civitas, 1979.
}

discricionariedade na função administrativa 
direito à saúde

e Poder Judiciário
O primeiro foi a afirmação - a rigor desnecessária - de terem aplicação imediata todas as normas que definem direitos e garantias individuais (C.F.art.5e,\$ 1^). Assim, qualquer lei cujo conteúdo ajude a definir o direito à saúde, em qualquer esfera de governo, permite o recurso ao Poder Judiciário, em não sendo imediatamente aplicada.

A decisão do povo brasileiro de assumir seu próprio governo se revela no artigo que inaugura a Constituição: é ao povo que pertence todo o poder. E para exercitar o poder o povo pode eleger representantes ou agir em nome próprio (C.F.art.12, \$un.). Assim, tanto a organização do governo como o controle do poder econômico e a garantia dos direitos das pessoas, consideradas individualmente ou na coletividade, - matérias que devem fazer parte de qualquer Constituição, no final do século vinte - permitem a atuação imediata do povo, fonte de todo o poder. Para assegurar a participação popular na gestão do Estado, previu-se que a capacidade legislativa pertence aos representantes eleitos e a quem os elegeu, previu-se que o povo pode propor projetos de lei (C.F. art. 61,\$2 ), participar de audiências para debatê-los (C.F.art. $\left.58, \$ 2 \_, \mathrm{II}\right)$, referendar uma lei ou se manifestar - em plebiscito - sobre assuntos considerados relevantes pelo Congresso Nacional (C.F.art.49, $\mathrm{XV}$ ). Do mesmo modo, o povo, organizado em confederação sindical, ou entidade de classe, ou em partido político, pode pedir a retirada, do mundo jurídico, de uma lei contrária à Constituição (C.F.art. 103,VIII e IX).

É necessário lembrar, contudo, que o poder legislativo é o representante tradicional do povo nas democracias liberais burguesas. Todos os direitos podem, e devem, portanto, ser garantidos através da participação dos parlamentares. Assim, tanto as Assembléias Legislativas estaduais - e seus órgãos assessores, como o Tribunal de Contas, - quanto as Câmaras de Vereadores, desempenham importante papel na garantia do direito à saúde.

A organização federativa do Estado brasileiro favorece o controle popular do governo. Ao aproximar, territorialmente, governantes e governados, essa forma de Estado vem sendo julgada a que melhor se adapta às exigências da democracia no Brasil. Contudo, não se podem esquecer as origens alienígenas das instituições brasileiras. Sem dúvida, essas origens respondem, em grande parte, pelo tratamento simétrico dispensado aos Municípios e Estados-membros da Federação, supondo a homogeneidade deles, fato evidente ao observador da realidade. Assim, a distribuição constitucional de competências e, portanto, de responsabilidades, ao tratar igualmente entes políticos cuja desigualdade sociocultural e econômica é óbvia, dificulta o emprego de instrumentos, em princípio, eficazes. 
Portanto, é necessário reafirmar-se a importância dos legislativos regionais e locais e a sua possibilidade de adequar os mecanismos de controle social à realidade, para que sirvam efetivamente como instrumentos de garantia de direitos. É bom lembrar, também, que os Tribunais de Contas, apesar de vinculados ao Poder Legislativo - e, consequentemente, aos representantes do povo - mantêm com esse uma ligação direta, conforme disposição da Constituição Federal. O cidadão, os partidos políticos, as associações e os sindicatos têm a capacidade, legítima, de fiscalizar a contabilidade, os financiamentos, o orçamento das entidades administrativas, e de denunciar irregularidades aos Tribunais de Contas (C.F.art.74, $\$ 2$ ).

Os constituintes criaram, também, mecanismos de participação direta na Administração Publica, instituindo órgãos populares com funções de direção administrativa, inclusive, no sistema de saúde (C.F.art. 198,III) ou de subordinação de todo o planejamento da atuação estatal, no Município, à cooperação das associações (C.F.art.29,X). Especialmente em relação à saúde, as Conferências de Saúde são "instâncias colegiadas...(com).... representação dos vários segmentos sociais, para avaliar e propor as diretrizes para a formulação da política de saúde nos níveis correspondentes" (Lei n² 8.142 art.1^). As Conferências de Saúde representaram um dos mecanismos pensados para cumprir o mandamento constitucional que exige ter a organização do sistema de saúde a participação da comunidade. Ordinariamente, essas Conferências devem ser convocadas pelo chefe do Poder Executivo, em cada esfera de governo, e se reunirem a cada quatro anos. Apenas em caráter extraordinário poderão ser convocadas tanto pelo Chefe da Administração quanto pelo Conselho de Saúde daquela esfera de poder. De modo ideal, as Conferências de Saúde representam o momento adequado para articular, internamente, as diversas competências sanitárias atribuídas a determinado nível de governo e, externamente, para as articular às demais políticas que interessam à saúde, na mesma esfera, ou nas demais, exclusivamente sanitárias ou não.

Os Conselhos de Saúde são o outro mecanismo previsto para assegurar o cumprimento do mesmo mandamento constitucional (participação da comunidade na organização do sistema). Esses Conselhos têm caráter permanente e deliberativo, são órgãos colegiados, integrados por representantes do governo, dos prestadores de serviço, dos profissionais de saúde e dos usuários e devem atuar na formulação de estratégias e no controle da execução da política de saúde - inclusive nos aspectos econômicos e financeiros - da esfera política correspondente; as decisões dos Conselhos de Saúde são homologadas pelo chefe do Poder Executivo nessa esfera. Note-se que a Lei Orgânica da Saúde (ver legislativos regionais e locais, Tribunais de Contas e controle social

Conselho de Saúde, Conferências de Saúde e participação da comunidade 


\section{Conselho Municipal de Saúde e Vigilância Sanitária}

adiante) estabeleceu, também, a obrigatoriedade de destinar metade das vagas de cada Conselho de Saúde a representantes dos usuários. Estabeleceu, assim, que a participação da comunidade deve privilegiar a representação dos usuários, restando ao governo, aos prestadores de serviço e aos profissionais, o preenchimento das demais vagas de representação. A LOS previu, igualmente, que a "Organização e as normas de funcionamento...(dos Conselhos de Saúde devem estar)...definidas em regimento próprio aprovado pelo respectivo Conselho" (Lei n 8.142 art.1, \$5익.

Entre as obrigações gerais constantes da Constituição Federal e da LOS, o Conselho Municipal de Saúde tem as seguintes incumbências, relacionadas diretamente à Vigilância Sanitária, incumbências que não podem, em nenhuma hipótese, ser ignoradas:

1) formular estratégias para a política de saúde - inclusive nos aspectos econômicos e financeiros - do Município;

2) controlar a execução da política municipal de saúde - inclusive nos aspectos econômicos e financeiros;

3) utilizar a epidemiologia para o estabelecimento de prioridades, a alocação de recursos e a orientação programática;

4) participar, em articulação com o Estado, do planejamento e da programação da rede regionalizada e hierarquizada de ações e serviços de saúde;

5) criar comissão permanente de integração entre os serviços de saúde e as instituições de ensino profissional e superior, com o fim de propor prioridades, métodos e estratégias para a formação e a educação continuada dos recursos humanos do sistema municipal de saúde e para a pesquisa e a cooperação técnica entre essas instituições;

6) definir as instâncias e os mecanismos de controle, avaliação e fiscalização das ações de saúde;

7) apreciar a proposta orçamentária do sistema municipal de saúde conforme ao plano de saúde;

8) fiscalizar a conta especial a que se deve recolher os recursos financeiros do SUS;

9) participar na formulação da política de saneamento básico;

10) participar da elaboração e da atualização periódica do plano municipal de saúde;

11) promover a articulação da política e dos planos de saúde.

Além dessas atribuições, o Conselho Municipal de Saúde é responsável, sem dúvida, pela execução das tarefas que lhe forem determinadas na Lei Orgânica de seu Município. Será também necessário examinar, com cuidado, a Constituição estadual para verificar se contém obrigações que - segundo a Constituição Federal - podem ser de responsabilidade dos Conselhos Municipais de Saúde do Estado. 
E, para não restar qualquer dúvida sobre a obrigação constitucional do encarregado da Administração Pública de obedecer e de fazer cumprir os direitos afirmados, a Constituição define como crime de responsabilidade do Presidente da República os atos que atentem contra o "exercício dos direitos políticos, individuais e sociais" (C.F.art.85, III).

Considerando-se a tradicional teoria da separação de poderes, fundamento do Estado contemporâneo, nascida das revoluções burguesas, pode-se afirmar que o único Poder a permanecer impermeável à participação direta das pessoas foi o Judiciário, com a única exceção do Tribunal do Júri. Houve, entretanto, enorme alargamento nas possibilidades de acesso a esse poder. Assim, para proteger um direito desrespeitado por autoridade pública, ou por quem esteja exercendo função pública, previu-se o mandado de segurança, a ser impetrado pelo indivíduo ofendido ou por partido político, organização sindical, entidade de classe ou associação, na defesa de seus membros ou associados (C.F.art.5, LXIX e LXX); e, para garantir o acesso à informação e sua veracidade permitiu-se, apenas ao interessado, o uso do habeas data (C.F.art.5, LXXII). Todo cidadão é legitimado para propor ação que vise anular ato lesivo ao patrimônio público amplamente considerado (C.F. art.5e, LXXIII). O mandado de injunção é outro instrumento a revelar as inúmeras possibilidades de participação do povo em diversas funções do Poder político. Por meio desse instrumento, qualquer pessoa pode pedir que o juiz faça valer o direito criado pelo constituinte, e não regulamentado pelo legislador, ou nem aplicado pelo administrador (C.F.art.5^, LXXI). Considerando que as associações também estão legitimadas a utilizar tal instrumento, é fácil imaginar-lhe a utilidade quando o povo se convencer de serem todos os direitos declarados, efetivamente, direitos constitucionais.

Por outro lado, pela primeira vez na história constitucional brasileira, se definiram, com clareza, as funções do órgão especialmente voltado para "a defesa da ordem jurídica, do regime democrático e dos interesses sociais e individuais indisponíveis." (C.F.art.127 a 130). Trata-se do Ministério Público que, junto a qualquer Juízo, é o advogado do povo na defesa dos direitos assegurados na Constituição. Esse órgão é, igualmente, um investigador privilegiado, pois lhe é garantido o acesso às informações necessárias ao exercício de suas funçōes, mesmo quando essas informações estejam sob a guarda da Administração. E foi, também, instituída a Defensoria Pública para a "orientação jurídica e a defesa, em todos os graus dos necessitados" (C.F.art.134); entretanto, o Poder Executivo federal não efetuou, como era seu dever constitucional, a implantação de Defensoria Pública. mandado de segurança

habeas data

mandado de injunção

Ministério Público

Defensoria Pública 
Em especial no que interessa à saúde, em virtude da expressão constitucional "relevância pública", o Ministério Publico está diretamente envolvido. Com efeito, em 4 de outubro de 1991 algumas das mais expressivas figuras do meio jurídico nacional assinaram um documento em que externaram seu entendimento da expressão "relevância pública", adotada na Constituição da República Federativa do Brasil, em 1988. Eminentes professores de Direito, dirigentes das Procuradorias da República e da Justiça do Estado de São Paulo e da Associação Brasileira dos Magistrados, juizes federais, desembargadores, procuradores da República e promotores públicos concordaram em que "A correta interpretação do artigo 196 do texto constitucional implica o entendimento de ações e serviços de saúde como o conjunto de medidas dirigidas ao enfrentamento das doenças e suas seqüelas, através da atenção médica preventiva e curativa, bem como de seus determinantes e condicionantes de ordem econômica e social... E que tem o Ministério Público a função institucional de zelar pelos serviços de relevância pública, dentre os quais as ações e serviços de saúde, adotando as medidas necessárias para sua efetiva Prestação, inclusive em face de omissão do Poder Público." 12

De todo o exposto se evidencia a conclusão de ser o povo organizado a garantia, por excelência, dos seus direitos e, em especial, do direito à saúde. A rigor, em todàs as hipóteses tratadas até aqui, se percebe, claramente, a importância do papel que as organizações populares podem representar para a garantia do direito à saúde. Existe, como se verificou, espaço para a atuação direta dessas associações junto ao Poder Legislativo e junto à Administração Pública, e mesmo junto ao Judiciário. É indispensável lembrar, entretanto, que para agir de modo legítimo, reivindicarem direitos, na estrutura jurídica, as associações devem estar formalmente constituídas e expressamente autorizadas por seus associados.

Em suma, o Brasil pode ser tão democrático quanto sua Constituição. Não há necessidade de mudança constitucional para o povo poder controlar o governo. Isso é verdade, sobretudo, no que se refere ao sistema de saúde, onde a participação popular é indispensável. Entretanto, as mudanças sociais não derivam apenas da criação constitucional dos mecanismos que as possibilitem, mas, principalmente, do uso de tais instrumentos. Uma campanha que torne conhecidas a existência de direitos - verdadeiros direitos, porque escritos no texto constitucional e

\footnotetext{
12 DALlaRI, Sueli Gandolfi et all, 1992. O Conceito Constitucional de Relevância Pública. Organização Panamericana da Saúde. Série Direito e Saúde, 1.
} 
por ele garantidos - e as possibilidades de controle popular do governo, e alerte para as vantagens do envolvimento do Ministério Público e das associações comunitárias na luta pelo respeito aos direitos assegurados na Constituição, pode conduzir à democracia.

\section{Descentralização política: o federalismo e a distribuição constitucional das competências em matéria sanitária entre as três esferas de governo}

A Constituição promulgada em 1988 afirma, explicitamente, o direito de todos à saúde. Assim, a saúde é reconhecida como direito social (C.F.art.6e) de todos os brasileiros e estrangeiros residentes no País (C.F.art.196 c/c art.5). E, para a garantia da saúde, imposta, literalmente, como "dever do Estado" (C.F.art.196), esta Constituição define obrigações de todos os níveis de governo da federação.

A distribuição constitucional de competências é uma exigência do federalismo. É fácil imaginar que, no momento em que se considerava a Constituição como o documento fundamental do Estado contemporâneo, a conter, necessariamente, a organização do poder estatal, a distribuição territorial desse poder constaria obrigatoriamente de tal documento. E a história da criação do primeiro Estado federal (os Estados Unidos da América do Norte) ilustra com precisão ímpar a exigência de o texto constitucional conter expressas as competências de cada esfera de poder político nesse Estado. Decorrente de uma subversão da Convenção de Filadélfia, adrede preparada pelos representantes do Estado de Nova Iorque, os embaixadores que votaram a extinção de seus Estados quiseram deixar suficientemente claro quais poderes outorgavam ao novo Estado que acabavam de criar.

Muitos doutrinadores consideram constituir a participação, juntamente com a autonomia, o principio fundamental do federalismo. Assim, tanto é necessária a conservação da autonomia das unidades federadas, no que respeita às competências atribuídas às mesmas, como é indispensável a participação de todas as esferas de poder político na formação da vontade estatal, expressa nas leis nacionais.

A República brasileira nasceu federalista, copiando em quase tudo, literalmente, o modelo estadunidense. Assim, o Decreto n 1, de 15 de novembro de 1889 transformou as antigas províncias do Império em Estados independentes e, no mesmo artigo, lhes supôs a adesão ao pacto federal, que constituía, então, os Estados Unidos do Brasil (arts.2@e 32). E, ainda sob o fascínio da centenária experiência dos confrades da América do Norte, a constituição promulgada em 1891 esclarecia que

federalismo 
autonomia municipal

competência

concorrente e comum os Estados (membros) mantinham todos os poderes que não houvessem sido, expressamente, entregues a outras esferas de governo, ou que não lhes fossem, de outro modo, defesos (art.65,\$2). Essa é a técnica que a doutrina tradicional denomina clássica: enumeram-se as competências da União e atribui-se o poder remanescente aos Estados.

A experiência histórica, entretanto, prevalece sobre qualquer modelo teórico, como se constata no caso mesmo da primeira Constituição republicana brasileira. Rigorosamente, não se pode afirmar que essa Constituição adotou o federalismo dual, uma vez que declara serem três as esferas de poder político, e dispôs que os Municípios teriam sua autonomia assegurada em tudo que respeitasse seu peculiar interesse (art.68). Importa, portanto, delimitar claramente as atribuições de cada autonomia para que ainda se possa falar da teoria clássica de repartição de competências do Estado Federal.

A autonomia municipal, afirmada na primeira Constituição republicana, decorreu de exigências históricas. Assim, "se a autonomia municipal não é da essência do federalismo, em geral, tornou-se, todavia, um elemento essencial ao federalismo brasileiro." 13 Esta constatação obriga o estudioso da repartição constitucional de competências, no Brasil, a identificar, também, as atribuições próprias desse nível de governo.

A crise econômico-social do fim dos anos trinta, do século vinte, conhecida como a Grande Depressão, obrigou os três ramos do poder político da união estadunidense, forçados pela realidade social, a adotar o programa chamado New Deal. A partir dele começa a construção teórica do "federalismo cooperativo", e passam a existir atribuições não mais exclusivas de cada esfera de governo. Supondo ser possível a generalização doutrinária, os autores contemporâneos concordam, essencialmente, com a exigência - no federalismo de cooperação - de campos específicos para a atuação de cada nível de poder político. ${ }^{14}$ Isto não significa a impossibilidade de ação conjunta, bem ao contrário. A cooperação definiu o que se convencionou denominar competência concorrente e comum.

Inicia-se a execução comum das tarefas políticas por um critério que, além de supor o acordo, ou a vontade recíproca do trabalho conjunto, estabelece a prioridade para determinar a disciplina no exercício

\footnotetext{
13 Cf. REALE, M. Nos quadrantes do direito positivo. São Paulo: Michalany, s.d. p.54.

$14 \mathrm{Em}$ sua tese de doutoramento apresentada à Faculdade de Direito da Universidade de São Paulo, em 1991, a professora Fernanda Dias Menezes de ALMEIDA discute as questōes terminológicas relacionadas às competências próprias.
} 
daquela atividade. Esse critério é a chamada competência concorrente. Sua caracterização depende, portanto, da existência de uma única tarefa, a ser desempenhada por mais de uma unidade federativa, segundo um critério de primazia anteriormente definido. Quando não existe primazia entre os responsáveis pela execução do encargo, mas, ao contrário, supõe-se a igualdade das diversas esferas federativas, a agir em conjunto, "sem que o exercício de uma venha a excluir a competência de outra"15, fala-se de competência comum.

A técnica legislativa adotada pela constituição brasileira de 1988 privilegiou a "competência comum" para atender aos reclamos populares de atuação estatal. E o fez não excluindo da obrigação de cooperação qualquer ente federativo. É fundamental notar que, assim procedendo, o constituinte afirmou a responsabilidade da União, dos Estados, do Distrito Federal e dos Municípios pela execução das tarefas sociais que julgou essenciais à adequada ordem soberana. Para evitar conflitos entre os responsáveis, ora por ação, ora por omissão, a constituição previu a edição de uma lei que a completasse, fixando "normas para a cooperação entre a União e os Estados, o Distrito Federal e os Municípios, tendo em vista o equilíbrio do desenvolvimento e do bemestar em âmbito nacional" (art.23,par.único).

É evidente que, em se tratando de competências comuns, as responsabilidades são, igualmente, comuns. Assim, apenas nos casos concretos em que um documento legal, obedecendo às determinações constitucionais, tenha distribuído as tarefas - e, portanto, a responsabilidade - a determinada esfera de governo, em atenção à necessidade de equilíbrio do desenvolvimento e do bem-estar nacional, será possível responsabilizar prioritariamente aquele nível governamental. Este ponto, entretanto, ainda não encontrou o consenso doutrinário.

A Constituição da República Federativa do Brasil, de 1988, disciplinou as atividades de governo a fim de se garantir o direito à saúde para todos. Considerando ser o "cuidar da saúde" tarefa de todos, incluiu-o entre as competências comuns à União, aos Estados, ao Distrito Federal e aos Municípios (art.23,II). E definiu a competência legislativa concorrente para a proteção e a defesa da saúde, atribuindo à União o estabelecimento das normas gerais, e aos Estados e aos Municípios a suplementação das mesmas (art.24,\$s1^e 2 e c/c art.30,II). E, preocupado em garantir que as atividades de atendimento à saúde da população e, portanto, de seu cuidado, partissem das necessidades 15 DA SILVA, José Afonso, 1998. Curso de Direito Constitucional Positivo. São Paulo: Revista dos Tribu-
nais. p. 415 . 
Lei $\mathrm{n} 98.080$, de 19 de setembro de 1990 , Lei no 8.142, de 28 de dezembro de 1990, Lei Orgânica da Saúde expressas na esfera municipal, e se lhes adequassem, o constituinte brasileiro afirmou a competência do Município para "prestar, com a cooperação técnica e financeira da União e do Estado, ...(esses)..serviços" (art.30, VII).

Assim, o exame da atribuição de competências, em matéria sanitária, revela que a Constituição federal vigente não isentou qualquer esfera de poder político da obrigação de proteger, defender e cuidar da saúde. Portanto, a saúde - "dever do Estado" (art.196) - é responsabilidade da União, dos Estados, do Distrito Federal e dos Municípios. ${ }^{16}$

\section{As competências municipais em matéria de saúde decorrentes da LOS}

Considerando, então, a afirmação do Estado Democrático de Direito, foram elaboradas as leis que "regulam, fiscalizam e controlam as ações e os serviços de saúde", conformes ao mandamento constitucional. São elas a Lei ne 8.080, de 19 de setembro de 1990 e a Lei 8.142 , de 28 de dezembro de 1990, conhecidas, em seu conjunto, como Lei Orgânica da Saúde. Assim, o Sistema Único de Saúde - SUS - é definido legalmente como "o conjunto de ações e serviços de saúde, prestados por órgãos e instituições públicas federais, estaduais e municipais, da administração direta e indireta e das fundações mantidas pelo Poder Público" (Lei n? 8.080 , art.4e). A Lei Orgânica da Saúde - LOS - é, portanto, o conjunto dessas duas leis, editadas para dar cumprimento ao mandamento constitucional de disciplinar a proteção e a defesa da saúde, tarefa de competência concorrente de todas as esferas públicas.

No Brasil, apenas a Constituição promulgada em 1988 esclareceu, de maneira expressa, o critério de hierarquia subjacente às competên. cias concorrentes, ao prever que "no âmbito da legislação concorrente, a competência da União limitar-se-á a estabelecer normas gerais" (art. 24, Ss.12 e 2 ㅇ), a serem suplementadas pelos Estados. E o próprio texto constitucional prevê, também, a competência dos Municípios para "suplementar a legislação federal e estadual no que couber" (art.30,II). O constituinte de 1988 não deixou, portanto, qualquer espaço para a criação doutrinária ou jurisprudencial na matéria: à União, nas tarefas definidas, constitucionalmente, como competência legislativa concor-

\footnotetext{
16 Para melhor compreensão da distribuição constitucional de competências em matéria sanitária ver DALLARI,S.G., 1991. O papel do Municipio no desenvolvimento de políticas de saúde. Revista de Saúde Pública, São Paulo, 25 (5).
} 
rente, cabe apenas a fixação das normas gerais. E essa limitação implica a primazia da vontade federal nos campos assim definidos, uma vez que quando Estados ou Municípios neles exercerem nesse campo "a competência legislativa plena... (- na inexistência de lei federal sobre normas gerais $-1 . .$. , para atender a suas peculiaridades, a superveniência de lei federal sobre normas gerais suspende (-lhes-)...a eficácia, no que lhe for contrário." (art.24,\$s.3e 4c/c art.30,II).

Existe, todavia, espaço para a interpretação dos magistrados e constitucionalistas, no que se refere à compreensão das normas gerais. Entretanto, uma análise da copiosa produção sobre o tema ${ }^{17}$, que já constava em Constituições anteriores, permite caracterizar-se-lhes os elementos essenciais. Assim, as normas gerais são declarações principiológicas editadas pela União que, sem violar a autonomia dos demais entes federativos, estabelecem as diretrizes nacionais que devem respeitar quando da elaboração de suas próprias leis. ${ }^{18}$

Isto significa que as Leis n 8.080 e 8.142 , ambas de 1990 - por circunstâncias políticas, contém uma parte daquilo que, no conjunto, se denomina Lei Orgânica da Saúde (LOS); são leis nacionais, com caráter de norma geral. Portanto, a LOS contém as diretrizes e os limites a serem respeitados pela União, pelos Estados e pelos Municípios ao elaborarem suas próprias normas para garantirem - em seus respectivos territórios - o direito à saúde para seus povos. Consequentemente, sempre que uma esfera de poder político atue, seja material, seja normativamente, está obrigada à disciplina imposta na LOS. Assim, todas "as ações e serviços de saúde, executados, isolada ou conjuntamente, em caráter permanente ou eventual, por pessoas naturais ou jurídicas de direito público ou privado" (Lei ne 8.080, art.12) são reguladas pela LOS.

De modo especial, a LOS colabora na definição do direito à saúde; estrutura o SUS, tornando claros seus objetivos e suas atribuições, as diretrizes que devem orientar suas organização, direção e gestão, a forma como estão distribuídas as tarefas entre as três esferas de poder e a forma de participação da comunidade na gestão do sistema em cada uma dessas esferas; disciplina a participação dos serviços privados na prestação de assistência à saúde; disciplina a formulação e execução da política de recursos humanos na área da saúde; organiza o financiamento do SUS - tratando, expressamente, dos recursos, da gestão financei-

\footnotetext{
17 Sempre citada, porque pioneira, a contribuição de ATALIBA,G., 1969. Normas gerais de Direito financeiro. São Paulo, Revista de Direito Público, v. 10,out/dez e a primeira síntese proposta por SILVA, J. A., 1981. Direito urbanístico brasileiro. São Paulo: Saraiva.

18 Cf. MOREIRA NETO, D. F., 1988. Competência concorrente limitada: o problema da conceituação das normas gerais. Brasilia, Revista de informação Legislativa, a. 25(100), out/dez.
} 
LOS e os Municipios ra, do processo de planejamento e do orçamento, inclusive das transferências intergovernamentais de recursos financeiros.

A LOS é, portanto, uma Lei-quadro, destinada a esclarecer o papel das esferas de governo na proteção e na defesa da saúde, e a lhes orientar as respectivas atuações para garantir o cuidado da saúde. Assim, buscando organizar as competências distribuídas pela Constituição federal relacionadas à saúde, a LOS deixa claras as tarefas que incumbem aos Municípios. São elas:

1) reformulação e execução de políticas econômicas e sociais que visem a redução de riscos de doenças e de outros agravos;

2) estabelecimento de condições que assegurem acesso universal e igualitário às ações e aos serviços de promoção, proteção e recuperação da saúde;

3) proporcionar assistência integral à saúde;

4) preservar a autonomia das pessoas na defesa de sua integridade física e psíquica;

5) garantir o direito à informação sobre sua saúde às pessoas assistidas;

6) divulgar informações quanto ao potencial dos serviços de saúde e a sua utilização pelo usuário;

7) utilizar a epidemiologia para o estabelecimento de prioridades, a alocação de recursos e a orientação programática;

8) prever e implementar mecanismos que garantam a participação da comunidade na gestão do sistema municipal de saúde;

9) reunir a Conferência Municipal de Saúde, a cada quatro anos, para avaliar a situação de saúde e propor as diretrizes para a formulação da política municipal de saúde;

10) mantèr um Conselho Municipal de Saúde, em caráter permanente, para formular estratégias e controlar a execução da política municipal de saúde;

11) ter uma secretaria municipal de saúde, ou órgão equivalente, para dirigir o sistema municipal de saúde;

12) integrar a execução das ações de saúde, de meio ambiente e de saneamento básico;

13) conjugar seus recursos financeiros, tecnológicos, materiais e humanos aos da União e do Estado, na prestação de serviços de assistência à saúde da população;

14) implementar a capacidade de resolução dos serviços de saúde;

15) evitar a duplicidade de meios para fins idênticos;

16) participar, em articulação com o Estado, do planejamento e da programação da rede regionalizada e hierarquizada de ações e serviços de saúde; 
17) organizar as ações e os serviços de saúde, de forma regionalizada e hierarquizada;

18) constituir consórcios com outros Municípios, sempre que conveniente e oportuno, para desenvolver, em conjunto, suas respectivas ações e serviços de saúde;

19) criar comissão permanente de integração entre os serviços de saúde e as instituições de ensino profissional e superior, com o fim de propor prioridades, métodos e estratégias para a formação e a educação continuada dos recursos humanos do sistema municipal de saúde, e para a pesquisa e a cooperação técnica entre essas instituições;

20) implantar um Plano de Carreira, Cargos e Salários para os recursos humanos vinculados ao sistema municipal de saúde;

21) definir as instâncias e os mecanismos de controle, avaliação e fiscalização das ações de saúde;

22) elaborar a proposta orçamentária do sistema municipal de saúde, conforme ao plano de saúde;

23) administrar os recursos orçamentários e financeiros destinados à saúde;

24) depositar, em conta especial - fiscalizada pelo Conselho Municipal de Saúde - os recursos financeiros do SUS;

25) elaborar relatórios de gestão que permitam o controle dos recursos repassados pela União e pelo Estado para a manutenção do sistema municipal de saúde;

26) aplicar pelo menos parcela igual à que recebe da União e do Estado na manutenção do sistema municipal de saúde;

27) assegurar a gratuidade das ações e serviços públicos de saúde;

28) acompanhar, avaliar e divulgar o nível de saúde da população e as condições ambientais;

29) organizar e coordenar o sistema municipal de informação em saúde;

30) elaborar, em complemento à atuação da União e do Estado, normas técnico-científicas de promoção, proteção e recuperação da saúde;

31) elaborar, em complemento à atuação da União e do Estado, normas técnicas e estabelecer padrões de qualidade e parâmetros de custos que caracterizam a assistência à saúde;

32) elaborar, em complemento à atuação da União e do Estado, normas técnicas e estabelecer padrões de qualidade para promoção da saúde do trabalhador;

33) participar da execução, do controle e da avaliação das ações referentes às condições, e aos ambientes, de trabalho;

34) participar na formulação da política e na execução das ações de saneamento básico;

35) executar serviços de vigilância epidemiológica; 
36) executar serviços de Vigilância Sanitária;

37) colaborar com a União e o Estado na execução das ações de Vigilância Sanitária de portos, aeroportos e fronteiras;

38) executar serviços de alimentação e nutrição;

39) executar serviços de saneamento básico;

40) executar serviços de saúde do trabalhador;

41) colaborar na proteção e na recuperação do meio ambiente;

42) colaborar na fiscalização das agressões ao meio ambiente municipal;

43) elaborar, e atualizar, periodicamente, o plano municipal de saúde;

44) organizar, controlar e avaliar as ações e os serviços de saúde;

45) gerir e executar os serviços públicos de saúde;

46) elaborar as normas para regulamentar a atividade de serviços privados de saúde;

47) controlar e fiscalizar os procedimentos dos serviços privados de saúde;

48) realizar operações externas, de natureza financeira, de interesse da saúde, sempre que convenientes e oportunas, e aprovadas pelo Senado Federal;

49) requisitar bens e serviços, tanto de pessoas naturais como jurídicas - assegurando-lhes justa indenização - para o atendimento de necessidades coletivas, urgentes e transitórias, decorrentes de situações de perigo iminente, de calamidade pública ou da irrupção de epidemias;

50) implementar o Sistema Nacional de Sangue, Componentes e Derivados;

51) gerir laboratórios públicos de saúde e hemocentros;

52) propor a celebração de convênios, acordos e protocolos internacionais relativos a saúde, saneamento e meio ambiente;

53) definir e controlar os padrões éticos para a pesquisa, as ações e os serviços de saúde, em articulação com os órgãos de fiscalização do exercício profissional e outras entidades representativas da sociedade civil;

54) promover a articulação da política e dos planos de saúde;

55) realizar pesquisas e estudos na área da saúde;

56) definir as instâncias e os mecanismos de controle e fiscalização inerentes ao poder de polícia sanitária;

57) fomentar, coordenar e executar programas e projetos estratégicos e de atendimento emergencial;

58) executar a política de insumos e de equipamentos para a saúde;

59) dar preferência às entidades filantrópicas, e sem fins lucrativos, quando for obrigado a recorrer a serviços da iniciativa privada para garantir a cobertura asssistencial do sistema municipal de saúde. 


\section{0 sistema nacional de proteção do consumidor}

Como já se verificou, a Constituição é um documento político e jurídico que assinala as conquistas sociais de um povo, e reflete a organização do mesmo. Assim, é fácil entender porque a defesa do consumidor foi incorporada ao texto constitucional brasileiro de 1988. Com efeito, o mesmo movimento que lutou contra os governos militares durante as décadas de 60,70 e 80 , deste século, promoveu o retorno à normalidade constitucional e, consequentemente, a afirmação e o respeito aos direitos, uma característica da democracia. Assim, tanto se buscava garantir o direito à saúde, quanto proteger os direitos dos consumidores, entre outros. A Constituição federal vigente assinala, portanto, que para garantir o direito à vida, à liberdade, à igualdade, à segurança e à propriedade, o Estado promoverá a defesa do consumidor (C.F.art.5\%), XXXII), erige como princípio da ordem econômica a defesa do consumidor (C.F.art.170, V). E, para que o Estado cumprisse sua função de legislar sobre a responsabilidade por dano ao consumidor, estabelece a competência concorrente da União, dos Estados e do Distrito Federal nessa matéria (C.F.art.24, VIII). Verifica-se, desse modo, que, tanto para a proteção e a defesa da saúde, quanto para a atribuição da responsabilidade por dano, ao consumidor, seguiu-se um só critério adotado para fixar a competência legislativa. Isso significa que, a competência da União se deve limitar ao estabelecimento das normas gerais, cabendo aos Estados e aos Municípios suplementá-las (art.24,\$s1£ e 2^c/c art.30,II).

Editado com o caráter de norma geral nacional, em obediência ao que ficou determinado no artigo 48, do Ato das Disposições Constitucionais Transitórias (não respeitando, porém, o prazo previsto, de 120 dias após a promulgação da Constituição), o Código de Proteção e Defesa do Consumidor foi implementado por meio da Lei federal n 8.078, de 11 de setembro de 1990. Trata-se de uma regra geral, aplicável a todo o território nacional, para disciplinar as relações de consumo. É importante notar que, em seu caráter de Lei-quadro, o Código do Consumidor se preocupa em construir uma nova cultura de respeito ao consumidor, o elo mais fraco na relação de consumo. Assim, já em seu primeiro artigo, essa Lei reafirma sua aplicabilidade a toda a ordem pública e declara ser seu intuito proteger e defender o consumidor. E, a fim de promover o respeito à dignidade, à saúde e à segurança e proteger os interesses econômicos do consumidor, bem como, promover a melhoria da qualidade de vida, a transparência e a harmonia das relações de consumo, institui a Política Nacional de Relações de Consumo (art. 4e).

Por qualquer ângulo que se a examine, fica evidente, sempre, ser o grande objetivo da Lei federal ne 8.078/90 instaurar essa nova cultura
Código de Proteção e Defesa do Consumidor, Lei federal ne 8.078, de 11 de setembro de 1990 
Sistema Nacional de Defesa do Consumidor, Decreto federal ne 2.101, de 20 de março de 1997

fiscais do órgão de proteção e defesa do consumidor no Brasil. Para tanto, são reforçados os comportamentos educativos, e muitas das definições constantes ủessa Lei têm sobretudo tal intuito. É o caso, por exemplo, da obrigação de o governo incentivar a criação e o desenvolvimento de associações representativas do consumidor; da necessidade de educação e de informação de fornecedores e consumidores (art.4e,II,b e IV); da caracterização do produto defeituoso (art.12, \$s 1e e 2e): da disciplina da responsabilidade (arts. 12 a 25 e 101 e 102).

O Código do Consumidor, segundo a sua característica de norma geral e a necessidade de implantação dessa cultura de proteção e defesa do consumidor, criou o Sistema Nacional de Defesa do Consumidor, integrado por órgãos federais, estaduais e municipais e por entidades privadas de defesa do consumidor (art.105). Isso significa, por exemplo, que os órgãos de Vigilância Sanitária, em qualquer das esferas de governo, devem integrar o Sistema Nacional de Defesa do Consumidor. Tal é a opinião de FINK, que ao analisar o Decreto federal ne 2.101, de 20 de março de 1997, que organiza esse sistema, afirma ser recomendável a integração dos órgãos de Vigilância à Saúde, inclusive, com os órgãos diretos de defesa do consumidor, para que os primeiros levem em conta a visão dos consumidores, em sua atuação. ${ }^{19}$ Essa integração tem, portanto, caráter educativo. Mas também é indispensável ao órgão de defesa do consumidor o exercício do poder de polícia. Isso porque, por exemplo, no caso da Vigilância à Saúde, "o órgão de defesa do consumidor não é dotado do poder de polícia"20, e necessita, assim, notificar os órgãos competentes, sejam federais, estaduais ou municipais, para serem adotadas as medidas cabíveis. É claro que, havendo alguma forma de convênio destinada a ampliar as atribuições de polícia desses órgãos, tal ampliação é sempre possível. Com efeito, caso a Vigilância Sanitária de determinado município deseje incluir entre seus fiscais aqueles do órgão de proteção e defesa do consumidor, criado naquele município, isso será possível sempre que houver acordo formal entre ambas as partes. Contudo, é indispensável reconhecer que houve a imposição legal (esclarecida no artigo 72 do Decreto federal n².101/97) de um poder-dever de fiscalização das relações de consumo aos órgãos públicos, no âmbito de sua competência, para fiscalizarem as relações de consumo e autuarem os responsáveis por práticas que violem os direitos do consumidor.

Finalmente, prevendo-se a eventualidade de conflito de atribuições, sempre possível quando se alarga a esfera de atuação de órgãos

\footnotetext{
19 FINK, D. R., 1988. In VVAA Código brasileiro de defesa do consumidor. Rio de Janeiro: Forense. 5 a edição. pág. 751

20 Cf. FINK, D. R. ob. cit. pág. 753
} 
públicos, é necessário lembrar que tal conflito não se configura - no sistema jurídico brasileiro - em face de atribuições estabelecidas por decreto. De fato, apenas a lei pode criar, modificar ou extinguir direito. Portanto, uma atribuição de função feita por lei a determinado órgão sempre deverá prevalecer sobre outra, decorrente de decreto (ato administrativo, portantol para outro. Quando, por outro lado, o conflito derivar de atribuições conferidas, por decreto, entre diferentes órgãos do governo federal, existe previsão normativa designando o Departamento de Proteção e Defesa do Consumidor para dirimí-lo (Decreto federal ne $2.101 / 97$, art. 5 e $\$$ ún.). O interesse do legislador, ao estabelecer o Sistema Nacional de Defesa do Consumidor, contudo, longe de provocar disputas por atribuições, foi instituir uma nova cultura de proteção e defesa do elo mais fraco da relação de consumo: o consumidor. Entretanto, quando não for possível evitar o conflito de atribuições nesse tema, será necessário recorrer ao Poder Judiciário.

\section{Referências bibliográficas}

DALlARI, Dalmo de Abreu. Elementos de Teoria Geral do Estado. São Paulo: Saraiva. 20a Edição.

DA SILVA, José Afonso, 1998. Curso de Direito Constitucional Positivo. São Paulo: Revista dos Tribunais.

DI PIETRO, Sylvia Zanella, 1998. Direito Administrativo. São Paulo: Atlas.

DALLARI, Sueli Gandolfi et all, 1992. O Conceito Constitucional de Relevância Pública. Organização Panamericana da Saúde. Série Direito e Saúde, 1.

DALLARI, Sueli Gandolfi, 1995. Os Estados Brasileiros e o Direito à Saúde. São Paulo: HUCITEC. 



\section{Epidemiologia}

\section{Conteúdo}

Definição, objetivos, abrangência e aplicações da Epidemiologia. Causalidade. Medidas. Tipos de Estudos. Sistemas de Vigilância de doenças.

A leitura deve permitir:

- Conhecer os principais elementos constituintes do campo conceitual da Epidemiologia, com ênfase: na determinação social e múltipla das doenças; nos critérios de validação causal e no papel da estatística; e na desigualdade como condição geradora de diferentes padrões de morbidade e mortalidade; incorporar esses elementos à reflexão cotidiana e, assim, ampliar as ações de Vigilância Sanitária para além do campo da regulação e da fiscalização.

- Interpretar as medidas de freqüência de doenças e de eventos adversos - incidência e prevalência - e os principais indicadores de morbidade e mortalidade.

- Definir os conceitos essenciais empregados em estudos e investigações epidemiológicas - fator de risco, risco, variável, indicador, medida, coeficiente, proporção, amostra, validade, confiabilidade, epidemia, surto, odds ratio, risco relativo, erro, condição traçadora e evento sentinela - a um nível de profundidade que permita ao profissional participar de sistemas de Vigilância e de monitoramento de agravos à saúde, e desenvolver ações conjuntas com os órgãos de Vigilância Epidemiológica.

- Compreender os principais delineamentos metodológicos, bem como as medidas de risco correspondentes, de forma a se compreender a produção científica da disciplina e a se identificarem órgãos e grupos de pesquisa epidemiológica. 
- Conhecer os objetivos e as características dos sistemas de Vigilância como atividade de monitoramento, com ênfase especial nas distinções entre as Vigilâncias ativa e passiva, e no reconhecimento da aplicação das mesmas em situações concretas. 


\section{Epidemiologia}

Guido Palmeira

\section{A Epidemiologia}

A Epidemiologia estuda o processo saúde-doença em populaçōes humanas, com o objetivo de prevenção e controle. Cabe à Epidemiologia encontrar respostas para as seguintes questões:

1) Como a doença se distribui segundo as características das pessoas, dos lugares que elas habitam e da época considerada?

2) Que fatores determinam a ocorrência da doença e sua distribuição na população?

3) Que medidas devem ser tomadas a fim de prevenir e controlar a doença? Como devem ser conduzidas?

4) Qual o impacto das ações de prevenção e controle sobre a distribuição da doença?

A referência à população caracteriza a Epidemiologia, e a distingue da clínica (cujo interesse é a doença nos indivíduos). Essa característica aproxima a Epidemiologia de outras disciplinas cujo objeto também tem caráter coletivo.

O termo população designa, originalmente, o conjunto de habitantes de um território (região, país, cidade, bairro) e, por extensão, qualquer fração - subpopulação - desta (a população feminina de uma cidade, a de crianças de um país, a de doentes de uma região, etc).

As características das populações - tamanho, dinâmica de entrada e saída de indivíduos (nascimentos, mortes, movimentos migratórios), estrutura (distribuição dos indivíduos segundo idade e sexo), densidade (distribuição espacial dos indivíduos) - são objeto da demografia. Do ponto de vista da demografia, as populações são entidades reais, com organização e dinâmicas próprias, não se confundem com o simples so- 
História Natural

da Doença matório de indivíduos independentes, e estão em constante movimento, em evolução permanente.

O termo "população" tem sido empregado, em biologia, para designar um conjunto de indivíduos da mesma espécie, que vivem em um determinado território (população de anofelinos em um bairro, de roedores em uma cidade). Embora os estudos epidemiológicos possam, eventualmente, envolver outras populações (vetores, reservatórios), o objeto central da Epidemiologia diz respeito às populações humanas. Desde que as populações humanas estão constituídas como sociedades, e que os costumes, as normas e a estrutura das sociedades afetam tanto a dinâmica populacional quanto a distribuição das doenças, é necessário o epidemiologista levar em consideração o conhecimento produzido no campo das ciências sociais (sociologia, antropologia, economia, etc).

Os elementos das populações humanas (os indivíduos) não são idênticos, mas ao contrário, admitem uma ampla variação quanto a diversas características. Também não é necessário haver continuidade territorial para caracterizar uma população (a população de brasileiros inclui os que estão fora do país, e não se confunde com a população das pessoas que residem no Brasil, que inclui os imigrantes estrangeiros). $\mathrm{O}$ que define uma população é uma característica comum, compartilhada por todos os seus elementos (o fato de ser brasileiro, o fato de morar no Brasil, etc).

Para estudar as características de uma população, tanto a demografia quanto a Epidemiologia recorrem à estatística. Do ponto de vista da estatística, qualquer conjunto definido por um predicado comum pode ser tratado como uma população, independente da natureza dos elementos (pessoas, animais, objetos, instituições, documentos, acontecimentos). Além de orientar a análise de dados populacionais, os métodos estatísticos permitem o estudo de populações muito grandes e de populações infinitas (todos os possíveis lançamentos de uma moeda) a partir de uma amostra, um subconjunto "representativo" do conjunto inteiro.

O processo saúde-doença e o objetivo de prevenção e controle completam a caracterização de Epidemiologia.

Para prevenir e controlar a doença é necessário conhecer, tanto quanto possível, os elementos que participam do processo de adoecimento e os fatores que determinam a distribuição da doença segundo o tempo, o lugar e as pessoas que adoecem. O modelo genérico da "História Natural da Doença" relaciona as diversas ações de prevenção e controle a diferentes momentos do processo de adoecimento (Figura 1).

A interação entre vários fatores de natureza diversa (climáticos, biológicos, ecológicos, fisiológicos, imunológicos, sociais, culturais, eco- 
Figura 1 História natural da doença e niveis de prevenção

\section{História natural da doença}

\section{Pré-patogênese}

Inter-relacionamento entre as

condiçōes prévias ao adoecimento:

$$
\text { - raça - moradia - clima }
$$

- comportamento $\cdot$ agentes patógenos

- hábitos alimentares - saneamento

- trabalho - produtos consumidos

- renda • acesso a serviços • sexo

-perfil imunológico • idade

- higidez - vetores

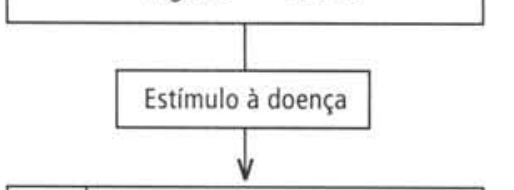

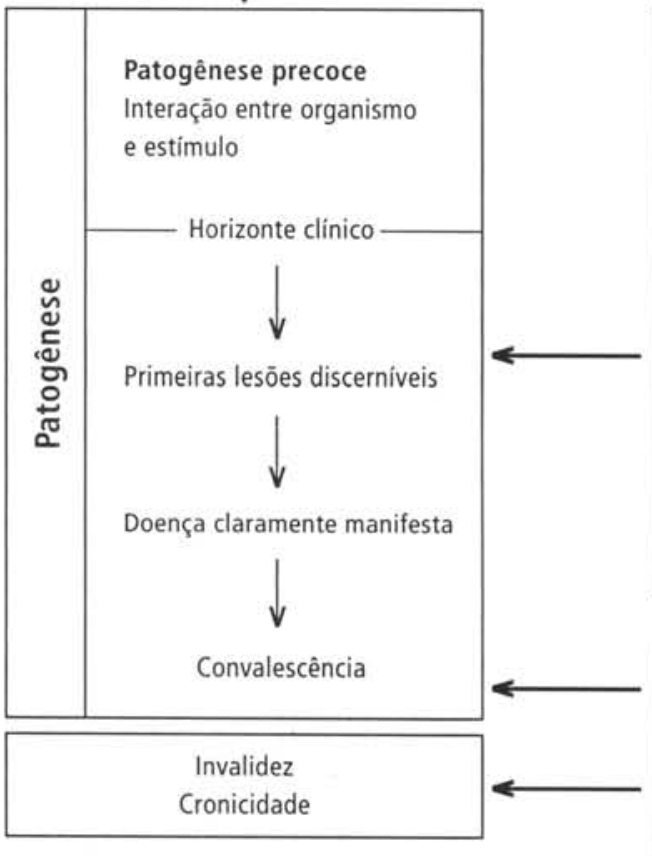

Patogênese precoce

Interação entre organismo

e estimulo

Horizonte clínico

\section{discerniveis}

Doença claramente manifesta

Cronicidade

\section{Ações de prevenção e controle}

\section{Primária}

\section{Promoção da saúde}

Combate à miséria e à pobreza

Moradia e trabalho adequados

Educação básica

Saneamento ambiental

Proteçāo da saúde

Vigilância de riscos ambientais

Vigilância de riscos ocupacionais

Vigilância sanitária de produtos

Vigilância sanitária de serviços

Vigilância Epidemiológica

Controle de vetores e reservatórios

Assistência à saude

Imunização

\section{Secundária}

\section{Diagnóstico precoce}

e pronto-atendimento

Vigilância de serviços

Vigilância de produtos

Vigilância Epidemiológica

Exames periódicos

Assistência médica

Limitação da invalidez

Assistência médica

Vigilância de serviços

Vigilância de produtos

\section{Terciária}

\section{Reabilitação}

Assistência médica

Vigilância de serviços

Vigilância de produtos

Assistência social

Reeducação e treinamento 
nômicos, etc.), sob condições que se modificam segundo o lugar, o momento e a população considerada (as pessoas), e que resulta num "estímulo à doença", corresponde ao período de pré-patogênese (anterior ao adoecimento do homem).

O período de patogênese tem início com a primeira interação do estímulo patogênico com o organismo do homem, antes de qualquer manifestação perceptível da doença (patogênese precoce). O horizonte clínico marca o aparecimento de distúrbios de forma e função, produtores dos sinais e sintomas que permitem perceber a doença; seguem-se os momentos de doença manifesta e de convalescença. O processo de patogênese pode resultar em recuperação (restabelecimento do equilíbrio), cronificação, invalidez ou morte.

O objetivo da prevenção é interromper o processo de adoecimento. No período de pré-patogênese cabem as ações de promoção e proteção da saúde (prevenção primária). No início do período de patogênese a prevenção consiste no diagnóstico precoce, no pronto atendimento e na limitação dos danos e seqüelas, através do tratamento adequado (prevenção secundária). Durante a convalescença, e na eventualidade de cronificação ou invalidez, têm lugar as medidas de reabilitação (prevenção terciária).

Uma das atividades tradicionais da Epidemiologia é a investigação dos elementos que participam da pré-patogênese, e de suas inter-relações. Em alguns casos (doenças infecciosas, intoxicações) é possível identificar um agente etiológico específico (causa necessária), em outros se procura estabelecer a probabilidade de adoecer associada a determinados fatores de risco. ${ }^{1}$ Dada a multiplicidade e a diversidade de elementos envolvidos na pré-patogênese de qualquer doença, e a complexidade das relações entre eles, mesmo quando existe um agente etiológico específico e conhecido, será sempre necessário compreender a doença como resultante de um processo "multicausal".

Observe-se que, freqüentemente, os fatores envolvidos na ocorrência da doença nos indivíduos tomados isoladamente los determinantes do adoecimento de um paciente específico, em um momento determinado) não se confundem com os determinantes da distribuição da doença na população.

Uma segunda tarefa reservada à Epidemiologia é a descrição das condições de saúde de populações reais, com vistas à orientação das ações de prevenção primária, à identificação de grupos especialmente

\footnotetext{
${ }^{1} \mathrm{Um}$ fator de risco é um atributo, de uma população, cuja presença está associada à maior incidência de uma doença, um atributo associado à maior probabilidade de ocorrência da doença.
} 
suscetiveis e de circunstâncias que favorecem a disseminação da doença; nessa tarefa se incluem o monitoramento dos riscos (Vigilância Sanitária e Ambiental) e da ocorrência da doença (Vigilância Epidemiológica).

Finalmente, a Epidemiologia tem sido empregada na avaliação de técnicas e procedimentos de prevenção secundária e terciária: avaliação do impacto das medidas preventivas e da qualidade dos serviços (assistenciais) prestados; testagem da eficácia e da segurança de medicamentos, produtos e procedimentos terapêuticos; avaliação da validade e da confiabilidade de procedimentos de diagnóstico (que permitem reduzir o período de patogênese precoce).

\section{Matriz de dados}

Os estudos epidemiológicos são protocolos que permitem sistematizar as observações sobre a ocorrência (a distribuição) da doença; definem os critérios para medir e comparar essa ocorrência (em diferentes populações, na mesma população em diferentes momentos, em diferentes subpopulações de uma mesma população, em grupos populacionais específicos, etc.) e estabelecem os requisitos para que se reconheça a existência de associação entre a ocorrência da doença e as características populacionais.

As observações sistematizadas constituem os dados do estudo. O conjunto de dados é organizado sob forma de uma (ou mais) matriz de dados (Quadro 1).

A definição dos componentes da(s) matriz(es) de dados, uma das etapas iniciais de qualquer atividade em Epidemiologia, exige extrema atenção, pois tem grande repercussão sobre todas as etapas posteriores.

As unidades de análise são os indivíduos que pertencem à(s) população(ões) em estudo. Definir a unidade de análise significa estabelecer unidades de análise
Quadro 1 Matriz de dados

\begin{tabular}{|l|c|c|c|c|}
\hline \multirow{2}{*}{$\begin{array}{l}\text { Unidade } \\
\text { de análise }\end{array}$} & \multicolumn{4}{|c|}{ Variáveis } \\
\cline { 2 - 5 } & Idade & Sexo & Peso & Escolaridade \\
\hline \multirow{2}{*}{ Sujeito 1 } & $I_{1}$ & $S_{1}$ & $P_{1}$ & $E_{1}$ \\
Sujeito 2 & $I_{2}$ & $S_{2}$ & $P_{2}$ & $E_{2}$ \\
Sujeito 3 & $I_{3}$ & $S_{3}$ & $P_{3}$ & $E_{3}$ \\
Sujeito $N$ & $I_{n}$ & $S_{n}$ & $P_{n}$ & $E_{n}$ \\
\hline
\end{tabular}


os atributos que delimitam um conjunto (a população alvo). A definição deve permitir a discriminação clara e precisa entre os elementos que pertencem e os que não pertencem ao conjunto especificado.

As variáveis correspondem aos atributos das unidades de análise que admitem variação. A definição de variáveis constitui um recurso para sujeitar um conceito a uma medida. O indicador, representante da variável, sujeito à verificação empírica, é o elemento que permite, através da medida ${ }^{2}$, classificar as unidades de análise segundo as distintas categorias que a variável admite.

A natureza das categorias da variável impõe limites à maneira de lidar com os dados, de efetuar as operações necessárias para descrever e comparar as características populacionais que a variável procura expressar. Vejamos:

-variáveis nominais: possuem categorias de natureza qualitativa, expressam-se nominalmente e resultam de um processo de classificação (sexo, raça, religião, estado civil, tipo de doença, causa de morte). As operações usuais de aritmética não podem ser feitas com este tipo de variável.

- variáveis ordinais: possuem categorias de natureza qualitativa, e uma ordem natural, embora não seja possível determinar a magnitude das diferenças entre elas; resultam de um processo de ordenação (escolaridade, nível sócio-econômico, etc). Neste caso só podem ser feitas operaçōes do tipo "maior do que" ou "menor do que", e as demais operações aritméticas continuam a ser impossíveis.

- variáveis discretas: possuem categorias de natureza quantitativa, que se expressam, exclusivamente, por números inteiros (qualquer intervalo finito da escala sempre define um conjunto finito de valores); resultam de um processo de contagem (número de filhos, número de consultas, etc.).

- variáveis contínuas: possuem categorias de natureza quantitativa que se expressam através de escalas que admitem valores fracionários (podem ser definidos infinitos valores em qualquer intervalo finito da escala, através de sucessivas reduções da ordem de grandeza), resultam de procedimentos de medida (estatura, peso, pressão arterial, glicose sangüínea, temperatura, períodos de tempo, taxas e coeficientes em geral, etc).

As variáveis quantitativas, tanto as discretas quanto as contínuas, admitem quaisquer operações aritméticas.

2 O termo "medida" está empregado aqui (e será empregado, freqüentemente, ao longo do texto) em um sentido ampliado, como referência a procedimentos de classificação, ordenação, contagem e medição. 
Definir uma variável significa descrever, clara e explicitamente, os indicadores que a representam, as categorias que a mesma admite, e os procedimentos e a unidade de medida utilizados. A definição operativa permite que um certo fenômeno seja igualmente classificado por qualquer observador que use a mesma definição. Por outro lado, reduzir um conceito a uma medida implica em sua distorção. Em alguns casos, a distorção provocada pelo processo de redução tem como conseqüência a perda do objeto original; isto é, aquilo que o pesquisador está medindo não tem mais correspondência com o que o conceito original expressa.

Ao definir operacionalmente uma variável, o pesquisador deve cuidar para que suas categorias sejam, ao mesmo tempo, mutuamente exclusivas (um mesmo indivíduo não pode ter atributos que permitam classificá-lo em mais de uma categoria da mesma variável) e exaustivas (nenhuma unidade de análise pode deixar de ser classificada). Para garantir que uma escala nominal seja exaustiva, é necessário incluir, freqüentemente, categorias do tipo 'ignorado', 'outros', 'indefinido', etc. Como regra geral, é recomendável observar as definições operativas de uso corrente, e/ou que aparecem em outros estudos, de modo a se viabilizarem comparações.

Quando são utilizados dados primários (colhidos diretamente pelo próprio pesquisador), a definição operativa de uma variável deve levar em conta a disponibilidade de recursos financeiros e humanos, a operacionalidade dos procedimentos de medida (grau de sofisticação dos instrumentos, questionários, exames laboratoriais, etc.) e o tempo necessário para a coleta de dados. Quando são utilizados dados de registros preexistentes, colhidos por pessoas alheias à investigação (dados secundários), é necessário respeitar os limites das definições operativas empregadas no sistema de registro original.

Em alguns casos (geralmente quando a.variável é qualitativa) a definição das categorias é imediata, pois os predicados que permitem identificá-las são espontâneos, e em pequeno número (sexo: masculino e feminino, estado civil: solteiro, casado, viúvo, desquitado; etc.). Em outros, embora os predicados também sejam espontâneos, será necessário arranjá-los de modo a evitar um número excessivo de categorias, o que pode prejudicar a análise estatística dos dados (insuficiência cardíaca, hipertensão arterial, doença isquêmica do coração e doença cerebrovascular podem ser agrupadas na categoria "doenças do aparelho cardiovascular"). O fato de as categorias serem espontâneas não dispensa uma definição operativa clara e precisa.

As categorias das variáveis quantitativas (principalmente as de tipo contínuo) geralmente são arranjadas em intervalos de classes (menor de 1 ano, de 1 a 4 anos, de 5 a 9 , de 10 a $14, \ldots, 45$ a 49,50 anos de idade e definição operativa de variável 
mais). Neste caso, é importante observar que os valores reunidos na classe assumirão o valor médio do intervalo (a média aritmética entre os extremos da classe). Conseqüentemente, quanto maior a amplitude da classe, maiores as probabilidades de ser introduzido erro, uma vez que as diferenças entre os valores realmente medidos e o valor médio do intervalo serão desconsideradas. ${ }^{3}$

Por um lado, se deve preferir classes de pequena amplitude, por outro é necessário cuidar para que a quantidade de categorias não seja muito grande. As classes podem ter limites fechados ou abertos (do tipo '50 anos e mais'), mas devem ser mutuamente exclusivas. É útil as classes terem amplitude uniforme, embora em alguns casos seja necessário definir classes de diferentes amplitudes, a fim de preservar aspectos relevantes da distribuição.

Em um estudo sobre o perfil do risco de doença cardiovascular em funcionários de uma instituição bancária ${ }^{4}$, a autora definiu como população alvo (conjunto das unidades de análise) os "funcionários em atividade nos Centros de Processamento e Serviços de Comunicações e Órgãos da Direção Geral, no Estado do Rio de Janeiro, no ano de 1994." O Quadro 2 resume a definição operativa de algumas das variáveis utilizadas. Observe que:

- um único conceito (hipertensão) pode ser expresso por mais de uma variável (informado sobre hipertensão e hipertenso segundo medida direta).

- uma medida contínua (índice de massa corporal) pode ser expressa através de categorias nominais (baixo peso, normal, sobrepeso, obeso).

- algumas variáveis (informado sobre hipertensão, hipertenso segundo medida direta) são binárias, isto é, só admitem duas categorias possíveis: sim ou não (genericamente 0 ou 1 ).

- uma variável binária (hipertenso x não-hipertenso) pode ser definida através de um ponto de corte em uma escala contínua (160 ou 95 $\mathrm{mmHg}$ na escala da PA).

- a definição de uma categoria (hipertenso segundo medida direta) pode envolver a combinação de mais de uma "medida" (PA em mmHg e declaração sobre tratamento específico).

- alguns indicadores (freqüência relativa do consumo semanal de 11 tipos de alimento) correspondem a uma proporção (freqüência de-

\footnotetext{
${ }^{3}$ A série de medidas de idade em anos $10,13,12,10,10,14,11,14,10$, por exemplo, agrupada na classe de 10 a 14 anos, será "lida" como uma série de nove medidas de valor 12 (o ponto médio do intervalo). ${ }^{4} \mathrm{CHOR}, \mathrm{D}$. Perfil de risco cardiovascular de funcionários de banco estatal. Tese apresentada à Faculdade de Saúde Pública da Universidade de São Paulo para a obtenção de grau de Doutora em Saúde Pública. São Paulo, 1997.
} 
Quadro 2 Definições operativas de variáveis

\begin{tabular}{|c|c|c|c|}
\hline Variável & Indicador (es) & Medida & Categorias \\
\hline $\begin{array}{l}\text { Informado } \\
\text { sobre } \\
\text { hipertensão }\end{array}$ & $\begin{array}{l}\text { Perguntas: "Algum profissional } \\
\text { de saúde lhe informou que você } \\
\text { tinha pressão alta? Você é ou } \\
\text { foi portador de hipertensão? } \\
\text { Você está em tratamento } \\
\text { especifico para controle de } \\
\text { hipertensāo arterial?" }\end{array}$ & $\begin{array}{l}\text { Classificação (qualitativa) } \\
\text { segundo o caráter afirmativo } \\
\text { ou negativo das respostas. }\end{array}$ & $\begin{array}{l}\text { Sim = resposta afirmativa a } \\
\text { pelo menos uma das questōes. } \\
\text { Não = respostas negativas } \\
\text { a todas as questōes. }\end{array}$ \\
\hline $\begin{array}{l}\text { Hipertenso } \\
\text { segundo } \\
\text { medida } \\
\text { direta }\end{array}$ & $\begin{array}{l}\text { Segunda medida da PA, aferida } \\
\text { de acordo com procedimento } \\
\text { padronizado, por examinadores } \\
\text { treinados, utilizando esfignoma- } \\
\text { nômetros iguais e especialmen- } \\
\text { te preparados. } \\
\text { Pergunta: "Você está em } \\
\text { tratamento de hipertensão?" }\end{array}$ & $\begin{array}{l}\text { Valores da PA sistólica } \\
\text { e diastólica em mmHg. } \\
\text { Classificação (qualitativa) } \\
\text { segundo o caráter afirmativo } \\
\text { ou negativo das respostas. }\end{array}$ & $\begin{array}{l}\text { Sim = PA igual ou superior } \\
\text { a } 1 \text { b0 (sist.) ou } 95 \text { (diast.), } \\
\text { ou individuo que declarou } \\
\text { estar em tratamento especifico. } \\
\text { Não = PA menor que } 160 \text { ou } 95 \text {, } \\
\text { em individuo que negou estar } \\
\text { em tratamento especifico. }\end{array}$ \\
\hline $\begin{array}{l}\text { Hábito } \\
\text { de fumar }\end{array}$ & $\begin{array}{l}\text { Declaração do funcionário sobre } \\
\text { a quantidade de cigarros fuma- } \\
\text { dos atualmente ou no passado. }\end{array}$ & $\begin{array}{l}\text { Ordenação (qualitativa) segun- } \\
\text { do a quantidade (média) decla- } \\
\text { rada de cigarros consumidos. }\end{array}$ & $\begin{array}{l}\text { Não fumante = nunca fumou ou } \\
\text { não chegou a fumar pelo menos } \\
5 \text { carteiras ao longo da vida. } \\
\text { Fumante leve = admitiu fumar } \\
\text { até } 20 \text { cigarros por dia. } \\
\text { Grande fumante = admitiu } \\
\text { fumar mais de } 20 \text { cigarros/dia. } \\
\text { Ex-fumante = parou de fumar } \\
\text { a pelo menos um ano. }\end{array}$ \\
\hline $\begin{array}{l}\text { Índice } \\
\text { de massa } \\
\text { corporal }\end{array}$ & $\begin{array}{l}\text { Quociente entre o peso e o } \\
\text { quadrado da estatura (aferidos } \\
\text { por examinadores treinados } \\
\text { e instrumentos padronizados) } \\
\text { expresso em } \mathrm{kg} / \mathrm{m}^{2} \text {. }\end{array}$ & $\begin{array}{l}\text { Peso medido em quilos. } \\
\text { Estatura medida em metros. }\end{array}$ & $\begin{array}{l}\text { Baixo peso = IMC menor que } 20 \\
\text { Normal = IMC igual ou maior } \\
\text { que } 20 \text { e menor ou igual a } 24,9 \\
\text { Sobrepeso = IMC igual ou maior } \\
\text { que } 25 \text { e menor ou igual a } 30 \\
\text { Obeso = IMC maior que } 30\end{array}$ \\
\hline
\end{tabular}


Quadro 2 (continuação)

\begin{tabular}{llll} 
Variável & Indicador (es) & Medida & Categorias \\
\hline Escore & Freqüência relativa do consumo & Escala ordinal de pontos: & Variável continua, pode assumir \\
alimentar & semanal de 11 tipos de alimen- & $0=$ ausência de consumo, & (como toda proporção) qualquer \\
& to (quociente multiplicado por & $1=$ menos de uma vez, & valor entre zero e 1. \\
& 100 entre o total de pontos & $2=$ de uma a três vezes, & \\
& obtidos e o máximo de pontos & $3=$ mais de três vezes & \\
& possiveis, desprezados os itens & por semana. &
\end{tabular}

clarada do consumo dos alimentos em relação à freqüência máxima possivel).

- alguns indicadores (índice de massa corporal) correspondem à relação entre duas medidas de natureza distintas (peso e altura).

Não existem receitas! Para definir operacionalmente as variáveis; o pesquisador deve considerar tanto os princípios gerais de categorização quanto os objetivos do estudo, e explorar sua própria sensibilidade.

\section{Indicadores de saúde}

A mensuração do estado de saúde de uma população se faz negativamente, através da freqüência de eventos que expressam a "não-saúde": morte (mortalidade) e doença (morbidade). Assim, a quantidade de pessoas que morrem e a quantidade de pessoas que adoecem, em uma determinada população, durante um determinado período, são usadas como medida da saúde daquela população, naquele período.

O número absoluto de pessoas que morrem e adoecem são medidas cujo significado está limitado ao tempo e à população considerados. ${ }^{5}$ A comparação de medidas de mortalidade, ou de morbidade, de diferentes populações (ou da mesma população em diferentes momentos) requer a transformação da mesma em valores relativos, requer a

\footnotetext{
5 Os valores absolutos têm importância para o planejamento e a gerência.
} 
ponderação das medidas. Os indicadores de saúde são medidas relativas de mortalidade e de morbidade, estão sempre referidos a uma população específica e a um intervalo de tempo determinado; correspondem a quocientes (frações), que assumem dois formatos genéricos: ${ }^{6}$

- coeficientes são quocientes em que o número absoluto de eventos ocorridos em uma população específica, durante um período determinado - o numerador - é ponderado pelo total de eventos da mesma espécie teoricamente possiveis, o denominador. ${ }^{7}$

- proporções são quocientes que expressam a parcela dos eventos que possui um certo atributo ou característica específica - o numerador - em relação ao total de eventos da mesma natureza ocorridos na população e no período considerados, o denominador. ${ }^{8}$

Os indicadores de saúde expressam numericamente o estado da saúde de uma população, em um determinado momento. A comparação de indicadores de saúde de diferentes populações permite distinguir diferenças nos padrões de morbidade e de mortalidade, que refletem diferenças econômicas e sociais.

Quando construídos segundo critérios geográficos, ou geopolíticos, os indicadores de saúde tornam evidentes, de modo formal e claro, as desigualdades entre países, cidades ou regiões. Se as populações forem definidas em função do espaço social que os seus elementos ocupam, os indicadores permitirão evidenciar as desigualdades sociais entre grupos do mesmo espaço geográfico.

\section{Mortalidade}

O número absoluto de óbitos ocorridos em uma determinada população, durante um certo período, ponderado pelo tamanho da população, no meio do período, é o coeficiente geral de mortalidade ${ }^{9}$ dessa população, no período considerado.

Como a informação fornecida pelo coeficiente geral de mortalidade é limitada, a análise da mortalidade de uma população requer a construção de indicadores específicos, que forneçam informação a respeito de quem morre, e sobre as causas dos óbitos.

\footnotetext{
6 Os termos "taxa", "proporção", "índice", "coeficiente", costumam ser empregados indistintamente, segundo diferentes autores ou circunstâncias, para designar um ou outro formato de quociente.

7 Os coeficientes costumam ser números pequenos (o denominador costuma ser muito maior do que o numerador). É praxe multiplicá-los por uma potência de $10\left(10^{\mathrm{n}}\right)$, a fim de apresentá-los sob um formato mais "assimilável" (em geral um número >1).

8 As proporções são usualmente apresentadas na forma de percentagens ( $x 100)$.

9 O CGM costuma ser multiplicado por 1.000 .
}

\section{coeficientes}

proporçōes

coeficiente geral de mortalidade 


$$
\mathrm{CGM}=\frac{\begin{array}{c}
\text { total de óbitos ocorridos } \\
\text { na população durante o período }
\end{array}}{\text { população total no meio do período }} \times 1.000
$$

Os indicadores específicos de mortalidade segundo as características das pessoas que morrem (idade, sexo, raça, ocupação, renda, etc.) assumem os formatos genéricos já descritos:

Coeficiente de mortalidade específico das pessoas com o atributo "a", em uma população específica, durante um determinado período:

ne de óbitos de pessoas com o atributo

$$
\begin{aligned}
& \mathrm{CM}_{\mathrm{a}}=\frac{\text { "a" na população e no período }}{\text { total de pessoas com o atributo "a" }} \times 1.000 \\
& \text { na população, no meio do período }
\end{aligned}
$$

Mortalidade proporcional das pessoas com o atributo "a", em uma população específica, durante um determinado período:

n de óbitos de pessoas com o atributo

$$
\mathrm{MP}_{\mathrm{a}}=\frac{\text { "a" na população e no período }}{\begin{array}{c}
\text { total de óbitos na população } \\
\text { durante o período }
\end{array}} \times 100
$$

mortalidade infantil

\subsection{Mortalidade segundo a idade}

A idade das pessoas que morrem constitui informação de grande relevância na análise da mortalidade. A mortalidade infantil é um indicador tradicional da qualidade de vida e das condições de saúde de uma população; diz respeito aos óbitos de crianças menores de 1 ano e admite dois componentes: mortalidade neonatal (crianças até 28 dias) e mortalidade infantil tardia (crianças entre 28 dias e 1 ano). Os coeficientes de mortalidade infantil empregam como denominador (ponderador) o número de nascidos vivos na população, durante o período considerado. 
Coeficiente de mortalidade infantil de uma população especí-

fica, durante um período determinado:

óbitos de menores de 1 ano ocorridos

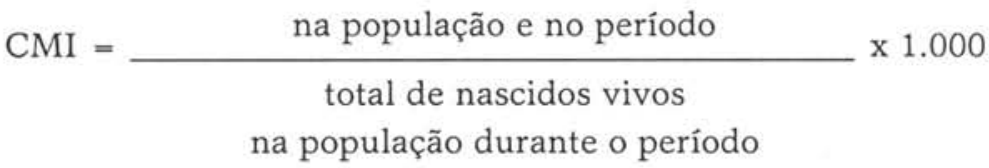

Outro modo de estudar a mortalidade segundo a idade, é construir indicadores que expressem a proporção de óbitos de diferentes faixas etárias (numerador), em relação ao total de óbitos ocorridos na população, no período considerado (denominador). Além de alto poder para discriminar as condições de vida e saúde, os indicadores de mortalidade proporcional são fáceis de calcular, e dispensam dados populacionais.

mortalidade proporcional

Razão de mortalidade proporcional dos maiores de 50 anos (indicador de Swaroop e Uemura):

óbitos de pessoas de 50 anos ou mais

$$
\mathrm{RMP}=\frac{\text { ocorridos na população e no período }}{\text { total de óbitos na população e no período }} \times 100
$$

A curva de mortalidade proporcional (de Nelson Moraes) é uma representação gráfica da mortalidade proporcional de grupos etários predefinidos: <de 1 ano, 1 a 4 anos, 5 a 19 anos, 20 a 49 anos e 50 anos ou mais. As curvas das populações com piores condições de saúde mostram alta proporção de óbitos infantis e de pré-escolares; em situações muito precárias, a proporção de óbitos na faixa de 20 a 49 anos também é elevada (poucas pessoas chegam a completar 50 anos). Populações mais saudáveis exibem curvas que refletem menores proporções de óbitos infantis e escolares, com predomínio crescente dos óbitos em maiores de 50 anos (Figura 2).

\subsection{Mortalidade segundo a causa}

Um segundo aspecto importante na análise da mortalidade diz respeito às condições patológicas que levam à morte. A definição da variável "causa da morte" costuma ter como referência a declaração de 
Figura 2 Curvas de mortalidade proporcional e nivel de saúde

Muito baixo

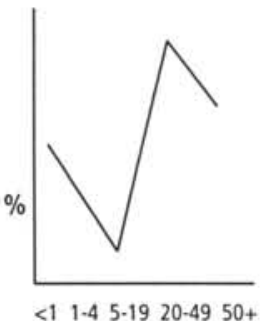

Baixo

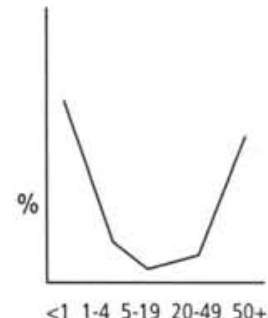

Regular

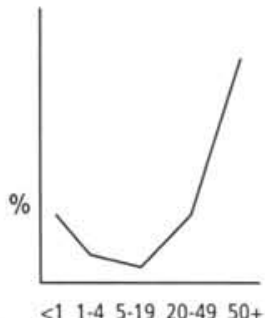

Elevado

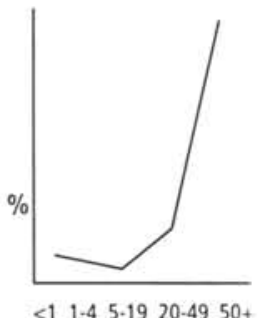

óbito (registro civil). ${ }^{10} \mathrm{O}$ critério de classificação (o indicador) pode limitar-se à "causa básica da morte" (doença ou estado mórbido que provocou diretamente o óbitol ou considerar também as causas antece. dentes (estados mórbidos que produziram a "causa básica") e contribuintes (outros estados patológicos significativos a contribuírem para a morte, porém não relacionados à doença, ou estado patológico, que a produziu). ${ }^{11}$

Classificaçăo Internacional de Doenças
As categorias da variável "causa de morte" são habitualmente definidas com base na Classificação Internacional de Doenças ${ }^{12} \mathrm{e}$, dependendo das necessidades do investigador, podem admitir diferentes níveis de detalhamento:

- capítulos - são grupos genéricos (I-Doenças Infecciosas e Parasitárias; II-Neoplasmas; VII-Doenças do Aparelho Circulatório; XI-Complicações da Gravidez, Parto e Puerpério; XVII-Lesões e envenenamentos).

- categorias - são identificadas por um código de três algarismos, e constituem a base fundamental da classificação (Tuberculose Pulmonar 011; Tuberculose dos ossos e articulações 015; Peste 020; Hipertensão Essencial 401; Doença Renal Hipertensiva 403; Arritmias cardíacas 427; Fratura da clavícula 810; Intoxicação por agentes psicotrópicos 969;

\footnotetext{
10 A utilização de dados do registro civil deve considerar sua qualidade: cobertura do sistema (sub-registrol, informação incompleta ou incorreta, etc.

${ }^{11}$ Maiores informações a respeito do preenchimento do atestado de óbito podem ser obtidas na publicação "O atestado de óbito", de Ruy LAURENTI e M. Helena de Mello JORGE, editada pelo Centro Bra. sileiro de Classificação de Doenças, convênio entre a Organização Panamericana de Saúde, o Ministé rio da Saúde e a Faculdade de Saúde Pública da Universidade de São Paulo.

12 Os côdigos apresentados são os da Nona Revisão. Recentemente começou a ser utilizada a Décima Revisão, com códigos alfa-numéricos.
} 
Efeito tóxico do Chumbo e seus componentes 984; Efeito tóxico de substâncias nocivas ingeridas como alimentos 988).

- subcategorias - proporcionam informação mais detalhada, através da introdução de um quarto dígito (Tuberculose da coluna vertebral 015.0; Hipertensão essencial especificada como benigna 401.1; Taquicardia paroxística ventricular 427.1; Intoxicação por tranqüilizantes fenotiazídicos 969.1; Intoxicação por peixes e mariscos 988.0).

- agrupamento - consiste na reunião de categorias próximas (Tuberculose 010-018; Zoonoses causadas por bactérias 020-027; Doença Hipertensiva 401-405: Outras formas de doença do coração 420-429; Fratura do membro superior 810-819; Intoxicação por drogas, medicamentos e substâncias biológicas 960-979; Efeitos tóxicos de substâncias de origem não predominantemente medicinal 980-989).

Assim como na análise das características das pessoas que morrem, o estudo da mortalidade segundo a causa se faz através da construção de coeficientes e de proporções.

Coeficiente específico de mortalidade, pela causa C, em uma determinada população, em um certo período:

total de óbitos devidos a $\mathrm{C}$ ocorridos

$\mathrm{CM}_{\mathrm{C}}=\frac{\text { na população e no período }}{\begin{array}{c}\text { população sob risco de morrer } \\ \text { devido a } \mathrm{C} \text { durante o período }\end{array}} \times 10^{\mathrm{n}}$

Mortalidade proporcional, pela causa (ou grupo de causas) C, em uma população, em um certo período:

$$
\mathrm{MP}_{\mathrm{C}}=\frac{\begin{array}{c}
\text { óbitos devidos à causa } \mathrm{C} \text { ocorridos } \\
\text { na população e no período }
\end{array}}{\begin{array}{c}
\text { total de óbitos (todas as causas) } \\
\text { ocorridos na população e no período }
\end{array}} \times 100
$$

Na maioria dos coeficientes de mortalidade específicos por causa, a "população sob risco de morrer" (o denominador) é a população total; em alguns casos, no entanto, será necessário considerar certas especificidades. Por exemplo: o coeficiente de mortalidade materna corresponde ao "total de óbitos por causas ligadas à gestação, parto ou puerpério" coeficiente de mortalidade materna 
prevalência

incidência

(numerador) ponderado pelo "total de nascidos vivos" (denominador); o coeficiente de mortalidade por câncer de ovário deve excluir a população masculina do denominador.

\section{Morbidade}

Assim como a mortalidade, a morbidade está sempre referida a uma população e a um período de tempo determinados. Por outro lado, enquanto o óbito marca uma mudança radical e irreversível, o adoecimento é transitório, e admite uma gama de gradações (a doença leve, equivalente a uma perturbação pequena, tem um significado bastante distinto da doença grave, que pode levar à morte). Deste modo, embora seja possível construir indicadores genéricos de morbidade (traduzindo "doença" por internação, consulta médica, consumo de medicamentos, interrupção das atividades cotidianas por motivo de saúde, etc.), os indicadores de morbidade freqüentemente se referem a uma doença específica, ou a um grupo de doenças específico.

\subsection{A freqüência da doença}

A quantidade de casos existentes de uma doença, em uma determinada população, em um certo momento, é a prevalência da doença. Teoricamente, o momento corresponde a um "ponto" no tempo (prevalência instantânea). Em circunstâncias operacionais, é possível estabelecer o momento tomando-se diferentes unidades de tempo (semana, mês, ano); a prevalência sugere "volume".

O acompanhamento da ocorrência de uma doença, e do desfecho dos casos ocorridos, permite determinar a prevalência "pontual" da mesma, ao fim de períodos determinados (semanas, meses). Para isso, ao total de casos existentes no início do período, são somados os casos novos, e subtraídos os que se encerraram (cura, óbito, migração, etc) durante o período.

Nos estudos que visam determinar a prevalência de uma doença em uma população específica, o coeficiente de prevalência corresponderá à quantidade de pessoas afetadas pela doença no momento da investigação (ou da coleta de dados), em relação à população total.

Uma segunda medida da freqüência de uma doença é dada pela incidência, que corresponde à quantidade de casos novos, ocorridos em uma determinada população durante um certo período; a incidência sugere "velocidade" ou "intensidade". O número absoluto de casos novos de uma doença, ocorridos durante um certo período, em uma população sob risco de adquirir a doença, é o coeficiente de incidência da doença na população, no período considerado. 
Coeficiente de prevalência da doença $\mathrm{D}$ em uma população específica em um certo momento:

$$
\mathrm{CP}_{\mathrm{D}}=\frac{\begin{array}{c}
\text { total de casos da doença } \mathrm{D} \text { existentes } \\
\text { na população no momento }
\end{array}}{\text { população total no momento considerado }} \times 10^{\mathrm{n}}
$$

Os coeficientes de incidência referidos a grupos limitados e específicos (pessoas presentes a uma festa, ou que consumiram determinado produto em um determinado momento) e a períodos curtos (horas, dias ou semanas), geralmente utilizados na investigação de surtos epidêmicos localizados, são conhecidos como coeficientes de ataque. ${ }^{13}$

Coeficiente de incidência da doença D em uma população específica em um certo período:

$$
\mathrm{CI}_{\mathrm{D}}=\frac{\begin{array}{c}
\text { ne de casos novos da doença } \\
\mathrm{D} \text { na população e no período }
\end{array}}{\begin{array}{c}
\text { população exposta ao risco de contrair } \\
\text { a doença } \mathrm{D} \text { durante o período }
\end{array}} \times 10^{\mathrm{n}}
$$

Tomado como uma relação entre a quantidade de eventos ocorridos (casos novos) e o universo de eventos possíveis (a população sob risco) o coeficiente de incidência pode ser interpretado como medida geral e simplificada de risco (de probabilidade).

A interpretação e o uso das medidas de prevalência e de incidência pedem que se leve em conta a duração média da doença, definida como período médio entre o diagnóstico e o desfecho do processo (cura, morte, etc). A prevalência varia proporcionalmente ao produto da incidência pela duração média da doença; ${ }^{14}$ enfermidades de curta duração (agudas) tendem a apresentar baixa prevalência, mesmo quando a incidência é alta, e enfermidades de longa duração (crônicas) podem apresentar alta prevalência, mesmo quando a incidência é baixa.

\footnotetext{
13 O termo "taxa de ataque" costuma ser utilizado com o mesmo significado.

$14 \mathrm{P}-\mathrm{I} \times \Delta \mathrm{t}$.
} 
patogenicidade

virulência

\subsection{A gravidade da doença}

A gravidade de uma doença é função da magnitude dos eventos indesejáveis que ela provoca. A maneira mais simples de lhe medir a gravidade é através da proporção de doentes em que o processo mórbido evolui de modo insatisfatório (excessivamente prolongado, ou com complicações), ou deixa conseqüências indesejáveis (seqüela, incapacidade ou óbito) ao final do processo, em relação ao total de doentes observados.

A letalidade - proporção de óbitos em relação ao total de doentes - é uma característica própria de cada doença. Algumas doenças apresentam alta letalidade (raiva, tétano, infarto cardíaco, certos tipos de câncer, intoxicação botulínica, agranulocitose conseqüente ao uso de dipirona), e outras, letalidade praticamente nula. Um segundo fator de forte influência sobre a letalidade é a qualidade da atenção prestada aos doentes; assim, uma letalidade particularmente alta e localizada sugere atenção de má qualidade. Observe-se que, de modo geral, os indicadores da gravidade das doenças (a proporção de eventos indesejáveis) podem ser, ao mesmo tempo, indicadores da qualidade da atenção oferecida pelos serviços de saúde.

Taxa de letalidade $=$ total de óbitos devidos a D $\mathrm{x} 100$ da doença D total de doentes com D

Alguns indicadores (tradicionalmente utilizados em doenças infecciosas) dizem respeito a características do agente etiológico. A patogenicidade é a capacidade do agente de provocar a doença no hospedeiro infectado, e é dada pela proporção de doentes em relação ao total de infectados. A virulência é a capacidade do agente de provocar casos graves (proporção de casos graves em relação ao total de doentes); a virulência do agente tem influência sobre a letalidade da doença.

\section{A qualidade da medida}

$\mathrm{O}$ ato de medir ${ }^{15}$, fornece os critérios para classificar as unidades de análise segundo as categorias das variáveis, e está sempre sujeito a erros:

\footnotetext{
15 O verbo "medir" deve ser entendido em sentido ampliado, significando, também, classificar, orde. nar, etc.
} 
- erro aleatório - é a expressão da variabilidade (dispersão) inerente a qualquer série de medições; tende a se distribuir de modo simétrico, em torno de um valor central (médio) que, em certos casos, é tomado como o valor "verdadeiro" da medida.

- erro sistemático (viés) - é a expressão de uma tendenciosidade introduzida pelo procedimento de medida, pelo instrumento, ou pelo sujeito que mede; provoca um desvio (deslocamento) do valor observado em relação ao valor "verdadeiro" da medida.

A avaliação da qualidade dos instrumentos de "medida" (uma balança, um esfignomanômetro, um teste laboratorial, as perguntas de um questionário, um critério padronizado de classificação ou de diagnóstico, ... envolve dois componentes:

- validade - corresponde ao grau em que um instrumento é capaz de medir o "verdadeiro valor" de um fenômeno.

- confiabilidade - corresponde ao grau de repetibilidade da medida, isto é, de concordância dos resultados obtidos em diferentes medições do mesmo objeto.

\section{Validade}

A validade comporta uma questão conceitual freqüentemente negligenciada; o processo de redução de conceitos abstratos, para abordálos como variáveis, através de indicadores e medidas, envolve problemas que não podem ser desprezados no momento de se fazerem inferências.

A validade operacional (pragmática) de um instrumento (ou procedimento) de medida pode ser avaliada, sistematicamente, através da comparação do seu desempenho em discriminar "positivos" e "negativos", em relação à condição considerada "verdadeira", definida através da medida fornecida por um instrumento padrão, de alto poder discriminante, conhecido como padrão ouro (Quadro 3).

Quadro 3 Identificaçāo de doentes, segundo um teste e um padrão

\begin{tabular}{lccc}
\hline Teste & Doentes* & Não doentes* & Total \\
Positivo & A & B & A + B \\
Negativo & C & D & C + D \\
Total & A + C & B + D & A + B + C+D \\
\hline
\end{tabular}

$A=$ verdadeiros positivos $B=$ falsos positivos $C=$ falsos negativos $D=$ verdadeiros negativos

"segundo o Padrão Ouro 


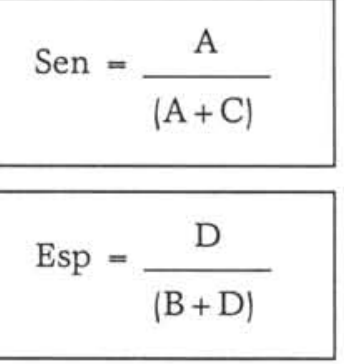

Sensibilidade: é a capacidade de um instrumento de identificar os verdadeiros positivos. É dada pelo quociente entre o número de unidades de análise identificadas como "positivas", pelo teste, e o total de "doentes verdadeiros", identificados pelo padrão.

Especificidade: É a capacidade de um instrumento de distinguir os verdadeiros negativos. É dada pelo quociente entre o número de unidades de análise identificadas como "negativas", pelo teste, e o total de "verdadeiros não-doentes", identificados pelo padrão.

A validade, qualidade inerente ao instrumento (procedimento) de medida, é dada tanto pela sensibilidade quanto pela especificidade. Um instrumento terá validade perfeita se identificar como "positivos" todos os verdadeiramente positivos ( $100 \%$ sensível), e não incluir entre os selecionados como "positivos" nenhum dos verdadeiros negativos $(100 \%$ específico).

Sensibilidade e especificidade não são independentes. Se o critério que permite caracterizar uma unidade de análise como "positiva" é muito amplo, a sensibilidade tende a ser alta, mas a especificidade tende a ser baixa. Ao contrário, quando empregamos critérios mais rígidos para reconhecer um caso como positivo (doente), aumentamos a especificidade, mas tendemos a comprometer a sensibilidade (Figura 3).

A validade exigida de um teste depende dos propósitos de seu emprego. Em certos casos é necessário garantir maior sensibilidade, mesmo em detrimento da especificidade (identificação de infectados por HIV entre doadores, em um serviço de hemoterapia). Em outros, é mais importante dar primazia à especificidade, em detrimento da sensibilidade (identificar os casos com dor precordial que devem ser submetidos à cirurgia cardíaca).

Nas medidas em escalas contínuas (glicose sangüínea em mg\%) o critério de classificação freqüentemente é definido através de um "ponto de corte", que distingue os "positivos" (valores superiores) e os "negativos" (valores inferiores). Neste caso, haverá um valor da escala, o "ponto de corte ideal" (suponhamos x mg\%), que fornece, ao mesmo tempo, maiores sensibilidade e especificidade. Deslocando-se o ponto de corte num ou noutro sentido da escala, será possível definir o "balanço" entre sensibilidade e especificidade que melhor convier aos propósitos do estudo.

A sensibilidade e a especificidade indicam a proporção de identificações corretas em relação a um padrão, são inerentes ao instrumento (procedimento) de medida e não sofrem influência da prevalência, uma vez que a redução de $(\mathrm{A}+\mathrm{C})$ implica a redução proporcional de $\mathrm{A}$ e de $\mathrm{C}$.

O número absoluto de unidades de análise classificadas, erroneamente, em um conjunto de medições, por outro lado, depende da fre- 
Figura 3 Validade de diferentes critérios de diagnóstico

\section{Critério amplo}

Qualquer caso de dor precordial será considerado infarto do miocárdio.

Qualquer paralisia flácida de inicio súbito será considerada poliomielite.

\section{Critério restrito}

0 diagnóstico de infarto do miocárdio depende de evidência anatomopatológica.

Apenas os casos com sorologia positiva serāo considerados poliomielite.
Alta sensibilidade: poucos casos "verdadeiros" deixarāo de ser classificados como "doentes".

Baixa especificidade: serāo incluidos muitos casos "falsos" (que não apresentam a doença em questão) entre os selecionados como "doentes".
Baixa sensibilidade: muitos casos "verdadeiros" podem deixar de ser classificados como tal.

Alta especificidade: serão incluidos poucos casos "falsos" (que nāo apresentam a doença em questão) entre os selecionados como "doentes".

qüência relativa (prevalência) do evento que está sendo medido. E pode ser estimado através do valor preditivo do teste (instrumento ou procedimento).

Valor preditivo positivo é a proporção de verdadeiros positivos entre os identificados como positivos pelo teste.

Valor preditivo negativo é a proporção de verdadeiros negativos entre os identificados como negativos pelo teste.

Se a prevalência do evento (total de casos $=\mathrm{A}+\mathrm{C}$ ) é baixa, o $\mathrm{VP}+$ tende para zero ${ }^{16}$ e, em um conjunto de medidas, a quantidade de falsos positivos tende a ser alta, mesmo se a especificidade do teste for alta. Se, ao contrário, a prevalência do evento é alta, o VP-tende para zero ${ }^{17} \mathrm{e}$, em um conjunto de medidas, a quantidade de falsos negativos tende a ser alta, mesmo se a sensibilidade do teste for alta.

$$
\mathrm{VP}+=\frac{\mathrm{A}}{(\mathrm{A}+\mathrm{B})}
$$

$$
V P-=\frac{D}{(C+D)}
$$

$16 \mathrm{O}$ numerador $(A)$ é pequeno e o denominador $(A+B)$ é semelhante a $B$, que é grande.

$17 \mathrm{O}$ numerador $(\mathrm{D})$ é pequeno e o denominador $(\mathrm{C}+\mathrm{D})$ é semelhante a $\mathrm{C}$, que é grande. 
Quando o interesse se volta para uma medida particular (o objeto é um indivíduo) a prevalência eqüivale à probabilidade a priori (anterior ao teste) do sujeito ser positivo verdadeiro (possuir a característica que define o evento). E o valor preditivo eqüivale à probabilidade, a posteriori (após o teste), de o resultado (positivo ou negativo) do teste corresponder à verdadeira condição do sujeito (doente ou sadio).

\section{Confiabilidade}

A confiabilidade é dada pela capacidade de um instrumento não variar seus resultados quando a medição do mesmo objeto se repetir. A testagem da confiabilidade de um instrumento qualquer baseia-se na comparação dos resultados obtidos em diferentes medições.

- a confiabilidade re-teste diz respeito à estabilidade do instrumento, no tempo, e envolve um problema conceitual, pois pressupõe a imutabilidade do objeto medido.

- a confiabilidade de aplicação diz respeito à estabilidade do instrumento, quando utilizado por diferentes operadores. Quanto mais estruturado (em termos de aplicação) um instrumento, maior sua confiabilidade de aplicação.

A maneira mais simples de estimar a confiabilidade de um instrumento é calcular a taxa global de concordância entre os resultados obtidos nas diversas medições (proporção de resultados coincidentes em relação ao total de observações).

A medida da concordância do conjunto dos resultados obtidos em uma série de medidas é função das características da variável envolvida. Se o instrumento gera variáveis contínuas, se pode utilizar o coeficiente de correlação de Pearson, baseado em modelos de regressão linear. ${ }^{18} \mathrm{Se}$ o instrumento gera uma variável nominal, será preciso corrigir a medida para compensar a distribuição aleatória de eventos (a concordância casual entre resultados); neste caso emprega-se o Índice Kappa.

\section{Distribuição de freqüência}

1 Tábua de freqüência

O primeiro passo da apuração dos dados consiste em construir uma tábua de freqüência, a partir da matriz de dados. A freqüência ab-

18 Ver item sobre correlação linear. 
soluta corresponde ao número de unidades de análise pertencentes a cada categoria de uma variável. A freqüência relativa (geralmente expressa em porcentagem) corresponde à proporção da freqüência de cada categoria em relação ao total de observações (Quadro 4).

Quadro 4 Tábua de freqüência

$\begin{array}{lcc}\text { Categorias } & \text { Freqüência absoluta } & \text { Freqüência relativa } \\ \text { A } & \mathrm{fa} & \mathrm{fa} / \mathrm{N} \\ \mathrm{B} & \mathrm{fb} & \mathrm{fb} / \mathrm{N} \\ \mathrm{C} & \mathrm{fc} & \mathrm{fc} / \mathrm{N} \\ \mathrm{Z} & \mathrm{fz} & \mathrm{fz} / \mathrm{N} \\ \text { Total } & \mathrm{N} & 100 \%\end{array}$

A tábua de freqüência é uma maneira de organizar os dados para facilitar a análise; é o investigador quem escolhe livremente o modo de construí-la. A apresentação dos dados, na forma de tabelas e gráficos, no entanto, deve atender a certas convenções.

\section{Representação tabular}

As tabelas têm quatro elementos essenciais: o título precede a tabela e deve indicar o dado descrito (o quê?), as categorias da(s) variável (eis) que o descrevem (como?), e as condições em que o dado foi obtido (quando? e onde?). O corpo é constituído pelo conjunto de linhas e colunas, e o cruzamento de uma linha com uma coluna corresponde a uma célula, ou casela. O cabeçalho é a parte da tabela que descreve o conteúdo de cada coluna. A coluna indicadora descreve as categorias que a variável admite. Os elementos complementares incluem a indicação da fonte dos dados (sempre incluida) e, quando necessário, as notas de esclarecimento, ambas no rodapé da tabela.

A construção de tabelas deve observar as seguintes convenções:

- as tabelas devem ser fechadas no alto e em baixo por linhas horizontais; o cabeçalho é separado do corpo por uma linha horizontal.

- é possível separar a coluna indicadora do corpo por um traço vertical, mas não devem existir traços verticais limitando a tabela ou o corpo.

- os totais e subtotais devem ser destacados. 
- nenhuma casela da tabela deve ficar em branco; quando o valor da casela for nulo, se deve preenchê-la com hífen (-); quando não se dispõe do dado, se devem utilizar reticências (...).

- a uniformidade de casas decimais deve ser mantida.

\section{Representação gráfica}

A construção de gráficos é um recurso que permite a visualização de dados quantitativos, num formato sintético. O procedimento básico consiste em representar as quantidades, os valores da distribuição, através de áreas que lhe correspondam proporcionalmente, de modo que a área total, sob o gráfico, corresponda a $100 \%$ da distribuição. Todo gráfico deve apresentar título e escala; no caso de variáveis qualitativas, a escala dos valores da variável corresponde à relação das categorias.

A representação gráfica deve levar em conta a natureza da variável. A distribuição de freqüência de variáveis qualitativas (nominal ou ordinal) e de variáveis quantitativas discretas deve ser apresentada em gráficos de barra, ou de setores circulares. A distribuição de freqüências de classes de variáveis contínuas deve ser apresentada através de histograma, ou de polígono de freqüência.

Gráfico de barras (Figura 4) - Sobre um eixo (horizontal) são construídos retângulos de base uniforme e altura proporcional à freqüência (indicada no eixo vertical) das categorias que cada um representa. Os nomes das categorias devem ser indicados sob cada retângulo. As barras devem estar separadas umas das outras, refletindo, assim, a natureza qualitativa da variável.

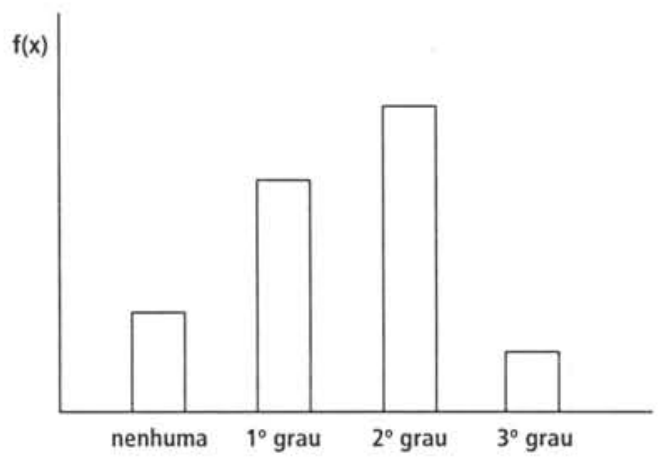


Gráfico de setores circulares (Figura 5) - Divide-se a área total de um círculo em subáreas (setores) proporcionais às freqüências das categorias que representam; freqüentemente é necessário incluir legendas indicativas das categorias.

Figura 5 Gráfico de setores: internaçōes no hospital "A", no ano de 1998, segundo grupos de causas

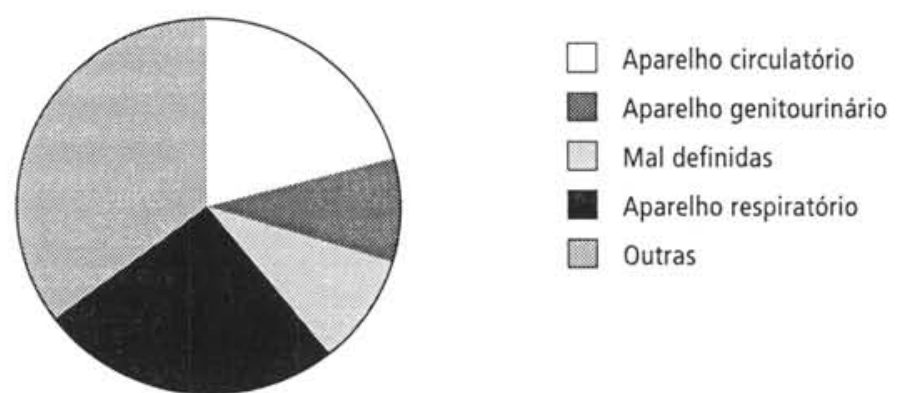

O histograma e o polígono de freqüências são construídos em um sistema de coordenadas cartesianas, no qual a escala dos valores das classes da variável é representada na abscissa, e a escala de freqüências, na ordenada.

O histograma (Figura 6) é constituído por barras justapostas, uma evidência da natureza contínua da variável. Se os intervalos de classe têm amplitudes diferentes, a base de cada retângulo deve ser proporcional à amplitude do intervalo; a altura corresponderá à "densidade de classe", dada pelo quociente entre a freqüência relativa e a amplitude do intervalo. Observe-se que tal procedimento implica que a área total dos retângulos seja equivalente à freqüência total da distribuição.

O polígono de freqüências (Figura 6) é um gráfico linear, obtido pela ligação dos pontos definidos pelo valor médio do intervalo de cada classe (abscissa) e pela freqüência da classe correspondente (ordenada). O polígono é fechado, no eixo das abscissas, nos pontos médios das classes hipotéticas imediatamente anterior à primeira, e posterior à última. A área delimitada pelo polígono e pelo eixo das abscissas será equivalente ao total da distribuição.

A variação da freqüência de um evento no tempo pode ser apresentada através de um diagrama linear (Figura 7), construído sobre um sistema de coordenadas cartesianas; a abscissa corresponde à escala de tempo e a ordenada à freqüência do evento. gráfico de setores circulares

histograma

poligono de freqüências

diagrama linear 
Figura 6 Histograma e poligono de frequêencias: estatura dos alunos da za série da escola "A"

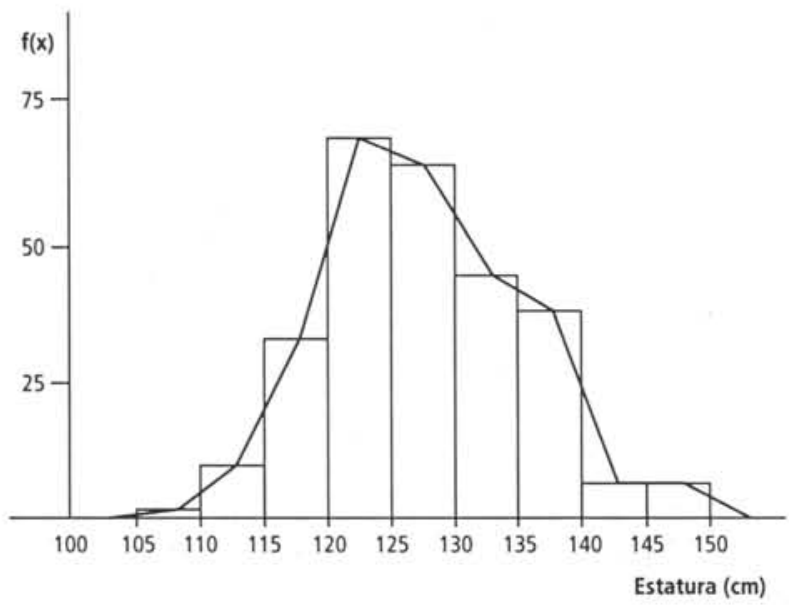

Figura 7 Diagrama linear: número de casos da doença "A", ocorridos na cidade "C", no ano de 1998

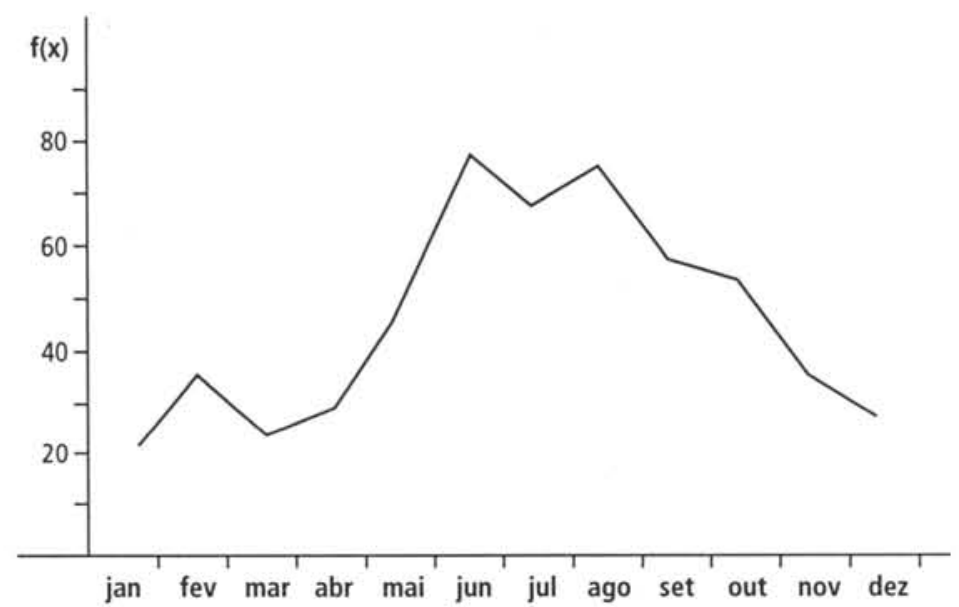

\section{$4 \quad$ Medidas de tendência central}

O modo mais simples, e resumido, de falar algo sobre a distribuição de freqüência de uma variável quantitativa é através de valores centrais, em torno do qual os dados se distribuem; o "centro" sintetiza, em um único valor, toda a distribuição. 
A média, convencionalmente representada, em estatística, pelo sinal $\bar{x}$, ou pela letra grega $\mu$, é dada pelo quociente entre o somatório de todos os valores observados $\left(\mathrm{x}_{\mathrm{i}} \cdot \mathrm{f}_{\mathrm{i}}\right)$ e o total de observações $\left(\sum \mathrm{f}_{\mathrm{i}}=\mathrm{N}\right)$.

A média é o valor que todas as observações $\left(\mathrm{x}_{\mathrm{i}}\right)$ teriam se não houvesse variação; não fornece nenhuma informação sobre os desvios $\left(x_{i}-\mu\right)$, isto é, sobre o quanto os valores observados estão afastados do valor médio; os valores aberrantes (muito afastados da média) tendem a exercer forte influência sobre a média da distribuição.

Se os dados estão agrupados em classes, os $\mathrm{x}_{\mathrm{i}}$ assumirão os valores do ponto médio da classe correspondente (a diferença entre os valores observados e o ponto médio da classe é desprezada). Se a primeira, e/ou a última classe for "aberta", a média não poderá ser calculada.

A mediana é o valor que divide a distribuição ao meio; o número de observações com valores maiores do que o da mediana é igual ao número de observações com valores menores do que a mesma. Nos casos em que valores aberrantes influenciam a média, ou existem classes abertas (impossibilitando o cálculo da média), a mediana é de grande utilidade; quando há muitos valores repetidos, a interpretação da mediana sofre prejuízo.

O primeiro passo para se obter o valor da mediana é dispor os valores observados em ordem crescente (ou decrescente). Se o número de observações (N) é ímpar, a mediana corresponde ao valor que ocupa a posição central da distribuição ordenada; se o número de observações é par, a mediana corresponderá à média aritmética entre os valores que ocupam os dois postos centrais. Se a variável é contínua, e os dados estão agrupados em classes, após identificar-se a classe mediana determina-se o valor da mediana por regra de três (em função do número de unidades de análise que a classe mediana contém, e da magnitude do seu intervalo).

Além da mediana, outras medidas dividem o conjunto ordenado de valores da variável em partes de proporções conhecidas. Os quartis são valores que dividem o conjunto ordenado de valores da variável em quatro partes iguais: $1 / 4$ dos valores da distribuição são menores do que o primeiro quartil $\left(Q_{1}\right)$, o segundo quartil $\left(Q_{2}\right)$ corresponde à mediana, e $3 / 4$ dos valores são menores do que o terceiro quartil $\left(Q_{3}\right)$. O cálculo dos valores dos quartis é análogo ao da mediana. Os valores que dividem o conjunto ordenado de valores da variável em cem partes iguais são percentis.

A moda corresponde ao valor mais freqüente, ela nem sempre existe, e nem sempre é única. A moda pode ser usada como medida de tendência central da distribuição de uma variável qualitativa, e é fortemente afetada pela maneira como as categorias (ou as classes de categorias contínuas) são constituídas. média

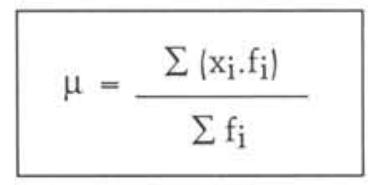

mediana

quartis

moda 
desvio

limites

variância

desvio padrão
Medidas de dispersão

As medidas de dispersão fornecem informação sobre a variabilidade dos valores da distribuição em torno das medidas centrais. A diferença entre cada valor observado $\left(\mathrm{x}_{\mathrm{i}}\right)$ e a média da distribuição é o desvio $\left(\mathrm{x}_{\mathrm{i}}-\mu\right)$. A informação mais simples sobre a dispersão de uma distribuição é dada pela amplitude de variação, pela diferença entre seus limites, que são os desvios mínimo e máximo.

A média da distribuição da variável altura dos alunos das turmas $\mathrm{A}$ e B pode ser, suponhamos, 1,75 metros. A informação de que na turma A o aluno mais alto mede 1,95 e o mais baixo 1,55 metros, enquanto na turma B o mais alto mede 1,80 e o mais baixo 1,65 metros, melhora a descrição da distribuição. Sabemos que, embora as médias sejam iguais, na turma A a altura dos alunos admite maior variação (amplitude de variação de 0,40 metros), e a distribuição é mais dispersa, enquanto na turma B a altura dos alunos é mais homogênea, os limites de variação são menores (amplitude de variação de 0,15 metros), e a distribuição tem menor dispersão.

Limites e amplitude de variação são medidas incompletas, pois baseiam-se apenas nos dois desvios extremos, não fornecem informação sobre a distribuição entre esses extremos. Para obter uma descrição mais completa sobre a dispersão de uma distribuição, será necessário construir uma medida de dispersão que resuma, em um único valor, o conjunto de todos os desvios observados.

$\mathrm{Na}$ impossibilidade de se utilizar a média de todos os desvios, pois, pela própria natureza da média o somatório de todos os desvios é sempre nulo (os desvios negativos e positivos se anulam), recorre-se a um artificio: utilizar o quadrado dos desvios (necessariamente um número positivo). A variância $\left(\sigma^{2}\right)$ é dada pela razão entre o somatório do quadrado dos desvios e o total de observações. ${ }^{19} \mathrm{~A}$ raiz quadrada positiva da variância é o desvio padrão $(\sigma)$, medida que sintetiza a informação sobre a dispersão da distribuição na ordem de grandeza original.

$$
\sigma^{2}=\frac{\sum\left(\mathrm{x}_{\mathrm{i}}-\mu\right)^{2} \cdot \mathrm{f}_{\mathrm{i}}}{\mathrm{n}} \quad \sigma=+\sqrt{\frac{\sum\left(\mathrm{x}_{\mathrm{i}}-\mu\right)^{2} \cdot \mathrm{f}_{\mathrm{i}}}{}}
$$

\footnotetext{
${ }^{19} \mathrm{Em}$ uma amostra é necessária uma correçāo, que consiste em substituir n por (n-1).
} 


\subsection{Principios gerais de amostragem}

Freqüentemente tomamos decisões com base em informações parciais sobre aquilo que nos interessa: experimentamos uma uva antes de comprar o cacho; decidimos assistir um filme depois de ver o trailer; investigamos a concentração sangüínea de uma substância examinando alguns mililitros; provamos de uma pequena porção da comida, para decidir sobre o tempero, etc.

Em termos estatísticos, uma parte (subconjunto não-vazio) de uma população constitui uma amostra. A menor parte distinta e identificada da população, para fins de enumeração e sorteio da amostra, é a unidade amostral; o conjunto de todas as unidades amostrais é o universo amostral.

Além de proporcionar economia de tempo e de recursos, a definição de amostras permite estudar as populações infinitas ou as muito grandes, viabiliza as pesquisas em que o processo de investigação provoca a destruição do objeto de estudo (testes de resistência de materiais) ou envolve risco para os participantes (testes de novas substâncias e procedimentos terapêuticos), etc. A estimativa de parâmetros (medidas estatísticas) populacionais, com base em dados amostrais, requer uma metodologia que permita determinar o grau de validade ${ }^{20}$ dos achados.

As técnicas de inferência estatística se sustentam no pressuposto da aleatoriedade da amostra, ou seja, em estar a definição de uma determinada amostra associada a uma probabilidade. Uma amostra é probabilística quando cada unidade amostral tem uma probabilidade conhecida, e diferente de zero, de pertencer à amostra; e supõe sempre algum tipo de sorteio aleatório (de tipo lotérico). Amostras não-probabilísticas comprometem a análise estatística, e impossibilitam que se avalie o grau de precisão e confiança das estimativas dos parâmetros populacionais.

O tamanho da amostra é função dos seguintes fatores:

1) Variabilidade dos elementos que constituem a população, no que diz respeito à variável estudada; quanto mais heterogênea a população, maior deve ser a amostra.

2) Freqüência (prevalência) do atributo na população estudada; quanto mais raro o atributo, maior deve ser a amostra.

20 Trata-se da validade das conclusões de um estudo como um todo, e não da sensibilidade e especificidade de um procedimento de medida específico (ver o item Validade, na página 151). amostra probabilistica 
3) Precisão desejada, isto é, da magnitude do erro que pode ser tolerado; quanto maior a precisão, maior deve ser a amostra.

4) Grau de confiança desejado, isto é da probabilidade de a estimativa de um parâmetro corresponder ao valor real do parâmetro na população estudada; quanto maior o grau de confiança, maior deve ser a amostra.

Existem diversos processos de seleção de amostras probabilísticas. A escolha do mais adequado depende dos objetivos do estudo, das condições em que o mesmo será realizado, das características da população estudada e da possibilidade de atender aos requisitos que as técnicas impõem.

- amostragem casual simples - a amostra é definida através de uma seqüência de sorteios sem reposição (uma amostra de tamanho n exige n sorteios). Assim, no início do processo, cada unidade amostral tem a mesma probabilidade de pertencer à amostra; esse tipo de amostragem requer uma listagem de todas as unidades amostrais.

- amostragem casual estratificada - usa-se nos casos em que a população é composta por subpopulações (extratos) cujas unidades amostrais são mais homogêneas em relação a uma característica (idade, sexo, inserção social), o que influencia o parâmetro a ser medido; assim, o sorteio deve ser feito, independentemente, em cada extrato, de forma a se respeitar a estratificação. Em certas situações, é importante os extratos estarem representados na amostra na mesma proporção em que aparecem na população total (amostragem com partilha proporcional).

- amostragem sistemática - aproveita uma ordenação natural do universo amostral (fichas em um fichário, casas de uma rua, ruas transversais a uma avenida), desde que os critérios de ordenação não influenciem as variáveis estudadas; e dispensa a listagem das unidades amostrais. A razão entre o tamanho do universo e o da amostra estabelece um intervalo amostral com $\mathrm{k}$ unidades. Um único sorteio entre as primeiras $\mathrm{k}$ unidades do universo amostral ordenado é suficiente para definir toda a amostra (a ser composta pelas unidades amostrais: i, selecionada pelo sorteio, $i+k, i+2 k, i+3 k, i+4 k$, etc).

- amostragem por conglomerados - um conglomerado equivale a um subconjunto da população no qual estão preservadas as características "de grupo" da população total. Enquanto os extratos se caracterizam pela homogeneidade (interna) de seus elementos, que os torna heterogêneos entre si (externamente), os conglomerados caracterizam-se pela heterogeneidade (interna) de seus elementos, e pela homogeneidade (externa) dos elementos entre si. O procedimento amostral consiste em sortear sucessivas amostras em conglomerados de diferentes estágios. Em havendo a heterogeneidade interna requerida aos conglomerados, a 
amostra dos moradores de um bairro pode ser definida através do sorteio de uma amostra das ruas do bairro, seguido de sorteios de uma amostra de prédios dessas ruas, de apartamentos desses prédios e, finalmente, da amostra de moradores desses apartamentos. Observe-se que a unidade amostral varia de um estágio para o outro.

Em algumas situações, na dependência dos objetivos da investigação, será necessário selecionar amostras de conveniência (não-probabilísticas). As atividades de Vigilância e de monitoramento, cujo objetivo não é estimar parâmetros populacionais, mas sim identificar condições que representem risco para a saúde, freqüentemente utilizam amostras de conveniência (para monitorar o grau de potabilidade da água de um manancial as amostras devem ser colhidas em locais sabidamente críti$\cos )$.

\subsection{Estimativa de parâmetros e intervalo de confiança}

De uma população de tamanho $\mathrm{N}$, em que a média dos valores assumidos por uma variável contínua $\mathrm{X}$ vale $\mu$, extraiu-se uma amostra de tamanho n. A média $\bar{x}$, calculada a partir dessa amostra, é uma estimativa do parâmetro $\mu .{ }^{21} \mathrm{O}$ erro padrão da média e o intervalo de confiança são indicadores da precisão da estimativa $\bar{x}$ de $\mu$.

A amostra selecionada, o conjunto específico das $n$ unidades de análise, é uma das inúmeras amostras de igual tamanho que poderiam ter sido sorteadas. Diferentes amostras fornecem diferentes valores para a estimativa $\bar{x}$ da média $\mu$ da população. O conjunto de valores de $\bar{x}$, dado por todas as amostras possíveis ${ }^{22}$, de tamanho $n$, tem distribuição normal em torno da média $\mu$ da população. ${ }^{23}$

Teorema do limite central: "se, de uma população com média $\mu$ e desvio padrão $\sigma$, ambos finitos, forem tomadas todas as amostras casuais de tamanho n possíveis, e em cada uma delas se determinar a média $\bar{x}$, então a distribuição de $\bar{x}$ se aproximará da normal com média $\mu$ e desvio padrão $\sigma / \sqrt{n}$, à medida que n for grande." amostras

de conveniência

erro padrão da média

e intervalo de confiança

\footnotetext{
21 A notação estatística emprega letras gregas para referir-se aos parâmetros, medidos na população inteira, e letras do nosso alfabeto para as estimativas amostrais dos parâmetros populacionais.

22 A quantidade de amostras pode ser calculada por análise combinatória.

23 Para amostras com $\mathrm{n}<120$, os valores de $\bar{x}$ têm distribuição $\mathrm{t}$.
} 


$$
S_{X}=\frac{S}{V_{n}}
$$

curva normal
O desvio padrão da distribuição de $\bar{x}$ corresponde ao erro padrão da média $\left(\mathrm{S}_{\mathrm{X}}\right)$ e pode ser estimado a partir do desvio padrão $(\mathrm{S})$, obtido através dos dados amostrais, e do tamanho da amostra (n).

Um alto erro padrão da média pode significar ser grande a variabilidade da população (em relação à característica medida pela variável

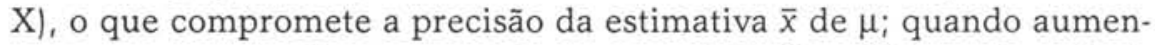
tamos o tamanho da amostra (n), o erro padrão da média tende a diminuir, e a precisão de $\bar{x}$, como estimador de $\mu$, a aumentar.

Média e desvio padrão são os parâmetros que definem a distribuição normal. A curva normal (Figura 8) é simétrica em torno da média e assemelha-se a um sino cujo formato varia em função da dispersão dos valores, isto é, da variância. Na distribuição normal, os valores da média, da mediana e da moda coincidem.

Olhando a Figura 8, é possível verificar ser a freqüência dos valores de $\mathrm{X}(\mathrm{f}(\mathrm{x}))$ sempre alta para valores próximos à média, e cair à medida que o desvio $(x-\mu)$ cresce. A área sob a curva normal, definida pelo intervalo entre os pontos $(\mu+\sigma)$ e $(\mu-\sigma)$, contém aproximadamente $68 \%$ do total de observações; entre os pontos $(\mu+1,96 \sigma)$ e $(\mu-1,96 \sigma)$ se situam $95 \%$ das observações e entre os pontos $(\mu+2,58 \sigma)$ e $(\mu-2,58 \sigma)$, cerca de $99 \%$. Embora a curva seja assintótica ${ }^{24}$ em relação ao eixo das abscissas, admite-se, para fins práticos, que o intervalo entre os pontos $(\mu+3 \sigma)$ e $(\mu-3 \sigma)$ contenha $100 \%$ das observações (amplitude máxima de $6 \sigma$ ) (Figura 9).

Figura 8 Normais com mesma média e diferentes variâncias

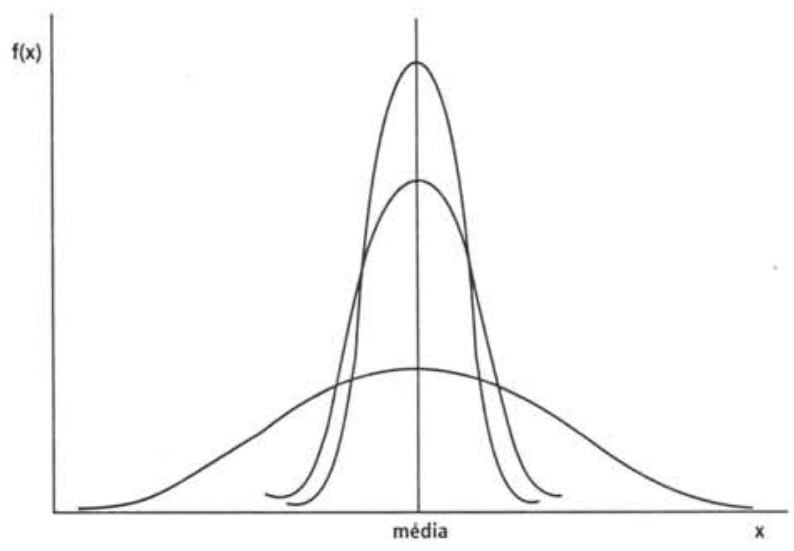

24 Os extremos da curva nunca tocam o eixo dos valores de $\mathrm{x}$; os limites teóricos são $-\infty$ e $+\infty$. 


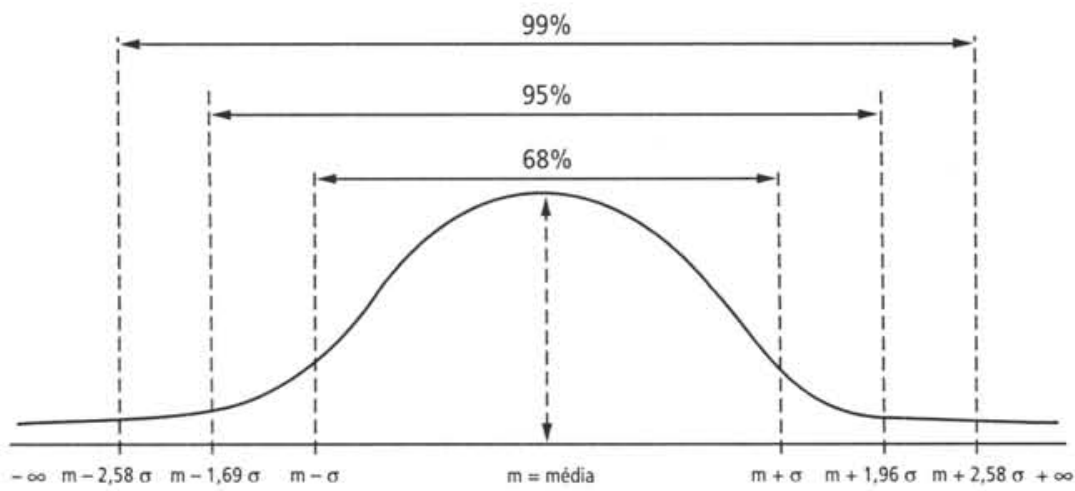

-Modificado de BERQUÓ e cols. - Bioestatistica, São Paulo, Ed. Pedagógica e Universitária Ltda., 1981

Uma certa área sob a curva pode ser considerada uma medida da probabilidade de, em uma única observação, ser obtido um determinado valor de x. ${ }^{25}$ Assim, em uma distribuição normal, com média $\mu$ e desvio padrão $\sigma$, a probabilidade de se obter um valor de $\bar{x}$ maior do que a média $(\mu)$ é de $50 \%$ (já vimos que a média e a mediana têm o mesmo valor); a probabilidade de se obter um valor de $\bar{x}$ maior do que $(\mu+\sigma)$ é de $16 \%^{26}$; a probabilidade de se obter um valor de $\bar{x}$ maior do que $(\mu-1,96 \sigma)$, e menor do que $(\mu+1,96 \sigma)$, é de cerca de $95 \%$; a probabilidade de se obter um valor de $\bar{x}$ menor do que $(\mu-2,58 \sigma)$, ou maior do que $(\mu+2,58 \sigma)$, é de cerca de $1 \%$.

A confiança associada a um determinado valor da média $(\bar{x})$, fornecido por uma amostra específica, entre as inúmeras possíveis (aquela efetivamente sorteada), está relacionada à probabilidade de esse valor corresponder ao valor real do parâmetro $\mu$ da população.

Considerando-se que o conjunto de valores de $\bar{x}$ fornecidos por todas as amostras de tamanho $\mathrm{n}$ tem distribuição normal, podemos construir um intervalo de confiança na escala de valores de $\bar{x}$, de modo que, em uma proporção conhecida do total das amostras possíveis, de tamanho $\mathrm{n}$, o valor de $\mu$ esteja contido nesse intervalo. A proporção do total

\footnotetext{
25 A probabilidade associada a diferentes valores de $\mathrm{x}$ depende da quantidade de desvios padrão com que estes valores se afastam da média.

$26 \mathrm{O}$ intervalo de um desvio, para cada lado da média, representa $68 \%$ da área total; a parte equivalente aos valores maiores do que um desvio corresponde à metade (o lado direito da curva) dos $32 \%$ complementares.
} 
de amostras que o intervalo contém equivale a uma probabilidade, e é o nível de confiança $(1-\alpha)$.

A amplitude do intervalo de confiança é função da magnitude do desvio padrão da distribuição de $\bar{x}$, que corresponde ao erro padrão da média $(\mathrm{s} / \sqrt{ } \mathrm{n})$, e do nível de confiança desejado; desse nível de confiança depende a quantidade $(z)$ de desvios padrão que define os limites do intervalo.

Intervalo de confiança para o parâmetro $\mu$ ao nível de confiança $(1-\alpha): P(x-z . s / \sqrt{ } n<\mu<x+z . s / \sqrt{ } n)=1-\alpha$

Estabelecer um nível de confiança de $95 \%(1-\alpha=0,95)$, por exemplo, significa definir a quantidade $\mathrm{z}$ (neste caso $\mathrm{z}=1,96$ ) de desvios padrão $(\mathrm{s} / \sqrt{ } \mathrm{n}$ ) que delimita, na distribuição de $\mathrm{x}$, um intervalo (uma área da curva) que abriga $95 \%$ de todas as observações (amostras de tamanho n) possíveis; a área restante, representada por $\alpha$, contém o restante $(5 \%)$ das observações.

Se, em um nível de significância seguro (em geral $>90 \%$ ), a amplitude do intervalo de confiança é alta, $\bar{x}$ não é um bom estimador de $\mu$. Por exemplo: a altura média $(\bar{x})$ de uma população, calculada com base em uma certa amostra, de tamanho n, é de 1,70 metros, sendo que em $90 \%$ (o nível de confiança) de todas as amostras possíveis, de mesmo tamanho, o valor da média estará entre 1,44 e 2,08 metros (o intervalo de confiança).

Se, em um nível de significância alto, a amplitude do intervalo de confiança é baixa, $\bar{x}$ é um bom estimador de $\mu$. Por exemplo: a altura média $(\bar{x})$ de uma população, calculada com base em uma certa amostra, de tamanho n, é de 1,70 metros, sendo que em $95 \%$ (o nível de confiança) de todas as amostras possíveis de mesmo tamanho, o valor da média estará entre 1,64 e 1,80 metros (o intervalo de confiança).

Quando a variabilidade da população em relação à característica medida pela variável $\mathrm{X}$, é grande, o erro padrão da média $(\mathrm{s} / \sqrt{ } \mathrm{n})$ tende a ser alto e o intervalo de confiança tende a ter grande amplitude. Neste caso, para aumentar a confiança do estimador $\bar{x}$ de $\mu$, será necessário aumentar o tamanho da amostra (n).

\section{Lugar, pessoa e tempo}

Para conhecer a distribuição das doenças nas populações humanas é necessário considerar três questões básicas: 1) Onde a doença se manifesta? 2) Quem adoece? 3) Quando a doença ocorre? 
A observação do fato de que determinadas doenças ocorrem, preferentemente, em determinados lugares é bastante antiga. Um dos escritos atribuídos a Hipócrates, do século V antes de Cristo, se intitulava Dos ares, das águas e dos lugares. Em meados do século XIX se considerava o ambiente "corrompido por miasmas morbíficos" a origem das doenças. Viam-se as epidemias, atribuídas às condições de pobreza, insalubridade e amontoamento, nos bairros populares, como evidência de uma espécie de "patologia social". Com o desenvolvimento da teoria microbiana, o espaço de ocorrência da doença tendeu a se tornar uma questão ecológica, de caráter natural e biológico, a envolver a geologia, a topografia, o clima, a flora, a fauna, etc.

A teoria dos focos naturais das doenças infecciosas, desenvolvida na década de 1930, como explicação da ocorrência de zoonoses nas fronteiras agrícolas, atribui ao espaço a condição de "paisagem natural", na qual circula um agente etiológico (patobiocenose). Ao modificar este ambiente natural, o homem provoca alterações ecológicas que interferem na circulação do agente etiológico.

A geografia médica, disciplina que data do século passado, estuda a "importância do 'meio geográfico' no aparecimento e distribuição de uma determinada doença". ${ }^{27}$ Neste caso, o "meio geográfico" inclui tanto os elementos da "paisagem", agora paisagem modificada pelo homem, quanto os "fatores humanos ou sociais". A geografia médica descreve a distribuição espacial da doença segundo uma grande diversidade de variáveis: clima, relevo, solo, hidrografia, flora, fauna, presença de agentes etiológicos, de vetores ou de reservatórios, características das habitações, condições de saneamento, distribuição e densidade da população, hábitos socioculturais, atividade econômica, etc.

Ainda que leve em conta elementos da "geografia humana", isto é, da sociologia, o conceito tradicional de espaço se tem mostrado insuficiente para dar conta da dinâmica ambiental envolvida no aparecimento da doença. Se os diversos elementos que compõem o ambiente são vistos como conjunto de "fatores" isolados, apesar de relacionados, perde-se a historicidade do processo que determina o modo como o homem ocupa e transforma o espaço. Devemos entender o "ambiente", portanto, numa visão mais totalizante, como um espaço físico e social organizado pela ação do homem, segundo as necessidades econômicas.

27 LACAZ, C. da S. Introdução à Geografia Médica do Brasil, São Paulo, Ed. Universidade de São Paulo, 1972. 
E o homem, ao organizar o espaço, estabelece um sistema de relações (dos homens entre si e dos homens com a "natureza"), característico, em constante transformação; assim, as condições necessárias ao aparecimento das doenças alteram-se com o tempo.

\subsection{Espaço e doença no Brasil contemporâneo}

O período seguinte à segunda guerra mundial se caracterizou por uma intensa expansão econômica, apoiada no avanço tecnológico. Os Estados Nacionais assumiram a condução do desenvolvimento econômico e social, segundo a perspectiva de integração crescente da economia no mundo capitalista ocidental.

No Brasil, foram desenvolvidos grandes projetos de infra-estrutura (energética, de transportes e de comunicação), de expansão e modernização do parque industrial e da atividade agrícola. E o extraordinário crescimento econômico se fez acompanhar da exploração predatória dos recursos naturais e de intensa mobilização das populações.

A transferência de um grande número de pessoas de seus lugares de origem para áreas de fronteira agrícola e de atividade extrativista, resultou no aumento da incidência de malária e de outras doenças endêmicas (leishmaniose), além da degradação e da contaminação do ambiente (queimadas, mercúrio). Por outro lado, a modernização da atividade agropecuária estimulou a migração para centros urbanos, acelerando o processo de urbanização e incentivando a demanda de bens e serviços (educação, saúde, moradia, saneamento).

A distribuição desigual dos benefícios do crescimento acentuou a concentração da riqueza, aumentou o contingente de excluídos e exacerbou as desigualdades sociais e regionais. No espaço das cidades médias e grandes, cresceram as favelas e os conjuntos habitacionais destinados às classes de baixa renda, e se configurou uma situação de segregação social, que favorece a violência e a drogadição. A aglomeração e a precariedade das condições de saneamento, por sua vez, facilitam a transmissão de diversos agentes infecciosos, como os da meningite, da cólera, do dengue.

\section{As pessoas}

As pessoas diferem umas das outras por uma grande quantidade de atributos. Uma variável de pessoa é um atributo que permite classificar as pessoas segundo grupos distintos (categorias).

As variáveis de pessoa expressam diferenças pessoais de diversas ordens: biológica (grupo sangüíneo, estado imunológico), social (ocupa- 
ção, renda, escolaridade, estado civil), cultural (hábitos alimentares ou de consumo, costumes). Observe-se, no entanto, que os diferentes atributos pessoais dizem respeito a um mesmo sujeito, correspondem a diferentes perspectivas de abordagem do mesmo objeto, e não devem ser tomados como fatores independentes uns dos outros.

Idade e sexo são variáveis de pessoa que aparecem em qualquer texto de Epidemiologia. Embora não haja dúvida em relação à definição das mesmas, e se verifiquem diferenças importantes da mortalidade e da morbidade, segundo a idade e o sexo, não é possível separar componentes dessas diferenças, a um só tempo biológicas e sociais.

Em outros casos (classe social) a dificuldade está em encontrar um substituto (um indicador) adequado para expressar um conceito "mal estruturado", cuja definição é pouco evidente e sobre a qual não há consenso.

\section{A distribuição da doença no tempo}

O principal instrumento para o estudo da variação temporal da ocorrência da doença é o diagrama linear (ver Figura 7). Nesse diagrama, construído sobre um sistema de coordenadas cartesianas, a abcissa corresponde a uma escala de tempo cronológico (datado segundo o calendário) e a ordenada ao número de casos ocorridos em cada período (dias, semanas, meses ou anos), em uma determinada população, de um determinado local. Através do diagrama, procura-se registrar a ocorrência histórica da doença a fim de determinar:

- a tendência secular: o comportamento da incidência em períodos longos.

- a variação cíclica: a regularidade da variação dos valores máximo e mínimo da incidência, segundo intervalos de tempo recorrentes.

- a variação sazonal: as variações cíclicas, segundo épocas ou períodos específicos (estações ou meses do ano, dias da semana, horas do dia).

- o nível endêmico: a incidência "habitual" ou endêmica e a ocorrência de epidemia, incidência excessivamente alta em relação aos padrões "habituais".

A tendência secular diz respeito às modificações sistemáticas da incidência ao longo de anos, independente do caráter cíclico ou sazonal que a distribuição possa ter. Seu estudo requer dados sobre a incidência em um intervalo suficientemente grande de tempo. Atualmente, observam-se tendências de: crescimento da incidência das doenças ditas crônico-degenerativas (cardiovasculares, neoplasias, diabetes, etc); persistência das doenças infecciosas nos países em desenvolvimento; decréscimo da incidência de doenças infecciosas nos países desenvolvidos, e

tendência secular 
variação cíclica

sazonalidade

diagrama de controle

faixa endêmica de crescimento da incidência/prevalência de alguns agravos específicos (AIDS, acidentes, violência).

A variação cíclica é característica de doenças infecciosas em que o período entre os picos de incidência corresponde ao tempo necessário para que se acumulem susceptíveis na população (novos nascimentos).

A sazonalidade geralmente indica que algum fator ambiental participa, com peso relevante, no complexo de interações do período pré-patogênico. Os meses quentes favorecem a ocorrência de doenças diarreicas, enquanto as doenças respiratórias agudas são mais freqüentes nos meses frios. A sazonalidade de uma doença pode decorrer da variação da densidade de vetores nas diferentes épocas do ano.

Os conceitos de endemia e epidemia sempre implicam a referência a uma população determinada, em uma área determinada. O termo surto é freqüentemente empregado para designar os aumentos não-habituais da incidência a ocorrerem em um período relativamente curto, num espaço restrito e bem localizado. Pandemia refere-se a um aumento não-habitual da incidência que se estende por uma área ampla, nãocircunscrita, e atinge diversos países, em diferentes continentes.

Em termos operacionais, a determinação da incidência "habitual" (ou "esperada") de uma doença tem como referência a incidência média mensal (ou semanal) em uma série de anos. ${ }^{28} \mathrm{O}$ monitoramento constante da incidência, através de um diagrama de controle (Figura 10), permite estabelecer limites endêmicos, definidos por um intervalo de $\pm \mathrm{z}$ desvios padrão em torno da incidência histórica média de cada mês. ${ }^{29}$

Os limites máximo e mínimo do diagrama de controle estabelecem uma faixa endêmica, na qual a incidência é considerada "normal" ou "habitual". Incidências superiores ao limite máximo esperado configuram situações epidêmicas. O limite endêmico inferior pode ser útil na avaliação do impacto das ações de controle.

A quantidade $\mathrm{z}$ de desvios padrão utilizada para definir os limites endêmicos, estabelece a tolerância quanto à amplitude de variação da incidência (em torno da média histórica de cada mês) a ser considerada "normal". Quanto maior a quantidade de desvios, menor será a sensibilidade do diagrama para detectar situações epidêmicas.

No diagrama da Figura 10, construído com dados imaginários, o limite máximo esperado está definido por um desvio padrão acima da incidência média de cada mês $(z=1)$. Neste caso, a probabilidade de que

\footnotetext{
28 No caso de doenças inexistentes em determinado local, a ocorrência de um único caso pode ser considerado um fenômeno epidêmico.

${ }^{29} \mathrm{~A}$ incidência média de cada mês permite considerar as possíveis variações sazonais.
} 


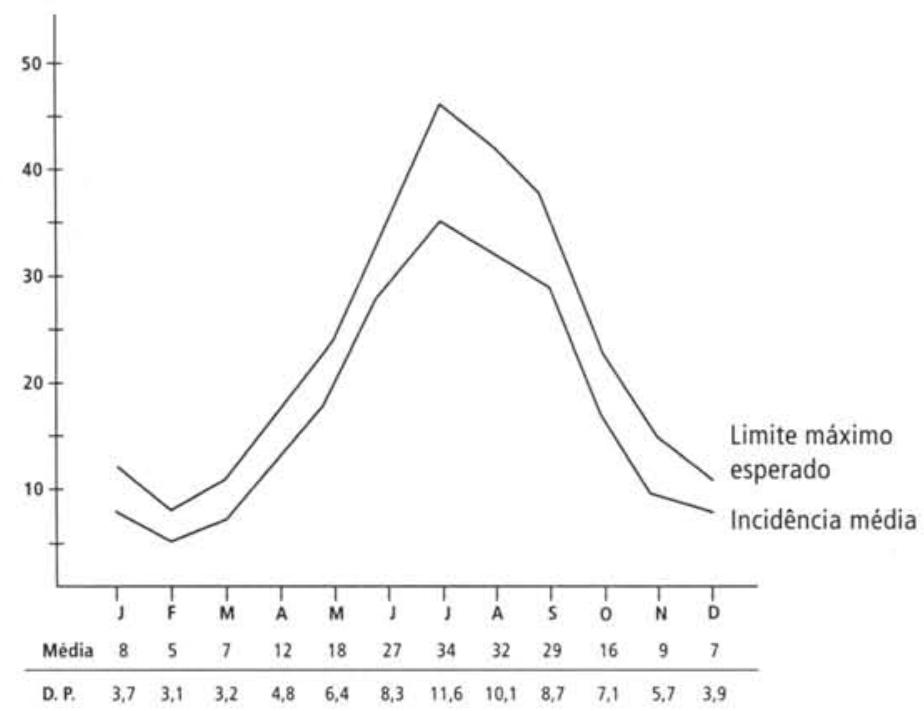

uma incidência superior ao limite máximo esperado se deva a uma "casualidade" é de $16 \%$; isto é, há $84 \%$ de chance de estar ocorrendo uma alteração do quadro epidemiológico que favorece a ocorrência da doença. Quando z vale dois, a probabilidade de uma incidência "anormal" (maior do que o limite) dever-se a uma casualidade é de $2,5 \%$ e a probabilidade de tratar-se de uma alteração das condições epidemiológicas é de cerca de $97,5 \%$

O diagrama de controle é apenas um critério estatístico para identificar incidências pouco prováveis, em condições "habituais". A caracterização de uma situação de surto, ou de epidemia, deve levar em consideração diversos outros critérios, como a evolução da incidência no epidemia tempo, as características das pessoas acometidas, o espaço de ocorrência, a existência de relação entre os casos, etc.

O aumento "não-habitual" da incidência de uma doença pode decorrer de: ${ }^{30}$

- introdução repentina de um agente em uma população com grande proporção de indivíduos susceptíveis.

\footnotetext{
30 Problemas relacionados à qualidade dos serviços de saúde, ou de produtos de uso médico - como a concentração de mortes de recém-nascidos em berçários ou a ocorrência de gestações indesejadas conseqüentes ao uso de anovulatórios falsificados - podem ser considerados de caráter epidêmico.
} 
- contato acidental de grupos específicos de pessoas com agentes tóxicos ou infecciosos (intoxicação alimentar, acidente industrial localizado).

- modificações no complexo de fatores e condições envolvidos no processo de pré-patogênese de doenças presentes, de forma endêmica, em uma determinada região, que favoreçam o "estímulo à doença".

Uma epidemia é um processo limitado a um intervalo de tempo, e admite três fases ou momentos genéricos. A progressão, período de aumento crescente da incidência, o período de incidência máxima, de duração variada; e a regressão, período de queda da incidência, com tendência à estabilização em uma nova faixa endêmica (que pode estar próxima da incidência original, acima ou abaixo da mesma).

A regressão é conseqüência da evolução do quadro epidemiológico que provocou o aumento da incidência:

- da diminuição progressiva do número de susceptíveis.

- do esgotamento dos que foram expostos a riscos acidentais.

- da superação das condições que favorecem o "estímulo à doença", seja através das ações de Vigilância e controle, seja em conseqüência de processos naturais. ${ }^{31}$

As diferenças na duração das fases têm servido como critério para a caracterização de tipos de epidemia:

- epidemia explosiva (maciça, instantânea) - ocorre em conseqüência de uma exposição, acidental e transitória, de um grupo restrito de pessoas a um agente específico de um agravo, agente cujo período de incubação é curto. Assim, a grande maioria dos casos ocorre em um intervalo igualmente curto, e se atinge a incidência máxima rapidamente. Como a exposição é transitória, os expostos logo se esgotam, de modo que o período de regressão também costuma ser curto; os surtos de intoxicação alimentar são casos típicos desta categoria.

- epidemia progressiva (lenta, propagada) - ocorre em conseqüência da propagação de pessoa a pessoa (em cadeia). Tanto a fase de progressão quanto a de regressão são prolongadas. As epidemias de doenças que se transmitem de pessoa a pessoa, independente da via de transmissão (respiratória, oral, sexual ou por vetores), como o sarampo, a meningite, o dengue, etc. são exemplos clássicos dessa categoria. ${ }^{32}$

\footnotetext{
31 A persistência das ações de vigilância e controle pode reduzir a incidência a níveis significativa. mente inferiores aos da faixa endêmica original.

$32 \mathrm{~A}$ introdução de agentes novos em populaçōes altamente susceptiveis acarretará uma epidemia de tipo explosivo, mesmo que a transmissão se faça de pessoa a pessoa.
} 
- epidemia por fonte comum - ocorre em conseqüência da propagação de um agente desde a contaminação de uma fonte comum (água, ar ou alimentos). Como a progressão costuma ser relativamente rápida, e as durações das fases de incidência máxima e de regressão dependem da persistência, ou não, da contaminação, a epidemia pode comportarse tanto de modo explosivo quanto persistente.

Os tipos de epidemias correspondem a modelos teóricos, genéricos. Algumas doenças podem ser transmitidas tanto de uma fonte comum quanto através do contato com doentes (cólera, febre tifóide). Freqüentemente, dada a complexidade da interação dos elementos que originam a epidemia e lhe determina a evolução no tempo, observamse configurações mistas. Observe-se que alguns contaminantes ambientais (por exemplo, metais pesados) necessitam longos períodos até seus efeitos se manifestarem; nestes casos, o aumento "não-habitual" da incidência pode ser lento, apesar da contaminação de uma fonte comum.

\section{Vigilância Epidemiológica}

As primeiras ações para o controle das doenças e epidemias, como a quarentena e o isolamento, são práticas muito antigas. A partir da segunda metade do século XIX, com o desenvolvimento da microbiologia, e de investigações de campo voltadas para a identificação dos elos da cadeia de transmissão das doenças infecciosas, surgiu a idéia de vigilância, no sentido da observação sistemática dos contatos de doentes.

Com as campanhas de erradicação de diversas doenças infecciosas, iniciadas após a segunda grande guerra, a vigilância deixou de se fazer sobre as pessoas (doentes e contatos) e passou a ter como objeto a doença. Consolidou-se, assim, a idéia de Vigilância Epidemiológica como observação ativa e sistemática da distribuição da ocorrência de agravos, a avaliação da situação epidemiológica com base na análise das informações obtidas, e a definição (e a difusão ampla) das medidas de prevenção e controle pertinentes. Em alguns casos, a execução e a avaliação das medidas de controle se incluem entre as atribuições da Vigilância Epidemiológica.

O conjunto de atividades de Vigilância Epidemiológica configura um sistema, em geral voltado para agravos específicos, cujo objetivo final é a prevenção, e constitui um instrumento indispensável à elaboração, ao acompanhamento e à avaliação de programas de saúde. O sistema de vigilância deve assegurar um fluxo contínuo, regular e suficientemente ágil de informação completa e precisa entre seus vários níveis. 
Entre os objetivos específicos da Vigilância Epidemiológica estão:

- monitorar as tendências da morbidade e da mortalidade.

- determinar os níveis endêmicos, detectar surtos epidêmicos e identificar os fatores envolvidos na ocorrência dos mesmos.

- identificar os grupos populacionais mais vulneráveis.

- elaborar informes e normas técnicas que possam orientar as ações de controle.

- avaliar o impacto e a adequação das medidas de prevenção e controle.

- identificar novos problemas de Saúde Pública e os elementos envolvidos no seu aparecimento.

- fornecer subsídios para o planejamento.

A estrutura dos sistemas de Vigilância Epidemiológica pode variar em função de características particulares do agravo, do quadro epidemiológico, dos objetivos específicos da vigilância e da estrutura do sistema de saúde. Genericamente, os sistemas comportam diferentes níveis, com competências e atribuições bem definidas. Aos níveis periféricos (local) competem a coleta, a consolidação e o envio dos dados ao nível superior (regional ou central), além da execução das ações de controle. Ao nível central cabe consolidar e analisar os dados recebidos dos níveis inferiores (regional e local); realizar investigações e estudos especiais; definir normas técnicas, elaborar e divulgar periodicamente informes e recomendações e supervisionar as atividades de vigilância nos níveis inferiores, apoiando técnica e operacionalmente a execução das ações.

Os princípios de municipalização e descentralização, preconizados pelo SUS, estão transformando profundamente o papel das instâncias de nível municipal e local do sistema. De mero executor de tarefas preconizadas em programas verticalizados, de mero gerador e repassador de dados brutos ao nível superior, o município tende a assumir a posição de agente relativamente autônomo; agente que precisa compreender as situações, eleger e programar as ações adequadas, e executá-las com qualidade suficiente para que se traduzam em resultados positivos. O nível central de âmbito municipal adquire, portanto, importância estratégica no processo de implementação do SUS.

O estabelecimento de um sistema de Vigilância Epidemiológica requer a definição precisa:

- do que será considerado um "caso" do agravo em questão.

- das informações a serem coletadas a respeito de cada caso.

- das fontes regulares de informação.

- do fluxo e da periodicidade da informação coletada.

- das competências e atribuições de cada instância (local, regional ou central) do sistema. 
- da definição das normas técnicas que orientam as ações de controle.

- da periodicidade da divulgação de relatórios, normas e recomendações.

O conjunto de informações de interesse para a Vigilância Epidemiológica inclui dados sobre a estrutura demográfica da população (idade, sexo, inserção social), sobre o ambiente (condições de saneamento, exposição a substâncias e situações de risco), sobre os agravos (data e local de ocorrência, características clínicas, gravidade) e sobre as características dos casos (idade, sexo, estado imunitário e nutricional, inserção social).

As informações sobre a estrutura demográfica, em geral, são oferecidas pelos estudos e levantamentos oficiais (censo). Dados sobre o ambiente podem ser obtidos em serviços públicos especializados (órgãos relacionados ao controle do meio ambiente, companhias de abastecimento de água, órgãos da área do trabalho). ${ }^{33}$ As informações sobre os agravos e sobre as características dos casos podem ser obtidas de diferentes fontes de dados, através de diferentes mecanismos.

A vigilância rotineira baseia-se na informação, fornecida por médicos e outros profissionais de saúde, dos casos de "doenças de notificação obrigatória"; é de natureza passiva, depende da participação espontânea dos profissionais e, portanto, está sujeita a sub-registro. Em geral, as unidades básicas de saúde centralizam as informações sobre os casos ocorridos em sua área de atuação, para repassá-las, periodicamente, aos níveis superiores.

É possível utilizar, de modo complementar, informações colhidas junto a laboratórios de apoio diagnóstico; quando é importante identificar a espécie, ou a cepa, do agente etiológico (meningite, malária), a participação do laboratório torna-se imprescindível.

Os registros hospitalares constituem importante fonte de informação, principalmente se o objeto da vigilância é uma doença grave, cujo tratamento requer internação. Esses registros são especialmente importantes na vigilância de eventos adversos relacionados a procedimentos de diagnóstico ou terapêuticos (infecção hospitalar, efeitos colaterais da radioterapia).

Serviços especializados, onde são mais freqüentes as internações por determinadas doenças, podem servir como sentinelas, informando, prontamente, aos órgãos responsáveis da ocorrência de casos de agravos que demandam investigação epidemiológica imediata.

33 Tanto os dados populacionais quanto as informações sobre o ambiente podem ser obtidas, diretamente, através de estudos de prevalência (ver o item Estudos de Prevalência, na página 179). vigilância rotineira

sentinelas 
vigilância ativa

agravos inusitados

evento sentinela
Dependendo das necessidades e da existência de recursos, é possível estabelecer um sistema de vigilância ativa, através de visitas regulares aos laboratórios e hospitais, para coleta direta da informação. O simples levantamento periódico dos diagnósticos, nos registros dos hospitais e dos laboratórios, é útil para estimar-se a subnotificação de casos.

Os registros de óbito são fontes de dados fundamentais para a vigilância de agravos com alta letalidade. Mesmo no caso de agravos menos letais, os sistemas de vigilância baseados nos óbitos (e não nos casos) têm importância, pois fornecem uma estimativa do sub-registro de casos' (quando a letalidade é conhecida), e permitem a identificação de "excessos" localizados de óbitos em determinadas áreas, ou em determinados grupos populacionais; esses "excessos" são sugestivos de um aumento real da letalidade, conseqüente à maior patogenicidade do agente, ou a problemas na qualidade da assistência.

Os serviços de saúde devem estar preparados para detectar agravos inusitados. A ocorrência localizada de casos com quadro clínico semelhante, cujo diagnóstico não é claro, pode indicar a introdução de um agente, até então inexistente, em uma determinada área, a ocorrência de formas não usuais de uma doença conhecida, ou mesmo o surgimento de doenças novas (de etiologia desconhecida).

Freqüentemente, a informação sobre casos ou surtos de um agravo conhecido, ou sobre a ocorrência de um aglomerado de agravos inusitados, aparece na imprensa, ou é motivo de boatos. Os sistemas de vigilância devem levar em conta esse tipo de fonte, investigar a pertinência da informação, determinar a extensão real do problema e tomar as medidas de controle necessárias.

A análise dos dados obtidos nas várias fontes envolve, basicamente, a construção de gráficos e tabelas, e o cálculo de indicadores. O acompanhamento da incidência do agravo no tempo, através do diagrama de controle, permite detectar tendências de crescimento e a ocorrência de surtos. A comparação de indicadores de diferentes grupos populacionais (sexo, idade, ocupação, inserção social) permite identificar os grupos mais vulneráveis.

A detecção de uma situação não-habitual deve ser rápida o suficiente para que as medidas de controle tenham eficácia. No caso de doenças graves, de caráter agudo (meningite), e nos estágios finais dos programas de erradicação de uma doença transmissível, quando a incidência é reduzida e a circulação do agente é limitada, um pequeno aglomerado de casos, ou mesmo a ocorrência de um único caso, exige providências imediatas.

Um evento sentinela é um acontecimento indicativo de uma situação que requer uma intervenção imediata. A ocorrência de um caso au- 
tóctone de uma doença transmissível, até então inexistente num determinado lugar, impõe medidas para evitar que a mesma se propague, e se torne endêmica. A concentração inusitada de casos (ou óbitos) do mesmo agravo, ou o aumento na freqüência da ocorrência de agravos raros (malformações congênitas), exigem uma investigação para esclarecer os fatores responsáveis e orientar as medidas necessárias à prevenção.

A investigação epidemiológica é uma atividade fundamental da vigilância. Seu objetivo final é interromper a progressão do agravo na população, através da descoberta de casos não-informados, da observação dos contatos, do tratamento precoce e do isolamento (quando indicado) de todos os casos, da proteção (imunização) dos susceptíveis, e das identificação e eliminação dos fatores envolvidos na origem e na propagação do agravo.

A investigação epidemiológica de surtos, ou de casos, implica a visita ao local de ocorrência do caso, para confirmação do mesmo, coleta de dados, através de formulários próprios e execução das medidas de controle. A natureza dos dados a serem coletados varia com as características do agravo. Os dados devem ser suficientes para se alcançar o objetivo de interromper a progressão do agravo. De modo geral, são necessárias informações sobre características individuais dos casos (sexo, idade, etc.), possíveis fontes de infecção (locais freqüentados, alimentos consumidos, produtos utilizados), data de início dos sintomas, características clinicas do caso, susceptibilidade dos contatos, condições ambientais, além da coleta de material (do doente ou do ambiente) para análise laboratorial.

A identificação da origem do agravo, a eleição das medidas adequadas e a produção de normas e informes, envolve conhecimento a respeito: do período de incubação da doença, da presença e distribuição de outros casos, dos modos de transmissão ou de propagação, das características dos indivíduos dos grupos mais atingidos, das condições ambientais, da época de ocorrência (sazonalidade), da intensidade da circulação de pessoas e mercadorias, etc.

As doenças, ou estados de saúde, de fácil diagnóstico e razoavelmente freqüentes, cujo desfecho pode ser modificado por ações de cuidados à saúde e que, em conjunto, refletem a gama de pacientes e problemas de saúde encontrados na prática médica, são considerados condições traçadoras. A extensão em que o cuidado a estes agravos coincide com o padrão de cuidado preestabelecido permite avaliar a qualidade do cuidado oferecido.

Tradicionalmente, as ações preventivas, de caráter coletivo, implicam, por um lado, o monitoramento da ocorrência de agravos e o con-

\section{investigação} epidemiológica condiçōes traçadoras 
trole da propagação dos mesmos - papel reservado à Vigilância Epidemiológica - e por outro, o controle, anterior à ocorrência de qualquer agravo, de fatores que direta ou indiretamente podem constituir risco à saúde individual ou coletiva; esse controle é função da Vigilância Sanitária. No entanto, a complexidade a envolver o aparecimento da doença, na coletividade, exige que se encare a prevenção de forma integral, e se busque articular os vários espaços de atuação das ações preventivas:

- o monitoramento da ocorrência de agravos /Vigilância Epidemiológica)

- o controle da qualidade dos bens e dos serviços consumidos (Vigilância Sanitária)

- o monitoramento dos riscos ambientais (Vigilância Ambiental)

- a investigação científica e tecnológica, em apoio à definição de normas e ao desenvolvimento de novos produtos e de procedimentos terapêuticos e de diagnóstico.

A simples troca de informações pode aumentar a eficiência das intervenções nos diversos "espaços". A informação epidemiológica sobre os casos ocorridos pode orientar as ações de Vigilância Sanitária e ambiental; a informação sobre a qualidade do ambiente e dos serviços e produtos consumidos é de grande utilidade para a investigação epidemiológica.

O objetivo comum de prevenção, e a abordagem da doença como fenômeno coletivo, exigem, e propiciam, ao mesmo tempo, a articulação entre a Epidemiologia e o conjunto de ações de vigilância. As normas que orientam o controle da qualidade dos serviços e produtos, e os parâmetros de avaliação da exposição ambiental a agentes potencialmente patogênicos, encontram apoio no conhecimento científico e no desenvolvimento tecnológico, sendo a Epidemiologia um de seus principais instrumentos. Por outro lado, as informaçōes geradas pelas atividades das vigilâncias, colhidas na atividade de campo, constituem a matéria prima essencial da atividade epidemiológica de investigação dos fatores envolvidos no período de pré-patogênese e de desvendamento da história natural das doenças.

\section{Epidemiologia e experimento}

Um dos procedimentos básicos para a produção do conhecimento científico é o experimento. O experimento consiste na observação dos efeitos da ação de um fator específico sobre um objeto determinado, através da comparação do "comportamento" do objeto na ausência e na presença do fator, quando todas as demais circunstâncias a cercarem o experimento permanecem inalteradas ("controladas"). 
O fator cuja ação está sendo investigada é a variável independente, sendo o resultado dessa ação a variável dependente (depende da ação do fator). Os demais fatores capazes de interferir nos resultados, relacionados às condições em que se dá o experimento, são as variáveis intervenientes.

Dois requisitos são necessários para caracterizar um experimento: 1) o controle sobre a variável independente; o pesquisador é quem estipula a intensidade da exposição do objeto ao fator; 2) o controle sobre as variáveis intervenientes, que autoriza a afirmar (ou negar) estar o comportamento da variável dependente associado à ação da variável independente.

As possibilidades de controlar as variáveis intervenientes diferem, segundo o objeto de estudo. Os experimentos nos campos da física ou da química, realizados em laboratórios, permitem amplo controle das condições em que se realizam (pressão, temperatura, pH, etc.). Nas ciências biológicas, em geral, as dificuldades são maiores. E, embora nos experimentos em laboratório seja possível um controle bastante razoável (cobaias selecionadas geneticamente, alimentadas de modo uniforme, mantidas nas mesmas condições ambientais), haverá sempre algum nivel de variabilidade biológica.

Quando se trata do processo saúde-doença em populações humanas, a limitação das possibilidades de controlar as variáveis intervenientes é extrema, principalmente se o período entre a ação do fator e a resposta a ser observada for prolongado. Nos estudos que visam identificar fatores associados ao aparecimento de doenças, dificilmente o pesquisador tem controle sobre a variável independente, em virtude de limitações óbvias, de ordem ética, à exposição deliberada de pessoas a fatores supostamente patogênicos.

Os estudos epidemiológicos costumam ser observacionais, ou seja, procuram simular as condições experimentais através de artifícios metodológicos (os desenhos de estudo, o tratamento estatístico); esse procedimento permite reconhecer associações entre eventos (variáveis) que ocorrem independentemente da vontade (do controle) do pesquisador. A impossibilidade de controlar a variável independente (a exposição) é compensada pela criação, e aplicação, de critérios especiais na formação dos grupos de comparação. A dificuldade de controlar as variáveis intervenientes é contornada pela definição de grupos de comparação homogêneos em relação às características condicionadas por essas variáveis.

1 Estudos de prevalência (seccionais, de corte transversal)

Esse tipo de estudo mede a prevalência de um agravo, ou de um evento qualquer, em uma população bem definida, em um determinado variável independente, variável dependente

variáveis intervenientes

estudos epidemiológicos 
momento do tempo. No estudo de prevalência, tanto os dados sobre a morbidade quanto aqueles relativos às características das pessoas e dos "lugares" 34 , são colhidos simultaneamente e dizem respeito a um mesmo momento, refletem um determinado instante da história da doença na população. Como a população a que se refere o estudo fornece os denominadores dos indicadores de prevalência, a mesma deve ser rigorosamente definida.

$\mathrm{Na}$ maior parte das vezes, as limitações financeiras e operacionais que envolvem a realização de inquéritos domiciliares impõem a utilização de amostras. Apesar dos problemas relacionados à validade e a confiabilidade dos registros, e à cobertura dos serviços, além das dificuldades para a definição dos denominadores, os estudos de prevalência podem empregar dados secundários.

Estudos baseados na clientela de um serviço específico são limitados, como fonte de informação sobre a população total (amostras de conveniência tendem a introduzir viés de seleção), mas podem ter utilidade para o planejamento e a avaliação das ações.

Os instrumentos de coleta de dados (questionários auto-administrados ou entrevistas) devem ser simples e de fácil aplicação. ${ }^{35} \mathrm{~A}$ simplicidade do instrumento e o treinamento adequado dos entrevistadores tendem a aumentar a confiabilidade da informação obtida.

Os estudos de prevalência permitem identificar associações entre uma doença, ou agravo, e determinadas características (fatores) pessoais, ou de "lugar". Observe-se que um dos requisitos para se afirmar uma relação de causalidade é a seqüência no tempo: a causa deve, necessariamente, preceder o efeito! Assim, uma vez que as variáveis dependente e independente são observadas simultaneamente, em um só momento, a associação evidenciada através de um estudo seccional não implica uma relação causal.

\section{Estudos ecológicos}

Caracterizam-se pela utilização de dados agregados, referidos a uma população de uma determinada área. São relativamente pouco dispendiosos e de fácil operacionalização, pois utilizam dados secundários. Fornecem medidas de correlação entre médias populacionais, geralmente expressas sob a forma de coeficientes. As principais limitações a

\footnotetext{
$34 \mathrm{O}$ termo refere-se aos diferentes espaços que se configuram em uma região (bairro, cidade, etc.). 35 A tomada de medidas (peso, pressão arterial) ou a coleta de amostras (sangue, água de consumo domiciliar), além de aumentarem os custos, costumam prolongar demasiadamente o período de trabatho de campo.
} 
este tipo de estudo se relacionam à qualidade dos registros, à disponibilidade dos bancos de dados, e ao grau de compatibilidade entre os mesmos (nivel de agregação).

Apesar dos argumentos tradicionais a respeito da limitação dos estudos ecológicos na investigação de hipóteses causais (falácia ecológica), a aceitação crescente da idéia de que os determinantes da morbidade na população não se confundem com os fatores de risco individuais, e de que a prevenção deve estar voltada para a redução da ocorrência da doença na população, têm colaborado para uma revalorização dos mesmos. Paralelamente, a tendência à expansão da disponibilidade de bancos dados informatizados (não só na área da saúde) e o desenvolvimento de técnicas de análise espacial têm ampliado as possibilidades de aplicação desse tipo de estudo.

\section{Estudos longitudinais}

Permitem identificar fatores associados à ocorrência de uma doença ou agravo em nível individual. Diferentemente dos estudos ecológicos, que trabalham com dados agregados, as unidades de análise dos estudos longitudinais são indivíduos, as informações sobre a presença do fator e sobre a morbidade dizem respeito à mesma pessoa. A observação da ocorrência de morbidade e da presença de um fator de risco é feita em momentos distintos, o que permite medir a influência de um determinado fator sobre a probabilidade (o risco) de ocorrência de uma determinada doença ou agravo.

Os estudos de seguimento (de coortes) partem de uma população

coortes sadia (o mais homogênea possivel) na qual se distinguem um grupo (coorte) de expostos ${ }^{36}$ e outro de não-expostos, ao fator considerado. Mede-se a ocorrência da doença (incidência) em cada grupo, após um período de observação, variável em função das características (incubação) da doença em questão. A definição operativa da variável "exposição", e dos critérios para o diagnóstico da doença, ou agravo, devem permitir a distinção, clara e precisa, entre os expostos e os não-expostos, assim como entre os doentes e os não-doentes. Mede-se a associação entre exposição e doença através da comparação das incidências da doença entre os expostos e os não-expostos (medidas diretas do risco de adoecer).

Considerado o desenho ideal para a identificação dos fatores que aumentam o risco individual de adoecimento, esse tipo de estudo tem

${ }^{36}$ A exposição pode ser episódica (vazamento industrial) ou permanente (obesidade, hábito de fumar). 
limitações operacionais consideráveis. O exame periódico das coortes costuma exigir altos custos financeiros. A observação das coortes por períodos muito longos traz problemas, como excesso de perdas (migração, morte por causas não-relacionadas ao estudo) ou modificação da situação inicial de exposição (modificação de hábitos). O estudo de eventos raros exige o seguimento de coortes muito numerosas, o que pode inviabilizar esta estratégia de estudo.

Os estudos de caso-controle partem da identificação de um grupo de doentes (casos) e de um grupo de sujeitos sabidamente sadios (controles), semelhantes aos doentes em todos os demais aspectos (idade, sexo, posição social, atividade, local de moradia, etc). E avaliam os níveis de exposição ao fator de interesse, retrospectivamente (no passado). Assim como nos estudos de coortes, os critérios a caracterizarem os casos e a definição da variável "exposição" devem ser claros e precisos. Embora não forneçam medidas diretas de incidência - os denominadores populacionais não estão disponíveis - os estudos de caso-controle permitem estimar o risco de se sofrer o agravo, associado à exposição a um ou mais fatores, com boa aproximação.

Esses estudos são relativamente mais simples, mais rápidos e de menor custo do que os de coortes, e especialmente indicados para o estudo de doenças, ou agravos, raros (de baixa incidência), ou com período de incubação prolongado (que exigiriam coortes muito grandes e seguimento excessivamente prolongado). Os principais problemas desse tipo de estudo se relacionam à qualidade da informação sobre a exposição (colhida retrospectivamente) e à dificuldade para a seleção do grupo controle adequado.

\section{Estudos de intervenção (ensaios clínicos)}

São estudos experimentais nos quais a variável independente tem efeito presumidamente benéfico, positivo (um fármaco, um novo procedimento preventivo ou terapêutico). O primeiro passo desse estudo consiște na definição precisa dos casos, dos sujeitos que poderiam beneficiar-se da intervenção e estariam em condições de participar do estudo. ${ }^{37} \mathrm{O}$ conjunto dos casos é separado em dois grupos: os integrantes do grupo intervenção recebem uma substância ativa (fármaco, vacina), ,38

\footnotetext{
${ }^{37}$ As situaçōes em que a participação no estudo pode representar risco (gravidez, debilidade excessi. va, etc.) devem ser critêrios de exclusão.

38 Ou são submetidos a um novo procedimento, rotina ou atividade programática; neste caso, o place. bo pode ser substituído pelo procedimento, rotina ou atividade tradicionais.
} 
os integrantes do grupo controle recebem um placebo ${ }^{39}$, ou uma outra substância, de efeito conhecido.

O controle das variáveis intervenientes depende do grau de homogeneidade dos casos em relação às características individuais capazes de interferir nos resultados (idade, estágio e gravidade da doença, presença de outras doenças ou de complicações, grau de exposição a um agente determinado). Em existindo homogeneidade entre todos os casos, os indivíduos serão alocados nos grupos aleatoriamente, critério considerado mais adequado para assegurar a comparabilidade entre os grupos intervenção e controle, pois admite-se que, assim, as diferenças relativas à variação biológica tenderiam a se distribuir de forma equivalente nos dois grupos.

Após um período preestabelecido, os sujeitos são examinados a fim de se determinar a proporção de resultados positivos (melhora, cura, ganho de imunidade) em cada grupo. Para conferir confiabilidade às observações, é necessário ter bem estabelecidos os critérios que definem as categorias da variável dependente (cura, benefício obtido). Para evitar viés de observação, tanto os sujeitos submetidos ao experimento los casos) quanto os pesquisadores que avaliam os resultados, devem desconhecer a qual dos grupos (intervenção ou controle) cada sujeito pertence. 40

Os estudos de intervenção com seres humanos devem respeitar uma série de princípios éticos, definidos internacionalmente: a informação, aos participantes, a respeito de todos os aspectos do experimento (propósitos, metodologia, riscos potenciais); o caráter voluntário da participação, com possibilidade de abandono a qualquer momento; a suspensão do experimento, com acesso imediato de todos os participantes ao fármaco ou ao procedimento, assim que seus benefícios se tornem evidentes. Observe-se que um produto (ou procedimento) só pode ser experimentado em seres humanos depois de um grande número de testes de laboratório, tanto in vitro quanto em animais.

\section{Análise dos dados}

A análise de dados nos estudos epidemiológicos consiste, basicamente, em identificar associações entre um (ou mais) fator(es) e a ocorrência da doença, em procurar relacionar a variação da ocorrência da doença

\footnotetext{
39 Substância inerte, sem efeito farmacológico.

40 Os estudos em que se respeitam estas condições são conhecidos como duplo-cegos.
}

principios éticos 
fator de risco, fator de proteção com a presença de um determinado fator. Se, em presença do fator, a doença é mais freqüente, o fator é dito "de risco"; se, ao contrário, a doença é menos freqüente, trata-se de um fator de proteção.

Os diferentes desenhos de estudo fornecem diferentes medidas de ocorrência tanto da doença quanto do fator, o que implica em diferentes formas de medir a associação entre as mesmas (Quadro 5).

\section{Medidas de associação estatística}

As medidas de associação estatística medem a "co-incidência" de um agravo e de uma condição (fator de risco), permitem quantificar a magnitude (força) da associação entre duas variáveis (doença e fator). Algumas baseiam-se na diferença, outras na proporcionalidade entre as medidas de ocorrência do agravo e do fator.

\subsection{Risco}

As tabelas de contingência resumem os dados sobre a ocorrência do agravo e do evento. São tabelas de dupla entrada: as linhas correspondem às categorias de uma das variáveis, e as colunas, às da outra . Embora não exista limite, o número de categorias de cada variável não

Quadro 5 Medidas de ocorrência e de associações em estudos epidemiológicos*

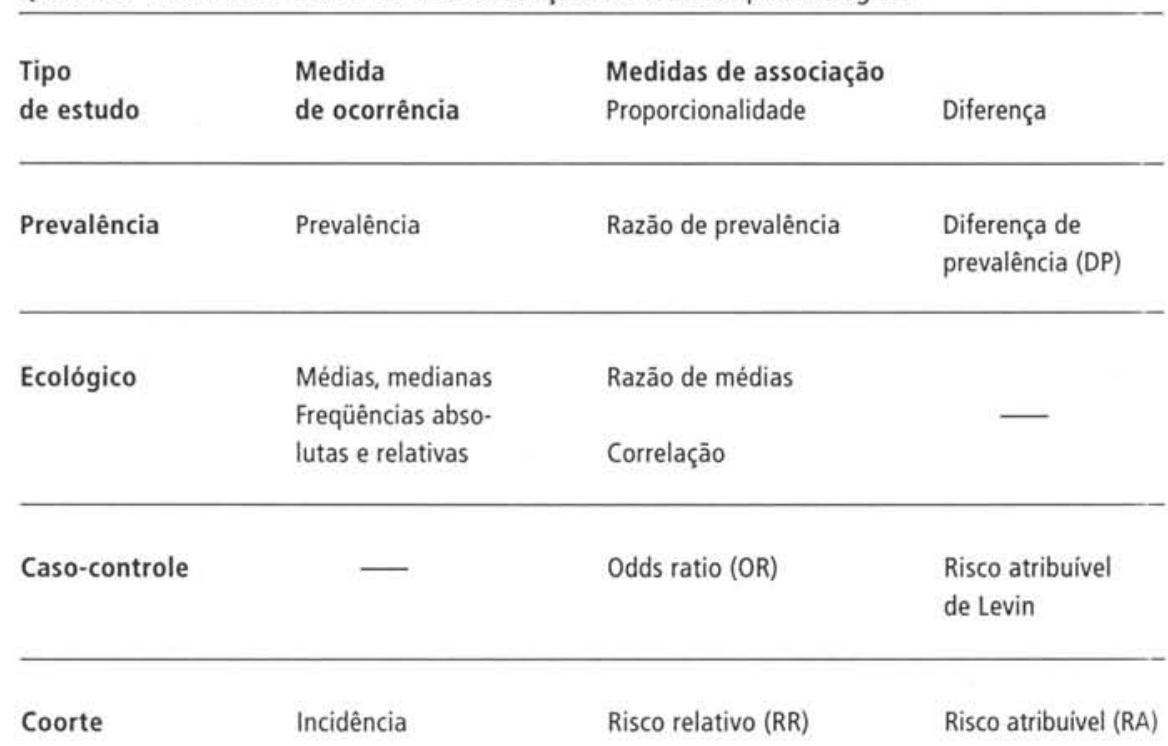

- Modificado de: Almeida FILHO, N. \& ROUQUAYROL, M. Z. Introdução à Epidemiologia Moderna. COOPMED/APCEI Abrasco, 2a edição, 1992. 
deve ser muito grande. Na maior parte das vezes trabalha-se com variáveis binárias (categóricas), e a tabela apresenta o seguinte formato genérico apresentado no Quadro 6.

Quadro 6 Tabela de contingência para duas variáveis binárias

\begin{tabular}{|l|c|c|c|}
\hline & Doentes & Não doentes & Total \\
\hline Expostos & $a$ & $b$ & $a+b$ \\
\hline Não-expostos & $c$ & $d$ & $c+d$ \\
\hline Total & $a+c$ & $b+d$ & $N=a+b+c+d$ \\
\hline
\end{tabular}

$\mathrm{I}_{\mathrm{e}}=\mathrm{a} /(\mathrm{a}+\mathrm{b})$ é $\mathrm{a}$ incidência de doentes entre os expostos, $\mathrm{I}_{0}=\mathrm{c} /(\mathrm{c}+\mathrm{d})$ é a incidência de doentes entre os não-expostos. $\ln =(a+c) /(a+b+c+d)$ é a incidência do agravo na população total.

As incidências da doença, no grupo dos expostos $\left(\mathrm{I}_{\mathrm{e}}\right)$ e no dos nãoexpostos $\left(\mathrm{I}_{0}\right)$, permitem estimar o risco de adoecer na presença e na ausência de exposição, respectivamente. Neste caso, o risco corresponde à probabilidade condicional (condicionada pelo fator de risco) de ocorrência de um determinado evento (adoecimento).

Nos estudos de coortes (e nos estudos de intervenção) grupos de sujeitos sadios, submetidos a diferentes níveis de exposição, são observados durante um período determinado, após o qual se verifica a presença, ou a ausência, do agravo; neste caso, a medida de ocorrência da doença corresponde ao coeficiente de incidência em cada grupo.

O Risco Relativo (RR) é a razão entre o coeficiente de incidência entre os expostos e o coeficiente de incidência entre os não-expostos. Um RR igual a 1 significa que $\mathrm{I}_{\mathrm{e}}=\mathrm{I}_{0}$, ou seja, não há associação; um RR igual a 5 significa que o risco de adoecer entre os expostos é 5 vezes maior do que entre os não-expostos.

O Risco Atribuível (RA) corresponde à diferença entre o coeficiente de incidência entre os expostos e o coeficiente de incidência entre os não-expostos; mede a porção da incidência que se pode atribuir à presença do fator estudado.

$$
R R=\frac{I_{e}}{I_{0}}=\frac{a /(a+b)}{c /(c+d)}
$$

$$
\begin{aligned}
& R A=I_{e}-I_{0} \\
& R A=a /(a+b)-c /(c+d)
\end{aligned}
$$

risco relativo

risco atribuivel 


$$
\mathrm{RAP} \%=\frac{\mathrm{I}_{\mathrm{n}}-\mathrm{I}_{0}}{\mathrm{I}_{\mathrm{n}}}
$$

Odds Ratio
O Risco Atribuível na População (RAP\%), expresso em percentagem, é uma medida de associação que leva em conta a freqüência da ocorrência do fator de risco na população. E mede a margem de excesso de morbidade que se pode atribuir à presença de um determinado fator de risco.

Nos estudos de caso-controle, em que se selecionam os grupos em função da presença ou ausência do agravo, não é possível determinar os coeficientes de incidência. Quando a freqüência do agravo na população total é muito baixa (situação em que são indicados os estudos de coortes) a e c são muito pequenos, e portanto $(a+b) \cong b$, e $(c+d) \cong d$. Neste caso, o risco relativo pode ser estimado pela relação denominada Odds Ratio ${ }^{41}$ (OR) ou razão de produtos cruzados, e se pode calcular o RAP\% através da fórmula de Levine (onde F é a proporção da população exposta ao fator de risco).
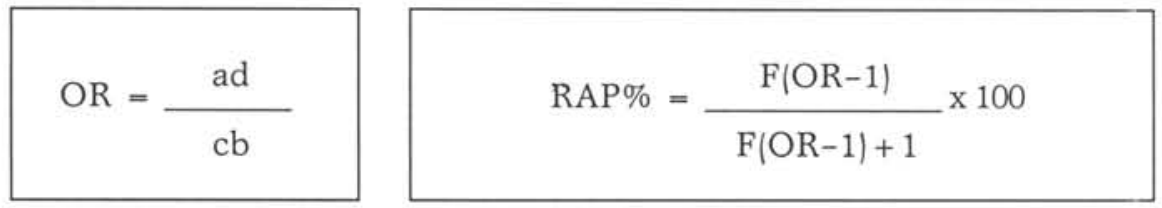

\subsection{Correlação linear}

É possível observar a associação entre duas variáveis quantitativas, graficamente, através do diagrama de dispersāo (Figura 11), sistema de eixos cartesianos em que a escala de valores de uma das variáveis $(\mathrm{X})$ corresponde ao eixo das abcissas, e a da segunda variável $(\mathrm{Y})$, ao eixo das ordenadas. As medidas de $\mathrm{X}$ e de $\mathrm{Y}$, tomadas em cada unidade de análise, fornecem um par de valores $(\mathrm{X}, \mathrm{Y})$. A "plotagem" do conjunto dos pares $(\mathrm{X}, \mathrm{Y})$ permite observar o comportamento conjunto das duas variáveis.

A variação concomitante das duas variáveis corresponde à correlação entre elas. Se as duas variáveis variam no mesmo sentido (quando $\mathrm{X}$ cresce $\mathrm{Y}$ também cresce), a correlação é dita positiva (direta); se X e $\mathrm{Y}$ variam em sentido contrário (quando $\mathrm{X}$ cresce $\mathrm{Y}$ decresce) a correlação é negativa (inversa).

Quanto mais dispersos os pontos, menor a correlação entre as variáveis, quanto mais concentrados (em torno de um eixo), maior a força de associação. Quando existe uma correlação linear perfeita entre as variáveis, o conjunto de pontos se alinha sobre uma reta.

\footnotetext{
${ }^{41} \mathrm{~A}$ OR é uma estimativa do risco relativo tão melhor quanto mais raro o evento.
} 


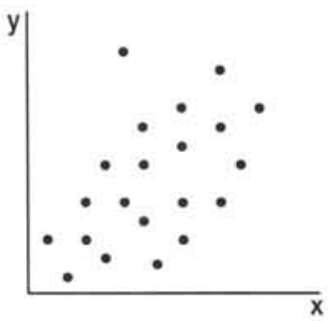

Correlação positiva fraca

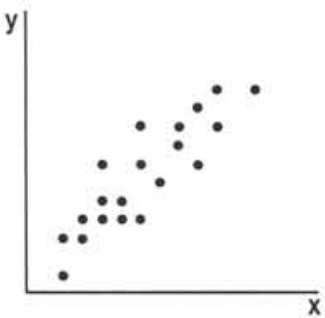

Correlação positiva forte

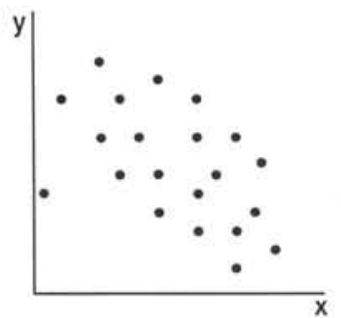

Correlação negativa fraca

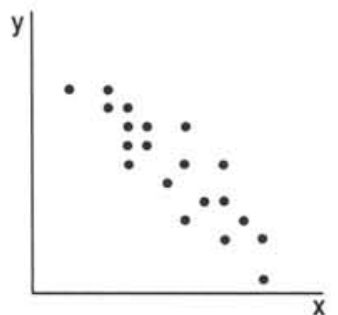

Correlação negativa forte

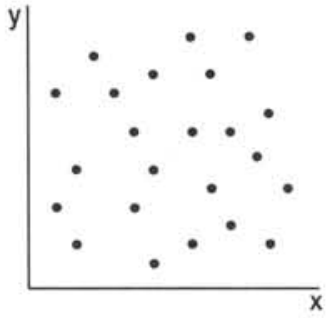

Ausência de correlação

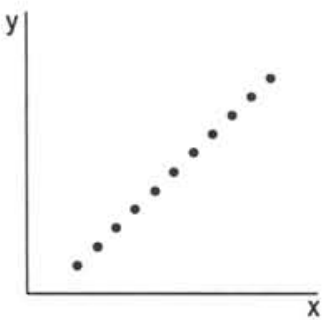

Correlação perfeita positiva
Embora não se possa usar a covariância $\left(S_{x y}\right)$ como medida do grau de correlação entre duas variáveis, pois a magnitude da mesma é função da ordem de grandeza das medidas (varia de $-\infty$ a $+\infty$ ), seu sinal (positivo ou negativo) acompanha o sentido da correlação

O coeficiente de correlação fornece uma medida do grau de correlação linear entre duas variáveis, e varia entre -1 e +1 . Um coeficiente de +1 indica uma correlação linear perfeita positiva $(y=a x+b)$, um coeficiente de -1 indica uma correlação linear perfeita negativa $(y=a x-b)$; quando não há correlação entre as variáveis, o coeficiente é zero. A escolha do coeficiente de correlação mais indicado é função da natureza das variáveis.

O coeficiente de correlação de Pearson (r) é freqüentemente empregado para avaliar a correlação entre variáveis contínuas.

$$
S_{x y}=\frac{\sum\left(X_{i}-\bar{x}\right)\left(Y_{i}-\bar{y}\right) f_{i}}{n}
$$
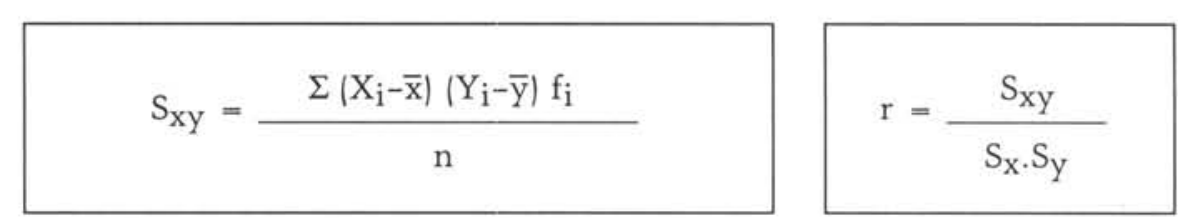

\section{coeficiente}

de correlação 
Observação: a existência de correlação não implica uma relação causal entre as duas variáveis. Freqüentemente, a variação concomitante de duas variáveis deve-se à influência de uma terceira.

\section{Medidas de significância estatistica}

As medidas de significância estatística correspondem à operacionalização de um critério estatístico para a aceitação da hipótese de que duas medidas $\left(\mathrm{M}_{1}\right.$ e $\left.\mathrm{M}_{2}\right)$, tomadas em circunstâncias diversas, diferem significativamente. Por exemplo, eficácia de um fármaco conhecido e eficácia de um fármaco novo em uma amostra; incidência conhecida da doença x em uma certa região e incidência da doença x medida em uma amostra de moradores de uma outra região; risco de adoecer da população não exposta a determinado fator e risco de adoecer em uma amostra de indivíduos expostos a determinado fator. Os testes de hipóteses não permitem provar uma hipótese, mas são úteis como instrumento para o estabelecimento de regras de decisão.

O primeiro passo consiste em formular duas hipóteses:

- a hipótese nula $\left(\mathrm{H}_{0}\right)$ afirma a igualdade entre as duas medidas (não há diferença). $\mathrm{H}_{0}: \mathrm{M}_{1}=\mathrm{M}_{2}$

- a hipótese alternativa $\left(\mathrm{H}_{1}\right)$ afirma a diferença entre as medidas.

A decisão sobre a diferença entre as duas medidas $\left(M_{1}\right.$ e $\left.M_{2}\right)$ restringe-se a duas possibilidades, e envolve duas espécies de erro (Quadro 7):

1) Considerar que $M_{1}=M_{2}$, o que significa aceitar $H_{0}$ e rejeitar $H_{1}$.

2) Considerar que $M_{1} \neq M_{2}$, o que significa aceitar $H_{1}$ e rejeitar $H_{0}$.

A probabilidade de ocorrência de um erro do tipo I, representada por $\alpha$, é o nível de significância do teste; a probabilidade de ocorrência de um erro do tipo II é representada por $\beta$.

A regra de decisão consiste em rejeitar a hipótese nula, (de que não há diferença) quando o resultado obtido da amostra $\left(\mathrm{M}_{2}\right)$, for pouco provável sob as condições de $\mathrm{H}_{0}$. Isto é, quando corresponder a valores extremos (limitados por $\alpha$ ) da distribuição teórica de probabilidades, associada a resultados calculados sob as condições de $\mathrm{H}_{0}$.

Em geral, fixa-se um valor para $\alpha$ (usualmente 0,05 ou menos), isto é, limita-se a probabilidade de se cometer um erro, do tipo I, de se aceitar que as duas medidas são significativamente diferentes, quando na verdade não o são.

Fixado $\alpha$ na distribuição das probabilidades de resultados sob as condições de $\mathrm{H}_{0}$, ficam determinadas:

- a região de rejeição de $\mathrm{H}_{0}$, que corresponde à dos resultados teoricamente mais prováveis. 
$\mathrm{H}_{0}$ é verdadeira

Aceitar $\mathrm{H}_{0}$

Aceitar $\mathrm{H}_{1}$
Não há erro

Erro Tipo I $(\alpha)$

Rejeitar $\mathrm{H}_{0}$ quando $\mathrm{H}_{0}$ é verdadeira
$\mathrm{H}_{1}$ é verdadeira

Erro Tipo II ( $\beta$ )

Aceitar $\mathrm{H}_{0}$ quando $\mathrm{H}_{0}$ é falsa

Não há erro

- a região de aceitação de $\mathrm{H}_{0}$, que corresponde à dos resultados considerados pouco prováveis, e que permitem aceitar a hipótese nula com uma probabilidade de erro igual a $\alpha$.

Se o valor da medida $\mathrm{M}_{2}$, obtido da amostra, estiver na região de rejeição de $\mathrm{H}_{0}$ (definida por $\alpha$ ), rejeita-se a hipótese nula ao nível de significância dado por $\alpha$; isto é, aceita-se que $M_{1}$ é diferente de $M_{2}$, com uma probabilidade de erro igual a $\alpha$.

Observação: o valor de $\beta$ depende do valor fixado para $\alpha$ e do verdadeiro valor da medida $\left(\mathrm{M}_{2}\right)$. Calculada a distribuição de probabilidade de resultados para um determinado valor (verdadeiro) de $\mathrm{M}_{2}, \beta$ corresponde à soma das probabilidades associadas aos resultados incluídos na região de aceitação de $\mathrm{H}_{0}$ (definida por $\alpha$ ).

- para n (tamanho da amostra) fixo, $\beta$ aumenta à medida que $\alpha$ diminui.

- para $\alpha$ e n fixos, o valor de $\beta$ diminui à medida que $\mathrm{M}_{2}$ verdadeiro se afasta de $M_{1}$.

- para $\alpha$ e $\mathrm{M}_{2}$ fixos, $\beta$ diminui à medida que a amostra cresce. 


\section{Referências bibliográficas recomendadas}

ABRANSON, J. M., 1990. Métodos de Estudio en Medicina Comunitátria. Madrid: Díaz e Santos.

ALMEIDA FILHO; ROUQUAYROL, M. Z. ,1992. Introdução à Epidemiologia Moderna. Rio: COOPMED/ APCE/Abrasco, 2a Edição.

BERQUÓ, E.S. et all., 1980. Bioestatística. São Paulo: EPU.

OPS/OMS, 1977. Manual para el control de las enfermidades trasmissibles. Washington DC: OPS/OMS, Pub. Cient., p. 564, 16» Edição.

OPS/OMS, 1988. El Desafio de la Epidemiologia. Washington DC: OPS/OMS, Pub. Cient., p. 505.

ROUQUAYROL, M. Z., 1988. Epidemiologia e Saúde. Rio de Janeiro: MEDSI.

VIEIRA, S., 1991. Introdução à Bioestatística. Rio de Janeiro: Campus. 


\section{Planejamento estratégico}

\section{Conteúdo}

Planejamento estratégico-situacional. Desenho e monitoramento de planos.

A leitura deve permitir:

- Reconhecer a importância do planejamento estratégico-situacional para o planejamento das ações de saúde, e o articular à construção de viabilidade de planos, ao monitoramento e à avaliação, em Vigilância Sanitária.

- Apreender a lógica do planejamento estratégico-situacional e de seus principais elementos teóricos e metodológicos - teoria da produção social, conceito de situação, problema, ator e outros; adquirir capacidade para aplicar esses elementos.

- Selecionar, descrever e explicar problemas de saúde, e desenhar planos estratégicos de intervenção sobre os mesmos. 



\section{Planejamento estratégico}

Marilene de Castilho Sá, Vera Lúcia Edais Pepe

\section{Introdução}

As imensas dificuldades, em nosso país, para as ações de Vigilância Sanitária serem efetivas podem ser melhor compreendidas se consideramos o alto grau de complexidade do objeto de intervenção das mesmas, e a baixa capacidade de regulação e controle do poder público sobre esse objeto. Assim, é necessário aumentar a governabilidade do Estado sobre as complexas e múltiplas variáveis intervenientes e relações presentes nos processos de produção, circulação e consumo de bens e prestação de serviços que interferem nas condições de saúde das populações e no meio ambiente.

Para atuar nesta área, com alguma probabilidade de êxito, leis, códigos sanitários, conhecimentos, tecnologias e recursos materiais são indispensáveis, mas insuficientes. É preciso ter poder e legitimidade para que leis e códigos sanitários se cumpram, para que conhecimentos e tecnologias sejam aplicados e recursos materiais estejam disponíveis e sejam adequadamente utilizados. Enfim, além de uma boa capacidade de governo (capacidade de fazer/saber fazer), a viabilidade (possibilidade de implementação) do projeto da Vigilância Sanitária está condicionada à possibilidade de um aumento considerável da governabilidade (grau de controle sobre as variáveis intervenientes no "jogo") do poder público sobre os processos sociais, políticos e econômicos que compõem o objeto de trabalho da Vigilância Sanitária.

Os conceitos de capacidade de governo, governabilidade, poder e viabilidade são alguns dos conceitos centrais do arsenal teórico-metodológico do planejamento estratégico-situacional, desenvolvido por Carlos Matus, um dos principais formuladores do enfoque estratégico de governabilidade 
enfoque normativo de planejamento planejamento na América Latina. Nesse enfoque, a escassez de recursos não diz respeito apenas aos recursos econômicos. O poder também é um recurso escasso, talvez o mais importante de todos, pois indispensável para a produção de mudanças na realidade social. A desconsideração dessa questão explica, em grande parte, os equívocos e fracassos das práticas tradicionais de planejamento econômico-social na América Latina, desenvolvidas segundo um enfoque tecnocrático e economicista, a que se convencionou chamar enfoque normativo de planejamento.

Em linhas gerais, este enfoque apresenta as seguintes características: 1) Dá primazia a categorias econômicas, como recursos, produção, produtividade, eficiência, custo-benefício econômico, etc; 2) Não reconhece as dimensões políticas que fazem parte da realidade sobre a qual se planeja, previlegiando a racionalidade técnica na orientação dos processos sociais de definição de prioridades e alocação de recursos; 31 Considera que apenas um ator planeja e que só existe uma explicação da realidade; 4) Considera ser possível prever e controlar os processos sociais através da racionalidade técnica; 5) Considera o plano uma norma a ser cumprida para se alcançar um objetivo, definido apenas através de critérios técnicos.

Muitas dessas características ainda persistem nos processos de planejamento e gestão do setor saúde. O planejamento é realizado em etapas separadas, de modo burocrático, raramente é executado e nunca avaliado. O esforço de captação de recursos nem sempre está voltado para atender as reais necessidades de saúde da população, a participação dos profissionais de saúde ainda é incipiente, e a participação da população ainda se restringe, quando muito, à representação de entidades civis nos Conselhos de Saúde. Nessa perspectiva, pode-se entender a profunda dissociação entre os processos formais de planejamento e o efetivo processo de tomada de decisão e de execução das ações em saúde.

Diante deste quadro, põe-se a seguinte questão: É possível o planejamento em saúde contribuir para a construção do SUS e, em particular, para o fortalecimento da Vigilância Sanitária?

Acreditamos que sim, embora o planejamento não seja uma fórmula mágica para a solução de problemas. O planejamento pode contribuir para ampliar a capacidade de governo e aumentar a governabilidade da Vigilância Sanitária. O enfoque estratégico de planejamento e, mais especificamente, a proposta metodológica do planejamento estratégicosituacional, aumenta o poder de explicação dos problemas e pode ajudar a sistematizar o raciocínio estratégico, muitas vezes realizado intuitivamente por quem governa.

O enfoque estratégico de planejamento social se desenvolveu, na América Latina, especialmente na segunda metade dos anos 70 , desde 
o reconhecimento dos limites do enfoque normativo para lidar com a complexidade, a contradição, a fragmentação e a incerteza características dos processos sociais. (Sá \& Artmann, 1994)

Entre os pressupostos e características gerais do planejamento estratégico podemos destacar:

- é um enfoque político, o poder é uma categoria de análise central.

- diferentes atores têm diferentes visões sobre a realidade, diferentes graus de poder e diferentes interesses. Não há um único sujeito do planejamento.

- não se podem fazer predições sobre a realidade social, pois é conflitiva e marcada pela complexidade e pela incerteza.

- planejar é realizar um cálculo sistemático, interativo (no sentido da relação com outros atores) e probabilístico. É um processo complexo e exige a articulação constante entre presente e futuro.

- os recursos econômicos não são os únicos recursos escassos. É necessário garantir "recursos de poder" para implementar as mudanças desejadas.

- o poder é uma capacidade, ou acumulação, capacidade de produção de fatos, capacidade de ação. Manifesta-se de várias formas - como um poder técnico, um poder político ou um poder administrativo. (Testa, 1995)

- planejar é um processo contínuo, sem separação rígida entre etapas, que se interpenetram. Este processo deve ser avaliado constantemente, em função do alcance da proposta de mudança. Planejamento e ação/execução são indissociáveis (planejar é governar).

\section{0 planejamento estratégico-situacional (PES)}

O texto que se segue se apóia, fundamentamente, nos trabalhos de Carlos Matus, idealizador do enfoque de planejamento estratégicosituacional (Matus, 1987, 1993, 1994-a, 1994-b, 1996-a, 1996-b). Este enfoque refere-se à arte de governar em situações de poder compartido, considera a existência de vários atores em um jogo de conflito e cooperação. Propõe-se a ser um método e uma teoria de planejamento estratégico público. E pode servir aos dirigentes, no governo ou na oposição, bem como a organizações da sociedade civil.

O PES não é só teoria e técnica, tampouco é um cálculo determinístico, com um só resultado possível. A teoria e os métodos são importantes mas insuficientes para um ator ter êxito na execução de seus planos. As habilidades pessoais, a experiência, a criatividade e a sensibilidade dos atores são importantes. Planejar também é arte, onde os problemas admitem distintas soluções, conforme os atores que os considerem.

\section{Carlos Matus}


recursos de cálculo

O planejamento estratégico-situacional é um cálculo que precede e preside a ação. Planejar é governar, é conduzir conscientemente os acontecimentos no rumo desejado. É transformar variáveis que não controlamos em variáveis que controlamos.

No entanto, a realidade social, por sua complexidade, resiste a ser conduzida, a ser governada, e não depende apenas de nossa ação. Há as ações dos outros atores, as surpresas, as manifestações da natureza, uma série de circunstâncias, previsíveis, sobre as quais não temos controle e outras que sequer somos capazes de imaginar.

Nesta luta contra a incerteza e na busca de governabilidade, o planejamento apresenta recursos de cálculo, que devem ser usados amplamente, de forma combinada. São eles:

- capacidade de predição: é o mais frágil de todos os recursos; pressupõe a capacidade de acertar numa só tentativa e numa só aposta sobre o futuro. Os planos tradicionais, sem cenários, operam apenas com este recurso. Nos sistemas que seguem leis, a capacidade de predição é alta, nos sistemas criativos, muito limitada.

- capacidade de previsão: um pouco menos frágil que a anterior. É, também, uma aposta sobre o futuro, mas não é cega; considera várias possibilidades de cenários, e formula, para cada um, um plano alternativo.

- capacidade de reação veloz ante as surpresas: significa capacidade de corrigir cálculos, de atualizar planos e de atuar velozmente. Tal capacidade, no entanto, não se consegue espontaneamente. Os sistemas de direção e gerência de qualquer organização devem estar preparados para reagir velozmente; essa reação só é possível com informação oportuna, em tempo eficaz, ou mesmo em tempo real. Assim, um bom sistema de monitoramento, que utilize sinais de atenção e alarme sobre o comportamento de indicadores, estrategicamente selecionados, tem muita importância.

- capacidade de aprendizagem com os erros: recurso fundamental para não se ter de pagar o preço da repetição de um erro. Tal aprendizagem tampouco é espontânea, e depende da potência de nossos métodos.

Estes recursos de cálculo só poderão ser efetivamente utilizados se acompanhados de uma mudança de mentalidades e de cultura nas organizações. É preciso, por exemplo, que os gestores se ocupem não só dos problemas atuais mas dos potenciais, isto é, levem também a sério os sinais de atenção, e atuem preventivamente. É preciso igualmente que, no dia a dia das organizações, haja domínio do plano sobre a improvisação, isto é, que as decisões se justifiquem, ou se fundamentem, em um plano. 
Todos os recursos de cálculo mencionados visam reduzir a margem de erro e melhorar a qualidade das ações. No entanto, a capacidade de agir, isto é, de produzir coisas, bens, serviços, idéias, conhecimentos, valores, leis, enfim, a capacidade de produzir fatos sociais, depende, essencialmente, dos recursos disponíveis e da habilidade para os utilizar bem.

Em planejamento estratégico-situacional, os recursos se agrupam em quatro categorias ou tipos: econômicos, cognitivos (conhecimentos, saberes, valores, tecnologias, experiências, informações, etc.), organizativos (infra-estrutura, apoio logístico ou operacional, modelos ou estruturas organizacionais, redes de comunicação, etc.) e políticos (votos, apoios, adesões, afiliações, carisma, capacidade de influenciar ou poder de tomar decisões, etc.).

Esses recursos são escassos, e constituem capacidades de produção. Ao serem utilizados na produção de ações, podem contribuir para aumentar ou para diminuir a capacidade de produção do ator que os utiliza, e gerar novas acumulações ou, ao contrário, desacumulações. Tudo depende da forma de administrar os recursos e dos resultados das ações produzidas com os mesmos.

Assim, conduzir ou planejar é fazer um cálculo permanente de vários recursos escassos (Figura 1).

Figura 1 Produção de fatos sociais (acumulação/desacumulação) recursos

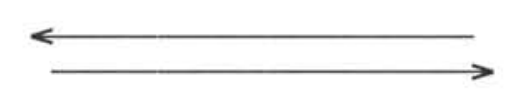

Recursos

Fatos sociais

0 ator e 0 triângulo de governo

Um ator social é uma organização e, em alguns casos, até mesmo uma pessoa/uma personalidade. Um ator social cumpre os seguintes requisitos: tem um projeto político; controla algum recurso relevante, ou variáveis importantes para a situação; tem força e, por conseguinte, tem capacidade de produzir fatos no "jogo social"; tem organização estável ou, no caso de uma personalidade, tem uma presença forte, capaz de influenciar/conduzir um coletivo social. 
Governar exige a articulação constante de três variáveis:

- projeto de governo $(\mathrm{P})$ : refere-se ao conteúdo propositivo do projeto de ação, ou plano, que um ator visa implementar para alcançar seus objetivos (o que fazer).

- capacidade de governo $(\mathrm{C})$ : é uma capacidade de condução ou direção (capacidade de fazer). Refere-se ao acervo de técnicas, métodos, habilidades e experiências de um ator, e de sua equipe de governo, para conduzir o processo social a objetivos determinados, dados a governabilidade do sistema e o conteúdo propositivo do projeto de governo.

- governabilidade do sistema (G): é uma relação entre as variáveis que o ator controla, e não controla, no processo de governo, ponderadas pelo valor, ou peso, dessas variáveis para a ação do ator. Quanto mais variáveis decisivas o ator controla, maior é a sua liberdade de ação e maior sua governabilidade sobre o sistema.

A interdependência destas variáveis se representa, graficamente, como um triângulo, como na Figura 2.

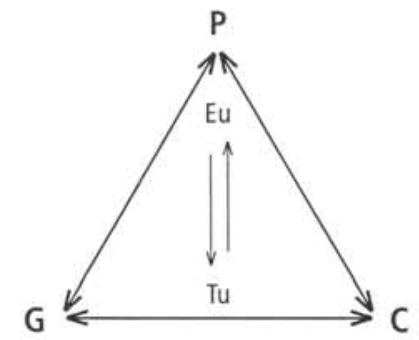

A relação "Eu-Tu", no centro do triângulo, é uma referência à necessidade de se considerar a situação dos demais atores na articulação das variáveis.

Examinando a dinâmica do triângulo de governo, podemos observar:

- qualquer que seja a posição ocupada por um ator (seja ele coordenador de um sistema estadual ou municipal de Vigilância Sanitária, ou Secretário de Saúde) o conteúdo propositivo de seu Projeto de governo (de seu plano) e sua qualidade não são produtos, apenas, das circunstâncias em que este ator se encontra, dos problemas que enfrenta e de seus interesses, mas também de sua Capacidade de governo. Inclui-se aí sua capacidade de selecionar corretamente os problemas a serem 
enfrentados, aprofundar a explicação dos mesmos e propor soluções criativas e eficazes. Por outro lado, a possibilidade de realização de um projeto de governo depende da Governabilidade do ator sobre o sistema; quanto mais ambicioso o projeto, maiores as exigências de Governabilidade para implementá-lo.

- a Governabilidade depende do ator em questão, das exigências postas por seu Projeto de governo e de sua Capacidade de governo. A realidade não é igualmente governável para os distintos atores, pois eles controlam diferentes proporções de variáveis do sistema e têm Projetos com diferentes graus de ambição. Além disso, quanto maior for a Capacidade de governo de um ator, maior será a Governabilidade do sistema para ele.

- assim, por exemplo, um projeto de fortalecimento do Sistema de Vigilância Sanitária de um Estado, que proponha um maior controle sobre as atividades dos laboratórios farmacêuticos, tende a exigir maior Governabilidade para sua implementação do que um projeto que apenas redistribua, entre o Estado e os Municípios, responsabilidades e competências. Por sua vez, a Governabilidade para a execução daquele mesmo projeto é, em tese, maior para o ator Governador do Estado do que para o ator Coordenador Estadual da Vigilância Sanitária.

- a Capacidade de governo pode ser definida como capacidade de gerar e controlar ações, e se expressa na capacidade de direção e de gerência. Neste sentido, o domínio de técnicas potentes de planejamento é um dos fatores mais importantes na determinação da Capacidade de governo de uma equipe. Buscar ampliar a Capacidade de governo como meio para definir projetos eficazes, e para aumentar a Governabilidade para implementá-los, devem ser as preocupações centrais de um ator.

\section{0 conceito de situação e o processo de produção social}

Quando se está imerso numa problemática de governo ou de gerência, isto é, numa situação de ter que tomar decisões e produzir ações que transformem a realidade, enxergam-se problemas e oportunidades para enfrentá-los. Problemas que não se circunscrevem a um único setor - como o da saúde ou educação - e tampouco podem ser explicados por uma única disciplina científica.

Além disso, a produção de um fato num domínio, ou setor, da realidade tem conseqüências em outros setores. Portanto, mesmo quando se atua em um único setor, como o da saúde, é preciso saber avaliar e tentar governar, também, as conseqüências dessas ações em outros setores. 
explicação situacional

Teoria da Produçăo Social
Assim, diante da necessidade de uma apreciação de conjunto da realidade, de uma visão mais integradora, que, ao mesmo tempo, destaque as partes relevantes para a ação do ator que a considera, o planejamento estratégico-situacional (PES) lança mão do conceito de situação e da noção de produção social. E busca construir uma Teoria da Produção Social.

A situação é uma apreciação de conjunto da realidade, feita por um ator, considerando as ações que pretende realizar para alcançar seus objetivos. A explicação situacional se diferencia do diagnóstico tradicional por ser uma análise da realidade dirigida para a ação. Para ser eficaz, essa análise deve conter os aspectos relevantes para a ação do ator.

Assim, o conceito de situação permite articular conhecimentos provenientes das ciências às experiências e percepções dos atores no momento de sua ação.

O conceito de situação remete à idéia de se estar numa situação, de se conhecer e explicar uma realidade de dentro da mesma, ou a partir de uma situação. A situação é o que dá significado à ação de um ator, o significado não existe fora da situação. Não podemos compreender a ação do outro se não nos colocarmos em sua situação, e entendermos como ele explica a realidade. Isto é de fundamental importância para o planejamento estratégico, pois para lidar eficazmente com o outro é preciso conhecer suas motivações e se antecipar às suas ações, que dependem de sua explicação situacional, seja ela verdadeira, falsa, racional ou irracional, segundo nosso ponto de vista.

Assim, diferentemente do diagnóstico tradicional de planejamento a explicação situacional é, ao mesmo tempo, "totalizante" e seletiva (é uma apreciação de conjunto, que destaca apenas as partes relevantes para a ação do ator), auto-referencial e policêntrica (está referida a um ator e a sua situação, mas considera as visões dos demais atores importantes para a manutenção, ou para a solução dos problemas).

Do mesmo modo, a Teoria da Produção Social também permite uma visão integral da realidade, além de uma explicação aprofundada dos problemas e suas causas.

O conceito de produção social abrange tudo que o homem cria (valores, ideologias, organizações, instituições, partidos políticos, normas, ciências, arte, etc), a partir de uma diversidade de recursos de naturezas distintas (econômicos, cognitivos, políticos, organizativos). Todos esses recursos, e as formas como os mesmos se organizam, constituem as capacidades de produção (ou acumulações) sociais. Todos os fatos ou fenômenos que podem ser produzidos, isto é, todos os fluxos de produção, bem como todas as capacidades de produção ou acumula- 
ções, encontram-se num espaço de variedade do possível, definido pela regras básicas do processo de produção.

O processo de produção social pode ser comparado a um jogo. É criativo, conflitante, é quase impossível predizer as jogadas, que equivalem às ações dos atores sociais, que lançam mão de seus recursos (suas "cartas") para produzirem suas jogadas. Através dessas jogadas (dos fluxos de produção) os jogadores (atores) acumulam ou desacumulam recursos, isto é, podem aumentar ou diminuir suas capacidades de produção.

Um jogo possui regras, assim como o sistema social. Essas regras básicas definem as acumulações e fluxos de produção possíveis. No sistema social, estas regras básicas definem, em última instância, os sistemas jurídico-político, econômico e cultural/ideológico. Não se constituem apenas de leis e normas formais, escritas, mas também de hábitos, valores, tradições, etc. Uma diferença importante entre o jogo e o sistema social é que neste último as regras não são tão rígidas e imutáveis. No sistema de produção social as regras podem ser mudadas, embora através de "jogadas"/ações/fluxos que exigem muitos recursos (especialmente políticos). De todo modo, as regras básicas do sistema social são muito estáveis, pois os atores sociais mais fortes as sustentam e defendem.

O processo de produção social pode ser representado como o circuito da Figura 3.

Figura 3 Processo de produção social

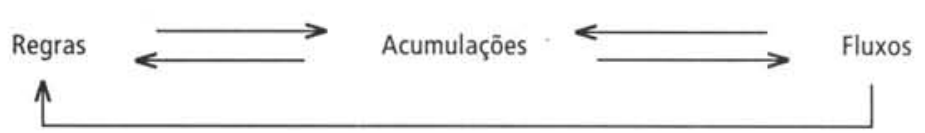

Os atores ("jogadores") são "acumulações humanas" e possuem também acumulações de vários tipos. Ao longo do processo de produção social os atores acumulam habilidades, conhecimentos, experiências, assim como desenvolvem valores, sentimentos e outras capacidades de produção. Estas acumulações sociais definem a variedade possível de "jogadas"/ações (fluxos de produção). Assim, quanto mais ricas e amplas as acumulações de um ator social, maiores suas possibilidades de movimento, mais diversas suas opções de ações, isto é, de produção de fatos. 
Resumindo, podemos dizer que:

- a Teoria da Produção Social nos ensina a olhar a realidade para além dos fatos, ou dos fenômenos sociais, que se encontram na superficie e que fluem como produção; esse é o plano dos fluxos de produção social. Alguns fatos, ou fluxos, se acumulam como novas capacidades de produção social. Por exemplo, um investidor da bolsa de valores realizou uma operação de compra de ações (fluxo) bem sucedida e duplicou sua fortuna (aumentou sua capacidade de produção, suas acumulações). Outros fatos/fluxos, mais raros e muito exigentes de recursos, criam ou alteram as regras básicas. A aprovação (fluxo) da "lei dos genéricos" exigiu muita articulação e negociação política (muitos recursos políticos), pois contrariava interesses poderosos. Esta lei poderá influenciar a lógica (regras) de comercialização de medicamentos no país.

- todos os fluxos de produção são gerados pelas capacidades acumuladas do sistema. Estas constituem um segundo plano de análise da realidade: o plano das acumulações sociais ou capacidades de produção. Uma fábrica, por exemplo, é uma acumulação que produz bens; um hospital, uma acumulação que produz serviços médicos. Um deputado é uma acumulação social em função das experiências, saberes, informações que tem como indivíduo e do poder e legitimidade que possui, em virtude de sua carreira política e do mandato que exerce. Este mesmo deputado também pode possuir acumulações sociais como, por exem. plo, ser dono de um jornal e ter um grande capital financeiro. Além disso, também pertence a outras acumulações sociais - a seu partido político e a um sindicato, por exemplo - e se relaciona com muitas outras acu. mulações. Podemos dizer que o peso de um ator (sua força) é uma função das acumulações que ele é, que ele possui, às quais pertence e com as quais se relaciona. As relações de força entre os atores explicam a manu. tenção, ou a mudança das regras básicas do sistema de produção social.

- o terceiro plano é o plano das regras básicas, que são um produto social, um produto dos atores. São as regras que determinam o espaço possível de produção do "jogo social", isto é, os tipos de acumulações ou capacidades de produção possíveis e, consequentemente, os fluxos de produção possíveis. Por exemplo, o monopólio do Estado na prestação de serviços de saúde é uma acumulação situada fora do espaço de possibilidades criado pelas atuais regras que regem o Sistema Único de Saúde no Brasil. Existe um reforço mútuo entre as regras básicas do sis. tema e as relações de força entre os atores (acumulações).

Que importância tem tudo isso para o planejamento em saúde, particularmente, na Vigilância Sanitária? A Teoria da Produção Social tem importância porque ensina a identificar as causas dos problemas nos diversos planos da realidade e o grau de dificuldade para sua transfor- 
mação. É muito mais fácil mudar fluxos de produção do que acumulações. E estas últimas, se comparadas às regras básicas, são mais fáceis de mudar.

Imaginemos o problema da fraude e da falsificação de medicamentos. Se nos pusermos no lugar (na situação) de um Secretário Estadual de Saúde (ator) comprometido com a melhoria do sistema de Vigilância Sanitária de seu Estado, tal problema poderá manifestar-se, ou ser detectado, através dos seguintes fatos (fluxos de produção):

- lotes de $n^{2} \ldots$ a ..., do medicamento $X$ não contêm o princípio ativo constante de sua fórmula;

- lote $n^{2} . .$. , do medicamento Y não traz na embalagem a quantidade especificada de comprimidos;

- apreensão, nas farmácias $A, B$ e $C$, de todo o estoque de um medicamento denominado $Z$, de cuja embalagem não consta a identificação do farmacêutico responsável, nem o CGC da indústria produtora, nem o registro do produto no $M S$.

Ora, em sua explicação para estes fatos, o Secretário de Saúde pode levantar, entre outras, as seguintes causas (situadas no plano dos fluxos, das acumulações ou das regras):

- parte do comércio varejista comercializa medicamentos populares a preços inferiores aos do mercado, sem controle de procedência, e sem condições de armazenagem e transporte; (fluxo de produção).

- alguns distribuidores e revendedores comercializam, conscientemente, produtos de laboratórios clandestinos; (fluxo de produção).

- existe venda generalizada de medicamentos sem receita médica; (fluxo de produção).

- há desvio, e comércio, de refugos de grandes laboratórios; (fluxo de produção).

- a população não tem informação sobre os riscos da automedicação, ou sobre medidas que possam ajudá-la a identificar medicamentos de qualidade duvidosa (acumulação);

- grande parte das farmácias e drogarias não dispõe de farmacêuticos responsáveis durante seu horário de funcionamentos (acumulação);

- grande parte das farmácias e drogarias não possui rotinas de verificação e controle das condições dos medicamentos que recebe (acumulação);

- parte das indústrias não possui sistema eficiente de controle e eliminação adequada de refugos (acumulação);

- as condições materiais e de recursos humanos da Vigilância Sanitária, no Estado, são precárias (acumulação);

- parte das farmácias e drogarias escolhem distribuidores tendo como critério apenas o preço dos medicamentos (a lógica do lucro domina o comércio de medicamentos, em detrimento da qualidade dos mesmos) (regra); fraude e falsificação de medicamentos 
- as atividades de Vigilância Sanitária nunca foram uma prioridade entre os investimentos do setor público de saúde (regra);

- a corrupção no poder público, inclusive no judiciário, ainda é um grande obstáculo às ações da Vigilância (regra;)

- em nossa sociedade, a saúde é um produto comercial e muito rentável (regra).

Enfrentar essas várias causas pode apresentar diferentes graus de dificuldade. Assim, se nosso Secretário de Saúde quiser enfrentar o problema da fraude/falsificação de medicamentos deverá, por exemplo, intensificar as ações de fiscalização sanitária sobre $a$ distribuição $e$ a revenda de medicamentos, e tentar intervir sobre a maioria das causas identificadas no plano dos fluxos de produção. Ao mesmo tempo, o Secretário sabe que esta operação, embora importante, não é suficiente para eliminar grande parte das causas do problema. E que precisará, também, readequar a estrutura material e de recursos humanos da Vigilância Sanitária (acumulação) para ter condições de ampliar as ações de fiscalização e monitoramento da qualidade do sistema de produção industrial (outra acumulação). Estas operações, no entanto, são mais complexas que a primeira (fiscalização da distribuição e revenda de medicamentos), e exigem maior capacidade de governo e maior governabilidade.

O Secretário percebe, também, que, para enfrentar o problema de modo definitivo, precisará atuar sobre causas que se situam no plano das regras, muito difíceis de mudar, e, em sua maioria, fora de seu controle. Ele tem algum controle sobre a primeira e a segunda regras, e, talvez, possa levar a efeito algumas operações de regulação da relação entre distribuidores e revendedores de medicamentos. E ainda pode pressionar o Governador, e o poder legislativo estadual, com vistas a obter maior dotação orçamentária para a saúde, em particular para as atividades de Vigilância Sanitária. Mas sabemos o quanto essas discussões são permeadas por interesses vários, com freqüência difíceis de compatibilizar.

Assim, a Teoria da Produção Social pode contribuir para haver mais clareza quanto às limitações e possibilidades de mudança da realidade. Muitas vezes nos propomos objetivos que representam fluxos de produção impossíveis de serem produzidos dentro do permitido pelas regras básicas do jogo social, do qual participamos. Outras vezes, tentamos resolver um problema no nível dos fluxos de produção, quando suas causas essenciais encontram-se no plano das acumulações. Em outras, ainda, queremos mudar regras situadas fora de nossa capacidade de produção, isto é, de nossas acumulações, de nossas forças. 
Reconhecer os limites e as possibilidades, nesses três planos, não significa acomodação aos limites. A estratégia é desencadear um processo pela produção de fatos situados dentro do espaço de nossas capacidades atuais e que podem ampliar esse espaço.

Os problemas não serão bem analisados nem bem resolvidos se não identificarmos adequadamente as causas nos diferentes planos. Atuar deliberadamente no plano dos fluxos de produção, enquanto não temos força para atacar causas importantes de um problema no plano das acumulações ou das regras, é diferente de atuar apenas no primeiro nível porque não soubemos explicar bem o problema.

O planejamento estratégico-situacional também considera ser possível representar a realidade social no espaço geral (da sociedade, de um país, do governo federal), no espaço particular (de um setor, como o da saúde, de um ministério, de um governo estadual) e no espaço singular (de um município, de um hospital, de uma associação de moradores, de uma família).

Em cada espaço, a descrição e a explicação do problema, os atores participantes e as possibilidades de enfrentamento são distintas. As regras, acumulações e fluxos de produção adquirem diferentes especificidades, mas o que ocorre no espaço singular depende das regras, acumulações e fluxos que ocorrem nos espaços particular e geral. A forma como um ator divide a realidade em espaços depende de seus propósitos e de sua capacidade de ação.

Assim, o problema da fraude e da falsificação de medicamentos pode ser tratado no espaço singular de uma coordenação estadual/municipal de Vigilância Sanitária, como um problema de descontinuidade das ações de fiscalização sanitária; no espaço particular do Ministério da Saúde, pode ser tratado como problema de precariedade do Sistema de Vigilância Sanitária, ou ainda ser trazido para o espaço geral dos grandes problemas nacionais, e ser tratado como um problema de baixa capacidade de regulação e controle do Estado sobre a produção privada.

Ante esses diferentes espaços, um ator pode circunscrever um problema ao âmbito de suas capacidades de ação e, ao mesmo tempo, reconhecer os limites das explicaçōes e intervenções que se pode realizar a partir desse espaço. Não adianta discutir um problema apenas no espaço mais geral da sociedade, se não há capacidade de atuar neste nível. Freqüentemente, os problemas têm tamanha especificidade que, para se ser bem sucedido na explicação e na intervenção sobre os mesmos, é preciso trazê-los para seu espaço particular, ou específico, de análise, onde poderão ser aprofundados. Tal procedimento não impede a consideração das causas mais gerais do problema, como "pano de fundo" para a análise, atitude aliás, recomendável. 


\section{A proposta metodológica do planejamento estratégico-situacional (PES)}

Os conceitos até aqui apresentados são a base para se entender o método PES. Ao contrário dos métodos tradicionais de planejamento, o PES não se apoia em etapas, rigidamente delimitadas e ordenadas no tempo, mas utiliza-se da noção de momento. O planejamento é um processo contínuo, em cadeia, sem começo ou fim definidos. E a noção de momento remete à de "instância", "ocasião", "circunstância" ou "conjuntura", a dominar, transitoriamente, o processo.

Assim, num processo real de planejamento e gestão, cada momento compreende os demais. Ao mesmo tempo em que se explica um problema (momento explicativo), já se tem uma idéia, ainda que preliminar, dos resultados desejados (momento normativo), já há uma avaliação preliminar dos atores favoráveis, ou contrários, ao enfrentamento do problema e do grau de dificuldade política para enfrentá-lo (momento estratégico) e, às vezes, a execução de algumas ações já se iniciou (momento tático-operacional). Além disso, no dia a dia de uma organização, como uma Secretaria de Saúde, o processo de planejamento e gestão enfrenta problemas em diferentes momentos: enquanto alguns problemas ainda estão sendo analisados, para outros já se desenha um plano de intervenção e para outros tal plano já se encontra em execução.

Os quatro momentos do processo de planejamento estratégicosituacional são os seguintes:

- momento explicativo: o ator, ou os atores, identificam os problemas, selecionam os que deverão enfrentar imediatamente e procuram compreender (explicar) como tais problemas se manifestam, por que existem, como foram gerados; isto é, quais suas causas, e quais suas conseqüências. As causas de um problema se articulam, se reforçam mutuamente, formando uma rede de causalidade.

- momento normativo: definem-se os resultados a que se quer chegar, a partir do enfrentamento dos problemas selecionados, o que se deve fazer (operações/ações) para alcançar tais resultados, os recursos (de vários tipos) necessários para a realização das operações, os responsáveis pelas mesmas, entre outros aspectos; esse, portanto, é o momento de desenho do plano de intervenção sobre os problemas.

- momento estratégico: analisa-se o grau de dificuldade (viabilidade) para realizar as operaçōes e alcançar os resultados. Para isto, examinam-se as posições (motivações) dos atores relevantes e sua capacidade (poder) de facilitar, ou dificultar/impedir, a realização das operações. $\mathrm{O}$ mais importante é que este momento não se limita à análise de viabili- 
dade, mas inclui a busca de estratégias - como a negociação cooperativa, a persuasão, o uso de autoridade e até mesmo, em alguns casos, o confronto - visando a construção de viabilidade para as operações consideradas inviáveis na análise inicial.

- momento tático-operacional: é o momento de execução do plano. O grande desafio é garantir a coerência entre as decisões do dia-a-dia e os objetivos de médio/longo prazo do plano. O PES propõe um sistema de gestão estratégica que se apóia, entre outros mecanismos, num processo de gerência por operações, com petição e prestação de contas regularmente realizadas pelos responsáveis por cada operação e ação. A execução do plano, e a conjuntura, são monitorados através de um sistema de indicadores e sinais de atenção e alarme, que permitem ao gestor corrigir possíveis erros de condução, e/ou antecipar problemas não previstos. O sistema de gestão estratégica propõe um controle sobre a agenda do dirigente (distribuição do tempo e dos compromissos), para se evitar dispersão com problemas de menor valor estratégico.

Apresentaremos, a seguir, a proposta metodológica de cada um desses momentos.

\section{Momento explicativo}

A explicação de uma realidade, ou de um problema, será sempre situacional, isto é, referida a um ator e a sua situação. Ao fazer uma apreciação da realidade, um ator focaliza apenas as partes relevantes (estratégicas) para seus propósitos de ação. Por isso, a explicação situacional é seletiva. Nesta apreciação da realidade, um ator identificará problemas e oportunidades, que serão explicados segundo sua visão de mundo, seus valores, seus conhecimentos e experiências e também segundo o que ele julga ser o ponto de vista de outros atores relevantes. Por isso a explicação situacional será, ao mesmo tempo, auto-referencial e policêntrica.

Uma noção fundamental para toda a proposta do PES é a noção de problema, que pode ser caracterizado como:

- uma realidade insatisfatória para um ator;

- uma discrepância entre o que a realidade é hoje lou o que pode vir a ser) e o que deve ser (ou deveria ser);

- relativo à posição de um ator (o problema para uns pode não ser problema para outros; um problema muito importante para um ator, pode não ser tão importante para outro);

- uma realidade inaceitável, e evitável, do ponto de vista de um ator (os atores só se mobilizam contra o que julgam evitável, contra o inevitável não se luta);

problema 
- uma declaração, claramente definida/descrita por um ator, distinta de um mero mal-estar (impreciso, ambíguo, indefinido).

Os problemas podem ser de vários tipos:

1) Problemas bem estruturados ou problemas quase estruturados: os primeiros são problemas cujos fatores, variáveis intervenientes e soluções são finitos, conhecidos e aceitos por todos. De fronteiras bem delimitadas, esses problemas não se misturam a outros, nem geram, com sua solução, outros problemas.

Os problemas sociais e, particularmente, os problemas de saúde, são do segundo tipo. São complexos, quase estruturados, não é possível enumerar todas as suas variáveis intervenientes nem definir, com precisão, o peso das mesmas na determinação desses problemas e as relações que estabelecem entre si. As possibilidades de solução desses problemas são infinitas, e criadas pelos próprios homens, em situação. Não há soluções ótimas ou aceitas igualmente por todos os envolvidos. Tais problemas se encontram sempre entrelaçados a outros e sua solução pode facilitar, ou criar, dificuldades para a solução de outros problemas.

2) Problemas atuais ou problemas potenciais: os primeiros são aqueles cujas manifestações e conseqüências se fazem sentir no presente, enquanto os segundos são tendências ou possibilidades, cujos resultados se manifestarão no futuro. Um gestor, em qualquer nível de direção, deverá ocupar-se não apenas dos problemas atuais, como também saber identificar e antecipar os problemas potenciais, sob pena de imediatismo na gestão.

3) Problemas terminais ou problemas intermediários: os primeiros se manifestam diretamente para a população como uma insatisfação, necessidade ou demanda; os segundos surgem no interior das instituições e dizem respeito à organização, e/ou aos processos internos às mesmas. $\mathrm{Na}$ área de saúde, por exemplo, um problema de baixa qualidade da assistência em um hospital é um problema terminal (ou final), e a ineficiência dos mecanismos de gerência do hospital, um problema intermediário; um gestor deve saber identificar tanto um quanto outro tipo de problema.

O momento explicativo começa com a seleção dos problemas. Um mesmo ator poderá identificar um número interminável de problemas, sobre os quais não terá capacidade de intervir ao mesmo tempo. É preciso, então, saber concentrar a atenção nos problemas efetivamente estratégicos para o ator. Isto é, aqueles que, se enfrentados, poderão abrir caminho para os propósitos de mudança do ator - e que requerem a intervenção direta do mesmo.

A seleção de problemas é de fundamental importância. Um Plano Municipal de Saúde baseado em uma seleção mal feita de problemas, 
será um plano fraco, e dificilmente terá impacto favorável sobre a situação de saúde da população.

O PES propõe alguns critérios para a seleção de problemas, entre os quais destacamos os seguintes, com algumas adaptações:

- valor político do problema para o ator central, para os atores que o apoiam e para a população em geral; o valor atribuído ao problema costuma ser hierarquizado em "alto", "médio" ou "baixo";

- tempo de maturação dos resultados dentro, ou fora, do período de governo. Busca-se um equilíbrio na montagem do plano, evitando-se voltá-lo apenas para problemas atuais e de resultados imediatos ou, ao contrário, concentrá-lo, em demasia, em problemas cujos resultados das intervenções só aparecerão após o período de gestão do ator;

- recursos exigidos para o enfrentamento do problema - recursos políticos, econômicos, cognitivos ou organizativos, na dependência de quais são necessários para o enfrentamento do problema. Examina-se o equilíbrio entre o conjunto de recursos necessários e os recursos controlados pelo ator/gestor. Se o problema for relevante, deve-se buscar viabilizar a consecução dos recursos necessários para solucioná-lo. O plano não deverá, por uma questão de eficácia política, ser composto apenas por problemas cujos recursos necessários estejam totalmente fora de controle do ator.

- governabilidade do ator sobre o problema (alta, média ou baixa, conforme o grau de controle do ator sobre as principais causas do problema). Com este critério também se procura um equilíbrio no plano e não a exclusão de problemas cujas causas, a princípio, estejam fora do controle do ator. Pois a governabilidade de um ator sobre determinado problema pode ser ampliada.

- resposta dos atores com governabilidade. Os demais atores relevantes para o problema podem ter ou não interesse na solução do mesmo, concordar ou não com a solução proposta, ou até mesmo ignorar o problema. Neste sentido, as possíveis respostas destes atores são classificadas como: apoio (ou colaboração); rechaço (ou rejeição); e indiferença. Ao classificar tais respostas, o ator central está tentando colocar-se no lugar do outro. Assim como nos dois critérios anteriores, este é um cálculo preliminar dos limites e possibilidades de enfrentamento do problema.

- custo de postergação. Refere-se ao "preço" econômico, social ou político a se pagar, se o problema não for selecionado entre os que sofrerão intervenção imediata (custo do adiamento da solução do problema); tal custo costuma ser classificado como alto, médio ou baixo e, ainda, imediato ou mediato.

- impacto sobre as condições de saúde da população. É a importância da solução do problema para a melhoria das condições de saúde da 
explicação do problema

\author{
Vetor de Descrição \\ do Problema
}

população ou, pelo menos, o impacto da solução do problema na qualidade da assistência à população. (Artmann et alli, 1997).

A decisão de se selecionar, ou não, um problema não pode levar em conta apenas os resultados isolados da aplicação desses critérios sobre o mesmo. É preciso examinar a situação do conjunto dos proble. mas com relação aos critérios, e buscar um equilíbrio, no futuro plano, entre problemas de diversos tipos.

Feita a seleção dos problemas, o próximo passo é explicá-los. Uma explicação de um problema deve começar pela descrição do mesmo. Não basta dizer o nome do problema, pois um mesmo nome pode receber diferentes significados, e gerar, em conseqüência, explicações diversas, e distintos planos de intervenção. Portanto, é preciso definir claramente quais os fatos, fenômenos ou sinais que caracterizam o problema e permitem que um ator o reconheça, e o declare, como tal.

Estes fatos, ou fenômenos, esses sintomas do problema, são chamados descritores. O conjunto de descritores de um problema recebe o nome de Vetor de Descrição do Problema (VDP). O ator deve considerar necessário cada descritor e o conjunto de sintomas suficiente para caracterizar o problema como tal.

Tomando o exemplo do problema "Fraude e Falsificação de Medicamentos", temos, como Vetor de Descrição do Problema, os seguintes descritores: D1: lotes de ne ... a ..., do medicamento $X$ não contêm o princípio ativo constante da fórmula; D2: lote $n^{2} \ldots$, do medicamento $Y$ não trazem na embalagem a quantidade especificada de comprimidos; D3: apreendeu-se nas farmácias $A, B$ e $C$ todo o estoque de um medicamento denominado $Z$, de cuja embalagem não consta a identificação do farmacêutico responsável, nem o CGC da indústria, nem o registro do produto no Ministério da Saúde.

Qual é então a importância do VDP? Além de permitir uniformizar a descrição e a compreensão do problema entre os atores interessados em sua solução, o VDP é fundamental para o monitoramento do problema. Para tanto, é preciso definir as fontes de verificação e os indicadores de avaliação de cada descritor.

Em nosso exemplo, as fontes de verificação para os três descritores podem ser denúncias de consumidores e/ou resultados de análises de controle de qualidade. Um indicador para o primeiro descritor poderia ser o percentual de amostras adulteradas do medicamento " $X$ ":

$\mathrm{n}$ e de unidades do medicamento " $\mathrm{X}$ " sem o princípio ativo indicado na fórmula $\times 100$

$\mathrm{n}$ e de unidades do medicamento " $\mathrm{X}$ " examinadas 
Com base na descrição do problema, passa-se à explicação do mesmo, desde as causas mais imediatas dos descritores - os fluxos de produção ou fatos, gerados, por sua vez, por causas intermediárias (acumulações ou capacidades de produção) - até as causas mais determinantes ou, poderíamos dizer, "finais" do problema, as regras.

O processo de explicação situacional de um problema tece, pouco a pouco, uma espécie de rede ou teia de causas, entrelaçadas, cada causa sendo um ponto, ou nó, desta rede. As causas são chamadas de nós explicativos. Existe um mútuo condicionamento entre causas de diferentes planos, bem como entre as internas a cada plano.

O método PES também propõe que o ator que explica distingüa, entre as causas do problema, as que controla das que não controla. As primeiras situam-se dentro do espaço de governabilidade do ator; as segundas estão fora da governabilidade e se localizam no que se chama espaço fronteira do problema. Esta distinção é importante pois antecipa, já no momento explicativo, uma análise preliminar da viabilidade de intervenção no problema.

O PES também propõe distinguir, entre as causas do problema, aquelas apenas indiretamente ligadas ao mesmo, mas que fazem parte de outros problemas; elas, assim como as conseqüências do problema, situam-se no espaço fora do problema.

A fim de facilitar a sistematização da explicação situacional, e de possibilitar uma visão de conjunto, sintética, da rede de causalidade, o Método PES propõe o desenho de um Fluxograma Situacional. Para o problema da fraude e da falsificação de medicamentos, uma parte do fluxograma teria o desenho mostrado na Figura 4.

As causas em cinza-claro se situam dentro do espaço de governabilidade do ator, o Secretário Estadual de Saúde; já as causas em branco, fogem a seu controle, situando-se no espaço fronteira do problema.

O próximo passo do momento explicativo é a identificação dos nós críticos, das causas mais importantes do problema, que são, por isso, objeto do plano. Para a identificação dos nós críticos se devem levar em consideração os seguintes critérios:

- a causa deve ter alto impacto sobre o VDP, isto é, se a causa for eliminada, haverá uma mudança importante em um ou mais descritores do problema, no sentido da solução do mesmo.

- a causa deve ser um centro prático de ação, isto é, deve ser possível intervir, concretamente, sobre a mesma. Muitas vezes identificamos causas sobre as quais não se pode intervir diretamente, embora sejam importantes. Nesses casos, acaba sendo necessário intervir numa causa anterior. Em nosso exemplo, a causa em nossa sociedade, a saúde é um produto comercial e muito rentável, não é um centro prático de ação mas nós explicativos

espaço de governabilidade do ator

espaço fronteira do problema

nós críticos 
Figura 4 Fluxograma situacional (parcial)

Regras

R1 = Parte das farmácias escolhem distribuidores segundo, apenas, o critério do preço (lógica do lucro), sem levar em conta a qualidade.

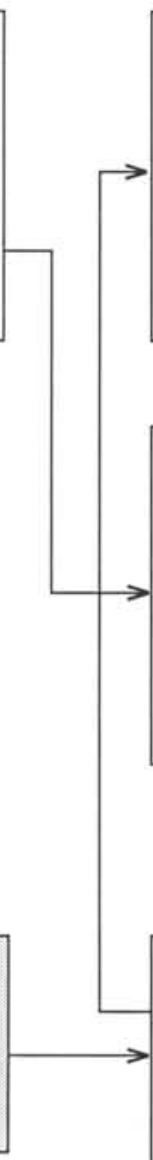

Acumulações

Fluxos

$A 2=A$ maioria das farmácias e drogarias não dispõe de farmacêuticos responsáveis durante seu horário de funcionamento.

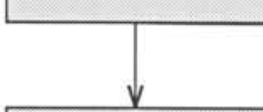

$A 3=$ Grande parte das farmácias e drogarias não possui rotina de verificação e controle da condições dos medicamentos que recebe.
VDP

$D 1=$ Lotes de n

_ do medicamento

$X$, não contêm o principio ativo constante de sua fórmula.
R2 = As atividades de Vigilância Sanitária nunca foram prioridade.
A5 = As condiçōes materiais e de recursos humanos da Vigilância Sanitária Estadual são precárias.

R4 = Em nossa sociedade, a saúde é um produto comercial, e muito rentável. tos populares a preços inferiores aos do mercado, sem controle sobre a procedência, as condiçōes de armazenagem e o transporte dos mesmos. 
uma ideologia dominante na sociedade, na qual a saúde é vista como mercadoria. Não é um centro prático de ação porque não é possível intervir diretamente, isto é, realizar uma operação, sobre uma ideologia; para mudar uma ideologia seria necessário intervir em regras, acumulações e fluxos que a produzem, ou a reforçam.

- a causa deve ser um centro oportuno de ação política, isto é, deve ser politicamente oportuno atuar sobre a mesma durante o período do plano. Aqui também cabe uma avaliação preliminar da viabilidade política e da relação custo-benefício político da intervenção sobre o problema.

O próximo passo é descrever os nós críticos que não tenham um enunciado muito preciso. Isto é fundamental para se ter clareza, ou precisão, sobre onde intervir. Cada nó crítico, assim como as demais causas, é um subproblema do problema. É preciso, portanto, construir o Vetor de Descrição do Nó Crítico (VDNC).

Em nosso exemplo, um nó crítico pode ser as condições materiais e de recursos humanos da Vigilância Sanitária Estadual são precárias. Ora, se nos limitarmos apenas a esta informação, será muito difícil definir como agir para solucionar este problema. As condições são precárias porque o espaço, os equipamentos e os recursos humanos são insuficientes em quantidade? Ou a precariedade é qualitativa? Ou ambas? Há alguma área da Vigilância mais prejudicada que outra, ou a precariedade é geral? A pergunta que devemos fazer é: Como se manifesta a precariedade das condições materiais e de recursos humanos da Vigilância Sanitária? Quais fatos ou sintomas a caracterizam?

Em nosso exemplo, o nó crítico selecionado poderia ter o seguinte VDNC:

1) Apenas 30\% das viaturas existentes para o trabalho de fiscalização sanitária encontram-se em condições de circulação, e metade seive a outros setores da Secretaria de Saúde;

2) Existem apenas dois computadores em toda a Vigilância Sanitária, ambos com capacidade de processamento e armazenamento muito pequenas e sem ligação à Internet;

3) $70 \%$ funcionários da Vigilância não têm o 2 grau completo;

4) $50 \%$ dos funcionários da Vigilância Sanitária só têm treinamento na área de alimentos e há oito anos não recebem qualquer atualização ou reciclagem;

5) Há um déficit de dez profissionais de nivel superior, e não existe um só farmacêutico na Vigilância Sanitária Estadual.

Além de facilitar a definição do que fazer, isto é, da operação lou das operações) a se realizar sobre o nó crítico, o VDNC também tem as funções de permitir o monitoramento do problema e de avaliar a eficácia das intervenções.
Vetor de Descrição do Nó Crítico 


\section{Momento normativo}

Um ator pode desenhar e escolher seus planos, mas não pode escolher as circunstâncias, ou o contexto, em que estes planos serão realizados. Estas circunstâncias, que chamaremos de $\beta$, compreendem as ações dos outros atores, as variáveis relevantes para os problemas que nenhum dos atores envolvidos controla, e as surpresas.

Assim, entre o desenho de nossos planos e os resultados na realidade, há uma série de mediações ou condicionantes. De um lado, as circunstâncias $\beta$, acima referidas, de outro, o que chamaremos de condições $\alpha$ : a qualidade do plano (consistência, confiabilidade, etc.) e a qualidade da gerência (conhecimentos, habilidades, experiências e perfil do gestor e sua equipe, tecnologias gerenciais disponíveis, etc); enquanto $\beta$ refere-se à governabilidade do ator sobre a situação, $\alpha$ representa sua capacidade de governo (Figura 5).

Figura 5 Condicionantes dos resultados de um plano

Vetores de Descrição de Nós Críticos Alterados (VDNC*)

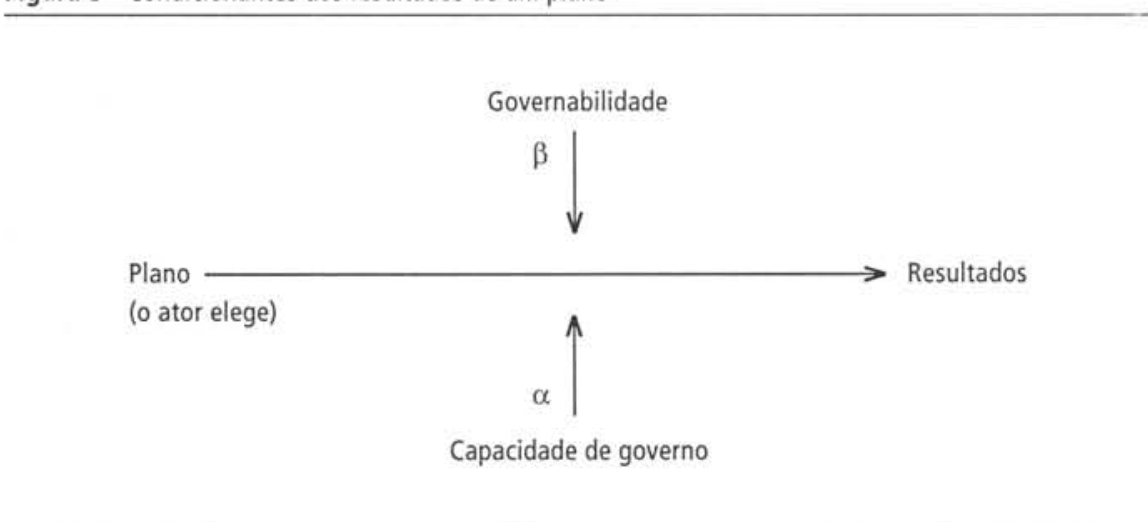

Capacidade de governo

Não se pode ter certeza sobre o alcance dos resultados de um plano; para o enfoque estratégico, o plano é uma aposta sobre o futuro. Mas não uma aposta cega, pois se apóia num cálculo interativo (que leva em conta os outros atores) e probabilístico ou condicional (elabo. ram-se planos alternativos, para diferentes cenários).

O plano é um conjunto coerente e consistente de operações desenhadas para alterar os nós críticos dos problemas. Espera-se que as operações transformem os fatos, ou fenômenos, que compõem a descrição dos nós críticos, e formem Vetores de Descrição de Nós Críticos alterados (que chamaremos VDNC*). Estes, por sua vez, deverão alterar o Vetor de Descrição do Problema (VDP) a que pertencem, transforman- 
do-o em um Vetor de Descrição de Resultados (VDR). Os VDNC** e o VDR compõem a Situação-Objetivo (SO), isto é, expressam o grau de mudança esperado com relação a um problema, em se considerando determinado cenário.

Assim, o ponto de partida para a elaboração do plano é o desenho preliminar da Situação-Objetivo e das operações, consideradas potentes e necessárias, para alterar os descritores de cada nó crítico dos problemas selecionados.

Uma operação é um ato de intervenção sobre um ou vários nós críticos, e um único nó crítico pode exigir mais de uma operação. Trata-se de um desenho preliminar porque, sem a explicitação do cenário, ou do contexto, em que se espera pôr o plano em prática, é muito difícil precisar os resultados das operações. Neste primeiro momento, se devem definir as operações necessárias para alterar os nós críticos dos problemas, no sentido dos resultados desejados, e examinar o balanço de efeitos de cada operação sobre o conjunto dos nós críticos. Esta análise se faz através da Matriz Nós Críticos-Operações (Quadro 1).

Quadro 1 Matriz Nós Criticos - Operações

\begin{tabular}{lcccc}
\hline $\begin{array}{l}\text { Nós } \\
\text { críticos }\end{array}$ & $\begin{array}{l}\text { Operações } \\
\text { OP1 }\end{array}$ & OP2 & OP3 & DOP4 \\
NC1 & + A & 0 & + A & + A \\
NC2 & 0 & $+A$ & 0 & $-B$ \\
NC3 & 0 & 0 & $+A$ & 0 \\
NC4 & $-B$ & 0 & 0 & + A \\
\hline
\end{tabular}

A matriz apresenta, na primeira coluna, quatro nós críticos de um problema e, nas demais, as operações desenhadas para enfrentá-los. As células da tabela estão preenchidas com o impacto - positivo $(+)$, negativo $(-)$ ou nulo $(0)$ - que se julga que as operações terão sobre cada nó, além da intensidade do impacto - alto (A) ou baixo (B).

A Operação 1, por exemplo, tem um impacto positivo e alto sobre o nó crítico para o qual foi desenhada (NC1), nenhum impacto sobre os nós críticos 2 e 3 e um impacto negativo, porém baixo, sobre o nó crítico 4. O balanço dos efeitos desta operação sobre o conjunto dos nós críticos ainda é positivo. Assim, pode o gestor tomar a decisão de realizála, e de desprezar seus efeitos negativos sobre o NC4, pois este último
Vetor de Descrição

de Resultados

Situação-Objetivo 
nó deverá ser alterado por meio de uma operação específica (DOP4). Esta operação teria um impacto positivo e alto, sobre o mesmo, e compensaria os possíveis efeitos negativos da OP1. Esta análise não é matemática, mas um juízo situacional, cuja sistematização numa matriz fornece uma visão global e preliminar da potência e da coerência do plano.

O exemplo acima também contém outro elemento importante para um plano estratégico-situacional: as demandas de operações. Uma demanda de operação é uma operação de intervenção sobre um nó crítico fora de controle (governabilidade) do ator que assume o plano. Por isso, este ator deverá demandá-la ao ator que controla as variáveis intervenientes no nó crítico em questão, ou os recursos necessários para enfrentar esse nó. O ator demandado poderá realizar, ou não, a operação, conforme sua posição sobre o problema e sobre o ator demandante; a busca de seu apoio deverá ser tratada no momento estratégico.

Para a área de saúde, a idéia de se trabalhar com um plano que, além de operaçōes, contenha demandas de operações facilita um enfrentamento mais integral dos problemas, e permite a realização de operaçōes intersetoriais.

Características e requisitos de uma operação:

- uma operação é um compromisso de ação do ator que a enuncia. E deve ser sempre enunciada, claramente, por meio de um verbo no infinitivo (fazer, realizar, construir, etc.). Subentende-se: "Eu me comprometo a fazer tal coisa...". Uma operação se distingue de uma mera intenção.

- uma operação é uma relação entre recursos, produtos e resultados, isto é, combina e utiliza uma variedade de recursos escassos (poder, recursos econômicos, capacidades organizativas, conhecimentos, etc.) para gerar produtos que, por sua vez, provocarão um resultado (impacto esperado nos VDNC e no VDP).

Assim, o desenho de uma operação deve obedecer aos seguintes requisitos:

- definir claramente responsáveis pela realização da operação e, quando pertinente, os destinatários ou beneficiários da mesma.

- distinguir claramente os meios concretos para alcançar os objetivos (quais recursos serão usados, em que quantidades ou proporções em que momentos, etc.).

- definir claramente os produtos a serem gerados e os resultados que se espera alcançar com os mesmos.

- estabelecer um horizonte de tempo para o alcance dos resultados.

Os resultados não são uma decorrência automática dos produtos gerados por uma operação. Imaginemos que, para resolver o problema 
da baixa qualidade do atendimento prestado pelos profissionais de um hospital, são desenhadas duas operações - OP1: capacitar X profissionais ao ano durante dois anos; e OP2: reequipar os setores de internação $e$ apoio diagnóstico e terapêutico em $100 \%$ de suas necessidades ao longo de dois anos; os produtos obtidos (2X profissionais capacitados e $100 \%$ das necessidades de equipamentos dos setores de internação e apoio diagnóstico e terapêutico atendidas em dois anos) podem não resultar em melhoria da qualidade do atendimento prestado pelos profissionais do hospital, ou podem representar apenas uma pequena melhoria, pois outras variáveis podem estar condicionando os resultados.

Outro requisito importante é a definição de responsáveis pelas operações, um instrumento essencial para uma gestão voltada para resultados.

Definidas, as operações devem ser desagregadas em ações, detalhando-se a forma como serão implementadas, os recursos necessários, os produtos gerados e os responsáveis pelas mesmas.

No entanto, não há plano no vazio. Todo plano se realizará (ou não) em determinado contexto ou cenário. O cenário expressa o comportamento de variáveis fora do controle do ator, mas de impacto importante, positivo ou negativo, sobre o plano.

O PES propõe que se trabalhe com planos alternativos, considerando-se três cenários - um otimista, ou de teto, um central e um pessimista, ou de piso. A lógica é a seguinte: se ocorrem as circunstâncias X, meu plano é Y, com um resultado provável $Z$; se ocorrem as circunstâncias $\mathrm{A}$, meu plano é $\mathrm{B}$, com um resultado provável $\mathrm{C}$.

O cenário expressa um relato que deve ser possível (não pode ser puro produto da imaginação, ou de voluntarismo) e plausível (as partes componentes do relato devem ser coerentes entre si).

Para a formulação de cenários, o PES propõe o seguinte:

1) Identificação de variantes simples: seleção das variáveis mais importantes, fora de controle do ator, cujo comportamento pode interferir, significativamente, na possibilidade de implementação do plano e em seus resultados.

2) Simulação de comportamentos possíveis das variantes simples, combinando-os em três hipóteses (variantes combinadas):

- cenário otimista (ou de teto): diante das circunstâncias, e considerando-se as tendências que se apresentam, representa o melhor comportamento que se pode esperar das variantes.

- cenário central: representa um comportamento mediano.

- cenário pessimista (ou de piso): representa o pior comportamento a se esperar das variantes, dadas as circunstâncias e tendências que se apresentam.

3) Identificação do cenário mais provável de realização do plano. cenário 
Em nosso exemplo sobre o problema de fraude e da falsificação de medicamentos, e considerando que um plano para solucionar esse problema envolveria operações de fortalecimento da estrutura estadual de Vigilância Sanitária, revisão da legislação sobre as condições de produção, distribuição e comercialização de medicamentos e ampliação do poder da Vigilância Sanitária nos casos de crimes contra a saúde pública, o ator, Secretário Estadual de Saúde, poderia considerar as seguintes variantes simples:

- orçamento para a área de saúde no Estado durante o período de implementação do plano (considerando todas as fontes de recursos);

- posição da Assembléia Legislativa do Estado;

- posição da mídia;

- comportamento dos produtores; e

- comportamento/adesão da população.

Para estas variantes, três cenários possíveis seriam:

1) Cenário otimista: o orçamento para a área da saúde no Estado tem um aumento em torno de $30 \%$, em virtude do aumento da arrecadação estadual, da negociação bem sucedida de convênios com o nível federal e de parcerias com a iniciativa privada. A Assembléia Legislativa aprova $2 / 3$ das mudanças propostas pelo Executivo na legislação sanitária do Estado. A mídia dá ampla cobertura à fraude e à falsificação de medicamentos e apóia as ações da Vigilância. Os grandes produtores de medicamentos, no interesse de resguardar a imagem de seus produtos, colaboram com as ações da Vigilância Sanitária, e denunciam fraudes. Mas resistem quanto a mudanças na legislação sanitária que impliquem maior controle do poder público sobre a produção. A população está sensibilizada e atenta, e adota as medidas de controle que a Vigilância Sanitâria e a mídia estimulam.

2) Cenário central: o orçamento para a área da saúde no Estado cresce apenas $5 \%$ em relação ao orçamento executado no ano anterior, e ainda há riscos de contingenciamentos ao longo do ano. Isso irá impor critérios mais rigorosos de definição de prioridades para a distribuição dos recursos entre as diversas ações da Secretaria de Saúde. A Assembléia Legislativa aprova 2/3 das mudanças propostas, pelo Executivo, para a legislação sanitária do Estado. A mídia dá ampla cobertura ao tema, mas explora, principalmente, as denúncias de fraudes e falsificações, e não garante espaço significativo para as ações e orientações da Vigilância, nem para a continuidade do tema nas pautas dos noticiários. Os grandes produtores de medicamentos se mantêm, em sua maioria, indiferentes à campanha contra as fraudes e falsificações e continuam resistentes a alterações na legislação. A população está sensibilizada, mas ainda encontra muitas dificuldades para aplicar as medidas de controle sugeridas pela Vigilância.

3) Cenário pessimista: o orçamento para a área da saúde no Estado corresponde a apenas $90 \%$ do orçamento executado no ano anterior e ainda 
há riscos de contingenciamentos, em função da necessidade de pagamento de serviços da divida externa do Estado. A Assembléia Legislativa aprova apenas as mudanças na legislação sanitária que não alteram a responsabilização penal, de produtores, distribuidores e comerciantes, sobre atos de fraude e falsificação de medicamentos, nem ampliam a capacidade de controle do poder público sobre os produtores. A mídia dá ampla cobertura ao tema, mas explora, principalmente, as denúncias de fraudes e falsificações. E não garante espaço significativo para as ações $e$ orientações da Vigilância nem para a continuidade do tema nas pautas dos noticiários. Os grandes produtores de medicamentos pressionam a mídia a não dar muito espaço para o tema e fazem lobby, junto aos deputados, para não aprovarem a maior parte das mudanças na legislação propostas pelo Executivo. A população se sensibiliza com o problema mas está muito descrente da capacidade de intervenção do poder público e não adere à campanha.

Como se pode observar, o comportamento isolado de algumas variantes não muda, necessariamente, de um cenário para outro. A diferença entre cenários se faz na combinação de comportamentos das variantes.

$\mathrm{Na}$ dependência do cenário, as operações poderão ser total ou parcialmente realizadas, em mais ou menos tempo ou, ainda, não serem realizadas. Algumas operações serão necessárias apenas em determinado cenário; outras são insensiveis a mudanças de variantes, e se podem dar em qualquer cenário. Assim, trabalhar com três cenários não significa ter, necessariamente, três planos totalmente distintos.

Trabalhar com cenários não só ajuda a reduzir a incerteza, mas é fundamental para se avaliar a execução do plano; atingir $70 \%$ das metas programadas, num cenário otimista, não é a mesma coisa que atingir os mesmos $70 \%$ num cenário pessimista. O segundo resultado mostra um desempenho muito melhor que o primeiro.

O PES propõe, ainda, outras medidas para se lidar melhor com a incerteza:

1) Não congelar nunca os cálculos sobre o futuro: um plano deverá estar sempre sendo refeito, atualizado;

2) Utilizar plenamente todos os quatro recursos de cálculo (predição, previsão, reação veloz frente a mudanças imprevistas e aprendizagem com o passado recente);

3) Elaborar planos de contingência para fazer face às surpresas.

Uma surpresa é um evento de muito baixa probabilidade de ocorrência mas de alto impacto sobre o plano. As surpresas não surpreendem por serem inimagináveis, mas porque não se sabe quando ocorrerão e por não se poder predizer sua intensidade. Há surpresas inimagináveis, mas a grande maioria é imaginável - como acidentes, catástro- surpresa 
planos de contingência

viabilidade fes, a renúncia de um Presidente, e outras, identificáveis com base na análise de confiabilidade do plano. Todo plano, baseia-se em um conjunto de pressupostos ("realizarei a operação 1 e obterei o resultado X, junto ao ator $\mathrm{B}$, num cenário $\mathrm{Y}^{\prime \prime}$ ). Os pressupostos serão mais ou menos débeis conforme resistam à prova de confiabilidade, que se inicia com o raciocínio "... a menos que ...", enumerando-se então uma circunstância de invalidação dos resultados da aposta. Assim, "realizarei a OP1 e obterei o resultado $\mathrm{X} \ldots$ a menos que o ator $\mathrm{B}$ mude radicalmente de idéia", etc. As circunstâncias de invalidação de muito baixa probabilidade de ocorrência, mas de alto impacto sobre o plano, constituem surpresas a serem tratadas com planos de contingência.

No entanto, elaborar planos de contingência para todas as surpresas imagináveis é antieconômico e improdutivo! Assim, recomenda-se a elaboração de planos de contingência apenas para as surpresas de: 1) alta probabilidade, alto impacto e qualquer custo (de elaboração e de implementação) do plano de contingência; 2) baixa probabilidade e baixo custo, mas de alto impacto sobre os resultados do plano.

Cabe ainda uma observação geral sobre o caráter do plano, segundo o enfoque de planejamento estratégico-situacional. O plano é seletivo e se concentra em poucos problemas, quase-estruturados e estratégicos para o ator/gestor. Os problemas rotineiros e normatizáveis podem ser resolvidos por normas técnicas pré-definidas, através da programação.

\section{Momento estratégico}

Duas perguntas são centrais neste momento: 1) Que operações do plano são viáveis hoje? 2) Como posso construir viabilidade para as operações inviáveis durante meu período de governo/gestão?

A estratégia consiste em buscar uma maneira de construir a viabilidade de um plano (torná-lo possível). Há quatro tipos puros de estratégia, que se combinam, ou apresentam variações, na prática:

1) Estratégia de autoridade/imposição (ordens, diretivas, possíveis a partir de uma determinada posição de poder que um ator ocupe, subordinando outros).

2) Estratégia de cooperação (persuasão, sedução, negociação cooperativa - todos saem ganhando - acordos, criação de possibilidades de consenso e de instâncias de prevenção de conflitos, etc.). Neste tipo de estratégia há o domínio da lógica do "eu e o outro"; minhas opções e jogadas devem mostrar ao outro possibilidades de benefícios mútuos. A condição de êxito deste tipo de estratégia é a confiança.

3) Estratégia de confrontação (oposição, negociação conflitiva - só um lado ganha - arbitragem, julgamento perante tribunais, medição 
política de forças com o outro). Aqui domina a lógica do "eu e meu oponente"; minhas opções e jogadas devem restringir as possibilidades do outro. A condição de êxito deste tipo de estratégia é a força, e predomina a desconfiança.

4) Estratégia de enfrentamento violento (guerrilha, guerra ou dissuasão armada, etc.). Neste tipo de estratégia há o domínio da lógica do "amigo-inimigo"; minhas opçōes e jogadas devem anular as possibilidades do outro. A condição de êxito é a maior capacidade de violência, e predomina a animosidade.

Essas quatro estratégias respondem a um mesmo princípio teórico: a interação entre atores fortes. Sem força, sequer se pensa em cooperação, pois nenhum ator valoriza a cooperação com outro que não tem força.

O termo estratégia se originou na guerra, no vocabulário militar, mas hoje tem muitas aplicações e significados. Para o PES, "estratégico" é o que é importante fazer para alcançar um objetivo futuro, transcendente, e também o modo de lidar ou cooperar com o outro em um jogo, para vencer sua resistência ou ganhar sua colaboração.

Todo plano tem projetos (conjuntos de operações) que podem ser políticos, econômicos, cognitivos e organizativos, e é preciso saber se são política, econômica, cognitiva e organizativamente viáveis. Um projeto político, por exemplo, pode ser economicamente inviável, um projeto econômico, pode ser econômica e politicamente inviável, etc. Assim, é necessário considerar vários tipos de viabilidade, na análise estratégica: viabilidade política, econômica, organizativa e cognitiva.

Além disso, a estratégia compreende não apenas a capacidade de decidir, mas também a de fazer e a de garantir a manutenção do que foi feito. Por isso, a análise de viabilidade deve considerar também a viabilidade de decisão, de operação (ou materialização) e de reprodução (ou manutenção). Uma ilustração destes conceitos é a aprovação, na reforma da Constituição em 1988, dos avanços contidos no tema Saúde. A correlação de forças entre os atores, naquele momento, permitiu a votação a favor das propostas mais progressistas (houve viabilidade de decisão). Mas os problemas que o SUS enfrenta, até hoje, de implantação e aperfeiçoamento, refletem as dificuldades de viabilidade de materialização e de manutenção.

A análise de viabilidade começa pela análise dos atores relevantes, a fim de se procurar saber, em primeiro lugar, qual sua motivação ante as operações do plano e, em segundo lugar, qual sua força ou capacidade de facilitar ou dificultar/impedir a realização das mesmas.

A motivação de um ator é uma combinação do se' 1 interesse lou posição) por uma operação com o valor (ou importância) que ele atribui à mesma. 
operaçōes conflitivas operações de consenso
O interesse se expressa em termos de apoio $(+)$ à operação, rejeição (-) ou indiferença (0). O valor, ou importância, que um ator atribui ao plano, e às operações em jogo, pode ser classificado como alto (A), médio (M) ou baixo (B).

Assim, um ator pode ter uma posição ou interesse favorável a uma operação, e pode apoiá-la (+). Mas a intensidade deste apoio não será muito forte se a importância, ou o valor, que ele atribui à operação for baixo (B); sua motivação, então, com relação a esta operação será representada por $(+B)$, sinal de um pequeno apoio. Do mesmo modo, a rejeição, ou o rechaço, a uma operação $(-)$ poderá ter diferentes intensidades (A, M ou B), conforme o valor ou a importância da operação para o ator.

A análise da motivação dos atores frente às operações fornece uma avaliação das possibilidades de alianças e conflitos entre os atores. E uma estimativa da disposição, ou da intensidade com que cada um se mobilizará, ou se motivará, para possibilitar ou impedir a operação. Sistematiza-se esta análise através de uma matriz, onde se relacionam, para cada operação, a motivação de cada ator (Quadro 2).

Quadro 2 Matriz de motivação dos atores

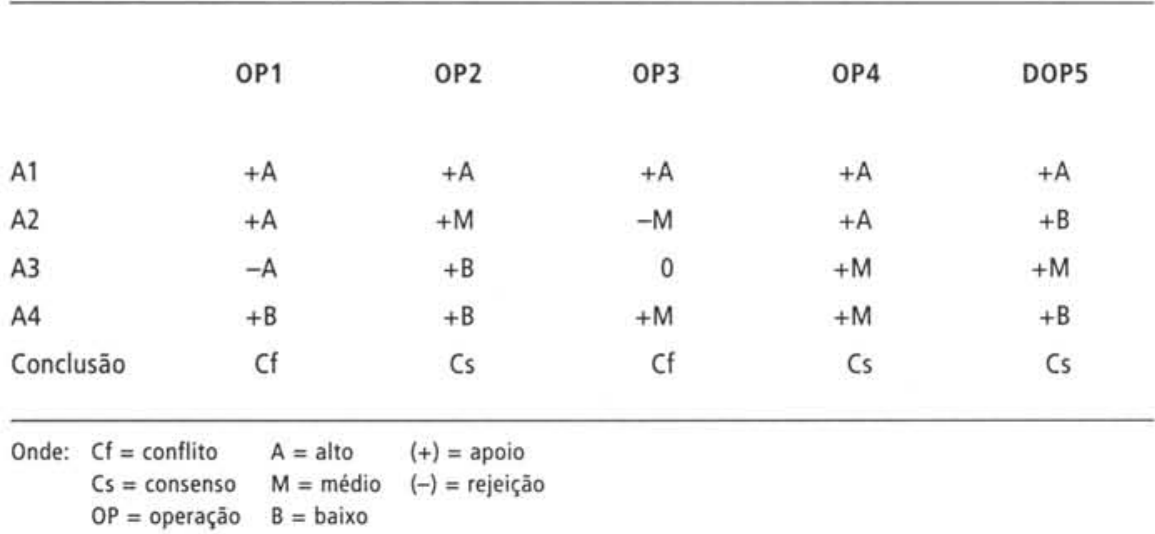

A matriz de motivação indica as operações conflitivas e as de consenso, na situação inicial. No exemplo acima, as operações 1 e 3 são conflitivas. Basta uma única rejeição $(-)$, independentemente de sua intensidade, para a operação ser considerada conflitiva.

No entanto, operação conflitiva não é sinônimo, necessariamente, de operação inviável, pois depende da capacidade (poder/força) do ator contrário à mesma de impedir, ou dificultar, sua realização. Assim, é preciso avaliar, além da motivação dos atores, a força, ou o peso, dos mesmos. 
A análise do peso de um ator é a precisão do grau de controle (direto e indireto) que ele tem sobre o conjunto de recursos críticos necessários para realizar as operações do plano. Este conjunto de recursos críticos inclui todas as capacidades (recursos) requeridas para tomar-se a decisão sobre a realização das operações (recursos de decisão), e as capacidades necessárias para implementar as operações e reproduzi-las estavelmente (recursos de materialização e reprodução).

No exemplo sobre o problema de fraude e falsificação de medicamentos, para fazer face às operações de fortalecimento da estrutura estadual de Vigilância Sanitária; de revisão da legislação sobre as condições de produção, distribuição e comercialização de medicamentos; e de ampliação do poder da Vigilância nos casos de crimes contra a Saúde Pública, seriam necessários, entre outros, os seguintes recursos:

-X1: capacidade de decisão do Secretário Estadual de Saúde

-X2: recursos financeiros

-X3: controle sobre a Assembléia Legislativa

-X4: conhecimentos jurídicos, particularmente sobre Direito Sanitário

- X5: conhecimentos técnicos especializados sobre o processo de produção de medicamentos

-X6: capacidade de decisão e ação da polícia

- X7: capacidade de decisão do Poder Judiciário

- X8: capacidade de mobilização da sociedade civil

Tais recursos estão sob controle de diversos atores, em graus diferentes. O grau de controle é um indicador da força do ator (de sua capacidade de produzir fatos que viabilizem, ou inviabilizem, operações) e se expressa como seu vetor de peso; na aplicação do PES, é costume percentuais representarem, aproximadamente, esse controle.

O Vetor de Peso de um ator inclui tanto seu grau de controle direto sobre os recursos críticos, como o controle indireto sobre os mesmos (resultante das adesões de outros atores), além da adesão da população não-organizada, ao ator. Em nosso exemplo, o ator Secretário Estadual de Saúde controla, diretamente, o recurso X1 em $100 \%$, além de X2, X4 e X5; nestes últimos casos, os percentuais podem variar, pois outros atores também podem ter controle direto sobre tais recursos. O Secretário não tem controle direto sobre os recursos X3, X6, X7 e X8, mas os pode controlar indiretamente, conforme a adesão, a ele, dos atores que controlam, diretamente, tais recursos, respectivamente, lideranças do partido político majoritário na Assembléia, Secretário de Segurança do Estado, Presidente do Tribunal de Justiça e entidades representativas da sociedade civil. Além disso, o Secretário ainda pode ter o apoio da população (adesão da população não organizada), recurso fundamental para as ações de Vigilância. 
A análise de viabilidade se conclui através de uma matriz onde, para cada operação considerada conflitiva, listam-se os recursos necessários, os atores que a apoiam, ou rejeitam, e o grau de controle dos mesmos sobre os recursos críticos para aquela operação. No exemplo do Quadro 3, a análise de motivação considerou conflitiva a OP1.

Quadro 3 Análise de viabilidade da Operação 1 (OP1)

Atores favoráveis

$\begin{array}{ccc}\text { A1 } & \text { A2 } & \text { A4 } \\ 100 \% & 0 & 0 \\ 60 \% & 10 \% & 0 \\ 0 & 0 & 20 \% \\ 30 \% & 40 \% & 0\end{array}$

Controle de recursos

$\begin{array}{cccc}100 \% & \mathrm{X} 1 & 0 & \mathrm{A3} \\ 70 \% & \mathrm{X} 2 & 30 \% & 0 \\ 20 \% & \mathrm{X} 3 & 80 \% & 30 \% \\ 70 \% & \mathrm{X} 4 & 30 \% & 80 \% \\ & & & 30 \%\end{array}$

Onde: $\mathrm{X}=$ recurso $\mathrm{A}=$ ator

A matriz do Quadro 3 sintetiza a análise de motivação e o vetor de peso dos atores, com relação à OP1. A conclusão não resulta de uma análise puramente matemática, os percentuais são apenas um artifício de aproximação a questões complexas, como a força de um ator. A análise deve ser qualitativa e a natureza dos recursos é um dos elementos a se considerar. No caso descrito, estamos supondo ser o recurso X3 - único sob controle do ator contrário, em sua maior parte - essencial para a materialização da operação.

A construção de viabilidade para as operações consideradas inviáveis, na situação inicial, se dá através do desenho de uma estratégia, para a qual se devem considerar os seguintes elementos:

- a possibilidade de utilizar operações viáveis para construir viabilidade ("abrir caminho") para as operações inviáveis;

- com quais atores será preciso lidar;

- que meios táticos e estratégicos será necessário utilizar; e

- em que seqüência e tempos.

Na montagem da estratégia, combinam-se dois tipos de operações: as operações "OP" - que têm a capacidade de influir diretamente sobre os nós críticos dos problemas - e as operações " $K$ " $(O K)$, cuja função é facilitar a realização das primeiras. As operações " $K$ " não têm sentido, isoladamente, a não ser quando estão a serviço de alguma operação OP. 
Em geral não podem ser desenhadas previamente, pois respondem a necessidades e situações muito imediatas, do dia-a-dia da gestão.

Uma metáfora "farmacêutica", apresentada por Matus, pode ajudar no entendimento do conceito de operações " $\mathrm{K}$ ". Um remédio amargo (OP) não poderia cumprir sua função de atacar as causas de uma doença se não viesse envolto por uma substância doce (OK). Assim, algumas operações " $\mathrm{K}$ ", típicas, seriam: operações de distração, de surpresa, de concessão, de reação, de mobilização popular, de comunicação, de compromisso...

Alguns conjuntos de operações " $\mathrm{K}$ " cumprem funções muito especializadas no processo de criação de viabilidade, dando origem ao que se pode chamar de meios táticos. Tais meios táticos, ao serem utilizados em seqüência, na trajetória estratégica, dão origem aos meios estratégicos. Assim, meios estratégicos são conjuntos de operações OK que têm demonstrado, na prática, através de seu uso repetido, uma alta eficácia para viabilizar operações OP. Os meios estratégicos mais usados são: imposição (ou uso de autoridade), persuasão, negociação, mediação, julgamento em tribunais, coação, confrontação, dissuasão e guerra.

Além de se escolher os meios estratégicos para lidar com cada ator, deve-se também definir a seqüência de realização de todas as operações e ações do plano, distribuídas no tempo, juntamente com as estratégias (ou meios estratégicos selecionados); esta seqüência conforma a trajetória estratégica do plano.

\section{Momento tático-operacional}

O principal problema no momento de execução de um plano é a defasagem entre a velocidade com que ocorrem as mudanças na situação real e a velocidade com que um ator pode alterar ou corrigir seu plano. A solução, ou a minimização, deste problema depende da capacidade de cálculo do ator, da existência de informação oportuna para subsidiar a tomada de decisão e da possibilidade de previsão da mudança situacional. Tudo isto depende, fundamentalmente, de informação.

O PES propõe, então, um Sistema de Monitoração do Plano:

- que seja específico para cada usuário e disponha de informação seletiva, diferenciando-se, portanto, de um banco de dados (que pode ser usado por vários tipos de usuários, com necessidades diferentes e contém uma massa de informações diversificadas);

- em que o valor e a utilidade da informação dependem de sua recepção em tempo eficaz, ou mesmo, em alguns casos, em tempo real; o tempo máximo de atraso, admissível, entre o fato e a recepção da informação será definido pelo lapso eficaz em que a correção de uma ação é possível;
Sistema de Monitoração do Plano 
- em que a monitoração dar-se-á mediante fluxos de informação laterais, descentralizados e rápidos, onde todos os níveis da organização são produtores e usuários de informação;

- em que se utilizarão a monitoração visual e direta, e também a monitoração sofisticada, através de sinais de atenção e alarme, a serem disparados toda vez que os indicadores monitorados saírem da faixa de normalidade definida;

Os principais elementos a monitorar são:

- descritores e nós críticos dos problemas (VDNC e VDP), confrontando-os constantemente com os resultados pretendidos (VDNC* e VDR); esta monitoração visa avaliar as eficácias intermediária e terminal das operações.

- recursos, produtos, resultados, oportunidade/cronograma e execução orçamentária das operações; esta monitoração permite avaliar a eficácia e a eficiência das operações.

- atores relevantes para os problemas enfrentados; monitoração de suas motivações e de seus vetores de peso, permitindo avaliar a eficácia das estratégias utilizadas junto aos mesmos.

- contexto ou circunstâncias em que se desenvolve o plano o que permite atualizar constantemente os cenários e, consequentemente, os planos.

Um bom sistema de monitoramento é, portanto, condição essencial para a execução de um plano com alguma probabilidade de eficácia. Outra condição, igualmente importante, é saber usar o tempo, seletivamente, nos problemas de alto valor estratégico e nas operações que marcam o rumo das mudanças situacionais pretendidas. Este é um dos maiores desafios de todos que ocupam posições de gestores. Suas agendas, em geral, estão tomadas por urgências (porque eles não têm um bom sistema de planejamento e monitoramento, e, assim, não conseguem antecipar-se aos problemas) e de problemas que poderiam ser resolvidos rotineiramente (normatizadamente) por níveis descentralizados da organização. Em vista dessa situação, o PES propõe, entre outros, três importantes sistemas de direção estratégica:

- Sistema de Agenda do Dirigente, através do qual se controlam o tempo e o foco de atenção do dirigente, evitando-se sua dispersão.

- Sistema de Gerência por Operações, com a definição, no plano, de responsáveis pelas operações e ações.

- Sistema de Petição e Prestação de Contas, através de cobrança e de prestação de contas, sistematicamente, por desempenho.

Estes sistemas são interdependentes e as características que assumem, em uma organização, permitem classificá-la segundo seu grau de responsabilidade (Quadro 4). 
Quadro 4 Caracteristicas de sistemas de gestão, segundo o tipo de organização

\begin{tabular}{|c|c|c|c|}
\hline \multirow{2}{*}{$\begin{array}{l}\text { Tipo de } \\
\text { organização }\end{array}$} & \multicolumn{3}{|c|}{ Sistemas } \\
\hline & Agenda do dirigente & $\begin{array}{l}\text { Petição e prestação } \\
\text { de contas }\end{array}$ & $\begin{array}{l}\text { Gerência por } \\
\text { operaçōes }\end{array}$ \\
\hline $\begin{array}{l}\text { Baixa } \\
\text { responsabilidade }\end{array}$ & $\begin{array}{l}\text { Dominio das urgências } \\
\text { e improvisaçōes }\end{array}$ & $\begin{array}{l}\text { Não há cobrança nem } \\
\text { prestação de contas }\end{array}$ & $\begin{array}{l}\text { Dominio } \\
\text { da rotina }\end{array}$ \\
\hline $\begin{array}{l}\text { Alta } \\
\text { responsabilidade }\end{array}$ & $\begin{array}{l}\text { Dominio das importân- } \\
\text { cias e do planejamento }\end{array}$ & $\begin{array}{l}\text { Cobrança e prestação } \\
\text { de contas sistemáticas, } \\
\text { por desempenho }\end{array}$ & $\begin{array}{l}\text { Dominio da } \\
\text { criatividade }\end{array}$ \\
\hline
\end{tabular}

Para concluir, cabe ressaltar que a aplicação do PES, em uma organização, não se pode restringir a uma mera aplicação de técnicas e passos da metodologia, mas pressupōe uma transformação progressiva na cultura, nas mentalidades e na forma de funcionamento da organização. Somente em organizações de alta responsabilidade pode haver demanda de planejamento.

\section{Referências bibliográficas}

ARTMANN, E., AZEVEDO, C.S.; SÁ, M.C., 1997. Possibilidades de aplicação do enfoque es. tratégico de planejamento no nivel local de saúde: análise comparada de duas experiên. cias. Rio de Janeiro: Cadernos de Saúde Pública, 13(4):723-740, out-dez.

MATUS, C., 1987. Adiós Sr. Presidente. Caracas: Pomaire Ensayos. 1993. Política, Planejamento e Governo. Brasília: IPEA.

1994 (a). El PES en la Practica. Caracas: Fundación Altadir. (mimeo)

1994 (b). Guia de Análisis Teórico. Curso de Governo e Planificação. Caracas: Fundación Altadir.

1996 (a). Estratêgias Politicas: chimpanzé, Maquiavel e Gandhi. São Paulo: FUNDAP.

1996 (b). Adeus Senhor Presidente: governantes governados. São Paulo: FUNDAP.

TESTA, M., 1995. Pensamento Estratégico e Lógica de programação: o caso da saúde. São Paulo/Rio de Janeiro: HUCITEC/ABRASCO.

SÁ, M.C.; ARTMANN, E., 1994. O Planejamento estratégico em saúde: desafios e perspectivas para o nível local. In: Planejamento e Programação Local da Vigilância da Saúde no Distrito Sanitário (MENDES, E.V.,org.), pp19-44, Brasília: OPAS. 


\section{Referências bibliográficas complementares}

BARRENECHEA, J. J.; TRUJILO URIBE, E.; CHORNY, A. H., 1990. Salud para Todos en el Año 2000: implicaciones para la planificación y administración de los sistemas de salud. Medellín: Editorial Universidad de Antioquia/OPS.

MATUS, C., 1977. Planificación de Situaciones, Caracas: Cendes/Livros Alfar. 1982. Politica y Plan. Caracas: Iveplan.

RIVERA, F.J.U.; ARTMANN, E., 1993. Esquema Operativo do Planejamento Estratégico para o Nivel Local. Revista do DAPS/ENSP.

TESTA, M., 1992. Pensar em Saúde. São Paulo: Artes Médicas.

MENDES, E.V. (org.), 1994. Planejamento e Programaçâo Local da Vigilância da Saúde no Distrito Sanitário. Brasilia. Organização Panamericana de Saúde, Série Desenvolvimento de Serviços de Saúde, ne 13.

RIVERA, F.J.U., 1989. Planejamento e Programação em Saúde: um Enfoque Estratégico. São Paulo/Rio: Cortez/ABRASCO. 


\section{Informação: da produção à utilização}

\section{Conteúdo}

Conceitos básicos e subsidiários. Sistema de informação em saúde, bancos de dados, softwares. Cadastros em Vigilância Sanitária. Base geográfica da informação.

A leitura deve permitir:

- Conhecer os conceitos básicos de dado, informação, sistema, sistema de informação, assim como a lógica de construção de um sistema de informação em saúde, capaz de servir como instrumento para a tomada de decisão e para a ação.

- Descrever, em linhas gerais, os principais Sistemas de Informação em Saúde utilizados, atualmente, no país, e identificar as informações que podem ser geradas a partir desses sistemas.

- Conhecer os softwares mais comumente empregados em Saúde Pública.

- Valorizar o espaço geográfico como possibilidade de organizar intervenções.

- Ser capaz de construir um sistema de informação sobre a produção em Vigilância Sanitária; valorizar o papel do mesmo na avaliação do desempenho dos órgãos e na construção de uma ação integrada, nos níveis locais, regionais e nacional. 



\section{Informação: da produção à utilização}

Marilia Sá Carvalho

\section{Definições}

1) Informação: ato ou efeito de informar-se, informe; dados acerca de alguém ou de algo;conhecimento, participação; comunicação ou notícia trazida ao conhecimento de uma pessoa, ou do público; instrução, direção; conhecimento amplo e bem fundamentado, resultante de análise e combinação de vários informes; coleção de fatos, ou de outros dados fornecidos à máquina, a fim de se objetivar um processamento.

2) Sistemas: conjunto de elementos, materiais ou ideais, entre os quais se possa encontrar ou definir alguma relação; disposição das partes, ou dos elementos de um todo, coordenados entre si, e que funcionam como estrutura organizada.

3) Sistemas de informação: não constavam da edição de dicionários da década de 1970.

E então? Conclui-se que sistemas de informação são algo novo, ou pelo menos uma nova disciplina.

E agora? Buscando definições mais operacionais, apresentadas no Quadro 1.

Ainda mais direto:

1) Informação é o conjunto de dados que, se fornecido sob forma e tempo adequados, melhora o conhecimento da pessoa que o recebe, e a habilita a desenvolver melhor determinada atividade, ou a tomar decisões melhores. A utilidade e o valor da informação é determinado por quem a usa nas suas ações e decisões, não sendo, em si mesma, uma característica dos dados; assim, a utilidade e o valor da informação dependem do contexto. 
direito à informação

e democracia

habeas data

Código de Ética Médica
2) Sistemas de Informação (SI) são sistemas que permitem a coleta, o armazenamento, o processamento, a recuperação e a disseminação de informações. Hoje, quase sem exceção, os SI baseiam-se no computador e apoiam as funções operacionais, gerenciais e de tomada de decisão.

Quadro 1 Conhecimento, informação e dado: definiçōes básicas

$\begin{array}{llll}\text { Termo } & \text { Conhecimento } & \text { Informação } & \text { Dados } \\ \text { Conceito } & \begin{array}{l}\text { 0 que é conhecido } \\ \text { por seres humanos. }\end{array} & \begin{array}{l}\text { Conhecimento, formalizado, } \\ \text { dos estados de um sistema } \\ \text { que pode ser transmitido } \\ \text { de um modo reprodutivel. }\end{array} & \begin{array}{l}\text { Representação da } \\ \text { informação que pode ser } \\ \text { utilizada como um meio } \\ \text { para a comunicação. }\end{array}\end{array}$

É só? Quase. Uma questão ainda fica: o papel essencial da informação na sociedade. O direito à informação é considerado, hoje, um aspecto fundamental da democracia. E o investimento de empresas, centros de pesquisa e governos em diversos aspectos da tecnologia da informação, entre os quais a Internet, é prova evidente de seu poder econômico. Na sociedade atual, ter a informação necessária, em tempo hábil, é vital, seja para impedir a disseminação de um surto de intoxicação, seja para cortar a propagação de boatos infundados, mas com grande potencial de criar confusão.

A Declaração Universal dos Direitos do Homem aborda o direito à informação em seu artigo 19॰: "Todo o indivíduo tem direito à liberdade de opinião e de expressão...". A Constituição brasileira de 1988 reafirma a liberdade de expressão intelectual (artística, científica e de comunicação), independente de censura ou licença, e garante a inviolabilidade do sigilo da correspondência, das comunicações telegráficas e telefônicas; esse sigilo somente pode ser quebrado por ordem judicial, e nos casos que impliquem crime. Criou-se o habeas data, meio jurídico concedido pela autoridade judiciária, e utilizado para garantir o acesso a informações constantes de registros, ou bancos de dados, de entidades governamentais, ou de caráter público.

O Código de Ética Médica impõe o sigilo quanto às informações confidenciais, relatadas ao médico no desempenho de suas funções, mesmo no trabalho em empresas, exceto nos casos em que seu silêncio prejudique, ou ponha em risco a saúde do trabalhador, ou da comunidade. Além disso, o médico deve denunciar às autoridades competentes quaisquer formas de poluição ou deterioração do meio ambiente, preju- 
diciais à saúde e à vida. Ou seja, informar é um dever. No caso das atividades da Vigilância Sanitária, é direito do cidadão ter acesso às informações que dizem respeito ao bem-estar da coletividade.

Também nos órgãos da área da informática discute-se a regulamentação ética do tratamento da informação: considera-se como sigilosa e confidencial toda informação que se obtiver em razão do trabalho, sendo vedada a divulgação da mesma sem o consentimento dos clientes e/ou empregadores.

Enfim, ao lidar com informação, embora às vezes esta pareça algo intangível, é fundamental lembrar que:

- o acesso aos dados que dizem respeito a um indivíduo lhe deve ser garantido (habeas data).

- o sigilo das informações, particularmente daquelas que podem prejudicar o indivíduo, em especial, no caso previsto na ética médica, deve ser preservado, garantindo-se, entretanto, o direito maior da coletividade (confidencialidade).

\section{Sistemas de Informação}

Sistema de Informação em Saúde (SIS) é todo e qualquer sistema que permita a coleta, o armazenamento, o processamento, a recuperação e a disseminação de informações, baseadas em computador, e que apoiam as funções operacionais, gerenciais e de tomada de decisão de interesse da saúde. Assim, o cadastro de pacientes de um médico em um consultório particular é um sistema de informação em saúde? Não. Em geral, só se considera um SIS o sistema que tem por objetivo apoiar atividades voltadas para a saúde coletiva, no âmbito da gestão, da vigilância ou da pesquisa. Existe uma enorme gama de informações relativas à saúde que podem ser informatizadas, e nem por isso serão abordadas neste tópico. O cadastro de pacientes, as informações do almoxarifado de um grande hospital, a lista de estabelecimentos de saúde da Secretaria Municipal, o Dicionário de Especialidades Farmacêuticas (DEF), informatizado, todos contém informações importantes para a saúde. Mas não são SIS.

Mas poderiam ser... se todas estas informações estivessem sendo utilizadas para, por exemplo, se avaliar a qualidade da assistência aos pacientes, verificar prazos de validade, origem de medicamentos e condições de armazenamento. O próprio DEF poderia estar na base de um SIS - com fluxos, periodicidade e rotina - se suas informações fossem complementadas com outras, provenientes do Ministério da Saúde, atualizadas em bases regulares, e tornadas disponíveis através da Internet. direito da coletividade 
Então, definimos SIS como uma ferramenta para melhorar o desempenho das pessoas nas suas atividades no setor saúde (Figura 1).

Tendo esta definição sempre em mente, é relativamente simples listar as principais qualidades de um SIS que ajudam a melhorar o desempenho das pessoas nas suas atividades:

1) Boa cobertura - Evitar perder informações é muito importante. A lista de farmácias deve ser o mais completa possível, o registro de óbitos deve incluir $100 \%$ das pessoas falecidas na localidade, permitindo uma visão completa do problema. Ou seja, o planejamento do processo de coleta da informação deve buscar ser abrangente.

2) Exatidão - A informação deve ser precisa, correta. O endereço registrado permite encontrar o estabelecimento; o registro do total de caixas de medicamentos adquiridas correspondem ao real. O tipo de ficha, a forma de coleta e a fonte da informação são importantes para a garantia da exatidão da informação.

3) Pontualidade - A informação deve estar disponível em tempo hábil, para permitir tomar-se a decisão acertada; de pouco adianta saber de uma epidemia de sarampo depois que a epidemia já acabou. A pontualidade das informações é garantida pela adequada periodicidade da coleta ou da atualização dos dados.

Diversos outros aspectos também devem ser considerados. Por exemplo, quanto tempo se pode dispender para conseguir boa informação? Qual o custo de manter os dados sempre atualizados? Será necessária a informação pedida nesta ficha? (Figura 2)

Graças a uma metáfora, é possível comparar equívocos na estruturação dos sistemas de informação a dois problemas de saúde bastante atuais: obesidade e sedentarismo.

Figura 1 Sistema de Informação, informação e dado

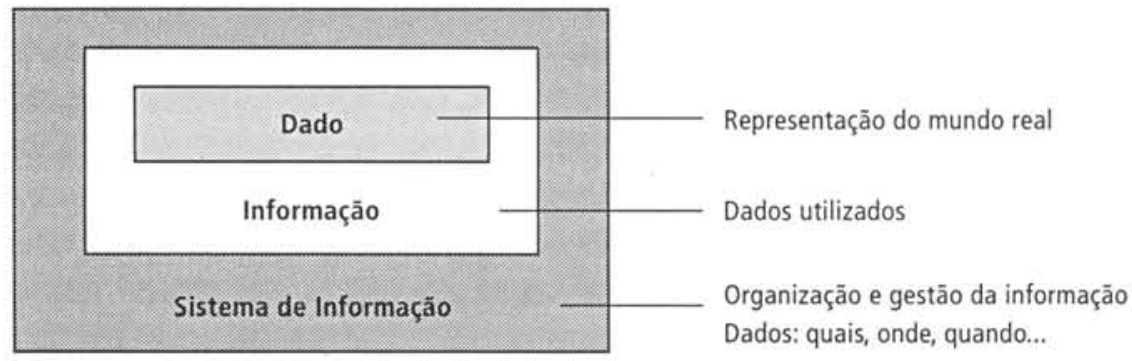




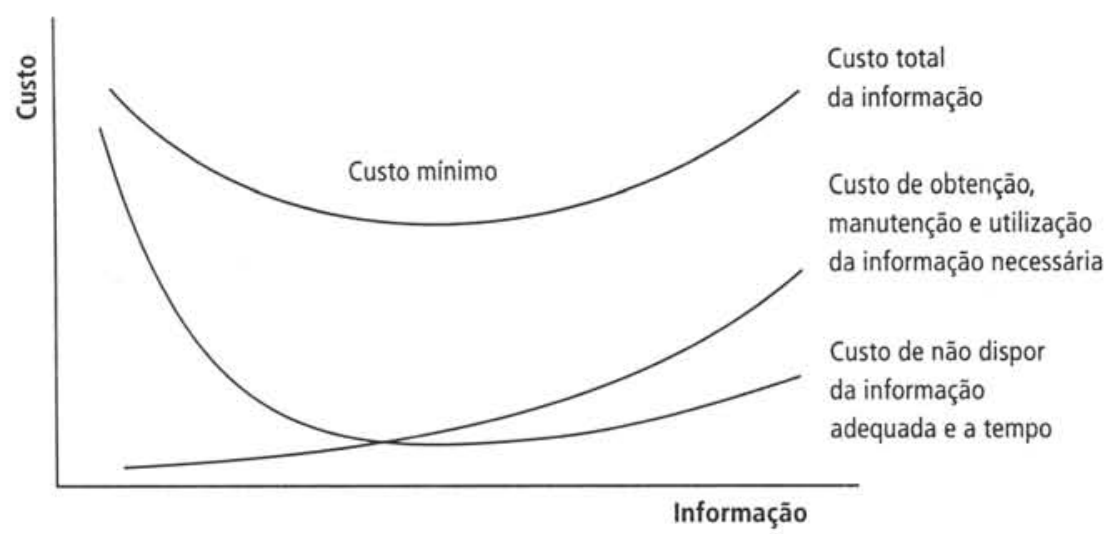

A obesidade do sistema de informação é causada pelo excesso de dados coletados, muito acima da capacidade real dos interessados em assimilá-los. Ou seja, coletar informações sobre a cor dos olhos da pessoa que apresentou intoxicação alimentar é, evidentemente, pouco importante. Eventualmente não é tão simples decidir sobre a importância da informação, sendo bastante comum a tendência a incluir mais e mais dados, simplesmente porque parece viável ou porque não irá aumentar tanto assim o questionário, ou porque poderá ser útil posteriormente. Entretanto, o custo da informação - coleta, digitação, armazenamento -, aliado à crescente dificuldade de se extrair o que é realmente importante da massa de dados, deve ser um freio.

O sedentarismo é a falta de exercício do sistema, a não-utilização da informação. Por vezes o dado não apresenta boa qualidade. Porém somente utilizando a informação produzida será possível melhorar a qualidade da mesma, apontar os erros e estimular quem produz o dado a aperfeiçoar seu trabalho (Figura 3).

A disseminação da informação deve ser feita em três níveis:

- à sociedade em geral, como principal interessada na informação sobre saúde. A produção do conhecimento que não busca a mais ampla disseminação, acaba por se tornar atividade estéril, e tende a se tornar arquivo morto dos órgãos de Saúde Pública;

- aos responsáveis pela produção do dado; a retroalimentação é indispensável para reforçar a importância do dado e garantir o interesse do informante na manutenção e no aperfeiçoamento das suas atividades;

disseminação da informação 
Figura 3 Utilidade da informaçāo

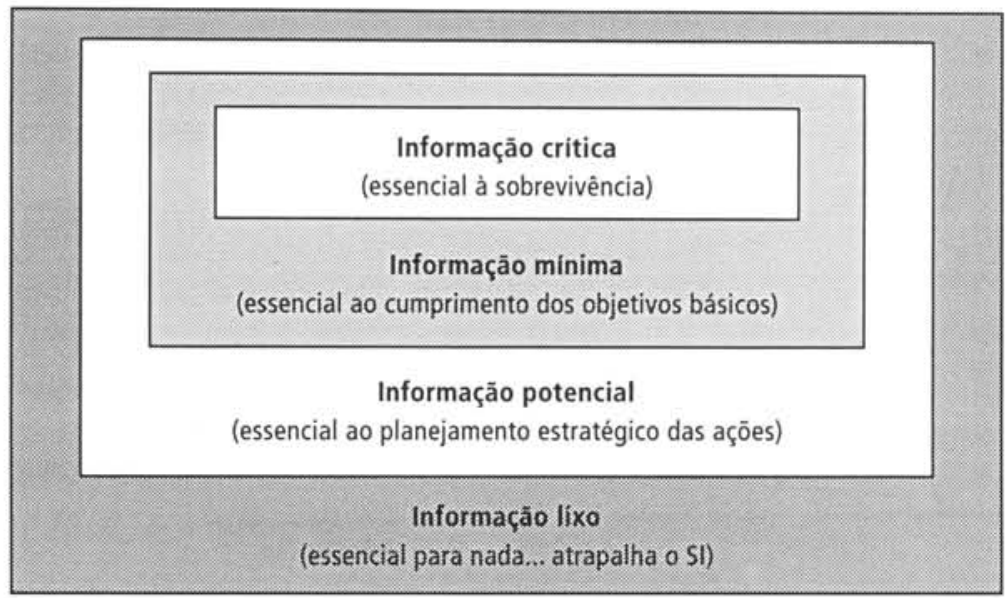

sistemas de abrangência nacional

\section{Informações em saúde e Vigilância Sanitária}

Os SISs podem informar sobre eventos em todos os municípios do território, em apenas alguns Estados, em unidades de saúde especiais, ou, apenas, em um município. Os sistemas de abrangência nacional mais conhecidos (e utilizados) são:

- SIM - Sistema de Informações de Mortalidade;

- SINASC - Sistema de Informações de Nascidos Vivos;

- SIH-SUS - Sistema de Informações Hospitalares;

- SIA-SUS - Sistema de Informações Ambulatoriais;

- SINAN - Sistema de Informações de Agravos de Notificação.

As informações geradas por estes sistemas se relacionam com diversas outras, de forma a se conhecer do que morrem os brasileiros, ou qual causa de internação isolada apresenta o maior gasto de recursos do Ministério da Saúde. As respostas a essas perguntas são fáceis para quem tem acesso aos dados gerados pelo SIM e pelo SIH-SUS. Por exemplo, em 1996, o grupo de causas de óbito mais freqüente em todos os Estados do país (exceto Roraima, Acre, Rondônia e Amapá, onde as Causas Externas predominam), era o das Doenças Cardiovasculares, com $27,5 \%$ do total de mortes; em setembro de 1998 , a maior fonte de 
gastos do SUS com o pagamento de atos médicos foram as cirurgias, com $34,9 \%$ do gasto total.

É fácil constatar essa realidade, uma vez que os dados estão na Internet (www.datasus.gov.br). Ou seja, cada óbito ocorrido no país é atestado, recolhido, codificado, digitado, corrigido e posto à disposição de quem se interessa em estudar as causas de mortalidade; cada internação paga pelo SUS pode ser computada para avaliar gastos públicos, ou o perfil de utilização de serviços hospitalares. Evidentemente, para cada análise, o tipo de dado necessário é diferente, e cada sistema de informações tem suas formas e seus formulários de coleta.

A Vigilância Sanitária pode utilizar (e utiliza) diversos destes sistemas. A notificação de toxinfecção alimentar informa sobre as más condições de preparo e consumo de alimentos; a alta mortalidade em berçário neonatal indica possível surto de infecção hospitalar; o aumento do número de casos de malformação fetal pode dever-se à utilização de medicamento contra-indicado para a gestação (como se deu com a talidomida). Algumas informações, entretanto, são de interesse principalmente da Vigilância Sanitária, como as informações sobre produtos registrados e empresas autorizadas.

O Quadro 2 resume o tipo de informação e a finalidade de dois importantes cadastros de atividades de Vigilância Sanitária.

Estes cadastros têm em comum a proposta de atingirem cobertura de $100 \%$. Ou seja, todas as empresas e todos os produtos deverão constar destes sistemas de informações. E passam a se chamar sistemas de informações à medida em que existe regularidade na coleta e na análise dos dados, e dão origem a informações que irão orientar os usuários e a fiscalização.

Outros sistemas trabalham com quadros parciais da realidade, perfeitamente adequados a seus objetivos. É o caso do SINITOX - Sistema Nacional de Informação Tóxico-Farmacológica (www.fiocruz.br/ cict/oquee/estrut/dect/sinitox/apresent.htm). Este sistema constituiu-o, em 1980, o Ministério da Saúde, depois de constatada a necessidade de se criar um sistema abrangente de informação e documentação em Toxicologia e Farmacologia, de alcance nacional. Esse sistema deveria ser capaz de fornecer informações precisas sobre medicamentos, e demais agentes tóxicos existentes em nosso meio, às autoridades de Saúde Pública, aos profissionais de saúde e de áreas afins, e à população em geral. O sistema se baseia na rede de Centros de Controle de Intoxicações existentes no país. Em 1985 o país contava com quinze destes centros e, em 1997, passou a contar com trinta e um, localizados em dezesseis Estados brasileiros. Ou seja, ainda que nem todos os casos de intoxicação sejam conhecidos, este sistema de informações

\section{www.datasus.gov.br}

\section{Sistema Nacional}

de Informação TóxicoFarmacológica (SINITOX) 


\section{Subsistema de Informações de produtos registrados}

Descrição

Origem/fonte

Período e região

de abrangência

Atualização

Variáveis
Contém informaçōes administrativas e técnicas a respeito de produtos (alimentos, cosméticos e saneantes) com o objetivo de gerenciar e fiscalizar sua qualidade e conceder registro no órgão competente do Ministério da Saúde. Abrange Secretarias de Vigilância Sanitária (SVS), Secretarias Estaduais de Saúde (SES), Delegacias de Fiscalização Sanitária (DFS) e órgãos de proteção ao consumidor.

Documentação técnica oriunda das empresas

A partir de 1984, Brasil

\section{Eventual}

Nome do produto

Nome da empresa

Tipo de produto

Tipo de embalagem

Fórmula química

Composição

Subsistema de Informaçōes sobre empresas autorizadas

Descriçāo

Origem/fonte

Periodo e regiāo

de abrangência

Atualização

Variáveis
Contém cadastro das empresas, para fins de controle de produtos registrados na Secretaria de Vigilância Sanitária*, e fornece informações sobre as atividades das empresas e a classe dos produtos que as mesmas comercializam/produzem.

Documentação técnica oriunda das empresas

A partir de 1984, Brasil

Eventual

Razão social

Origem (nacional ou estrangeira)

Representante legal

CGC

Atividade

Classe de produtos

Endereço completo

Fonte: proveniente do DATASUS - http://www.datasus.gov.br/dirbd/area/tema06.htm

- http://www.svs.saude.gov.br 
permite diagnosticar a situação de forma bastante útil. Assim, sabe-se que:

- os medicamentos (13.727 casos) e os animais peçonhentos (11.672) somaram, juntos, 50,5\% do total de casos de intoxicação no Brasil em 1997; - crianças de 1-4 anos de idade (10.342 casos), adultos de 20-39 anos (16.642), concentraram $53,7 \%$ dos casos registrados pelo SINITOX.

Neste caso, o sistema trabalha com os dados originados pelos centros de assistência toxicológica, cujo objetivo principal é o de orientar profissionais de saúde na assistência a casos de intoxicação e de envenenamento humanos, com base em informação sobre centenas de produtos, e seus possíveis efeitos.

Um outro sistema de informações baseia-se em amostra de nascimentos hospitalares, obtida através de Estudo Colaborativo Latino Americano de Malformações Congênitas - ECLAMC. E tem por objetivo identificar fatores de risco genéticos e ambientais, de defeitos congênitos, inclusive picos anormais na ocorrência desses defeitos. Neste caso, as fontes de informações também não garantem o registro da totalidade de casos, mas permitem conhecer, detalhadamente, diversas informações sobre um número limitado de crianças incluídas na amostra. E permitem comparar um valor esperado de casos de malformações naquela população com o número de casos efetivamente ocorridos, assim orientando os órgãos de saúde quanto a epidemias. Além disso, boatos, rumores, notícias de jornal a respeito de malformações congênitas são investigados.

De grande importância para a Vigilância Sanitária é o SINAN - Sistema de Informaçōes de Agravos de Notificação. Através desse sistema, recolhem-se informações sobre a ocorrência de diversos agravos à saúde, de notificação obrigatória. Todos os serviços de saúde devem informar aos órgãos responsáveis das Secretarias de Saúde os casos diagnosticados de qualquer destas doenças. Cada doença tem uma ficha para registro de suas principais peculiaridades. As informações mínimas são:

- serviço: número da notificação, responsável pela notificação, identificação da unidade, data do registro;

- identificação do paciente: nome, data de nascimento (ou idade), sexo, instrução, endereço de residência (o mais completo possível, com CEP, bairro, etc.), etnia (se for índio);

- caracterização do agravo: data do início dos sintomas, e demais características de importância.

O Quadro 3 apresenta o conjunto dos agravos notificados, acompanhados de um breve resumo dos principais objetivos do SIS para cada um.
Estudo Colaborativo Latino Americano de Malformaçōes Congênitas (ECLAMC)

Sistema de Informações de Agravos de Notificação (SINAN) 
Quadro 3 Agravos do SINAN e respectivos objetivos

\begin{tabular}{|c|c|}
\hline Agravo & Principais objetivos do SIS \\
\hline $\begin{array}{l}\text { Acidentes com } \\
\text { animais peçonhentos }\end{array}$ & Orientar e controlar a utilização de soro \\
\hline $\begin{array}{l}\text { Contato humano } \\
\text { de raiva animal }\end{array}$ & $\begin{array}{l}\text { Orientar e controlar o tratamento com soro e controlar } \\
\text { o acompanhamento do animal }\end{array}$ \\
\hline Raiva humana & Identificar a história do contato \\
\hline Coqueluche & Acompanhar a eficácia da vacinação DPT \\
\hline Difteria & Acompanhar a eficácia da vacinação DPT \\
\hline $\begin{array}{l}\text { Doença exantemática } \\
\text { (sarampo, rubéola) }\end{array}$ & Acompanhar a eficácia da vacinação \\
\hline Febre amarela & Identificar o local do contágio e a história de vacinaçāo \\
\hline Dengue & Identificar o local do contágio e a presença de mosquitos \\
\hline $\begin{array}{l}\text { Leishmaniose } \\
\text { tegumentar americana }\end{array}$ & Identificar o local do contágio e a presença de animais infectados \\
\hline Leishmaniose visceral & Identificar o local do contágio e a presença de animais infectados \\
\hline Esquistossomose & $\begin{array}{l}\text { Identificar o contato com água onde existe o caramujo e verificar } \\
\text { condição de saneamento }\end{array}$ \\
\hline Leptospirose & Identificar história de enchentes e contato com ratos \\
\hline Meningite & $\begin{array}{l}\text { Identificar o tipo (meningocócica, viral ou outras), } \\
\text { controlar contatos e vacinação }\end{array}$ \\
\hline Hanseniase & Fazer o seguimento do caso e de contatos \\
\hline Hepatites virais & $\begin{array}{l}\text { Caracterizar os diferentes tipos de transmissāo (água - tipo A; } \\
\text { hemoderivados e sexual as demais) para controlar o contágio }\end{array}$ \\
\hline Tuberculose & $\begin{array}{l}\text { Seguimento do caso, relação com AIDS, resistência } \\
\text { a medicamentos }\end{array}$ \\
\hline Pneumoconioses & Relacionar com a ocupação e a empresa \\
\hline $\begin{array}{l}\text { Intoxicação } \\
\text { por agrotóxico }\end{array}$ & Relacionar com ocupação, tipo de sintoma, contato com produtos \\
\hline
\end{tabular}


Quadro 3 (continuação)

$\begin{array}{ll}\begin{array}{l}\text { Agravo } \\ \text { Tétano acidental }\end{array} & \begin{array}{l}\text { Principais objetivos do SIS } \\ \text { Tétano neonatal }\end{array} \\ \begin{array}{l}\text { Verificar história de ferimentos e vacinação } \\ \text { ao parto }\end{array} \\ \begin{array}{l}\text { Sindrome da } \\ \text { rubéola congênita da gestante e condições de assistência }\end{array} \\ \begin{array}{l}\text { Sifilis congênita } \\ \text { Doenças sexualmente }\end{array} & \text { Relacionar ao pré-natal e à realização de exames e tratamento } \\ \text { transmissiveis } & \text { Identificar contágio materna e a vacinação } \\ \text { AIDS } & \begin{array}{l}\text { Identificar forma de contágio (hemoderia de tratamento } \\ \text { uso de drogas) e acompanhar contatos }\end{array}\end{array}$

Alguns destes agravos guardam relação fundamental com a Vigilância Sanitária, sendo fundamental utilizar estas informações e trabalhar, em conjunto, com a Vigilância Epidemiológica. São de particular importância:

- dengue, leptospirose, leishmaniose, esquistossomose (por envolverem aspectos ambientais);

- hepatite $B$, hepatite $C$, AIDS (em virtude de sua relação com o controle de hemoderivados);

- pneumoconioses, intoxicação por agrotóxicos (em virtude de sua relação com o ambiente de trabalho).

Outro SIS, de grande relevo para as atividades relacionadas ao ambiente de trabalho, baseia-se na CAT, a Comunicação de Acidentes de Trabalho. Este sistema é gerenciado pelo DATAPREV, empresa de Processamento de Dados da Previdência Social. Contém informações sobre acidentes de trabalho comunicados ao INSS, desde 1993. E se volta para o cadastramento e o histórico dos acidentes de trabalho, independente da geração ou da concessão de benefício.

O Quadro 4 resume os principais Sistemas de Informações de interesse para a saúde.

Uma questão importante diz respeito à localização de todas estas informações, que depende de informação geográfica. A localização espacial dos eventos em saúde é particularmente importante para:
Comunicação de Acidentes de Trabalho (CAT) 
- estudar fatores ambientais de difícil detecção ao nível do indivíduo; por exemplo, a possível contaminação por metais pesados ao redor de fábricas e a localização espacial da população exposta.

- analisar gradiente de risco de grupos populacionais - estudos ecológico-espaciais; a delimitação de áreas homogêneas para orientar as ações necessárias e organizar a intervenção, é o procedimento tradicionalmente utilizado no controle de endemias e na seleção de estratégias de intervenção.

Quadro 4 Sistemas de Informaçōes, segundo tema

\begin{tabular}{|c|c|c|}
\hline Área & Tema & Sistemas \\
\hline \multirow[t]{3}{*}{ Demografia } & Nascimentos & Sistema de Informações sobre Nascidos Vivos - SINASC \\
\hline & Óbitos & Sistema de Informaçōes de Mortalidade - SIM \\
\hline & Populaçāo & Censos, contagens e estimativas do IBGE \\
\hline \multirow[t]{8}{*}{ Morbidade } & Doenças transmissiveis & Sistemas de Informaçōes de Agravos de Notificação - SINAN \\
\hline & Câncer, doenças mentais, infecçōes hospitalares & Sistemas de Informações de Agravos sob Registros Especiais \\
\hline & Incapacidades, absenteismo, exames de saúde & Sistemas periciais (alguns relacionados ao INSS) \\
\hline & Morbidade institucional & Sistema de Informações Hospitalares - SIH-SUS \\
\hline & & Sistema de Informaçōes Ambulatoriais - SIA-SUS \\
\hline & & Sistema de Gerenciamento de Unidade Ambulatorial \\
\hline & & Básica - SIGAB \\
\hline & Acidentes de trabalho & Sistemas de informaçōes sobre acidentes \\
\hline \multirow{5}{*}{$\begin{array}{l}\text { Produção } \\
\text { de serviços }\end{array}$} & Ambulatórios conveniados ao SUS & SIA-SUS \\
\hline & Hospitais conveniados SUS & SIH-SUS \\
\hline & Programa de Imunizações & Subsistema de Avaliação do Programa de Imunizaçōes - API \\
\hline & & Subsistema de Estoque e Distribuição de Imunobiológicos - EDI \\
\hline & Exames Laboratoriais & $\begin{array}{l}\text { Sistema de Informação Laboratorial para Exame } \\
\text { Colpocitopatológico }\end{array}$ \\
\hline $\begin{array}{l}\text { Alimentação } \\
\text { e nutrição }\end{array}$ & Estado nutricional & $\begin{array}{l}\text { Sistema de Informação de Vigilância Alimentar } \\
\text { e Nutricional - SINVAN }\end{array}$ \\
\hline
\end{tabular}


As informações geográficas organizam-se através do SIG - Sistema de Informações Geográficas, um sistema digital de captura, armazenamento, recuperação, análise e apresentação de dados espaciais. A utilização do SIG na área da saúde vem crescendo, graças a seu poder de integrar diversas informações sobre a saúde da população através da localização espacial. Com este recurso, por exemplo, é possível analisar a distribuição das gestantes que fizeram uso de anticoncepcional ineficaz, através de mapeamento da área de distribuição de maior número de cartelas ineficazes. E orientar, assim, um levantamento sistemático das farmácias da região, a fim de se apreender o produto e de se identificar os distribuidores envolvidos na fraude.

A implantação de um SIG, entretanto, não é tarefa simples, sendo necessariamente fruto da articulação de diferentes órgãos, nem sempre apenas da área da saúde. Mas é importante ter em mente a possível utilização, de um SIG e, assim, não esquecer que o adequado registro de endereços é condição indispensável para a eventual utilização do mesmo.

Retornamos, então, à definição de SIS: um instrumento para melhorar o desempenho das pessoas nas suas atividades no setor saúde, através da oferta de informação pertinente, com as adequadas coberturas, e exatidão, na hora certa.

\section{Construindo um sistema de informação para a Vigilância Sanitária}

Com a ajuda desses exemplos, podemos começar a pensar em como se constrói um sistema de informações. Antes de mais nada, sistema de informações sobre o quê? Em que nível, com que detalhamento? Suponhamos que seja o momento de pensar um sistema de informações municipal - SUS - que tenha como propósito geral orientar as ações da Vigilância Sanitária. Por onde começar? Devemos começar definindo, claramente, o objetivo do sistema; assim, sempre será possível recorrer a esta definição para evitar o excesso de informação.

Objetivo: permitir a análise e o monitoramento dos fatores de risco para a saúde relacionados a produtos, serviços e ambiente, com base nas informações coletadas no curso dos procedimentos de Vigilância Sanitária (inspeções, coletas de amostras, análise laboratoriais, investigações).

Assim, este sistema de informações - que poderia ser chamado "Sistema de Informações para as Ações da Vigilância Sanitária/ SIAVS" - terá como base as próprias atividades da Vigilância Sanitária. Mas, infor-
Sistema de Informaçöes Geográficas (SIG) 
mações importantes e úteis, por exemplo, sobre a ocorrência de toxiinfecções, embora relacionadas ao propósito geral de um sistema de informações para a Vigilância Sanitária, não serão parte daquele sistema.

O SIAVS permitirá obter:

- o registro de cada estabelecimento, acompanhado das informações referentes a todos os relatórios das atividades desenvolvidas - inspeções, laudos de análises laboratoriais, multas aplicadas, etc. - assim caracterizando um sistema de controle de qualidade de estabelecimentos;

- o perfil da atuação da Vigilância Sanitária.

Como então estruturar este sistema? Comecemos por definir como estas informações se relacionam. Na Figura 4 o sistema é alimentado por diversos tipos de informações.

As linhas a ligarem o tipo de informação ao núcleo do sistema são pontilhadas, exceto aquela das ações de Vigilância. Assim se procurou ressaltar que, embora, todas as informações apresentadas no diagrama tenham importância para a Vigilância Sanitária, apenas aquelas refe-

Figura 4 Integração da informação para a Vigilância Sanitária

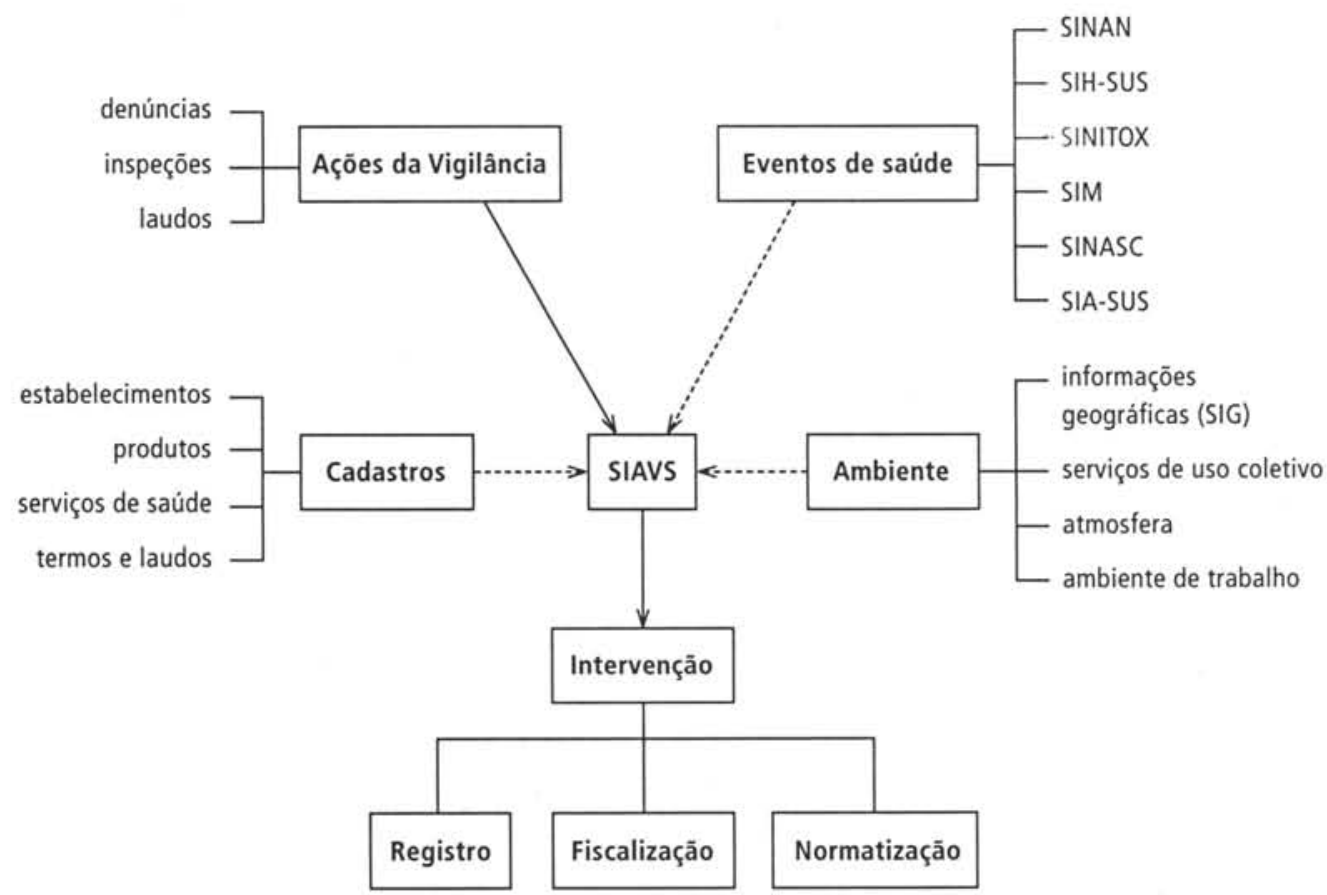


rentes às ações da própria Vigilância são geradas internamente; as demais têm origem nos mais diversos órgãos, a saber:

1) Eventos de saúde - Junto à Vigilância Epidemiológica (SINAN), ao núcleo de epidemiologia, e sendo para o município, via Internet, na página do DATASUS (www.datasus.gov.br); esta página é permanentemente atualizada, e traz diversas informações muito úteis, inclusive demográficas e socioeconômicas, além de permitir tabulações simples dos dados;

2) Ambiente - Estas informações estão dispersas em diversos locais, e em cada município apresentam peculiaridades;

3) Cadastros - Parte destes cadastros estão na própria Vigilância Sanitária, pois a necessidade da concessão de alvará de funcionamento permite organizar estas informações. Além disso, nos órgãos de classe associações comerciais, sindicatos - e nos demais órgãos de fiscalização municipal e estadual é possível obter, ainda que desorganizadamente, as bases iniciais para um cadastro abrangente dos estabelecimentos sujeitos à fiscalização da Vigilância Sanitária.

Organizemos, então, o subsistema de informações relativas às ações da própria Vigilância Sanitária. Em primeiro lugar, como este subsistema deverá relacionar-se aos demais, é imprescindível cada estabelecimento ter um código de identificação, o mesmo existente nos cadastros. Ou seja, através do código do estabelecimento poderemos obter a história de cada estabelecimento, e recuperar todas as informações constantes nos cadastros, e todas as ações da Vigilância realizadas em cada local.

Um problema comum na estruturação de bancos de dados é a designação de códigos. A tentação, em geral, é atribuir um número a cada estabelecimento visitado, desde o 0001, e em seqüência. Esta não é a melhor solução. Depois de cem estabelecimentos codificados, como descobrir o código "daquela padaria que visitamos em abril?". A primeira recomendação é utilizar os códigos já existentes, seja nos alvarás emitidos na própria Secretaria, seja nos cadastros dos órgãos de classe. Além disso, é interessante utilizar uma numeração estruturada, em que, por exemplo, os dois últimos dígitos depois do traço permitam classificar o estabelecimento conforme o tipo - alimentação, farmácia, cabeleireiro, consultórios, clínicas, etc. Mas, como a criação de cadastros é assunto para livros inteiros, cabem, aqui somente duas sugestōes essenciais: pensar na forma de codificar, antes de começar a atribuir números, e, se possível, utilizar identificadores já existentes.

Uma vez garantida a possibilidade de juntar informações de diferentes origens, através do código de identificação, se deve definir os dados a serem registrados, ou quais campos serão coletados em cada www.datasus.gov.br

código de identificação 
arquivo

formato

formulário atividade da Vigilância Sanitária. Nos sistemas de informações definidos anteriormente trabalha-se, em geral, com informações digitais, ou seja, utilizam-se computadores. Neste caso, os dados a serem analisados ficam arquivados em bancos de dados.

Um arquivo em computador consiste em um conjunto de informações gravadas em algum meio físico - disco rígido, disco flexível, CDROM. Um documento a ser lido em processador de texto é um arquivo, um programa a ser executado também se guarda no computador como um arquivo, e, ainda, um conjunto de dados sobre os estabelecimentos de saúde é guardado como um arquivo. Para se ler um arquivo do tipo documento é necessário um programa de computador capaz de lê-lo. Um arquivo do tipo banco de dados também precisa de um programa, denominado gerenciador de bancos de dados; existem diversos destes programas, comerciais e de domínio público. Mas nem sempre é simples mudar de programa ou importar os dados de um formato para outro, pois cada programa arquiva os dados de uma maneira particular (chamada formato).

A estrutura usual de um banco de dados é apresentada no Quadro 5. Cada variável será registrada em um campo do banco de dados. No exemplo acima, as características do estabelecimento (endereço, nome, CGC, etc.) estariam em outro banco de dados, o cadastro de estabelecimentos. Observe-se, ainda, que os campos estão preenchidos com números (exceto a data). A prática usual é esta: todas as possíveis respostas, para cada campo, são codificadas previamente, e registra-se o código. Desta forma, padroniza-se o que será, de fato, objeto de coleta e de digitação.

Para tornar viável a criação deste banco de dados é necessário cada procedimento da Vigilância Sanitária dispor de um formulário próprio, em que a coleta de informações seja padronizada, e cada variável seja

Quadro 5 Banco de dados-exemplo

\begin{tabular}{ccccc}
\hline Campo 1 & Campo 2 & Campo 3 & Campo 4 & Campo N \\
$\begin{array}{c}\text { Código do } \\
\text { estabelecimento }\end{array}$ & $\begin{array}{c}\text { Tipo de } \\
\text { infração }\end{array}$ & Datas & Medidas & Responsável \\
\hline $123-4$ & 2 & $12 / 09 / 1998$ & 4 & 23 \\
\hline $098-0$ & 1 & $13 / 10 / 1998$ & 2 & 21 \\
\hline$\ldots . .$. & $\ldots . .$. & $\ldots . .$. & $\ldots .$. \\
\hline
\end{tabular}


muito bem definida, para que se obtenha a informação necessária, independente da pessoa a colher o dado. Os elementos que podem vir a constituir um sistema de informações das atividades da Vigilância Sanitária são:

- roteiros, ou relatórios de inspeção;

- notificações de denúncia;

- termos de coleta de amostras de produtos ou de elementos ambientais;

- outros instrumentos de registro de procedimentos da Vigilância Sanitária;

Algumas variáveis são fundamentais, em todos os elementos:

- o local alvo do procedimento (devidamente codificado!!!);

- o procedimento realizado;

- a origem do evento que levou ao procedimento;

- a finalidade do procedimento;

- outros procedimentos (por exemplo, o envio de amostra a laboratório; o resultado do exame será incorporado posteriormente);

- os recursos humanos envolvidos.

Com base nos arquivos organizados no gerenciador de banco de dados, como extrair a informação desejada? Algumas funções são próprias deste tipo de programa: ordenação, busca, contagem. Ou seja, colocar os dados em ordem é muito simples, pois qualquer variável serve para tanto. É possível ordenar o banco de dados, do exemplo acima, pela data da inspeção, pelo código do estabelecimento ou pelo funcionário responsável pela inspeção. Buscar todas as inspeções realizadas na empresa n² 048 , ou contar por quantas inspeções a mesma já passou também é fácil, pois cada uma destas operações exige apenas um comando, ou um clique no mouse. Cruzar duas informações, e situá-las em tabelas, já não é tão simples, e implica, em geral, o uso de um pacote estatístico.

Existem inúmeros softwares de estatística, sendo dois muito utilizados nos serviços de saúde no Brasil, por serem de domínio público e desenhados segundo demandas da área da saúde. O mais antigo, e conhecido, mundialmente, é o EPI-INFO, já na sua versão 6, um programa desenvolvido no CDC (Center for Disease Control nos EUA), de domínio público, ou seja, gratuito; o EPI-INFO pode ser obtido através da Internet, no seguinte endereço: www.cdc.gov/epo/epi/epiinfo.htm.

Este programa tem diversos módulos, inclusive um pequeno editor de textos, um banco de dados, e um programa estatístico. Utilizando-o, é possível, e razoavelmente simples, montar a ficha de coleta da informação, registrar a entrada do dado (criação e digitação do banco de dados), tabular variáveis, calcular média, ver gráficos, entre diversas variáveis

EPI-INFO

www.cdc.gov/epo/epi/ epiinfo.htm 
www.datasus.gov.br/ tabnet/tabnet.htm

TabWin

www. datasus.gov.br/ tabwin/tabwin.htm outras funções. Existe um manual EPI-INFO em português, que o Departamento de Medicina Coletiva da Escola de Medicina da Santa Casa de São Paulo fornece. E o programa vem acompanhado de tutoriais, que auxiliam bastante a utilização do mesmo.

O outro programa é nacional, e desenvolvido pelo DATASUS. Foi criado para atender a necessidade de se dispor de um instrumento, simples e rápido, para realizar tabulações com dados dos sistemas de informações do Sistema Único de Saúde. Existem três versões: a mais antiga, para DOS, uma recomendada para computadores que utilizam o Windows ${ }^{\mathrm{TM}}$ e uma versão para utilização através da rede, para tabulações rápidas on line. A página www.datasus.gov.br/tabnet/tabnet.htm apresenta a possibilidade de se produzir tabulações dos mais diversos assuntos, segundo as principais bases de dados secundárias do país, desde o censo demográfico até a mortalidade. É possível, assim, por exemplo, saber a proporção de residências com coleta de lixo regular, por município, de cada estado, ou o total de doses de vacina aplicadas.

O TabWin permite construir índices e indicadores de produção de serviços, de características epidemiológicas (incidência de doenças, agravos e mortalidade) e dos aspectos demográficos de interesse (educação, saneamento, renda, etc.), por Estado e por município. Além disso é possível importar as tabulações efetuadas na Internet (geradas pelo aplicativo TABNET), realizar operações aritméticas e estatísticas nos dados da tabela gerada ou importada pelo TabWin, e elaborar gráficos de vários tipos, inclusive mapas, com base nos dados dessa tabela. Para dispor deste programa, basta acessar a página do DATASUS (www.datasus.gov.br/), ou ir direto à página do software: www.datasus. gov.br/tabwin/tabwin.htm.

\section{Sistema de informação para a Vigilância Sanitária: a experiência do Estado de São Paulo*}

Ante a inexistência, no Brasil, de Sistemas de Informações em Vigilância Sanitária (SIVISA), estruturados e integrados, construiu-se o sistema apresentado a seguir, baseado na experiência de implantação no Centro de Vigilância Sanitária da Secretaria de Estado da Saúde.

Na primeira etapa da construção deste sistema deu-se a padronização dos procedimentos de Vigilância Sanitária, tendo como base as grandes áreas de atuação: Serviços de Saúde, Produtos, Saúde do Traba-

\footnotetext{
- Este item teve a participação de Maria Luiza Stucchi.
} 
lhador e Meio Ambiente. Os critérios utilizados para a definição dos procedimentos basearam-se na complexidade de execução, no tipo de atividade desenvolvida, por tipo de estabelecimento alvo da ação, no nível de conhecimento e/ou especialização do profissional de Vigilância, e na necessidade de equipamentos, instrumentos técnicos, normas e legislações específicas. Além de necessária na execução da atividade, a padronização é indispensável para a coleta da informação. A lista de procedimentos, criada após avaliação de todos os Estados, passou a compor a tabela de procedimentos do SIA-SUS (Quadro 6).

Quadro 6 Procedimentos em Vigilância Sanitária - SIA-SUS

Procedimento Definição

Inspeção sanitária Procedimento que busca levantar e avaliar, in loco, os riscos à saúde da população, presentes na produção e na circulação de mercadorias, na prestação de serviços, na intervenção sobre o meio ambiente, inclusive o de trabalho, e as identificação e notificação das medidas de correção conforme legislação vigente.

Coleta de amostra

Procedimento de caráter fiscal, que inclui as colheitas de amostras de produtos/substâncias relacionadas à saúde, ou que tenham efeito sobre a mesma.

Educação e comunicação em Vigilância Sanitária
Procedimento que se refere às atividades planejadas de educação e comunicação, com o objetivo de promover a adoção de comportamentos, atitudes e práticas sanitárias e de veicular informaçōes sobre a produção e a circulação de mercadorias, a prestação de serviços, o meio ambiente e 0 ambiente de trabalho.

$\mathrm{Na}$ etapa seguinte deu-se a estruturação do SIVISA, descentralizado e hierarquizado. Estes dois adjetivos, quase um jargão da área de sistemas de informações em saúde, significam apenas que o fluxo de informações será decidido de comum acordo entre as várias instâncias a atuarem na Vigilância Sanitária. E que as informações serão utilizadas nos vários níveis local, regional e central, a fim de se atender às instâncias de planejamento na elaboração de políticas em Saúde Coletiva.

Para pôr em prática a NOB/96, a partir de sua publicação, iniciouse a discussão sobre a padronização dos procedimentos de Vigilância 
módulos do sistema

instrumentos de coleta
Sanitária, segundo suas grandes áreas de atuação: Serviços de Saúde, Produtos, Saúde do Trabalhador e Meio Ambiente. A preocupação básica durante a elaboração de sistema foi a de facilitar a compreensão dos usuários. Por isso, partiu-se de um sistema já conhecido, o Sistema de Informação Ambulatorial - SIA/SUS - fazendo-se uso de suas tabelas complementares. Acrescentaram-se a este sistema particularidades da Vigilância Sanitária, como por exemplo, códigos específicos, de forma a contemplar as necessidades dos profissionais de Vigilância Sanitária.

O sistema contém três módulos: cadastro, produção e profissionais. O nível básico do sistema é o município, onde se realiza a coleta da informação, e que é a primeira instância a trabalhar a mesma. Os níveis regional e estadual também recebem as informações, que devem ser repassadas, em tempo hábil, para a tomada de decisão e o planejamento das ações.

A estrutura básica do sistema define a utilização de três instrumentos de coleta: ficha de cadastro de estabelecimentos, ficha de cadastro de unidade/equipe executora e ficha de procedimentos de Vigilância Sanitária. Cada instrumento gera um banco de dados e todas as informações se complementam, sendo possível efetuar os cruzamentos pertinentes à cada instância do Sistema Único de Saúde.

$\mathrm{O}$ cadastro dos estabelecimentos permite conhecer o universo de atuação, de forma a se programarem, executarem e avaliarem as ações de Vigilância Sanitária. Este cadastro permite conhecer o total de estabelecimentos segundo:

- tipo e ramo de atividade (Classificação Nacional de Atividades Econômicas do Ministério do Trabalho);

- risco e área de abrangência (município, estado);

- total de empregados;

- total de empregados terceirizados;

- regime legal (públicos ou privados) e atividade econômica.

Definido o universo de atuação, o segundo passo é cadastrar os recursos envolvidos nas atividades da Vigilância Sanitária, recursos humanos e de equipamentos. O banco de dados de unidade/equipe fornece as seguintes listagens para responder a estas questões:

- funcionários credenciados para executar ações de Vigilância Sanitária;

- total de funcionários credenciados;

- número de equipes de Vigilância Sanitária;

- número de funcionários por categoria profissional;

- relação de equipamentos existentes.

O banco de dados de produção permite avaliar as atividades, e deve responder às seguintes questões: 
- total de procedimentos realizados, por tipo (inspeção, coleta de amostra, educação);

- total de procedimentos executados, por profissional;

- total de procedimentos realizados, por tipo de estabelecimento;

- listagem dos estabelecimentos que foram objeto de algum procedimento;

- número de estabelecimentos inspecionados, por tipo de estabelecimento e por origem da demanda;

- total de procedimentos, por tipo e por profissional;

- relação dos estabelecimentos inspecionados, por cada profissional.

O cruzamento das informações dos três cadastros - conformando um verdadeiro sistema de informações - permite, de fato, conhecer o universo de ação, os recursos existentes e o que é feito. As possibilidades são amplas, como se pode ver no Quadro 7.

Quadro 7 Cruzamento das informação entre os cadastros dos componentes dos SIVISA

\section{Cruzamento}

Banco de estabelecimentos

$x$

Banco da equipe
A informação obtida propicia:

Conhecer o universo de atuação da Vigilância Sanitária, tornando possivel a determinação da equipe minima; verificar capacidade operacional (recursos humanos e equipamentos) para realizar os procedimentos de acordo com as caracteristicas dos estabelecimentos;

verificar o credenciamento do profissional que realizou o procedimento; verificar a atividade profissional do executor; verificar a compatibilidade entre 0 procedimento realizado e a condição de gestão do municipio ou Estado;
Banco da produção $x$

Banco de estabelecimentos verificar cadastramento do estabelecimento que foi alvo da ação; verificar complexidade do procedimento, relacionando-a ao tipo/atividade econômica do estabelecimento. 


\section{Referências bibliográficas}

BARRETO, A.A.A., 1994. Questão da Informação. São Paulo: Revista São Paulo em Perspectiva, 8 (4), p.3-8.

BRANCO, M.A.F., 1996. Sistema de Informação em Saúde no Nível Local. Rio de Janeiro: Cadernos de Saúde Pública. 12(2), 267-270, pp.330-337.

CARVALHO, D.M., 1997. Grandes Sistemas Nacionais de Informação em Saúde: Revisão e Discussão da Situação Atual. Brasília: Fundação Nacional de Saúde. Informe Epidemiológico do SUS, VI (4), p. 7-46.

McGEE, J.; PRUSAK, L., 1994. Gerenciamento Estratégico da Informação. Rio de Janeiro: Campus, p 244.

MORAES, I.H.S., 1994. Informaçōes em Saúde: da Prática Fragmentada ao Exercício da Cidadania. Rio de Janeiro: HUCITEC/ABRASCO, p 172. 


\section{Avaliação da qualidade}

\section{Conteúdo}

Qualidade e avaliação em saúde: conceitos básicos. Tipos de avaliação da qualidade dos serviços e da tecnologia. O modelo de Donabedian. Controle de qualidade laboratorial. Boas práticas de produção e de análise.

A leitura deve permitir:

- Discutir o conceito de qualidade no campo da saúde, e em relação aos objetos da ação em Vigilância Sanitária. Distinguir as diferenças conceituais entre avaliação, garantia e controle de qualidade.

- Conhecer os principais métodos e técnicas de avaliação, garantia e controle da qualidade aplicados aos programas, serviços, procedimentos e produtos empregados no campo da saúde, e capazes de sustentar as ações de Vigilância.

- Conhecer o modelo de Donabedian, descrever os sete pilares, o enfoque de avaliação e os conceitos operacionais de indicador e de padrão. 



\section{Avaliação da qualidade em saúde}

Margareth Crisóstomo Portela

\section{Introdução}

A Avaliação em Saúde produz informações quanto a adequação, efeitos e custos associados ao uso de tecnologias, programas ou serviços de saúde. $\mathrm{E}$, assim, pode subsidiar a tomada de decisão em relação às práticas de saúde e ao estabelecimento de políticas concernentes ao setor. A Avaliação em Saúde pressupõe:

- a seleção de problemas relevantes, e sensíveis, a medidas de ação viáveis nos níveis técnico, político e econômico;

- a medição de atributos pertinentes a tecnologias, programas ou serviços de saúde, que se constituem em alternativas para a solução, ou a minimização, de problemas, em uma população;

- o julgamento e a comparação do comportamento desses atributos, como critérios de apreciação da adequação, dos benefícios, dos efeitos adversos e dos custos associados às alternativas, levando-se em conta a população de referência e o conhecimento, ou o arsenal tecnológico existente/disponivel; e

- a alimentação dos processos de análise e de formulação de condutas, ou recomendações, para ação gerencial ou governamental.

\section{Indicador, padrão e referente}

A Avaliação em Saúde envolve a seleção de critérios para julgar e comparar adequação, benefícios, efeitos adversos e custos de tecnologias, serviços ou programas de saúde; esses critérios constituem-se em indicadores de qualidade em saúde (Donabedian, 1980b; Reis, 1995).

tecnologias, programas ou serviços de saúde 
Em outras palavras, indicadores de qualidade em saúde correspondem a critérios para a avaliação da qualidade da assistência à saúde a uma população, seja em termos de procedimentos específicos ou de uma rede de serviços. São exemplos de indicadores de qualidade em saúde: o número de profissionais de saúde a atender uma população; as condições de armazenamento de medicamentos em uma farmácia; o percentual de prescrições realizadas em um serviço de saúde e atendidas pela farmácia do próprio serviço; a sensibilidade (probabilidade do exame diagnosticar a doença se o indivíduo tem a doença) e a especificidade (probabilidade do exame ser negativo se o indivíduo não tem a doença) de um exame diagnóstico (Eddy, 1993); a taxa de infecção hospitalar em um hospital; e a existência de um sistema de referência e contra-referência de pacientes dentro de uma rede de serviços de saúde.

Um outro conceito de grande importância na Avaliação em Saúde é o de padrão. Esse conceito se refere a um valor especificado para distinguir a qualidade de práticas, ou de serviços de saúde, em aceitável ou não, à luz de um certo indicador (Donabedian, 1980b; Reis, 1995).

Consideremos um exame laboratorial que, se realizado em condições adequadas, tem uma chance de resultar em erro de $1 \%$ dos casos (falsos-positivos e falsos-negativos). Qualquer laboratório, assim, teria, na realização de um grande número desses exames, uma margem de $1 \%$ de erro. Suponhamos, então, que, levando-se em conta algum grau de variabilidade aleatória dos resultados, se estabelecesse como padrão de qualidade para a realização do exame a ocorrência de 1,05\% falsos positivos e negativos. No que diz respeito ao indicador "proporção de diagnósticos errados", seriam passíveis de investigação aqueles laboratórios que apresentassem valores superiores ao padrão estabelecido, sendo mais problemáticos, em potencial, aqueles que apresentassem valores, para o indicador, muito superiores ao padrão de $1,05 \%$.

$\mathrm{O}$ exemplo remete a dois pontos importantes. O primeiro refere-se à noção de que só é possível inferir conclusões acerca da qualidade de serviços ou tecnologias em saúde com base em um grupo de observações; ocorrências individuais de eventos adversos podem representar um sinal de alerta, mas não devem ser vistas, necessariamente, como reflexos de má qualidade. O registro de uma morte materna em uma maternidade de perfil médio no período de um ano, ainda que mereça investigação das suas causas, pode representar uma fatalidade, sem ser sinal de precariedade na assistência; cinco mortes maternas no mesmo período, entretanto, constituem-se em indício mais forte de má qualidade. O conceito de evento sentinela, trazido da epidemiologia, diz respeito a observar esses eventos como um alerta para a possibilidade de deficiência na qualidade da atenção. Visto de uma forma ampla, esse con- 
ceito permeia a própria lógica da avaliação de qualidade. Segundo essa lógica, a observação de valores, para indicadores selecionados, destoantes do padrão esperado, não determina a deficiência na qualidade da atenção à saúde, mas indica, em menor ou maior grau, a possibilidade da mesma.

O segundo ponto tem a ver com o estabelecimento de padrões, ou seja, com a definição de níveis de aceitabilidade para indicadores de qualidade em saúde. Este campo tem merecido atenção de pesquisadores e profissionais de saúde, preocupados, especialmente, em identificar processos de atenção que se caracterizam como boa prática. Algumas referências podem ser apontadas:

1) A evidência científica da associação entre condições da estrutura e do processo de atenção e resultados na saúde do indivíduo ou da população;

2) Os valores médios, ou medianos, de indicadores de interesse em centros de referência internacionais ou nacionais;

3) Os melhores resultados em realidade de perfil semelhante.

De 1 para 3 há uma perda na qualidade da informação base para o estabelecimento de padrões, mas também um aumento de flexibilidade, que pode permitir alguma comparação de indicadores no nível local.

Vale ainda lembrar que se usam padrões para se estabelecer processos de certificação e acreditação de serviços de saúde e programas de garantia de qualidade.

Se o indicador é um critério, e o padrão é um valor representativo de qualidade para o indicador, os significados de ambos dependem de características do problema e da população-alvo das práticas, ou dos serviços de saúde, sob avaliação; assim, chega-se ao conceito de referente.

A definição do referente, em um processo de Avaliação em Saúde, garante a construção de categorias homogêneas e replicáveis, com base nas quais tecnologias, ou serviços de saúde, podem ser comparados, em locais e momentos diversos (Donabedian, 1980b, Reis, 1995). Essas categorias costumam ser estabelecidas segundo características diagnósticas/clínicas, podendo também levar em conta características demográficas, geográficas ou culturais da população. O uso de um referente reduz o grau de incerteza na consideração de indicadores e padrões de qualidade da assistência. E esse conceito deve estar presente na concepção de indicadores e padrões, e na medição e na análise dos mesmos.

Um bom exemplo da necessidade de se considerar um referente é o uso do indicador "mortalidade hospitalar" para avaliar a qualidade da assistência hospitalar. É possível que o indicador seja inadequado na comparação de hospitais onde a clientela assistida tem um risco de mor-

\section{certificação} e acreditação de serviços 
rer, durante a internação, próximo de zero (ex: hospitais psiquiátricos ou clínicas de cirurgia estética). Em casos onde o indicador é adequado, entretanto, é fundamental considerar-se o perfil da clientela assistida. É preciso diferenciar uma taxa de mortalidade hospitalar alta, devida à qualidade da assistência, de outra, inerente ao perfil de gravidade da clientela. O referente serve, portanto, de contexto da avaliação e de garantia de coisas diferentes não serem tratadas como iguais. A taxa de mortalidade esperada em um hospital especializado no tratamento de câncer é muito mais elevada do que a esperada em um hospital geral, por sua vez maior do que a esperada em uma maternidade. Mortes neonatais resultantes de gestação de alto risco têm um significado diferente de mortes neonatais resultantes de gestação sem risco, e parto a termo.

Os conceitos de indicador, padrão e referente são aplicados na avaliação dos três componentes, segundo Donabedian, da produção de serviços de saúde: a estrutura, o processo e os resultados.

\section{Avaliação de estrutura, processo e resultados da assistência à saúde}

O componente "estrutura" abrange os recursos humanos, físicos e financeiros utilizados na provisão de cuidados de saúde, bem como os arranjos organizacionais e os mecanismos de financiamento destes recursos. O componente "processo" refere-se às atividades que constituem a atenção à saúde, e envolvem a interação de profissionais de saúde e população assistida. O componente "resultados", diz respeito às mudanças, no estado de saúde da população, promovidas pelos cuidados recebidos (Donabedian, 1980a; Vuori, 1991).

$\mathrm{Na}$ avaliação de práticas e serviços de saúde pressupõe-se que uma estrutura adequada propicia um bom processo de assistência à saúde. $\mathrm{E}$ que este processo, por sua vez, leva a mudanças favoráveis no nível de saúde da população. Esta pressuposição, entretanto, não deve ignorar a inexistência de um vínculo causal, obrigatório, entre os três componentes (estrutura, processo e resultados). Interessam, em especial, os resultados produzidos sobre a saúde da população-alvo, mas é fundamental poder atribuir esses resultados ao processo de assistência. O conhecimento do processo de atenção à saúde ganha importância sempre que o estabelecimento de elos causais entre seus elementos e os resultados, favoráveis, ou desfavoráveis, seja possível, com base em evidência científica.

A avaliação de estrutura é a que menos informação oferece sobre a qualidade da atenção à saúde. Mas pode ser importante para complementar avaliações do processo e dos resultados, ou, em alguns casos, 
ser a única possível. Ao realizar somente a avaliação de estrutura, porém, o avaliador deve ter o cuidado de evitar confundir a capacidade de um serviço gerar cuidados de boa qualidade com a qualidade de atenção em si mesma.

Indicadores e padrões de qualidade da estrutura de serviços de saúde costumam ser utilizados para o credenciamento de unidades de saúde. Alguns exemplos são: existência ou não de um serviço de vigilância epidemiológica em uma unidade de saúde; condições de armazenamento de medicamentos na farmácia de um centro de saúde ou hospital; número de profissionais de saúde - por categoria - envolvidos na assistência a uma população em relação ao número de pessoas assistidas; e número de leitos disponíveis, por especialidade, em um certo hospital ou área geográfica.

A avaliação de processo sedimenta-se na idéia de que a probabilidade de ocorrência de resultados favoráveis cresce quando tecnologias em saúde (procedimentos médicos e cirúrgicos, equipamentos, medicamentos, sistemas organizacionais e de suporte à provisão de cuidados de saúde, etc.) são aplicadas corretamente, à luz do conhecimento existente. Esta ótica, conservadora em relação ao conhecimento corrente, propicia, no entanto, elementos operacionais para a apreciação da qualidade de práticas e serviços de saúde. E permite, também, a correção de problemas, praticamente no tempo real.

A existência de relações causais, bem estabelecidas, entre processo de atenção à saúde e resultados sobre a saúde da população fortalece a abordagem de processo na avaliação de qualidade; a busca dessas relações constitui um campo de forte interesse para pesquisadores na área da Avaliação em Saúde. E com base nas mesmas, indicadores e padrões de processo podem ser definidos e utilizados, visando a garantia de resultados. $\mathrm{Na}$ ausência de evidência científica a consolidar o elo causal entre processo e resultados, entretanto, vale a pena considerar a opinião de especialistas quanto ao que eles julgam ser práticas de boa qualidade. O desenvolvimento de critérios de boa assistência tem, no mínimo, o mérito de fazer com que os prestadores de serviços de saúde entendam melhor suas formas de trabalho e desenvolvam abordagens mais efetivas e racionais.

Além de estarem incluídos nos protocolos de certificação e de acreditação de unidades de saúde, os indicadores e padrões de processo constituem-se em elementos centrais de sistemas de auditoria de práticas e serviços de saúde. Em especial, de auditoria médica. Além disso, o enfoque no processo de assistência à saúde permeia os estudos de utilização de serviços de saúde. Esses estudos buscam identificar e explicar variações no uso de recursos de saúde, inclusive tecnológicos, na indicadores da estrutura

tecnologias em saúde

auditoria

estudos de utilização de serviços de saúde 
indicadores de resultados atenção a um problema e identificar e explicar ocorrências de padrões de atendimento desviantes.

A avaliação de resultados é, enfim, aquela que realmente capta mudanças no estado de saúde da população. Na medida em que o objetivo da atenção a uma população é a melhoria da sua condição de saú. de, a avaliação de resultados fundamenta-se no propósito de medir o cumprimento desse objetivo. Para tanto, há duas dificuldades:

1) A medição do resultado em si, visto existirem situações onde respostas ao uso de tecnologias, ou serviços de saúde, somente se observam após um longo período, ou onde não há clareza quanto às respostas mais relevantes; e

2) A atribuição do resultado ao cuidado à saúde em questão. Além disso, a avaliação de resultados é limitada no que diz respeito à indicação do que se deve fazer face a achados desfavoráveis.

Os efeitos produzidos por cuidados de saúde na população-alvo são, portanto, idealmente rastreados por indicadores de resultado. Esses indicadores, por sua vez, ao apontarem áreas potenciais de problema, devem ser complementados por indicadores de estrutura e de processo, com vistas à identificação de fatores que possam explicar a existência dessas áreas. A atribuição de um efeito a causas específicas será tanto mais válida quanto mais evidência houver, segundo o conhecimento existente, da observação de relação causal entre causas e efeito considerados.

$\mathrm{Na}$ inviabilidade do uso de indicadores de resultado, os de processo são os mais úteis para a predição do grau de cumprimento dos objetivos de cuidados de saúde, pois oferecem mais informação. Em simetria ao caso anterior, quanto mais determinantes forem os elementos contemplados por indicadores de processo, tanto maior será a capacidade do avaliador atribuir a esses elementos os resultados esperados.

Em termos práticos, o processo de prestação de cuidados de saúde é o objeto central da avaliação desses cuidados. A avaliação, entretanto, guia-se, prioritariamente, pelo julgamento dos resultados observados. Mas pode também orientar-se pelo julgamento de características desse processo, características com poder de predição de resultados. Indicadores de processo e de resultados devem ser complementares, situando-se o cerne da avaliação nas relações entre os mesmos.

Entre os indicadores de resultados incluem-se aqueles referentes à mortalidade, à morbidade, à incapacitação e ao desconforto. Alguns exemplos são a proporção de internações resultantes em morte em um hospital; os anos de sobrevida ou, anos de sobrevida ajustados, por qualidade, relacionados ao uso de uma tecnologia médica; casos de uma doença preveníveis por uma certa tecnologia profilática; anos de sobre- 
vida ajustados por incapacitação; nível de ocorrência de efeitos colaterais associados ao uso de um medicamento; índice de Apgar registrado no $1^{2}$ e no $5^{2}$ minuto de vida do recém-nato; e taxa de infecção hospitalar.

Os indicadores de resultados podem constituir-se em medida direta, ou indireta, das conseqüências do uso de intervenções em saúde. A redução na transmissão vertical do vírus da AIDS (HIV), por exemplo, é uma medida direta do efeito da administração correta de AZT a gestantes HIV-positivas e aos seus bebês. Por outro lado, a carga viral ou o nível de células CD4 + de um paciente infectado pelo HIV é uma medida indireta do risco de ocorrência de doenças oportunísticas, a ser diminuído, ou não, pelo uso de medicamentos. Também são medidas indiretas de efeitos na saúde da população as medidas próprias de tecnologias diagnósticas; a sensibilidade, a especificidade, e outras medidas utilizadas na avaliação de um exame laboratorial, ou de imagem, por exemplo, falam das chances de um indivíduo receber tratamento adequado, mas não falam de mudanças no estado de saúde desse indivíduo.

\section{Qualidade em saúde}

O conceito de qualidade aplicado a cuidados à saúde é, na prática, abordado em termos de um conjunto de atributos desejáveis. Donabedian (1990) propõe sete atributos, por ele chamados de pilares da qualidade: eficácia, efetividade, eficiência, otimização, aceitabilidade, legitimidade e eqüidade. Desses atributos, três apresentam interesse especial para a rotina de trabalho nos laboratórios de controle de qualidade em saúde: eficácia, efetividade e eficiência.

A eficácia de uma tecnologia em saúde é medida pelo benefício produzido por sua aplicação, sob condições ideais, aos problemas de indivíduos de uma população (Panerai \& Mohr, 1989). Sua avaliação dáse através de estudos clínicos controlados. E, na consideração de estratégias alternativas de cuidados à saúde, o limite máximo de benefício, na atenção a um certo problema, corresponde àquele atingido pela estratégia mais eficaz.

O conhecimento da eficácia de uma tecnologia em saúde diz respeito, portanto, à melhoria possível sobre um problema específico de saúde, em uma população definida, à luz do conhecimento existente. A melhoria observada no estado de saúde de uma população pela aplicação de uma tecnologia a um problema de saúde, em condições reais, corresponde ao conceito de efetividade (Panerai \& Mohr, 1989).

Operacionalmente, medidas de eficácia e de efetividade são fornecidas pelos mesmos indicadores de resultados, selecionados conforme sete pilares

da qualidade

eficácia

efetividade 
os objetivos das tecnologias avaliadas e segundo a população. A efetividade é um atributo de maior interesse na avaliação da provisão diária de cuidados de saúde, servindo a eficácia como um parâmetro para consideração do quanto os resultados observados se distanciam dos resultados idealmente esperados. Mas uma certa alternativa tecnológica $\mathrm{A}_{\text {, }}$ menos eficaz que $B$, pode estar associada a uma efetividade maior em um certo contexto (condições físicas de implementação, características dos profissionais de saúde envolvidos, grau de dificuldade para a adesão da. população tratada, etc), e ser, assim, mais indicada.

Eficiência é uma medida que contrapõe recursos utilizados e resultados obtidos, no uso de uma tecnologia ou serviço de saúde. A eficiência, é dada por análises de custo-benefício, custo-efetividade e custoutilidade, definidas no âmbito da avaliação econômica, através da comparação de duas alternativas tecnológicas empregadas na solução, ou na redução, de um problema de saúde, em uma população (Drummond et al., 1997). Nos três casos, a comparação de uma alternativa que representa a prática prevalente com outra menos empregada, dá-se pela análise do custo e dos benefícios adicionais dessa alternativa; mas é preciso avaliar se os custos adicionais justificam os benefícios adicionais.

$\mathrm{Na}$ análise de custo-benefício, custos e benefícios são medidos em unidade monetária. A grande crítica a este tipo de análise, na área da saúde, é a dificuldade em se atribuir valores monetários a resultados da provisão de cuidados de saúde (aumento na expectativa de vida, prevenção de doenças, diminuição do nível de incapacitação, etc).

A análise de custo-efetividade considera custos em unidade monetária, e benefícios em termos de medidas de efetividade, de indicadores de resultado. Supondo-se a comparação de uma intervenção $A \operatorname{com}$ outra $B$, a relação de custo-efetividade incremental é dada por: (CA-CB)/(EA-EB).

Pode-se, por exemplo, avaliar o custo adicional do uso de $A$, como alternativa ao uso de B, por ano de sobrevida a mais resultante, ou por caso de doença a mais prevenido.

A análise de custo-utilidade é uma extensão do custo-efetividade para casos onde a medida de efetividade é anos de sobrevida. Diferencia-se na ponderação, no ajuste, de anos de sobrevida por um fator, que expressa a qualidade dessa sobrevida. Este fator comumente varia entre 0 , para morte, e 1, para vida em condições plenas. A medida mais clássica em análises de custo-utilidade diz respeito ao custo adicional por ano de sobrevida, ajustado por qualidade $(Q A L Y$ - quality-adjusted life year) adicional. 


\section{Controle de qualidade em saúde: perspectivas da garantia de qualidade e da melhoria contínua de qualidade}

O controle de qualidade em saúde tem como objetivo verificar a aderência dos indicadores de qualidade aos padrões definidos e corrigir desvios. Utiliza-se-o para manter, ou mudar, uma situação diagnosticada pelo processo de avaliação (Inojosa, 1996). Neste sentido, o controle de qualidade decorre da avaliação, e busca implementar medidas de melhoria da qualidade de práticas e serviços de saúde, ou de prevenção de problemas potenciais.

O controle em qualidade em saúde deve centrar-se nas relações entre processo e resultados da prestação de cuidados de saúde, mas não deve ignorar aspectos relevantes da estrutura existente. E pode constituir-se sob a perspectiva da garantia de qualidade, ou da melhoria contínua de qualidade (MCQ).

A abordagem da garantia de qualidade se concentra em elementos relevantes de cada um dos processos que se deseja monitorar em uma organização de atenção à saúde, satisfazendo-se com a observância dos padrões definidos para os indicadores considerados. Se, por um lado, pode fazer com que metas de qualidade sejam distantes, em contextos onde a qualidade dos cuidados de saúde é precária, por outro, é conservadora para contextos onde o nível de qualidade desejado é atingido.

Azevedo (1993) usa como exemplo do enfoque de garantia de qualidade o controle de infecção cirúrgica em um hospital brasileiro, com base no indicador "taxa de infecções em cirurgias limpas". Assumindo uma taxa de $3 \%$ como aceitável, na observância desse padrão, a gerência de qualidade do hospital dar-se-ia por satisfeita, passaria a preocupar-se em manter esse nível, e iria dedicar-se a um ponto do processo que ainda carecesse de aprimoramento.

A perspectiva da MCQ, por sua vez, envolve toda a estrutura de uma organização de saúde, e considera flexíveis o nível de qualidade a se atingir e os próprios indicadores de qualidade. A idéia de aprimoramento contínuo não impõe limites à qualidade a ser atingida. Além disso, na medida que níveis melhores de qualidade são atingidos, indicadores mais sensíveis às novas melhorias podem tornar-se necessários. A MCQ é um esforço contínuo de prover cuidados que atendam, ou excedam, as expectativas da clientela (Shortell et al, 1995a).

Cinco princípios norteiam a MCQ:

1) O foco nos processos e sistemas organizacionais, e não nos indivíduos, como causas de deficiência na qualidade;

2) O uso de uma abordagem de solução de problemas baseada em análise estatística; 
situaçöes traçadoras
3) A composição de grupos de trabalho envolvendo profissionais com atribuições diversas;

4) O fortalecimento de funcionários da organização no sentido de identificar problemas e oportunidades para a melhoria dos cuidados e de tomar as decisões necessárias; e

5) A ênfase na clientela e nos profissionais da organização (Shortell et al, 1995b).

Ainda que o princípio da garantia de qualidade oriente as práticas de auditoria, certificação/acreditação da qualidade, e mesmo da própria Vigilância em Saúde, existem desafios no sentido de uma maior incorporação, por provedores de cuidados de saúde, da lógica da MCQ. A complexidade desta última abordagem, entretanto, pode apontar a necessidade de métodos de controle capazes de captar o conjunto de processos de produção de cuidados de saúde, em uma organização, através de alguns elementos, ou de processos específicos. Azevedo (1993) refere-se a esses elementos ou processos específicos como situações traçadoras, situações que podem corresponder a diagnósticos, intercorrências ou procedimentos.

De modo geral, o controle de qualidade envolve a seleção aleatória de produtos, casos ou situações observados no sistema de produção de cuidados de saúde. E, assim, permite a identificação e a análise de problemas que acometem todo o sistema, a um custo factível.

\section{Referências bibliográficas}

AZEVEDO, A.C., 1993. Indicadores da Qualidade e Produtividade em Serviços de Saúde. Indicadores da Qualidade e Produtividade, 1:49-54.

DONABEDIAN, A., 1980a. The Definition of Quality and Approaches to its Assessment. Ann Arbor, Michigan: Health Administration Press. (Explorations in Quality Assessment and Monitoring, v. I).

DONABEDIAN, A., 1980b. The Criteria and Standards of Quality. Ann Arbor, Michigan: Health Administration Press. (Explorations in Quality Assessment and Monitoring, v. II).

DONABEDIAN, A.,1990. The Seven Pillars of Quality. Arch Pathol Lab Med, 114:1115-1119. DRUMMOND, M.F.; O'BRIEN, B.; STODDART, G.L.; TORRANCE, G.W., 1997. Methods for the Economic Evaluation of Health Care Programmes. Oxford: Oxford University Press, Second Edition.

EDDY, D.M., 1992. Assessing Health Practices \& Designing Practice Policies: The Explicit Approach. Philadelphia, PA: American College of Physicians.

INOJOSA, R.M., 1996. Avaliação e Controle do SUS: Mudam-se as Práticas? Cadernos FUNDAP, 19:88-97. 
PANERAI, R.B.; MOHR, J.P., 1989. Health Technology Assessment: Methodologies for Developing Countries. Washington, DC: Pan American Health Organization.

REIS, L.G.C., 1995. Introdução à Avaliação da Qualidade em Serviços de Saúde. In: Avaliação da Qualidade do Uso da Ocitocina no Trabalho de Parto em Maternidades Públicas do Município do Rio de Janeiro. Rio de Janeiro: ENSP/FIOCRUZ. (Tese de Mestrado).

SHORTELL, S.M.; LEVIN, D.Z.; O'BRIEN. J.L; HUGHES, E.F.X., 1995a. Assessing the Evidence on CQI: Is the Glass Half Empty or Half Full? Hospital \& Health Services Administration, 40: 4-24.

SHORTELL, S.M.; O'BRIEN, J.L.; CARMAN, J.M.; FOSTER, R.W.; HUGHES, E.F.X.; BOERSTLER, H.; O'CONNOR, E.J., 1995b. Assessing the impact of Continuous Quality Improvement/Total Quality Manegement: Concept versus Implementation. Health Services Research, 30: 377-401.

VUORI, H., 1991. A Qualidade da Saúde. Divulgação em Saúde para Debate. 



\section{O Laboratório Oficial na avaliação analítica}

Ana Célia Pessoa da Silva

\section{Antecedentes}

Especificar as matérias primas a as técnicas utilizadas na preparação de medicamentos é prática tão antiga como a própria história do uso de produtos com fins terapêuticos.

O conhecimento acumulado pelos povos primitivos propiciou a identificação minuciosa de espécies e gêneros vegetais considerados úteis ao homem, assim como das partes das plantas que mais se adequavam ao uso. Esse legado de conhecimentos se transmitiu de geração a geração e constituiu, durante séculos, a base terapêutica da humanidade.

Após a identificação, dos vegetais vieram as técnicas de extrair sucos, secar folhas e raízes e triturar sementes; como forma de conservação dos mesmos. Assim se iniciou a configuração de um corpo teórico e prático de conhecimento, num processo longo, no qual a intuição, aliada ao ensaio, iria, lentamente, converter a experiência em saber e depois em memória coletiva. E esse conhecimento, sempre repassado às gerações seguintes, veio a constituir a medicina do homem primitivo.

Com o advento da escrita, as farmacopéias - livros que descreviam as matérias-primas, as fórmulas, as indicações e as posologias das drogas - passara:n a ser o cofre desse saber, e ganharam autoridade, embora de uso não o'brigatório.

No Brasil, até a Independência, em 1822, usava-se a farmacopéia portuguesa de 1794; a partir dessa data, apesar da nossa emancipação política, continuamos a seguí-la. Mas a influência do positivismo levounos a adotar a farmacopéia francesa a partir de 1837. A obrigatoriedade legal do uso da farmacopéia, porém, só se estabeleceu através do Decreto 828 , de 29 de setembro de 1851 . O artigo 45 desse decreto estabelecia

farmacopéia 
Portaria ne 1.812, de 1907, Instituto de Patologia Experimental de Manguinhos

Decreto ne 17.509, de 1926, Farmacopéia Brasileira que "... para a preparação dos remedios officinaes seguir-se-á a pharmacopeia franceza, até que esteja composta uma pharmacopeia brasiliense..."

Os primeiros laboratórios de apoio à fiscalização surgiram no final do século passado. A abordagem laboratorial refletia a percepção de qualidade da época, e se restringia à verificação da identidade e da integridade dos produtos. Neste período, praticamente todas as substâncias químicas conhecidas tinham emprego terapêutico, além de vários vegetais. Não importava se o produto era eficaz ou seguro, embora se exigisse a exatidão da fórmula.

A Portaria ne 1.812, de 1907, criou o Instituto de Patologia Experimental de Manguinhos, com atribuições de pesquisar e produzir "soros terapêuticos e demais produtos congêneres, destinados ao tratamento e profilaxia das moléstias." E estabelecia (art. 1, parágrafo 11) "não se poderão oferecer à venda vacina e soro fabricados no estrangeiro, ou dentro do País por particulares, sem prévio exame, ensaio e laudo favorável do Instituto. A esse exame não ficarão sujeitos os soros e vacinas preparados por institutos oficiais dos Estados e Distrito Federal, salvo quando alguma ocorrência for de ordem a gerar suspeita contrária à pureza e perfeição dos ditos preparados." (Brasil, 1929)

Nesta Portaria se revela que a abordagem analítica, então proposta, demonstrava a preocupação com a conformidade do processo produtivo, com algum controle da composição e para verificar a presença de possíveis contaminantes, e com a importação.

A primeira Farmacopéia Brasileira foi aprovada pelo Decreto ne 17.509, de 1926. Esse decreto estabelecia a obrigatoriedade do uso da mesma na elaboração e no controle dos medicamentos, o que só aconteceu em 1929. O primeiro código farmacêutico editado no país classificava as drogas vegetais pelo nome científico, seguido do nome em latim da planta, e do nome da família a que pertencia a mesma; indicava a parte a ser usada, as características farmacognósticas, macroscópicas e microscópicas, ensaios de impurezas, algumas determinações de substâncias marcadoras, empregos oficinais, etc.... Esse código denota um profundo conhecimento da problemática dos fitoterápicos, e serviu, inclusive, de referência internacional.

Já as drogas de origem chimica eram apresentadas pelos vários nomes em uso na ocasião. Era possível identificar essas drogas através dos caracteres físicos e organolépticos, como aspecto, formas de cristalização, cor, cheiro, sabor, solubilidade em alguns solventes, ponto de fusão e reações características. Nossa farmacopéia seguiu as especificações de farmacopéias estrangeiras.

Nossa farmacopéia apresentava, ainda, alguns ensaios de impurezas e falsificações, processos de doseamento, formas de conservação, 
emprego terapêutico e as doses máximas permitidas, quando se tratava de medicamentos heróicos, - substâncias hoje consideradas venenos ou quando havia pequena margem de variação entre a dose terapêtica e a tóxica, e até a letal.

A evolução da produção artesanal para a escala industrial, em conjunção com processos de vigilância, possibilitou a associação de algumas tragédias ao uso de determinados produtos. Isto despertou a sociedade para a necessidade de regulamentar e controlar produtos que pudessem causar danos à saúde. Desta forma, não apenas ampliou-se o leque de produtos a serem regulamentados, mas se promoveu uma modificação radical da avaliação laboratorial em Vigilância Sanitária. Assim, a partir da década de 1950, outros produtos passaram a ser disciplinados e/ou revisados, segundo a evolução do conceito de risco. Entre estes estão os correlatos (1950); os cosméticos (1965); os dietéti$\cos (1969)$ e, mais recentemente, os saneantes (1970).

Os alimentos foram os primeiros produtos a ganharem legislação específica, revisada e atualizada em consonância com os avanços da tecnologia de produção e a incorporação de testes específicos para o controle de riscos, já reconhecidos e comprovados; foram também os primeiros a "ganharem a desconfiança" ante o surgimento de novos produtos com novos coadjuvantes. Foi assim que surgiu, por exemplo, o Decreto-Lei n 986 de 1969; acredita-se que a tragédia da talidomida tenha contribuído para tal prudência.

Com a promulgação da Lei $\mathrm{n}^{\circ} 6.360$ de 1976 , medicamentos, correlatos, cosméticos e domissanitários, passaram a ser submetidos aos mesmos preceitos, à mesma prudência presentes na legislação para os alimentos.

A Lei n 6.437 de 1977, ao configurar infração à Legislação Sanitária, reúne todos os produtos, inclusive os alimentos, sob o mesmo ordenamento jurídico. E instruiu, também, a realização de análises para avaliação laboratorial. O cerne dessa avaliação é a verificàção da conformidade do produto com as especificações contidas no registro (análise de controle), concedido pela Secretaria de Vigilância Sanitária do Ministério da Saúde, e com as normas de qualidade mínima (análise fiscal), publicadas no Diário Oficial da União (D.O.U).

A partir da promulgação da Constituição Federal, em 1988, deu-se um novo salto qualitativo e quantitativo na concepção sanitária nacional, com a constituição de um Sistema Único de Saúde - SUS, regionalizado e hierarquizado. Uma das diretrizes do SUS é dar prioridade às atividades preventivas (art. 198, inciso II da Constituição), com atribuições, entre outras, de: "controlar e fiscalizar procedimentos, produtos e substâncias de interesse para a saúde..." e "executar ações de Vigilância análise de controle e análise fiscal

Constituiçăo Federal, em 1988 
Lei ne 8.080 , sus

Lei ne 8.079, de 1990, Código de Defesa do Consumidor
Sanitária e Epidemiológicas" (art. 200, incisos I e II, respectivamente, da Constituição Federal).

O novo salto na concepção sanitária nacional pode ser melhor percebido através da definição de Vigilância Sanitária da Lei n 8.080 de 1990, que regulamenta o SUS. "Entende-se por Vigilância Sanitária um conjunto de ações capaz de eliminar, diminuir ou prevenir riscos à saúde e de intervir nos problemas sanitários decorrentes do meio ambiente, da produção e circulação de bens de serviços de interesse da saúde..." (art. 62, parágrafo 1^).

Esta definição relativiza a importância das ações pontuais historicamente desenvolvidas pela Vigilância Sanitária, sob forma de apreensões isoladas e esporádicas de produtos, para análises laboratoriais. E remete o cerne da atividade para o conjunto de ações capazes de efetivar seus objetivos, isto é, eliminar, diminuir e prevenir os riscos à saúde. O novo ordenamento para enfrentar o risco implica a revisão de todas as etapas da intervenção da Vigilância Sanitária, desde o registro até o consumo.

Graças à atribuição e à abrangência desta definição, não apenas os produtos historicamente alvos da ação de Vigilância, mas quaisquer bens de consumo, passaram a ser objeto da fiscalização, desde que, direta ou indiretamente, se relacionassem aos fatores condicionantes ou determinantes da saúde (art. 5², inciso I, da Lei ne 8.080/90).

Segundo Pilati (1995), os formuladores da Lei Orgânica da Saúde reconheceram a impossibilidade de enumerar todos os itens que apresentam riscos à saúde, assim como "...os problemas sanitários decorrentes do meio ambiente, da produção e circulação e da prestação de serviços de interesse da saúde...", e, assim, preferiram generalizar a definição de Vigilância Sanitária.

No bojo das conquistas sociais advindas da promulgação da nova Constituição Federal, surgiu o Código de Defesa do Consumidor, Lei ne 8.079, de 1990, que, entre outras determinações, busca a proteção da saúde contra os riscos do consumo de produtos considerados perigosos ou nocivos. O Código de Defesa do Consumidor externa o entendimento social de serem a qualidade e o risco responsabilidades do fabricante e/ou fornecedor.

Um outro destaque necessário é a evolução da Legislação Sanitária que, inicialmente, assumiu caráter de um estatuto criminal contra a fraude e a propaganda enganosa, e passou a ser uma estrutura legislativa cujo principal objetivo é o de prevenir riscos à saúde dos usuários (Pilati, 1995).

Mas umas questões continuam pendentes. Como criar uma estrutura para reconhecer e eliminar riscos, cada vez mais complexos, em 
uma área da tecnologia em constante expansão? Como desenvolver e instigar pesquisas de possíveis eventos danosos à saúde, muitas vezes conhecidos, mas de ação e controle incertos?

Atualmente, a necessidade da regulamentação de produtos é tida não apenas como indiscutível para a maioria dos países, mas como uma tarefa inalienável do Estado. A qualidade do produto não se restringe apenas às características intrínsecas do produto, mas é entendida como um binômio indissociável, em cuja avaliação as variáveis eficácia e segurança devem estar sempre presentes.

O controle é uma das ações identificadas como sendo capaz de eliminar, diminuir ou prevenir riscos à saúde. O termo controle não se refere apenas à controle laboratorial, mas à regulamentação, ao registro, à inspeção, ao monitoramento, etc. A coleta ou apreensão de amostras volta a ser referendada como um meio, não único, de fiscalização de produtos de interesse da saúde.

\section{Novas interfaces das instâncias da Vigilância no SUS}

Uma das principais questões a emergir das legislações supracitadas, em especial daquelas derivadas da filosofia de descentralização com integração e hierarquização do SUS, - Leis 8.080 e 8.142 , de 1990 - é a nova processualidade administrativa, em que a efetividade da ação impõe a ação conjunta de vários órgãos e agentes, preordenados juridicamente.

Esta processualidade requer um conhecimento inequívoco de como e quando proceder à apreensão, com quem se articular para a realização da mesma e, principalmente, que medidas tomar no caso de laudo condenatório. O funcionamento, a integração e as responsabilidades compartilhadas das diferentes esferas de governo precisam ser melhor compreendidas. Aqui reside a necessidade de articulação entre as estruturas de registro, de fiscalização e de avaliação laboratorial.

Isso significa dizer que é necessário consolidar a integração das atividades fiscais dos serviços estaduais e municipais com seus respectivos Laboratórios Centrais de Saúde Pública (LACEN), ou equivalentes e com a estrutura federal. E redimensionar as responsabilidades e competências desses serviços nas ações integradas de apreensão e avaliação laboratorial de produtos de interesse da Saúde Pública.

Por outro lado, esta integração deve propiciar uma permanente avaliação crítica dos instrumentos legais disponíveis, quanto às suas interpretação, suficiência e efetividade nas ações de proteção à saúde; a integração deve propiciar também a formulação e o encaminhamento nova processualidade administrativa

integração das atividades fiscais 
avaliação dos instrumentos legais de pareceres, a serem modificados, ou atualizados, quando se mostrarem insuficientes. A avaliação crítica dos instrumentos legais faz-se necessária porque:

1) É preciso apreender os aspectos de Saúde Pública incluídos em cada uma da proposições legais. A interpretação equivocada dos mesmos não apenas abre espaço para o questionamento jurídico, como provoca conflito entre os órgãos envolvidos, além de diluir o objetivo que se almeja alcançar.

2) A velocidade da introdução de novos produtos, novos coadjuvantes ou novas tecnologias supera os conhecimentos acumulados e consolidados em atos sanitários. Desta forma, novas fontes de agravos à saúde precisam ser monitoradas, e requerem normas específicas. A formulação destas normas só será possível se houver interação entre o agente identificador do agravo e o laboratório, que buscará a comprovação e a elucidação das causas do agravo.

3) As disposições legais, relativas a um mesmo assunto, emanam de diferentes órgãos e, por vezes, são regulamentadas, revisadas, modificadas ou substituídas, em virtude de contextos político-econômicos e/ou técnico-científicos distintos. Em conseqüência, surgem, com freqüência, contradições, omissões e/ou ambigüidades entre as normas, o que leva à dúvida do agente fiscal sobre qual legislação deve seguir.

$\mathrm{Na}$ Vigilância Sanitária dos alimentos, por exemplo, aplica-se a análise de controle quando se deveria utilizar a análise fiscal; os riscos dos alimentos transgênicos ainda não foram devidamente elucidados; e não há uma divisão, clara das fronteiras de atuação dos Ministérios da Saúde e da Agricultura na regulamentação deste produto. A complexidade aumenta quando existe necessidade de harmonização de normas de distintos países, como acontece no âmbito do Mercosul.

\section{Modalidades de análises}

A função principal das análises previstas em lei é fornecer subsídios aos órgãos fiscalizadores, e completar o conjunto de ações capazes de eliminar, diminuir ou prevenir riscos à saúde.

Como mais um elemento do conjunto de ações, a avaliação laboratorial deverá confirmar suspeitas, ou dirimir dúvidas, da fiscalização, quanto à qualidade mínima do produto, ou da matéria prima, estabelecida em lei. Não é função do laboratório, por exemplo, substituir o fabricante no fornecimento de informações científicas sobre a qualidade de produto, quando requisitadas pelas autoridades competentes, nem tampouco substituir uma inspeção sanitária de um processo pro- 
dutivo, ou do transporte, ou do armazenamento, etc. Pelo contrário, as análises previstas na legislação serão, sempre, um complemento à ação de fiscalização.

Tanto é assim que, além de estabelecer e definir as modalidades de análises, a legislação determina o exato momento de aplicação das mesmas, como proceder à coleta de amostras, como realizar a análise e o que fazer, caso a avaliação analítica seja condenatória.

São três as modalidades de análise previstas em lei: análise prévia, análise de controle e análise fiscal. Cada uma dessas análises está sempre associada a um momento do ciclo da fiscalização. A primeira avalia a eficácia e a segurança do produto, e se dá no momento da avaliação da concessão do registro; a segunda, se refere à avaliação da capacidade de produzir, de acordo com os termos concedidos no registro; a terceira, avaliará a capacidade de se seguir produzindo, conforme o estabelecido nos termos do registro, durante toda a vida útil do produto.

A legislação reproduz o entendimento de ter cada uma das modalidades objetivos específicos, associados a determinados riscos que se pretende controlar. Dimensiona, também, o grau de implicação, para a Saúde Pública, de cada irregularidade detectada e, por isso, estabelece medidas punitivas. Entende também que cada uma das análises deverá prever formas diferenciadas de eliminar o risco.

\section{Análise prévia}

\section{Definição}

Não existe uma definição desta modalidade de análise no DecretoLei $986 / 69$ e nas Leis $6.360 / 76$ e $6.437 / 77$, embora a mesma seja nominalmente citada no corpo dos dois primeiros textos legais, como veremos a seguir.

A única definição de análise prévia é estabelecida pelo art. 32 , inciso XXIX do Decreto 79.094 de 1977, que regulamenta a Lei 6.360/76, como "... aquela efetuada em determinados produtos sob o regime de Vigilância Sanitária, a fim de se verificar se os mesmos podem ser objeto de registro."

\section{Outras disposições legais}

O art. 9e do Decreto-Lei no 986/69, ao regulamentar o registro e o controle dos alimentos, estabelece: "o registo de aditivos intencionais, de embalagens, equipamentos e utensílios elaborados e/ou revestidos modalidades de análise previstas em lei 
internamente de substâncias resinosas e poliméricas e de coadjuvantes tecnológicos da fabricação que tenham sido declarados obrigatórios, será sempre precedido de análise prévia.

Parágrafo único: o laudo de análise será encaminhado ao órgão competente, que expedirá o respectivo certificado de registro."

Já na Lei ne 6.360/76, a análise prévia é nominalmente citada no art. 12 , inciso 5 , que a submete ao pagamento de preços públicos. No art. 16, inciso IV e V da mesma Lei, não se a nomina mas se assegura seu princípio, quando se sujeita a concessão de registro de medicamentos, entre outros requisitos, a:

-IV - "Apresentação, quando solicitada, de amostras para análise e experiências que sejam julgadas necessárias pelos órgãos competentes do Ministério da Saúde."

-V - "Quando houver substância nova na composição do medicamento, entrega de amostra acompanhada dos dados químicos e físicoquímicos que a identifiquem."

O art. 17 do Decreto 79.094/77, estabelece: "o registro dos produtos submetidos ao sistema de Vigilância Sanitária fica sujeito à observância dos seguintes requisitos:

-IX - Quando o produto depender de análise prévia, que esta comprove as condições sanitárias indispensáveis à sua utilização."

Quanto aos cosméticos, o art. 27 da Lei 6.360/76 condiciona a concessão de registro à satisfação de exigências, como o enquadramento dos seus componentes à relação de substâncias declaradas inócuas, elaborada e publicada pelo Ministério da Saúde. Caso contrário, o inciso II do mesmo artigo determina:

- II - "Não se enquadrando na relação referida... terem reconhecida a inocuidade das respectivas fórmulas, em pareceres conclusivos emitidos pelos órgãos competentes, de análise e técnico, do Ministério da Saúde."

\section{Interpretação e comentários}

A análise do conjunto das disposições sobre a análise prévia, revela que além de ter seu momento bem definido - durante o processo de avaliação da concessão de registro - a mesma tem uma condicionante: cabe à autoridade avaliadora do pedido de registro julgar a necessidade, ou não, de a solicitar, para a tomada de decisão.

Como o decreto não pode contrariar a lei que ele regulamenta, não se aplica a realização de análise prévia, por exemplo, nos alimentos, salvo os casos dispostos no art. 9e do Decreto-Lei 986/69; o mesmo vale para os cosméticos, segundo o artigo 27 da Lei 6.360/76. 
Do ponto de vista da Saúde Pública, existem algumas contradições e questionamentos quanto à interpretação e à prática desta modalidade de análise. Assim, por exemplo, a Legislação condiciona a concessão do registro ao reconhecimento de informes cientificamente válidos, apresentados pelos interessados (art. 19 do Decreto 79.094/77). Mas, neste aspecto, é importante considerar o que são informes cientificamente válidos. Como atualmente é possível encontrar, na literatura científica, trabalhos com conclusões antagônicas, torna-se necessária uma avaliação criteriosa dos informes apresentados e dos métodos utilizados na obtenção dos mesmos, e de suas conclusões. Sendo assim, estas avaliações deveriam ser realizadas por equipes multidisciplinares e especializadas, e os laboratórios oficiais poderiam auxiliar na verificação da validade dos testes apresentados.

A realização de um estudo de estabilidade, por exemplo, principalmente em um país como o nosso, de vários climas, é fundamental para a determinação não apenas dos prazos de validade, como de outros parâmetros (composição, produtos de degradação, metodologia analítica, embalagem, condiçōes de armazenagem, etc). Em geral, um estudo dessa natureza é demorado mas, em contrapartida, um especialista da área em alguns dias poderá dizer se os dados apresentados são pertinentes e suficientes, ou não.

Ao não detalhar os procedimentos para a coleta e envio das amostras destinadas à realização do estudo, nem a metodologia analítica a ser utilizada, a legislação pretendeu deixar aberta a possibilidade de se averiguar qualquer aspecto que a autoridade sanitária julgasse necessário à avaliação da concessão. Ou seja, já se conheciam as incertezas dos "informes cientificamente válidos", assim como já se conheciam determinadas fontes de riscos, como no caso dos alimentos e cosméticos.

Desta forma, o agente avaliador do registro poderá, a qualquer momento consultar laboratórios de referências, do Ministério da Saúde, no sentido de elucidar dúvidas existentes. Também está claro que a consulta não será, necessariamente, um laudo analítico. A solução da dúvida poderá ser um "parecer conclusivo emitido pelos órgãos competentes, de análise e técnico, do Ministério da Saúde" (art. 27, inciso II da Lei 6.360/76).

Atualmente, a maioria das solicitações de análise prévia visam a realização de testes exigidos para a análise de controle, ou seja, para o produto acabado e registrado. A análise prévia se transformou, apenas, na identificação e na quantificação de princípios ativos. Entretanto, esses testes não são suficientes para a avaliação da eficácia e da segurança do produto, que estão sendo julgadas no processo da concessão. Em outras palavras, o tipo de avaliação laboratorial que se vem reali- 
zando não fornece nenhuma informação adicional que ajude na tomada de decisão, nem tem qualquer vínculo com os objetivos desta etapa de fiscalização.

Em resumo, a análise prévia se aplica no momento de avaliação da concessão do registro onde, de direito, não existe o produto acabado e sim uma proposta tecnológica em estudo. Devem ser principalmente verificados, assim, os aspectos que interferem no binômio risco/benefício do novo produto. Ou seja, a análise prévia deve dar-se no momento em que se podem antever aspectos que venham a comprometer a "qualidade presumível" do novo produto.

Ao avaliar um pedido de registro, se persistirem dúvidas quanto à suficiência e/ou consistência das evidências científicas, a autoridade avaliadora deverá consultar o laboratório de referência. Mas sem esquecer que o responsável pelo produto é o fabricante, e que cabe a ele, e não ao Estado, providenciar novos estudos.

A prática tem demonstrado que está sendo chamada de análise prévia uma análise que a Legislação Sanitária define como análise de controle. Análise cujo momento, finalidade, procedimento e implicações são totalmente diferentes daquelas da análise prévia, e fundamentais para compor o conjunto de medidas da Vigilância Sanitária.

\section{Análise de controle}

\section{Definição}

A análise de controle de alimentos é definida no art. 2, inciso XVIII, do Decreto-Lei 986/69, como: "aquela que é efetuada imediatamente após o registro do alimento, quando da sua entrega ao consumo, e que servirá para comprovar a sua conformidade com o respectivo padrão de identidade e qualidade."

Para os outros produtos, o art. 3e, inciso XXX do Decreto 79.094/ 77 , que regulamenta a Lei $n \propto 6.360 / 76$, estabelece que a análise de controle: " é aquela efetuada em produtos sob o regime de Vigilância Sanitária, após sua entrega ao consumo e se destina a comprovar a conformidade do produto com a fórmula que deu origem ao registro."

\section{Outras disposições legais}

O art. 72 do Decreto-Lei n² 986/69, determina: "concedido o registro, fica obrigada a firma responsável a comunicar ao órgão competente, no prazo de até 30 (trinta) dias, a data da entrega dos alimentos ao consumo. 
\$1) Após o recebimento da comunicação, deverá a autoridade fiscalizadora competente providenciar a colheita de amostra para a respectiva análise de controle, que será efetuada no alimento tal como se apresenta ao consumo.

$\$ 2$ e) A análise de controle observará as normas estabelecidas para a análise fiscal.

\$3) O laudo de análise de controle será remetido ao órgão competente do Ministério da Saúde, para arquivamento, e passará a constituir o elemento de identificação do alimento.

\$49) Em caso de análise condenatória, e sendo o alimento considerado impróprio para o consumo, será cancelado o registro anteriormente concedido, e determinada a sua apreensão em todo território brasileiro.

\$5 ) No caso de constatação de falhas, erros ou irregularidades sanáveis, e sendo o alimento considerado próprio para o consumo, deverá o interessado ser notificado da ocorrência, concedendo-se o prazo necessário para a devida correção, decorrido o qual proceder-se-á a nova análise de controle. Persistindo as falhas, erros ou irregularidades ficará o infrator sujeito às penalidades cabíveis.

\$6) Qualquer modificação, que implique em alteração de identidade, qualidade, tipo ou marca do alimento já registrado, deverá ser previamente comunicada ao órgão competente do Ministério da Saúde, procedendo-se a nova análise de controle, podendo ser mantido o número de registro anteriormente concedido."

Já o Decreto 79.094/77, no art. 152, praticamente estabelece estes mesmos preceitos legais para os medicamentos, drogas, cosméticos, etc.

\section{Interpretação e comentários}

Cabe uma consideração preliminar sobre a clareza da legislação quanto ao momento, ao rito e às implicações da execução da análise de controle (caput do art. 72 e os parágrafos $12,2 \varrho$ e $4 \circ$ do Decreto-Lei 986/69, ou art. 153 do Decreto 79.094/77).

Os objetivos da análise de controle são:

1) Verificar se o produto que está entrando na cadeia de consumo, corresponde à composição e a todos os outros aspectos aprovados no ato da concessão do registro, como embalagem, rotulagem, etc.

2) Comprovar se o fabricante foi capaz de transferir o modelo tecnológico aprovado, no registro, ao produto acabado.

Só após a comprovação do cumprimento desses dois objetivos o ciclo do processo de concessão do registro se encerra. Ou seja, só após 
a realização da análise de controle o produto estaria finalmente aprovado para circular no mercado (\$3e do art. 7 e do Decreto-Lei 986/69), ou não $(\$ 4$ e). Isto é, o laudo analítico deverá classificar o produto como próprio ou impróprio para o consumo. E no primeiro caso, informará, ainda, se a liberação está condicionada a alguma correção quanto a

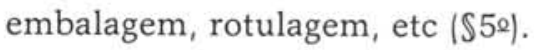

A Legislação determina o prazo para o fabricante comunicar à autoridade competente o local e a data do lançamento do produto no mercado (art. 152 do Decreto 79.094/77), sob pena de ter o registro cancelado ( $\$ 1$ do mesmo artigo e Decreto). Determina, ainda, a imediata coleta de amostras para a realização da análise de controle $(\mathbb{2} 2$ do mesmo artigo e Decreto).

A realização da análise de controle, pelo seu caráter eminentemente preventivo, incorpora objetivos adicionais, essenciais para a Saúde Pública, como a geração de informações e medidas legais, tais como:

1) Saneamento da oferta: sendo esta análise obrigatória para todos os produtos que estão sendo lançados no mercado, ou quando houver modificação na sua composição, a legislação busca assegurar a permanência no mercado apenas dos produtos que, ao menos, podem ser produzidos conforme o modelo aprovado no ato da concessão. Em outras palavras, ou o fabricante se mostra capaz de gerir o processo de produção e de fabricar o produto aprovado no registro, ou terá sua concessão cancelada imediatamente após o laudo condenatório.

De posse da informação da realização, ou não, da análise de controle, a Vigilância Sanitária poderá aplicar outro dispositivo, previsto nos incisos 12 e 8 e do artigo 12 da Lei n 6.360/76; segundo esses incisos não será revalidado o registro dos produtos que não forem fabricados nos primeiros cinco anos de vida após a concessão.

2) Conhecimento pleno da oferta do mercado: com a realização da análise de controle, a Vigilância Sanitária saberá quantos produtos estão no mercado, e quantos estão entrando em circulação.

Como sabemos, é comum a solicitação de registro de produtos para a posterior comercialização da própria concessão a outros interessados, sem que, no entanto, o produto chegue a ser produzido no prazo previsto em lei. Ocorre também que, após a concessão do registro, o fabricante desista da exploração comercial do produto, mas não comunique a desistência aos órgãos competentes.

Tais práticas são responsáveis pela grande discrepância entre o número de produtos registrados e os que estão sendo, efetivamente, comercializados. E gera incertezas quanto à real oferta de produtos no país; essa incerteza vai interferir na programação de ações de fiscalização e de controle. 
3) Acompanhamento epidemiológico: desde a informação do momento da entrada de um novo produto na cadeia de consumo, poderão ter início pesquisas epidemiológicas sobre os riscos decorrentes do uso, e sobre a eficácia, do produto. Essas pesquisas podem subsidiar ações preventivas, com o cancelamento dos que se mostraram produtos nocivos ou ineficazes, conforme estabelece art. 7 ㄹ da Lei 6.360/76. Entretanto, hoje em dia essas medidas ocorrem apenas após muitos anos de uso do produto.

A prática de monitoramento do uso dos novos produtos e insumos não tem sido sistemática, pois embora este tipo de ação já esteja prevista na legislação para os medicamentos, ainda é incipiente em nosso país. A princípio, toda substância nova (nova molécula ou nova indicação/aplicação) deve sofrer acompanhamento, baseado em métodos epidemiológicos, durante os primeiros anos de uso, seja o produto qual for.

Quando do lançamento de um novo filtro solar, por exemplo, seria necessário avaliar-lhe, ao menos, a eficiência na proteção contra os efeitos negativos dos raios solares e a manifestação de reações indesejadas. E qualquer irregularidade percebida implicaria a suspensão da produção dos filtros, até a elucidação dos fatos.

Pelo exposto, a análise de controle é fundamental para a composição do conjunto de ações da Vigilância Sanitária. Até o presente momento, porém, não existe explicação plausível para a sua não-aplicação. Um levantamento feito no Instituto Nacional de Controle de Qualidade em Saúde (INCQS/Fiocruz), revelou que esta modalidade não vem sendo praticada para a grande maioria dos produtos abrangidos pela Legislação Sanitária. Também se constatou que as análises ditas "de controle" referem-se a alguns alimentos importados. São análises lote a lote, o que é incorreto pois:

1) Quando o produto entra no país, pela primeira vez, deve-se fazer a análise de controle. E o produto reprovado não deve voltar a ser importado, como manda o ritual.

2) Qualquer outra apreensão do mesmo produto, na lógica da legislação vigente, chama-se análise fiscal, que tem objetivos e processamento legal diferentes, como veremos adiante.

3) Transformar a análise de controle em certificadora de lotes é um procedimento irracional, do ponto de vista da Saúde Pública, pois neutraliza o caráter saneador da análise de controle, e cria procedimentos diferentes para os produtos nacionais e os importados.

Urgem o resgate, o redimensionamento e a execução da análise de controle nas ações de Vigilância Sanitária, nos moldes previstos em lei. 
A análise de controle é fundamental para a Vigilância Sanitária, pois representa a certidão de nascimento do produto para o consumo, assim como a identidade analítica do mesmo.

A reprovação do produto obriga ao cancelamento do registro, e, por isso, essa não é uma análise de rotina. A análise de controle é obrigatória para o produto após a concessão, a modificação ou a revalidação do registro.

Pelos seus objetivos e implicações legais, a análise de controle é mais um elemento do conjunto de ações da Vigilância Sanitária, a garantir, juntamente com o ato de concessão do registro, a oferta de produtos de qualidade sanitária.

Infelizmente, esta modalidade de análise vem sendo ignorada pelo Ministério da Saúde, único órgão encarregado de conceder o registro, ou as modificações de fórmula, assim como a revalidação do produto. Urge o resgate da análise de controle como uma das ações fundamentais para a Saúde Pública.

Análise fiscal

1 Definições

O art. 2, inciso XIX do Decreto-Lei n 986/69 define análise fiscal como: "a efetuada sobre o alimento apreendido pela autoridade fiscalizadora competente e que servirá para verificar a sua conformidade com os dispositivos deste Decreto-Lei e de seus regulamentos."

Para os demais produtos, a definição de análise fiscal segue o art. 3e, inciso XXXI do Decreto 79.094/77: "a efetuada sobre os produtos submetidos ao sistema instituído por este Regulamento, em caráter de rotina, para apuração de infração ou verificação de ocorrência fortuita ou eventual."

\section{Outras disposições legais}

Tanto o Decreto-Lei ne 986/69 como a Lei n² 5.991/73, a Lei n² 6.360/ 76 e a Lei $n^{2} 6.437 / 77$ determinam que a ação de fiscalização seja rotineira. E submetem a apuração de infrações à apreensão de amostras, para a realização da análise fiscal.

Praticamente, quase todos os capítulos das leis sanitárias sobre fiscalização se referem a esta modalidade de análise, como veremos daqui para frente. As leis definem ainda, fraude, adulteração e produto impróprio para o uso. Como estaremos discutindo esses aspectos nas seções 
seguintes, não incluiremos aqui as outras disposições legais previstas para a análise fiscal.

3 Interpretação e comentários

A definição da análise fiscal já determina sua função nas ações de Vigilância Sanitária. Este tipo de análise comporá a rotina da fiscalização, e aqui reside o seu caráter programático, e os instrumentos para a elucidação das fontes de agravos, fortuitas ou eventuais, e do descumprimento da Legislação Sanitária.

Essa modalidade de análise é a que mais vem sendo praticada pelos fiscais e, talvez por isso, a que mais acumula vícios, tais como a superestimação da aplicação da mesma, em detrimento de ações mais eficazes e preventivas no ato de constatação de irregularidades, assim como a subutilização do laudo condenatório. Ou seja, a análise fiscal não tem servido para subsidiar as ações de superação do problema, ou de prevenção. Por outro lado, esta análise apresenta menos equívocos no momento de sua aplicação, do que a análise prévia e a análise de controle.

Pericia de contraprova

Admite-se a perícia de contraprova, embora não seja uma modalidade de análise, propriamente dita, como um desdobramento do laudo condenatório. Essa perícia estabelecida em lei e representa o direito de defesa que a Constituição Federal garante a qualquer um. Infelizmente, este direito vem sendo garantido de forma mecânica, e, assim, vem entrando em conflito com o direito à saúde da população, também garantido na Constituição.

\section{Definição}

A Legislação Sanitária não define, explicitamente, o que vem a ser uma perícia de contraprova. Esta perícia é entendida como a contestação, feita pelo infrator, ao discordar do resultado condenatório da análise de controle ou da análise fiscal.

O Dicionário Técnico Jurídico define contraprova como prova que é contraposta a outra, oferecida pela parte contrária em juízo.

\section{Outras disposições legais}

As disposições legais sobre esta questão aparecem em diversos parágrafos, do artigo 27 , da Lei n $6.437 / 77$, apresentados a seguir: "a 
apreensão do produto ou substância consistirá na colheita de amostra representativa do estoque existente, a qual, dividida em três partes, será tomada inviolável, para que se assegurem as características de conservação e autenticidade, sendo uma delas, entregue ao detentor ou responsável, a fim de servir como contraprova, e as duas outras imediatamente encaminhadas ao laboratório oficial, para realização das análises indispensáveis

\$3) Será lavrado laudo minucioso e conclusivo da análise fiscal, o qual será arquivado no laboratório oficial, e extraídas cópias, uma para integrar o processo e as demais para serem entregues ao detentor ou responsável pelo produto ou substância e à empresa fabricante.

$\$ 4$ e) O infrator, discordando do resultado condenatório da análise, poderá, em separado ou juntamente com o pedido de revisão da decisão recorrida, requerer perícia de contraprova, apresentando a amostra em seu poder e indicando seu próprio perito.

\$5) Da perícia de contraprova será lavrada ata circunstanciada, datada e assinada por todos os participantes, cuja primeira via integrará o processo, e conterá todos os quesitos formulados pelos peritos.

\$69) A perícia de contraprova não será efetuada se houver indícios de violação da amostra em poder do infrator e, nessa hipótese, prevalecerá como definitivo o laudo condenatório.

\$72) Aplicar-se-á na perícia de contraprova o mesmo método de análise empregado na análise fiscal condenatória, salvo se houver concordância dos peritos quanto à outro.

\$8) A discordância entre os resultados da análise fiscal condenatória e da perícia de contraprova ensejará recurso à autoridade superior no prazo de dez dias, o qual determinará novo exame pericial, a ser realizado na segunda amostra em poder do laboratório oficial."

\section{Interpretação e comentários}

A primeira questão latente na Perícia de Contraprova é que esta análise só deveria ser realizada quando, simultaneamente:

1) O resultado analítico da análise de controle ou da análise fiscal do produto o classificar como impróprio para o uso;

2) O infrator contestar o resultado da análise, e requerer, em tempo hábil (dez dias), a perícia de contraprova;

3) A autoridade competente julgar procedente as provas apresentadas pelo interessado, de contestação dos resultados (veracidade) do laudo de análise do laboratório de referência da Vigilância Sanitária.

Infelizmente, a autoridade competente não costuma entrar no mérito da contestação do infrator, e concede, de imediato, autorização 
para a realização da contraprova. Assim, esquece que o produto sob exame foi apreendido em virtude de alguma suspeita, e até de denúncia, por ela apurada.

Ademais, o laudo analítico é uma prova científica, que só pode ser contestada com evidências equivalentes, como, por exemplo, a apresentação de outros laudos. A prática tem demonstrado que a mera solicitação pelo infrator tem sido argumento suficiente para a concessão. O "ônus da prova", assim, tem recaído sobre a saúde da população.

Por outro lado, algumas questões devem ser levantadas, quanto às providências que o laudo condenatório desencadeia, independentemente da concessão, ou não, da perícia de contraprova, tais como:

- no caso de um laudo analítico condenatório de análise de controle, deveria iniciar-se o processo de cancelamento do registro, paralelo à interdição sumária do produto e da produção do mesmo. O mesmo é válido para os casos das análises fiscais relativas às denúncias graves, como por exemplo, de óbitos.

- todo e qualquer laudo que classificasse o produto como impróprio para o uso, deveria desencadear um processo de inspeção, desde a produção até à distribuição do produto, conforme o resultado analítico.

- na grande maioria dos casos, até o momento, os resultados encontrados na contraprova confirmam aqueles da análise fiscal, e assim demonstram a ausência de justificativa técnico-científico da solicitação da contraprova, e retardam a solução do problema.

Em resumo, instruída pela Lei $6.437 / 76$, a perícia de contraprova é a repetição da análise, que reprovou o produto, perante o perito da empresa interessada. A contraprova é um direito assegurado ao interessado, mas ele deverá fazer jus ao mesmo, deverá apresentar evidências científicas de que o laudo condenatório está equivocado. A autoridade competente deverá julgar a procedência do pedido de perícia de contraprova, lembrando que só se justifica sua concessão quando realmente o laudo oficial estiver sob suspeição. A autoridade deverá considerar, ainda, que qualquer delonga desnecessária à superação da fonte de agravo poderá trazer danos incalculáveis à saúde dos usuários.

Análise de desempate

Esta análise é um desdobramento da perícia de contraprova. E se dá quando a discordância entre os resultados da análise de controle ou fiscal condenatória e da perícia de contraprova enseja recurso à autoridade competente, a qual determinará novo exame pericial, a ser realizado na segunda amostra, em poder do laboratório oficial (art. 27, Lei $6.437 / 77)$. 


\section{Apreensão de amostras}

Na seção anterior apresentamos e discutimos as modalidades de análises previstas na Legislação Sanitária brasileira. Verificamos, também, serem claros os seus objetivos e os momentos de sua realização. Nesta seção serão apresentados e discutidos os pré-requisitos técnicos e legais, e os motivos para apreensão ou coleta de amostras, na perspectiva da abordagem laboratorial da Vigilância Sanitária.

Segundo o art. 68 da Lei n 6.360/76, a ação de fiscalização abrangerá todo e qualquer produto, inclusive os dispensados de registro, em todas as etapas do seu ciclo de vida, da produção ao comércio. Estabelece, ainda, que a ação deverá ser permanente, constituindo atividade rotineira dos órgãos de fiscalização (art. 70). Estas disposições determinam o caráter programático das ações de Vigilância Sanitária.

O controle pós-registro deve ser entendido como o conjunto de ações que a Vigilância Sanitária realiza para certificar-se de que o modelo tecnológico aprovado no registro foi incorporado ao produto final, no que se refere a matéria prima, produtos intermediários e acabados, embalagem, rotulagem, armazenagem, transporte, comercialização, propaganda e consumo. O controle destes aspectos irá contribuir para assegurar a qualidade presumida no registro. Logo, o objetivo da fiscalização é verificar, rotineiramente se as respectivas normas estão sendo cumpridas.

A apreensão de amostras não substitui a inspeção sanitária. A fiscalização é a atividade principal da Vigilância Sanitária (Lima et al., 1993); entre as trinta e uma infrações sanitárias (art. 10, Lei 6.437/77) apenas uma (inciso IV) admite apreensão de amostras (art. 23, Lei $6.437 / 77)$.

"A coleta de amostras para perícias técnica deve ser feita rigorosa e criteriosamente, como determina a Legislação, pois qualquer irregularidade no procedimento administrativo ou técnico invalida a medida adotada" (Lima et al., 1993).

Este é um cuidado que o agente fiscal deve sempre considerar, mesmo em apreensões programadas, ou seja, quando não existe suspeita aparente. Pois, na falta do respaldo legal, no caso de constatação de alguma irregularidade no produto as medidas corretivas terão que esperar nova apreensão e haverá retardamento na superação do problema.

Em resumo, as funções da apreensão de amostras, para as análises previstas em lei, são:

- concluir o ciclo de inspeção, e dar ênfase às provas;

- retroalimentar o processo de inspeção.

A "pior função" da apreensão é a de substituir a fiscalização! 
Termo de apreensão de amostra (TAA) ou termo

de coleta de amostras (TCA)

Em linguagem jurídica, não existe apreensão, sem o respectivo TAA, termo que vincula o produto ao processo administrativo para apuração de possíveis irregularidades. O TAA deve considerar ainda que "as infrações decorrentes de fraude, falsificação ou adulteração deverão ser declaradas explicitamente pelas autoridades sanitárias nos processos de apuração da infração, para possibilitar a caracterização de crime contra a Saúde Pública previsto no Código Penal..." (Lima et al., 1993).

Do ponto de vista da Saúde Pública, a menção dos motivos da apreensão é fundamental para orientar e diferenciar a abordagem laboratorial. Se durante uma inspeção numa planta fabril, ou do processo produtivo, o fiscal suspeitar de irregularidades em alguma etapa ou procedimento, ele deverá fazer a apreensão e relatar minuciosamente o observado. Neste caso, o laboratório deverá dar primazia aos testes capazes de elucidar o problema, para assim consubstanciar as medidas cabíveis em Lei, no sentido de sanar o problema e de criar condições para que não haja reincidência do mesmo. Nem sempre, no entanto, os testes preconizados nas farmacopéias permitem a elucidação, principalmente quando existe mudança de tecnologia no processo de obtenção da matéria prima, ou quando, ao contrário, se utilizam tecnologias arcaicas, que levam a contaminações não previstas da substância ou do produto em pauta.

No TAA ou no TCA não se precisa especificar o tipo de teste a ser solicitado (químico, físico-químico, microbiológico, etc), pois esse tipo de informação não elucida as questões em pauta. Além do mais, na divisão de trabalho das ações de Vigilância Sanitária, a determinação dos testes é de inteira responsabilidade dos laboratórios oficiais, instruídos pela Legislação Sanitária, como o veremos adiante.

O art. 12 da Lei ne 6.437/77, ao instruir a apuração de infrações à Legislação Sanitária, estabelece a apuração em processo administrativo próprio, iniciado com a lavratura de auto de infração, observados os ritos e prazos estabelecidos. A lavratura do auto que a lei determina para apreender amostras para a realização das análises previstas na legislação (controle ou fiscal), é um termo (de coleta ou apreensão) onde, além de se especificar ว motivo (rotina ou suspeita), descrever o produto, e o local da apreensão, se deverão relacionar os dispositivos legais ou regulamentares (lei, decreto, portaria, etc. e respectivo artigo) que tipificam a infração e fundamentam a ação. 
Boas Práticas

de Fabricação

\section{Apreensão programada}

É de praxe associar programas de fiscalização a apreensão de amostras. A apreensão se dá após uma inspeção a uma planta fabril, por exemplo, para se (com)provar se as normas de Boas Práticas de Fabricação (BPF) estão sendo devidamente aplicadas. As BPF são um conjunto de normas de especificação dos procedimentos de produção, que o fabricante deve cumprir para garantir produtos de boa qualidade. Essas normas abrangem todas as etapas de produção, estabelecem os controles necessários, como os laboratoriais, dos equipamentos, das embalagens e rotulagens, do armazenamento e da quarentena, da higiene e limpeza, etc. As normas dizem respeito, enfim, a todo e qualquer procedimento que possa interferir na qualidade final do produto.

Só após a comprovação da aplicação das BPF, deveriam ser apreendidas amostras de matérias primas e de produtos acabados. $\mathrm{O}$ objetivo da coleta de amostras, sob estas condições, é verificar outros aspectos, que o fiscal, a olho nu, não pode constatar, como se o fabricante está utilizando a matéria prima adequada, ou se o produto final incorporou a qualidade mínima exigida nas normas. Sem as BPF, de nada adianta apreender amostras, pois fontes de possíveis danos à saúde podem estar presentes, ou não, no lote apreendido.

A execução de análises laboratoriais decorrente das ações programadas não apresentam, a princípio, maiores problemas para a Vigilância Sanitária. Por serem programadas, são mais flexíveis quanto à quantidade de unidade amostral por lote. Os testes, por sua vez, podem ser escolhidos segundo o grau de complexidade da linha de produção ou da tecnologia utilizada; para os produtos injetáveis, por exemplo, o teste de esterilidade é fundamental; para os anticoncepcionais o teste para verificar a uniformidade de conteúdo dos comprimidos é fundamental.

Os programas de fiscalização do transporte, da distribuição ou do comércio também deveriam valer-se da apreensão de amostras, a fim de se verificar se algum fator, por exemplo, de clima ou de empilhamento, está interferindo na perda de qualidade do produto. Mas para essas coletas de amostras serem efetivas no diagnóstico da fonte de agravo, é preciso a produção seguir rigorosamente as BPF, para não se correr o risco de se mascarar a fonte do problema, e de se esvaziarem os objetivos do programa.

Os programas de apreensões devem ser detalhados em todos os aspectos, tais como: os objetivos que se pretende alcançar, os critérios da eleição dos produtos, os aspectos a serem avaliados e a necessidade, ou não, da participação de um laboratório oficial. Se houver essa neces- 
sidade, o laboratório oficial deverá estar presente na elaboração do programa, ajudando a definir o número de amostras, a quantidade amostral por lote e o plano de amostragem.

A participação do laboratório pode ser dispensada, por exemplo, no programa para verificar a aplicação da Denominação Comum Brasileira prevista no Decreto dos Genéricos, já que se avaliará a rotulagem dos produtos. Para se ter uma idéia das implicações de programas dessa natureza, em 1996 se realizou um estudo sobre as os dizeres das rotulagens dos fitoterápicos, e houve reprovação em $99 \%$ das apreensões efetuadas (Silva \& Carvalheiro, 1995).

Programas de apreensão possibilitam um diagnóstico de situação, e alimentam o caráter preventivo das ações de Vigilância Sanitária. Infelizmente ainda são incipientes as ações programadas de fiscalização, inclusive de apreensões previstas em lei, como as das análises de controle.

\section{Apreensão por denúncias}

A denúncia de possíveis irregularidades, feitas por usuários ou por profissionais de saúde, é uma importante fonte de informação para as autoridades da Vigilância Sanitária, pois, por mais bem estruturado que esteja o sistema, sempre haverá dúvidas quanto à qualidade dos produtos. A denúncia - ao acionar as autoridades para a tomada de providências - é um exercício do direito de cidadania.

Ao contrário do que vem ocorrendo, a apreensão por denúncia deve se restringir ao caráter eventual da ação de fiscalização. E não deve ser a única rotina dos órgãos de Vigilância Sanitária. O fato gerador da denúncia deve ser devidamente apurado pelo fiscal, para se verificar a procedência, ou não, da denúncia. Assim, se deverá resgatar o caráter investigador das ações de Vigilância Sanitária, e eliminar, definitivamente, apreensões mecânicas, destituídas dos objetivos sanitários.

Uma denúncia bem apurada, com relato circunstanciado, poderá permitir uma abordagem laboratorial incisiva sobre as possíveis fontes de agravos, e dará agilidade ao processo de elucidação dos fatos. Também poderá permitir uma investigação da relação de causalidade entre a fonte (produção, transporte, armazenamento do produto) e o evento identificado. E possibilitará a superação das fontes de agravos, assim como a correção de possíveis falhas nos instrumentos de fiscalização, como por exemplo, na norma de inspeção, no treinamento dos fiscais ou no método de análise oficial. Definições da quantidade de unidades amostrais e do número de amostras a serem apreendidas se relacionam com os fatos que se pretende elucidar. 
inversão do ônus da prova
Apreensão de produto com alteração

ou adulteração evidente

Produtos com alterações ou adulterações evidentes requerem respostas rápidas do sistema de Vigilância Sanitária, pois, como se desconhece a extensão do evento, enquanto o mesmo não for elucidado poderá haver danos incalculáveis para a saúde dos usuários. A contaminação microbiológica de um alimento, por exemplo, só se torna visível, aos olhos do usuário, na dependência de fatores como a temperatura e o tempo, entre outros. Mas o microorganismo continua latente, a espera, apenas, de condições ideais de crescimento, e a proliferação pode desencadear-se no organismo humano.

A legislação determina a obrigatoriedade da interdição cautelar, sempre que houver indícios evidentes de perigo iminente para a saúde (parágrafo $2 \varrho$ do art. 23 da Lei 6.437/77). Além da remessa da apreensão ao laboratório oficial, o agente deve acionar a Vigilância Sanitária do Estado em que se fabrica o produto, para rastrear, localizar e interditar o(s) lote(s) envolvido(s), assim como exigir, do fabricante, a elucidação da fonte do problema e a adoção das providências estabelecidas no Código de Defesa do Consumidor (recolher produtos defeituosos, alertar a comunidade, entre outras).

A seguir apresentaremos duas situações comuns neste tipo de irregularidade.

1) Algumas unidades, de um mesmo lote, apresentam um mesmo defeito: a elucidação desse tipo de problema vai além da avaliação analítica executada pelo laboratório oficial.

Em primeiro lugar porque as possíveis causas são inúmeras: falta de estabilidade do produto, defeitos, ou impropriedades, na embalagem, condições impróprias de transporte e/ou armazenamento, esses fatores associados, etc; a maior parte dessas averiguações escapam ao alcance do laboratório oficial, e exigem uma intervenção conjunta dos agentes fiscais e o produtor. Além disso, alguns dos testes realizados nos ensaios, como o da estabilidade do produto, em geral, demandam muito tempo e requerem uma grande quantidade de amostra, nem sempre disponível; e a solução do problema deve ser rápida.

Sendo assim, se a irregularidade constatada indica não estar o lote conforme a qualidade mínima exigida em lei, cabe ao fabricante esclarecer a origem da baixa qualidade do produto. Essa é a chamada inversão do ônus da prova, garantida pelo Código do Consumidor! O fabricante tem a obrigação de demonstrar, à Vigilância Sanitária que, não apenas detectou a(s) causa(s) da baixa qualidade do produto, mas a extensão do problema e, principalmente, que as falhas encontradas foram 
superadas. Em outras palavras, o fabricante tem de demonstrar que a produção voltou a ser digna da concessão de autorização de funcionamento, e que a fonte de agravo à saúde está superada. O papel do laboratório oficial, nestes casos, é o de, quando solicitado, ajudar na avaliação da documentação apresentada pelo fabricante, ou de analisar outros lotes.

2) Unidades de diferentes lotes apresentam o mesmo tipo de irregularidade: a questão é mais grave, pois compromete toda a linha de produção. Nestes casos, deverão ser acionados a Vigilância do Estado no qual está o fabricante e o Ministério da Saúde, para proceder à interdição da produção, a averiguação dos problemas e à revisão da concessão de registro, pelo menos no que se refere à estabilidade do produto.

Só após se constatar a superação de todas as fontes de agravos, devem ser apreendidas amostras para a realização de análises de controle, conforme se discutiu na seção anterior. Todos os informes sobre os fatos apurados devem ser encaminhados ao laboratório oficial que, neste caso, dará prioridade aos testes relacionados com a fonte de agravo, e realizará testes complementares, para verificar a capacidade de retomada da produção.

Os dois casos descritos requerem um bom entrosamento com o laboratório oficial de referência - os Laboratórios Centrais de Saúde Pública (LACENs), ou o INCQS. Pela natureza da irregularidade constatada, além da descrição minuciosa dos fatos, a apreensão deve ser realizada não em triplicata, como estabelece art. 27 da Lei $6.437 / 77$, e sim em apreensão única (parágrafo 1 do mesmo artigo e lei); nessa apreensão todas as unidades amostrais devem ser reunidas, incluindo as com evidentes problemas de qualidade, para, assim, ajudar nos estudos de probabilidade de possiveis causas.

Em resumo, a apreensão de amostra, para a realização das análises previstas em lei, é mais um elemento do conjunto de ações da Vigilância Sanitária. Para a apreensão poder cumprir seus objetivos, é necessário seguir critérios para a escolha do momento de realização da mesma, e haver rigor na aplicação da legislação.

Nesse sentido, o TAA, ou o TCA, além de representarem a lavratura do auto de fiscalização, são o elo de ligação entre a inspeção e a avaliação analítica. Desse elo dependerá o estabelecimento da relação de causalidade entre os fatos apurados (inspeção) e o evento identificado (avaliação analítica). Para tal, a descrição minuciosa das suspeitas da inspeção deve acompanhar as amostras apreendidas, e orientar a abordagem analítica, para a elucidação do problema, a cargo do laboratório oficial. 
Laboratório Oficial

\section{Avaliação analítica}

Na seção anterior se discutiu a apreensão como mais um elemento do conjunto de ações da fiscalização sanitária, e as implicações da mesma nas atividades de avaliação laboratorial da Vigilância Sanitária. Nesta seção discutiremos a função, o método e as peculariedades da avaliação analítica efetuada pelo Laboratório Oficial (L.O.).

O objetivo de qualquer ação de Vigilância Sanitária é verificar o cumprimento da legislação. Dito isto, a principal função da avaliação analítica efetuada por um L.O. é fornecer subsídios para a ação da fiscalização, no sentido de elucidar dúvidas quanto à qualidade mínima dos produtos sujeitos à Vigilância Sanitária.

Independente da modalidade de análise, e das causas que a motivaram, existe uma interface técnica entre a apreensão, ou coleta, de amostras e a abordagem analítica: o L.O. só poderá dirimir suspeitas efetivamente levantadas pela fiscalização. Se o termo de apreensão declara ser a apreensão uma análise de controle, o L.O. saberá exatamente que está sendo julgada a conformidade do produto com os termos concedidos no registro. Assim realizará todos os testes preconizados para $o$ produto, inclusive a análise de rotulagem, de embalagem, etc. $\mathrm{O}$ único pré-requisito técnico é a suficiência de unidades amostrais para a realização dos testes.

Em contrapartida, o mesmo não se pode dizer se o termo de apreensão simplesmente declara ser a análise uma análise fiscal. Se não houver nenhuma informação adicional no TAA, a abordagem laboratorial será mecânica, restringindo-se à verificação da conformidade. $\mathrm{E}$ nenhuma estratégia de investigação será acionada para dirimir suspeitas, caso existam.

\section{Monografia oficial}

O L.O. deve ater-se, estritamente, ao estabelecido em lei, como qualquer agente de Vigilância Sanitária. A Lei n² 6.360/76 determina "para efeito de fiscalização sanitária, os ensaios destinados à verificação da eficiência da fórmula serão realizados em consonância com as normas fixadas pelo Ministério da Saúde" (art. 73).

Já o art. 62, discrimina as diretrizes e a filosofia da fiscalização que os laboratórios da Vigilância Sanitária devem observar, ao classificarem como alterado, adulterado ou impróprio para o uso o medicamento, a droga e o insumo farmacêutico:

1) Que houver sido misturado ou acondicionado com substâncias que modifiquem seu valor terapêutico, ou a finalidade a que se destine; 
2) Quando houver sido retirado, ou falsificado, no todo ou em parte, elemento integrante de sua composição normal, ou substituído por outro de qualidade inferior, ou modificada a dosagem, ou lhe tiver sido acrescentada substância estranha à sua composição, de modo que esta se torne diferente da fórmula constante do registro;

3) Cujo volume não corresponder à quantidade aprovada;

4) Quando sua condição de pureza, qualidade e autenticidade não satisfizerem as exigências da Farmacopéia Brasileira, ou de outros códigos adotados pelo Ministério da Saúde.

Parágrafo único: ocorrendo alteração pela ação do tempo, ou causa estranha à responsabilidade do técnico, ou da empresa, fica esta obrigada a retirar imediatamente o produto do comércio, para correção ou substituição, sob pena de incorrer em infração sanitária.

Embora o art. 62 da Lei ne 6.360/76 seja específico para produtos farmacêuticos, os mesmos princípios praticamente se asseguram para os outros produtos de interesse da saúde.

$\mathrm{Na}$ ordem dos artigos, primeiro a Lei estabelece o que se considera "alterado, adulterado ou impróprio para o uso"; a seguir, determina como se efetuará a fiscalização, no L.O.: a avaliação analítica seguirá normas que estabelecem o limite da qualidade, fora do qual ficam comprometidos ou o binômio risco/benefício ou a qualidade presumida no registro.

Outra característica das normas é não retratarem o modelo ideal, mas o admissivel, negociado com as partes interessadas. Salvo exceção, as normas não estabelecem valores nominais, mas limites de tolerância, tendo, portanto, caráter de norma mínima.

As normas oficiais devem incorporar o padrão mínimo de qualidade, suficiente, no entender do Estado, para a aceitação do produto, tendo em vista as tecnologias de produção em uso no país. Em termos objetivos, a norma oficial representa o risco aceitável, num dado momento, e face ao conhecimento já acumulado, e incorpora o reconhecimento social do risco e a necessidade de controle do mesmo.

O conjunto de normas aplicadas, especificamente, à avaliação analítica chama-se Monografia Oficial (M.O.); o objetivo da mesma é estabelecer padrões para a tomada de decisão quanto à aceitação ou à recusa de produtos.

A M.O. estabelece os testes e especifica procedimentos, tipos e limites de contaminantes e os métodos de controle para qualquer um dos aspectos a comprometer a qualidade presumível do produto. As Monografias Oficiais devem refletir todas as situaçōes de riscos inerentes aos processos tecnológicos, abranger desde a síntese da matéria prima até os limitantes, e/ou condicionantes, da industrialização do produ- 
to. E especificar os testes para determinar a identidade, o teor, e a pureza da matéria prima e do produto acabado.

Uma outra característica da M.O. é ser específica para a substância, ou produto, a ser analisado, independentemente do fabricante. Deve, também, aplicar-se a qualquer tamanho amostral, independentemente de sua representatividade em relação ao tamanho do lote, graças ao princípio de independência do sistema de amostragem (Vernengo, 1992). Essa independência da amostra se deve ao princípio de que qualquer unidade do produto disponível no mercado deve estar contida nos limites estabelecidos pela M.O.

As características acima descritas elevam as M.O. ao status de Normas Positivas de Ordem Pública, que, em qualquer disputa legal, prevalecem! Em conseqüência, os Laboratórios Oficiais se vêem obrigados a aplicá-las na avaliação laboratorial das análises previstas nas leis, salvo nos casos de inexistência de norma específica e/ou nos de agravos inusitados à saúde.

Os fabricantes não são obrigados a utilizar os métodos analíticos descritos na M.O. para o controle de qualidade do seu produto. Sendo a Garantia da Qualidade de inteira responsabilidade do fabricante, ele poderá eleger qualquer sistema de controle, desde que observe os limites de tolerância estabelecidos nas normas.

Peculiaridades e limitantes da avaliação analítica

O alvo principal da avaliação laboratorial da Vigilância Sanitária é a realização de testes que se relacionam com a segurança dos produtos. Ou seja, é a verificação da presença de determinados contaminantes, ou sua quantificação, nos casos de limites preestabelecidos na Monografia Oficial. Os testes relacionados com a eficácia do produto, de um modo geral, se restringem à identificação e à quantificação da(s) substância(s) que, segundo se declara no registro, têm esta função.

A diferença entre a avaliação analítica da Vigilância Sanitária e o controle de qualidade da indústria começa pela definição legal. A seguir, vem a eleição do padrão que esta última irá assumir como filosofia de produção. Para melhor compreendermos esta afirmação alguns fatos são úteis:

1) $\mathrm{O}$ Inciso $\mathrm{XV}$, do art. 32 , da Lei $6.360 / 76$, define controle de qualidade como o "conjunto de medidas destinadas a garantir, a qualquer momento, a produção de lotes de medicamentos e demais produtos abrangidos por esta Lei que satisfaçam as normas de atividade, pureza, eficácia e inocuidade." 
Não é função do L.O. garantir a qualidade de qualquer linha de produção, ou realizar controle de qualidade; estas são funções do fabricante. Por isso, o termo mais apropriado para definir a função do L.O. não seria controle de qualidade, e sim avaliação da qualidade analítica, ou avaliação laboratorial, entendida como a que se deve efetuar para se assegurar a qualidade mínima de um produto.

2) Ao solicitar o registro do produto, o fabricante declara as quantidades de cada um dos componentes, apresenta estudos que demonstrem serem as mesmas suficientes para assegurarem a eficácia demonstrada e apresenta as reações adversas associadas a estas quantidades.

A M.O. determina, por sua vez, os limites mínimos, fora dos quais a relação risco/benefício aprovada fica comprometida. O critério a nortear a escolha de cada um dos limites é a viabilidade, em se considerando as tecnologias à disposição, no país, e o fator de variação do processo produtivo. Por isso os limites não são nominais e, sim, limites de tolerância. E podem variar, por exemplo, de $90 \%$ a $115 \%$ do valor declarado!

3) Para o fabricante, essa variação representa o limite que seu produto acabado tem que respeitar. Ele pode estabelecer, por exemplo, que o padrão do seu produto é $100 \%$ e, que a variação do seu processo produtivo será de mais ou menos $2 \%$, e, ainda, que qualquer lote a não atender esta meta será descartado ou reprocessado. Esta é uma meta completamente viável e que só depende da tecnologia utilizada e dos cuidados necessários a seu cumprimento.

O fabricante idôneo não vai admitir liberar um lote que sai da linha de produção com o teor próximo a um dos limites extremos, tendo em vista que esse limite deverá manter-se estável até o último dia do prazo de validade.

Como o produtor dispõe de todos os dados sobre a produção, pode elevar, ao máximo, seus parâmetros de controle, baseando-se em planos de amostragem estatísticos, nas Boas Práticas de Produção e na validação de todas as etapas do processo produtivo (Ministério da Saúde, 1994). O respeito a esses parâmetros irá garantir a produção de lotes homogêneos e, assim, o cumprimento das metas estabelecidas pela filosofia de qualidade adotada pela empresa. Existem inúmeras técnicas disponiveis para se alcançar esta meta.

Quando uma apreensão entra no L.O., são várias as incógnitas de difícil elucidação. Desconhece-se o processo de síntese da matéria prima utilizada e se supõe que a mesma tenha a qualidade estabelecida na M.O., fundamental para a qualidade do produto final. Em geral não se repetem, no produto acabado, os testes de contaminantes previstos para a matéria prima, por exemplo. Segue-se o princípio de ser homogêneo o 
lote apreendido, embora o uso equivocado do conceito de lote invalide este princípio (Marques, 1992). E tantos outros questionamentos reiteram a premissa mencionada na seção anterior: ou se assegura o cumprimento das BNF, ou a capacidade de detecção de possíveis fontes de agravos à saúde, através da apreensão de amostra, torna-se casual.

Pelo acima exposto, e considerando-se as questões apresentadas nas seções anteriores, os objetivos dos L.O. se diferenciam, em muitos aspectos, dos laboratórios de controle de qualidade de qualquer linha de produção, embora técnicas e métodos utilizados sejam praticamente os mesmos. Isto porque:

1) Independentemente do universo amostral apreendido, o laudo analítico do L.O. representa uma fotografia instantânea do produto ao chegar ao consumidor, mostra se o produto preenche, ou não, as características mínimas de qualidade estabelecidas na Legislação Sanitária.

2) Esta fotografia deverá informar à Vigilância Sanitária da necessidade, ou não, de intervenção na fonte de agravo. Independentemente dos motivos da apreensão, o laudo oficial assinala uma irregularidade, que precisa ser superada.

As normas referidas não são estáticas e vêm sofrendo sucessivas revisões, na busca de acompanhar o conhecimento científico do risco e o desenvolvimento tecnológico da produção. Falta, na Legislação Sanitária, explicitar que, na ausência de um teste específico para elucidação de agravos à saúde, prevalecerão os últimos conhecimentos científicos sobre o assunto. Tal dispositivo legal faz-se necessário devido ao grande número de eventos nocivos que não constam e que, em alguns casos específicos, não deveriam constar nas M.O., uma vez que são conhecimentos e técnicas, básicos, de domínio das tecnologias de produção. Também é importante a existência de uma defasagem muito grande entre as descobertas científicas e a elaboração de normas legais, estas últimas dependem de negociações políticas, e só absorvem o conhecimento científico muito tempo depois.

Recentemente, por exemplo, uma suspensão injetável foi apreendida por estar causando abscesso estéril em vários usuários, além de entupimento da agulha, entupimento que obrigava a se espetar os pacientes mais de uma vez. Após estudo exaustivo, se constatou irregularidade na granulometria do pó do injetável, bem acima das especificaçōes dos livros especializados, inclusive nas descrições, no capítulo de generalidades, da Farmacopéia Brasileira, 4a Edição. Após a associação do agravo à saúde com o tamanho das partículas em suspensão, a Comissão de Revisão Permanente da Farmacopéia brasileira achou por bem suprimir esta especificação, sob a alegação de que nenhuma outra farmacopéia determinava tal limite. A comissão esqueceu assim, que as 
farmacopéias nacionais devem refletir o estágio de desenvolvimento tecnológico e industrial do país, ou não têm sentido de existir! Mais uma vez, o ônus da prova recaiu sobre a saúde da população. Por outro lado, a comissão estabeleceu que a partir de agora as suspensões nacionais ou importadas podem ter o tamanho de partícula que os fabricantes decidirem.

Se existe alguma suspeita, a Lei n 6.360/76 exige a apuração exaustiva das possiveis fontes causadoras do dano. É o caso da "verificação de ocorrência fortuita ou eventual", a que se refere a definição legal da Análise Fiscal (inciso XXXI do art. 3e do Decreto 79.094/77). Nunca é demais lembrar que os artigos 6 e e 7 이 Lei n 6.360/76, estabelecem: "a comprovação que determinado produto, até então considerado útil, é nocivo á saúde, ou não preenche requisitos estabelecidos na lei implica na sua imediata retirada do mercado." (art. 60). "Como medida de segurança sanitária e à vista de razões fundamentadas do órgão competente, poderá o Ministério da Saúde, a qualquer momento, suspender a fabricação e venda de qualquer produto de que trata esta Lei, que embora registrado, se torne suspeito de ter efeitos nocivos à saúde humana." (art. 7)

A avaliação analítica efetuada pelo Laboratório Oficial, tal como regulamentada pela Legislação Sanitária, reflete a "percepção" estatal do risco à saúde. E se materializa em normas jurídicas, a serem observadas pelo setor fabril, e fiscalizadas pelos laboratórios da Vigilância Sanitária.

Em outras palavras, ao setor privado tudo é permitido, desde que as normas jurídicas nada digam em contrário; cabe ao setor privado observar a Lei. Em contrapartida, ao setor público, cabe a estrita aplicação da Lei. E quando esta se revela insuficiente para proteger a saúde da população, cabe-lhe propor a modificação, ou a criação de novas normas legais, embasadas nas identificações das novas fontes de agravos à saúde. Daí resulta a necessidade de avaliação permanente e contínua.

A interpretação da Legislação Sanitária em vigor nos leva a concluir que a Monografia Oficial, além de ser considerada o padrão mínimo de qualidade para a aceitação do produto no mercado, objetiva assegurar a eficácia e a segurança do mesmo. Assim, os testes descritos na M.O., deverão ser realizados a qualquer momento (caráter rotineiro da análise fiscal), sem prejuízo de outros testes que o laboratório julgue necessário para elucidar denúncias de sinistros, ou qualquer outra irregularidade.

"A característica fundamental das atividades do laboratório de Saúde Pública é contribuir para o estudo das soluções pertinentes aos principais agravos que comprometem a manutenção da Saúde do cidadão. 
Para tanto, deve alimentar o Sistema de Saúde com as informações necessárias para a adequada tomada de decisão quanto às medidas de Controle a serem adotadas pela Sociedade e seus órgãos envolvidos com a preservação das condições globais do bem-estar da Coletividade" (Moura, 1992).

\section{Referências bibliográficas básicas}

BRASIL, 1929. Introdução da Farmacopéia Brasileira. 4a Edição.

EDUARDO, Maria Bernadete de Paula, 1998. Vigilância Sanitária. V. 8., São Paulo: Faculdade de Saúde Pública da Universidade de São Paulo.

LIMA, Luis Felipe Moreira et all., 1993. Vigilância Sanitária de medicamentos e correlatos. Rio de Janeiro: Qualitymark.

MARQUES, Luis Carlos., 1992. Produçâo e Comercialização de Fitoterápicos no Paraná: uma Abordagem de Vigilância Sanitária. [Tese - Universidade Federal do Paraná, Setor de Ciências Biológicas. Paraná.]

MINISTÉRIO DA SAÚDE, SECRETARIA DE VIGILÂNCIA SANITÁRIA, 1994. Boas práticas para a fabricação de produtos farmacêuticos: Comitê de peritos da OMS em especificaçōes para preparados farmacêuticos - trigésimo segundo relatório/Traduçāo de Janil Elias Sultanus Cordeiro e Maria Gisela Piros, Brasília.

MINISTÉRIO DA SAÚDE., 1998. Manual de Coleta de Amostras de Produtos Sujeitos a Vigilância Sanitária. Rio deJaneiro: INCQS/Fiocruz.

MOURA, Anísio de, 1992. Perspectivas do IAL enquanto Laboratório de Saúde Pública. Prefácio In: Instituto Adolfo Lutz - 100 anos de Laboratório de Saúde. Org. ANTUNES, José Leopoldo Ferreira; NASCIMENTO, Claudia Barleta; NASSI, Lúcia Castilho; PREGNOLATTO, Neus Pascvet. São Paulo: Editora Letras \& Letras.

OMS, OPAS, 1989. Pauta para el estabelecimento de un programa nacional de control de medicamentos. Guatemala.

OMS, 1990. Comité de expertos de la OMS en especificaciones para las preparaciones farmacéuticas. Serie de Informes Técnicos. 312 (790):34-51.

PILATI, J.I., 1995. A Lei n 8.080/90 e a Vigilância Sanitária: Um estudo descritivo. [Tese de Doutorado - Universidade Federal de Santa Catarina/Centro de Ciências Jurídicas. Santa Catarina].

SILVA, De Plácido, 1998. Vocabulário Jurídico. Rio de Janeiro: Companhia Editora Forense.

SILVA, Ana Celia Pessoa da \& CARVALHEIRO, M.V.S., 1995. Consumo de produtos "naturais": Um problema de saúde pública. Anais do III Congresso Brasileiro de Vigilância de Medicamentos. São Paulo.

VERNENGO, M.J., 1994. Utilizacion de las normas farmacopeicas en el control de los medicamentos. Buenos Aires. (mimeo).

\section{Legislação básica}

DECRETO LEI ne 986 de 21 de outubro de 1969: institui normas básicas sobre alimentos. LEI n² 6.360, de 23 de setembro de 1976, dispōe sobre a Vigilância Sanitária a que ficam sujeitos os medicamentos, as drogas, os insumos farmacêuticos e correlatos, cosmé. ticos saneantes e outros produtos, e dá outras providências. 
LEI n² 6.437, de 20 e agosto de 1977: configura infraçōes à Legislação Sanitária Federal, estabelece as sançōes respectivas, e dá cutras providências.

DECRETO n 79.094 de 5 de janeiro de 1977: :egulamenta a Lei n 6.360 de 23 de setembro de 1976, que submete, ao Sistema cie Vigilância Sanitária, os medicamentos, insumos farmacêuticos, drogas correlatos, cosméticos, produtos de higiene, saneantes e outros.

PORTARIA MS/Bsb ne 399, de 6 de dezembro de 1997: normatiza as atribuiçōes das autoridades sanitárias competentes, na aplicação da Legislação Sanitária e, especialmente da Lei n²6.437/77. 



\section{formato}

$20 \times 25 \mathrm{~cm}$

\section{tipografias}

Garth Graphic e Frutiger Condensed

\section{papéis}

miolo Print Max 90g/m²

capa Cartão Supremo $250 \mathrm{~g} / \mathrm{m}^{2}$

\section{reimpressão e acabamento}

Imprinta Express Gráfica e Editora Ltda.

Rio de Janeiro, outubro de 2009.

Não encontrando nossos títulos em livrarias, contactar a Editora Fiocruz:

Av. Brasil, 4036, $1^{\circ}$ andar, sala 112, Manguinhos

21040-361, Rio de Janeiro, RJ

Tel.: (21) 3882-9039 e 3882-9007

Telefax: (21) 3882-9006

www. fiocruz.br/editora

e-mail: editora@fiocruz.br 
